\title{
Integrated coastal
}

management law

Establishing and strengthening national legal frameworks for integrated coastal management 


\section{FOREWORD}

More than a decade ago the Food and Agriculture Organization of the United Nations (FAO) published Legal and Institutional Aspects of Integrated Coastal Area Management in National Legislation ${ }^{1}$. The preface to that publication pointed out that integrated coastal area management law was a relatively new the field and that few jurisdictions had comprehensive legal frameworks to promote integrated coastal management. The situation has changed dramatically since then. Integrated coastal management (ICM) is now widely accepted throughout the world as the best approach to dealing with coastal issues and the 1990s saw a proliferation of legislative reform processes throughout the world aimed at supporting the implementation of ICM. This trend remains strong and many countries, including most of the Member States of the European Union, are in the process of strengthening the legislative basis for ICM.

The urgency of addressing coastal issues is now considerably greater than it was a decade ago. Despite many international environmental treaties, declarations and other promises of action, the quality of coastal environments continues to deteriorate in most of the world. Many of the major pressures on coastal areas in the early 1990s have continued to intensify. Coastal fisheries in much of the world have continued to decline rapidly while the demand for coastal resources and the pollution of coastal waters has increased in most areas due to a variety of factors including increases in coastal populations.

The full implications of other threats are only now becoming apparent or being appreciated fully. These include the risk arising from the transfer of pathogens and aquatic organisms in ships' ballast water, and the effects of climate change. Sea levels are rising and in many parts of the world disruptions of weather patterns are apparent in the increased frequency and intensity of storms. As a result, coastal erosion and flooding has increased, threatening coastal human populations and the natural environment.

On the positive side, it is clear that globally there is now a far greater appreciation of the environmental, economic, social, cultural and recreational importance of coastal areas, and of the value of ICM. Indeed there is now

1 Boelaert-Suominen, S. and Cullinan, C., 1994. Legal and institutional aspects of integrated coastal area management in national legislation, FAO Legal Office, Rome, 118 pp. 
effectively a world-wide consensus that ICM is significantly better than more traditional sectoral approaches to managing human activities within coastal areas. A number of international and regional institutions have developed guidelines on integrated coastal management including the OECD (1991), the World Coast Conference (1993), the World Bank (1993), the IUCN (Pernetta and Elder, 1993), the United Nations Environment Programme (1995) and the European Union. (A synthesis of the core elements which are common to the various ICM guidelines is set out in Box 2).

Another positive development has been a perceptible shift toward acknowledging the paramount importance of maintaining the ecological integrity of the coast. If human activities are not managed to ensure that this ecological integrity is maintained and - where necessary - restored, the productivity and health of the coasts and of the people and other species that live along it will be impaired, and future generations will be impoverished. This shift is reflected, for example, in the development of the so-called "ecosystem approach" by the Conference of the Parties to the Convention on Biological Diversity ${ }^{2}$ and its subsequent adoption in other international and regional instruments (see the discussion in section 2.2). One implication is that coastal management laws must be designed to manage humans to ensure that their impacts on coastal areas must respect certain natural limits. Although this may seem obvious to many people, much of the literature on coastal management still displays a failure to appreciate that the focus of coastal management ought to be on managing people and their impacts on the coastal environment and one another, rather than on managing the environment itself.

Over the last decade FAO has continued to play an important role in supporting the development and implementation of ICM throughout the world, in support of Agenda 21, Chapter 17, Programme Area A, "Integrated Management and Sustainable Development of Coastal and Marine Areas, including Exclusive Economic Zones". In 1992 FAO published "Integrated Management of Coastal Zones"3 and in 1998, published "Integrated Coastal Area Management and Agriculture, Forestry and Fisheries", FAO Guidelines. ${ }^{4}$ In addition FAO has promoted ICM in a variety of other

2 See Decision V/6 adopted at the Fifth Conference of the Parties, May 2000.

3 FAO Fisheries Technical Paper No. 327.

4 FAO, 1998. 
publications including: "The Code of Conduct for Responsible Fisheries" and the various guidelines published in support of the Code, such as "Integration of Fisheries into Coastal Area Management".

Since the 1994 publication of "Legal and Institutional Aspects of Integrated Coastal Area Management in National Legislation" the volume of information available through the internet on coastal management initiatives and ICM laws world-wide, has increased exponentially. New technologies of the information age have also had a significant impact on coastal management. For example, technologies such as geographical information systems (GIS) and vessel monitoring systems (VMS) for the remote monitoring of fishing vessels have meant that considerably more information regarding human uses of the coastal environment is available, or potentially available, to both regulators and user of the coast. This has created both a need for more sophisticated information management systems and opportunities for innovative regulatory approaches.

Sincere gratitude must be extended to Cormac Cullinan for his original transcript. Cormac Cullinan and the FAO Development Law Service are indebted to Ariella D'Andrea, FAO Legal Consultant, who assisted through conducting research in Rome for this publication. She did an excellent job of locating useful materials and gathering information from countries. Deep appreciation goes to Lawrence Christy and Robert Daley who kindly researched, updated and edited the final transcript.

Stefano Burchi

Officer-in-Charge

Development Law Service 


\section{USERS' GUIDE}

This publication is intended to assist anyone involved in the development or implementation of a legal or institutional framework to promote integrated coastal management (ICM). It includes revised versions of some of the information contained in the 1994 FAO publication "Legal and Institutional Aspects of Integrated Coastal Area Management in National Legislation" and the 1998 FAO Publication "Integrated Coastal Area Management and Agriculture, Forestry and Fisheries", FAO Guidelines. However the focus of this publication is on identifying and providing practical guidance on how to deal with typical issues that arise in the development, drafting and implementation of ICM legislation. In doing so it draws upon the experiences of a range of countries throughout the world which are at various stages of developing and implementing legislation to promote ICM.

There are three Parts to the publication. The first Part (chapters 1-3) provides an overview of the subject and sets out the context within which national ICM laws must be developed. Chapter 1 explains fundamental concepts and identifies the key pressures on coastal ecosystems, their social and environmental impacts and some of the legal responses at the international, regional and national levels. Chapter 2 explains the general and legal principles on which ICM is based, while chapter 3 discusses relevant international law and guidelines and other policy documents relevant to the development of national legal frameworks for ICM.

The second Part (chapters 4 and 5) discusses the process of developing a legal framework for ICM and draws attention to the key issues that must be taken into consideration at the outset.

The third Part (chapters 6-12) focuses on the different legal approaches and techniques that can be used to achieve different ICM objectives. It gives an indication of the different ways in which countries have approached ICM (chapter 6 ) and also discusses some of the legal aspects of institutional structuring that are so important in ensuring that ICM programmes are implemented effectively (chapter 12).

The final Part (chapter 13) looks at the global development of ICM. In particular it discusses trends in ICM legislation over the last decade and speculates as to how this field is likely to develop in future.

The text is supplemented by a number of boxes (listed on the next page) which contain illustrative examples drawn from the experience of a particular country or region, or tables intended to provide an accessible overview of an issue or the relationship between different factors. 


\section{BOXES}

Box 1 Some definitions of integrated coastal management 5

Box 2 A consensus set of integrated coastal management guidelines ............ 11

Box 3 Overview of coastal pressures and impacts and examples of global, regional and national legal responses

Box 4 European Union Recommendation concerning the implementation of Integrated Coastal Zone Management in Europe ............................................................................................. 31

Box 5 Treaties relevant to key ICM issues ..................................................... 42

Box 6 A selection of regional treaties relevant to ICM .................................. 45

Box $7 \quad$ How integrated is the legal framework itself? ....................................... 76

Box 8 Issues in evaluating legal frameworks for ICM .................................. 77

Box 9 Coastal characteristics and legislative design implications .................... 80

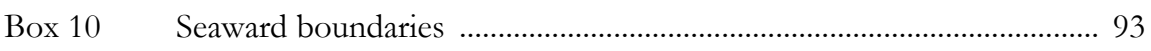

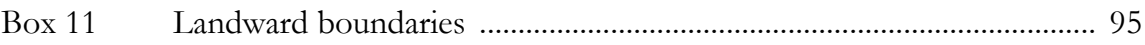

Box 12 U.S. Federal Requirements for State Coastal Management Programmes ................................................................... 113

Box 13 Extracts from the Swedish Environmental Code, 1998 ..................... 120

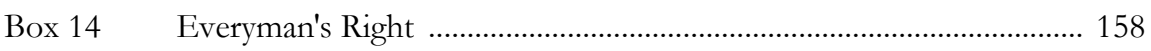

Box 15 The legal status of the coast in South Africa ...................................... 161

Box 16 Coastal Zoning categories and restrictions in India ........................... 188

Box 17 Criteria used to determine setback lines in Western Australia ........... 192

Box 18 Examples of coastal activities in respect of which EIAs are required ................................................................ 203

Box 19 Factors affecting compliance with laws ............................................... 215 


\section{TREATIES AND INSTRUMENTS}

1954 International Convention for the Prevention of Pollution of the Sea by Oil (London), 327 UNTS 3; UKTS 54 (1958), Cmnd. 595; 12 UST 2989, TLAS 4900. In force on 26 July 1958. Amended 1962 and 1969. Antarctic Treaty. In force on 23 June 1961; Protocol of 1991, q.v.

1968 African Convention on the Conservation of Nature and Natural Resources (Algiers), 1001 UNTS 4. In force on 16 June 1969. Replaced by 2003 Maputo Convention, q.v.

International Convention on Civil Liability for Oil Pollution Damage (Brussels), 973 UNTS 3; UKTS 106 (1975), Cmnd. 6183; 9 ILM (1970), 45. In force on 19 June 1975, 1976 Protocol, UKTS 26 (1981), Cmnd. 8238; 16 ILM (1977), 617. In force on 8 April 1981. Replaced by 1992 Convention q.v.

1969 International Convention Relating to Intervention on the High Seas in Cases of Oil Pollution Damage (Brussels), UKTS 77 (1971), Cmnd. 6056; 9 ILM (1970), 25. In force 6 May 1975. 1973 Protocol UKTS 27 (1983), Cmnd. 8924; 68 AJIL (1974), 577. In force on 30 March 1983.

1971 Convention on Wetlands of International Importance (Ramsar), 996 UNTS 245; UKTS 34 (1976), Cmnd. 6465; 11 ILM (1972), 963. In force on 21 December 1975. Amended 1982 and 1987, repr. in B\&B Docs, 447, in force 1 May 1994.

1971 Convention on the Establishment of an International Fund for Compensation for Oil Pollution Damage (Brussels). UKTS 95 (1978), Cmnd. 7383; 11 ILM (1972), 284. In force on 16 October 1978. Replaced by 1992 Convention q.v.

1972 Declaration of the United Nations Conference on the Human Environment (Stockholm), UN Doc. A/CONF/48/14/REV.1; B\&̈B Docs, 1.

1972 UNESCO Convention concerning the Protection of the World Cultural and Natural Heritage, UKTS 2 (1985), CMND. 9424; 27 UST 37, TLAS 8225; 11 ILM (1972), 1358; B\&B Docs, 375. In force on 17 December 1975.

1972 Convention on the Prevention of Marine Pollution by Dumping of Wastes and other Matter (London), 26 UST 2403, TLAS 8165; UKTS 43 (1976), Cmnd. 6486; 11 ILM (1972), 1294; B\&B Docs, 174. In force on 30 August 1975. To be replaced by 1996 Protocol q.v. 
Convention on International Trade in Endangered Species of Wild Fauna and Flora (Washington), 993 UNTS 243; UKTS 101 (1976), Cmnd. 6647; 12 IL M 1085 (1973); B\&\&B Docs, 415. In force on 1 July 1975.

1974 Nordic Convention on the Protection of the Environment (Stockholm), 13 ILM (1974), 511. In force on 5 October 1976.

1974 Convention on the Protection of the Marine Environment of the Baltic Sea Area (Helsinki), 13 ILM 546 (1974), 546. In force on 3 May 1980. Replaced by 1992 Helsinki Convention q.v.

1974 Convention for the Prevention of Marine Pollution from Land-Based Sources (Paris), UKTS 64 (1978), Cmnd. 7251; 13 ILM 352 (1974), 352. In force on 6 May 1978. Amended by Protocol of 1986, 27 ILM (1988), 625, in force on 1 February 1990. Replaced by 1992 Paris Convention q.v.

1976 Convention for the Protection of the Mediterranean Sea Against Pollution (Barcelona); Protocol concerning Cooperation in Combating Pollution of the Mediterranean Sea by Oil and Other Harmful Substances in Cases of Emergency; Protocol for the Prevention of Pollution of the Mediterranean Sea by Dumping from Ships and Aircraft, $15 \operatorname{ILM}$ (1976), 290. All in force on 12 February 1978. 1980 and 1982 Protocols (q.v.). Revised Convention and Protocols 1995/6 q.v.

1978 Protocol Relating to the Convention for the Prevention of Pollution from Ships (MARPOL), 17 ILM (1978), 546; B\&B Docs, 189. In force on 2 Otober 1983. Annexes I-III, and V in force. Annexes III and VI not in force. Current texts in IMO, MARPOL Consolidated Edition.

1978 Regional Convention for Cooperation on the Protection of the Marine Environment from Pollution (Kuwait), 1140 UNTS 133; 17 ILM (1978), 511; Protocol concerning Regional Cooperation in Combating Pollution by Oil and other Harmful Substances in Case of Emergency. Both in force on 1 July 1979. Protocols 1989, 1990 and 1998 (q.v.).

1978 UNEP Principles on Conservation and Harmonious Utilization of Natural Resources Shared by Two or More States, 17 ILM (1978), 1094; B\&B Docs, 21.

1979 Convention on the Conservation of Migratory Species of Wild Animals (Bonn), 19 ILM (1980), 15 B\&B Docs, 433. In force on 1 November 1983.

1979 Convention on the Conservation of European Wildlife and Natural Habitats (Berne), UKTS 56 (1982), Cmnd. 8738; ETS 104; B\&B Docs, 455. In force on 1 June 1982. 
Protocol for the Protection of the Mediterranean Sea Against Pollution from Land-Based Sources (Athens), 19 ILM (1980), 869. In force on 17 June 1983.

1980 Convention on the Conservation of Antarctic Marine Living Resources (Canberra), UKTS 48 (1982), CMND, 8714; TLAS 10240; 19 ILM (1980), 837; B\&B Docs, 628. In force on 7 April 1982.

1981 Agreement on Regional Co-operation in Combating Pollution of the South-East Pacific by Hydrocarbons or Other Harmful Substances in Cases of Emergency (Lima). In force on 14 July 1986. Supplemented by Protocol of 1983, q.v.

1981 Convention and Protocol for Cooperation in the Protection and Development of the Marine and Coastal Environment of the West and Central African (Abidjan) and Protocol concerning Co-operation in Combating Pollution in Cases of Emergency, 20 ILM (1981), 746. In force on 5 August 1984.

1981 Convention for the Protection of the Marine Environment and Coastal Area of the South-East Pacific (Lima), ND (Looseleaf), Doc. J. 18. In force on 19 May 1986.

1982 Regional Convention for the Conservation of the Red Sea and Gulf of Aden Environment (Jeddah), and Protocol concerning Regional Co-operation in Combating Pollution by Oil and Other Harmful Substances in Cases of Emergency, 9 EPL 56 (1982). All in force on 20 August 1985.

1982 Protocol concerning Mediterranean Specially Protected Areas (Geneva), ND (Looseleaf) Doc. J.20. In force on 23 March 1986. (Replaced by 1996 Protocol q.v.)

1982 UN Convention on the Law of the Sea (Montego Bay), Misc. 11 (1983), Cmnd 8941; 21 ILM (1982), 1261. In force on 16 November 1994.

1983 Convention for the Protection and Development of the Marine Environment of the Wider Caribbean Region (Cartegena de Indias) and Protocol concerning Co-operation in Combating Oil Spills in the Wider Caribbean Region, 22 ILM (1983), 221; UKTS 38 (1988), Cm 399. In force on 11 October 1986. (1990 Protocol q.v.)

1983 Protocol for the Protection of the South-East Pacific Against Pollution from Land-Based Sources (Quito): Burbenne, 983:53. In force on 23 September 1986.

1983 Supplementary Protocol to the Agreement on Regional Co-operation in Combating Pollution of the South-East Pacific by Hydrocarbons or other Harmful Substances (Quito). In force on 20 May 1987. 
Convention for the Protection, Management and Development of the Marine and Coastal Environment of the Eastern African Region (Nairobi); Protocol concerning Protected Areas and Wild Flora and Fauna in the Eastern African Region; Protocol concerning Cooperation in Combating Marine Pollution in Cases of Emergency in the Eastern African Region, Burhenne, 385:46; ND (Looseleaf) Doc. J.26. In force on 30 May 1996.

1986 Convention for the Protection of the Natural Resources and Environment of the South Pacific Region by Dumping; and Protocol concerning Co-operation in Combating Pollution Emergencies in the South Pacific Region (Noumea), 26 ILM (1987), 38. In force on 18 August 1990.

1989 ILO Convention No. 169 concerning Indigenous and Tribal Peoples in Independent Countries, 72 ILO Off. Bull. 59 (1989); 28 ILM (1989), 1382. In force on 5 September 1991.

1989 Protocol concerning Marine Pollution Resulting from Exploration And Exploitation Of The Continental Shelf (Kuwait). In force on 17 February 1990.

1989 Protocol for the Conservation and Management of Protected Marine and Coastal Areas of the South-East Pacific (Paipa), ND (Looseleaf), Doc.J. 35. In force on 17 October 1994.

1989 Protocol for the Protection of the South-East Pacific Against Radioactive Pollution. In force on 7 February 2000.

1990 Protocol concerning Specially Protected Areas and Wildlife in the Wider Caribbean (Kingston). 19 EPL (1989), 224, Burhenne 990:85. In force on 18 June 2000.

1990 Protocol for the Protection of the Marine Environment Against Pollution from Landbased Sources (Kuwait). In force on 2 January 1993.

1991 Convention on Environmental Impact Assessment in a Transboundary Context (Espoo), 30 II M (1971), 802; B\& B Docs, 31. In force on 27 June 1997.

1991 Protocol on Environmental Protection to the Antarctic Treaty. In force on 14 January 1998.

1991 Protocol to the Antarctic Treaty on Environmental Protection, 30 ILM (1991), 1461; BひB Docs, 468. In force on 14 January 1998.

1992 Declaration of the UN Conference on Environment and Development, UN Doc. A/CONF.151/26/Rev.1, Report of the UNCED, vol. 1

(New York) BळB Docs, 9.

1992 Framework Convention on Climate Change, 31 ILM (1992), 851; B\&B Docs, 252. In force on 21 March 1994. 
1992 Convention on Biological Diversity, 31 ILM (1992) 818; B\&B Docs, 390. In force on 29 December 1993.

1992 Non-Legally Binding Authoritative Statement of Principles for a Global Consensus on the Management, Conservation and Sustainable Development of all Types of Forests, 31 ILM (1992), 881; 3 RECIEL (1992), 830.

1992 Convention on the Transboundary Effects of Industrial Accidents (Espoo), 31 ILM (1992), 1333; B\&B Docs, 50. In force on 19 April 2000.

1992 Convention for the Protection of the Marine Environment of the N.E. Atlantic (Paris), 3 RECIEL (1992), 759; 32 ILM (1993), 1072. In force on 25 March 1998.

1992 Convention on the Protection of the Marine Environment of the Baltic Sea Area (Helsinki). In force on 17 January 2000.

1992 Convention on Civil Liability for Oil Pollution Damage, B\&B Docs, 91. In force on 3 May 1996. Amended by Protocol 2000, in force on 1 November 2003.

1992 Convention on the Establishment of an International Fund for Compensation for Oil Pollution Damage, B\&B Docs, 107. In force on 30 May 1996. Amended by Protocol 2000, in force on 1 November 2003.

1992. Convention on the Protection of the Black Sea Against Pollution (Bucharest), with Protocols on Pollution from Land-based Sources, Combating Pollution in Emergency Situations, and Pollution by Dumping, 32 ILM (1993), 1110. All in force on 15 January 1994.

1993 FAO Agreement to Promote Compliance with Conservation Measures on the High Seas, 33 ILM (1994), 969, B\&B Docs, 645. In force on 24 April 2003.

1994 Protocol for the Protection of the Mediterranean Sea Against Pollution Resulting from Exploration and Exploitation of the Continental Shelf and the Seabed and its Subsoil (Offshore Protocol) (Madrid). Not in force.

1995 UN Agreement Relating to the Conservation and Management of Straddling Fish Stocks and Migratory Fish Stocks, 34 ILM 1542; (1995) 6 RECIEL 841. In force on 11 December 2001.

1995 Convention for the Protection of the Marine Environment and the Coastal Region of the Mediterranean (Barcelona). In force on 9 July 2004. Protocols of 1994, 1995, 1996 and 2002 q.v.

1995 Protocol concerning Specially Protected Areas and Biological Diversity in the Mediterranean (Barcelona); 6 RECIEL 887 (1995). In force on 12 December 1999. 
Protocol for the Prevention and Elimination of Pollution of the Mediterranean Sea by Dumping. Not in force.

1995 FAO International Code of Conduct for Responsible Fisheries.

1995 Declaration on the Protection of the Marine Environment from Landbased Activities (Washington), 6 RECIEL (1995), 883.

1995 Agreement on Conservation of African-Eurasian Migratory Water Birds, 6 RECIEL (1995), 907. In force on 1 November 1999.

1996 Protocol to the London Dumping Convention, 36 IL M (1997), 7. Not in force.

1996 Protocol for the Protection of the Mediterranean Against Pollution from Land-Based Sources and Activities (Syracuse), 7 RECIEL (1996), 678. Not in force.

1997 Protocol to the Framework Convention on Climate Change (Kyoto), 37 ILM (1998), 22. In force on 16 February 2005.

1998 Convention on Access to Information, Public Participation in Decision-making and Access to Justice in Environmental Matters (Arhus). 38 ILM (1999), 517. In force on 30 October 2001.

1998 Convention on the Protection of the Environment through Criminal Law, ETS No. 172; 38 ILM (1999), 259. Not in force.

1998 Protocol on the Control of Marine Transboundary Movements And Disposal of Hazardous Wastes and Other Wastes (under Kuwait Convention of 1978) (Tehran). Not in force.

1999 Protocol on Marine Pollution from Land-based Sources and Activities in the Caribbean Region. Not in force.

2002 Convention for Cooperation in the Protection and Sustainable Development of the Marine and Coastal Environment of the Northeast Pacific (Antigua). Not in force.

2002 Protocol concerning Cooperation in Preventing Pollution from Ships and, in Cases of Emergency, Combating Pollution of the Mediterranean Sea (Prevention and Emergency Protocol) (Valetta). In force on 17 March 2004.

2003 African Convention on the Conservation of Nature and Natural Resources (Maputo). Not in force.

2003 Framework Convention for the Protection of the Marine Environment of the Caspian Sea (Tehran). Not in force. 


\section{GLOSSARY OF TERMS, ACRONYMS AND ABBREVIATIONS}

CMPs

Coast

Coastal area

Coastal zone

Command and control policy

instruments

Conservation

CZMP

Ecosystem
Coastal Management Programs (produced by States and Territories of the United States)

The geographical area of contact between the terrestrial and marine environments, a boundary area of indefinite width, appreciably wider than the shore.

A geographic entity of land and water affected by the biological and physical processes of both the terrestrial and the marine environments, and defined broadly for the purpose of natural resources management. (Coastal area boundaries usually change over time without regard to enabling legislation.)

A geographical entity including both terrestrial and submerged areas of the coast, defined legally or administratively for coastal zone management.

Mechanisms (often laws) for implementing policies that rely on prescribing modes or standards of behaviour and using sanctions to enforce compliance with them.

Includes protection, maintenance, rehabilitation, restoration and enhancement of populations and ecosystems.

Coastal Zone Management Program (United States)

A natural entity (or a system) with distinct structures and relationships that interlink biotic communities (of plants and animals) to each other and link them to their abiotic environment. The study of an ecosystem provides a methodological basis for complex synthesis between organisms and their environment. A complex of ecosystems is constituted by many ecosystems and is characterized by a common origin or common dynamic processes (for example, the complex of the ecosystems of a watershed).

Environmental A sequential set of activities designed to identify and predict the impact impacts of a proposed action on the biogeophysical assessment (EIA) environment and on human health and well being, and to interpret and communicate information about the impacts, 
including mitigation measures that are likely to eliminate risks. In many countries, organizations planning new projects are required by law to conduct EIA.

ICM

Indicators

Integrated coastal area management (ICM)

Land-use planning

Legislation

National legislation

Natural resources
Integrated coastal management

Signals of processes - inputs, outputs, effects, results, outcomes, impacts, etc. - that enable them to be judged or measured. Both qualitative and quantitative indicators are needed for management, policy review, monitoring and evaluation.

A dynamic process by which actions are taken for the use, development and protection of coastal resources and areas to achieve national goals established in cooperation with user groups and regional and local authorities. In this definition, integrated management refers to the management of sectoral components as parts of a functional whole with explicit recognition that it is the users of resources, not the stocks of natural resources, which are the focus of management.

The systematic assessment of land and water potential, alternative patterns of land use and other physical, social and economic conditions, for the purpose of selecting and adopting the land-use options that are most beneficial to land users without degrading the resources of the environment, together with the selection of measures most likely to encourage such land uses (Choudhury and Jansen, 1997).

A written law (act, regulation, decree, ordinance, orders, etc.) passed by a legislative body. Minister or other organ of State to whom or which legislative power has been delegated.

Legislation forming part of municipal or domestic law as distinct from international law. For the purposes of this study, legislation emanating from sub-national authorities such as the governments of federal states constitutes "national" legislation.

Any portion of the natural environment, such as air, water, soil, botanical and zoological resources and minerals. A renewable resource can potentially last indefinitely (provided stocks are not overexploited) without reducing the available supply because it is replaced through natural processes (either because it recycles rapidly, as water does, or because it is alive and can propagate itself or be propagated, as some organisms and ecosystems do). Non-renewable resources (such as coal and oil) 
may eventually be replaced by natural processes, but these processes occur over long periods of geologic time rather than within the time-frame of current generations, and their consumption necessarily involves their depletion.

Objectives The aims of an action, or what is intended to be achieved. Any objective will include explicit statements against which progress can be measured, and will identify which outcomes are truly important and the way that they interrelate; quantified objectives are referred to as targets.

OCRM Office of Ocean and Coastal Resources Management of the Federal Government of the United States (formerly the Office of Coastal Zone Management).

Programme Descriptive notice of series of events, including an indication of the intended proceedings. In these guidelines, the term is used for an undertaking structured around a defined objective, usually consisting of a number of projects.

Stakeholders Individuals and groups of individuals (including government and non-governmental institutions, traditional communities, universities, research institutions, development agencies, banks and donors) with an interest or claim (whether stated or implied) that has the potential of being affected by or affecting a given project and its objectives. Stakeholder groups that have a direct or indirect "stake" can be at the household, community, local, regional, national or international level.

Strategy A coherent statement indicating how resources will be deployed and the approach that will be taken to achieve one or more objectives successfully (often set out in a policy or plan).

US CZMA Coastal Zone Management Act of 1972 (United States). 


\section{TABLE OF CONTENTS}

Foreword iii

Users' Guide vi

Boxes vii

Treaties and Instruments ... viii

Glossary of Terms, Acronyms and Abbreviations ................................................. xiv

Table of Contents .................................................................................................. xvii

\section{PART I - THE CONTEXT FOR NATIONAL ICM LAW} 1

I. THE ROLE AND PURPOSE OF ICM LAW 3

1.1. Governance in Integrated Coastal Management ............................................. 3

1.2. The Role of Law in Integrated Coastal Management .................................. 6

1.3. Meaning and Purpose of ICM Legislation ....................................................... 7

1.4. The Idea of Integrated Coastal Management ................................................. 9

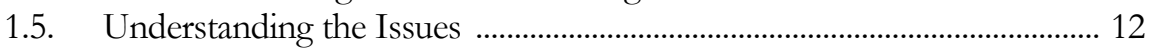

1.5.1. Value of the Coast .............................................................................. 12

1.5.2. Magnitude and Urgency of the Challenge ...................................... 13

1.5.3. Main Pressures on Coastal Environments .................................... 14

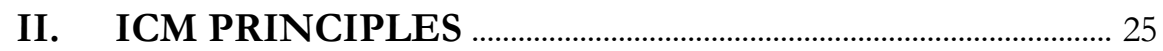

2.1. Nature and Importance of Principles ...................................................... 25

2.2. Management Principles ......................................................................... 27

2.3. Legal Principles .......................................................................................... 32

2.3.1. The Seashore and Sea as Public Property ..................................... 33

2.3.2. Prioritization of Coast-Dependent Development ....................... 35

III. INFLUENCE OF INTERNATIONAL LAW AND POLICY …………………………………………………... 36

3.1. International and Regional Context for National ICM ............................. 36

3.2. Evolution of ICM as a Matter of International Concern ......................... 36

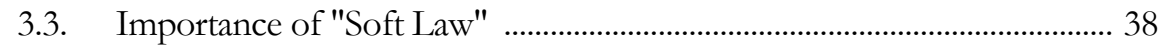

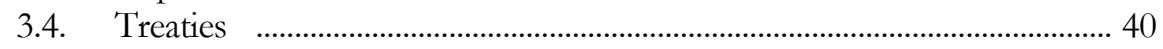

3.4.1. Global Treaties .................................................................................... 40

3.4.2. Regional Treaties ................................................................................... 43

3.4.3. Other Supra-National Instruments ................................................. 46 
3.5. Principles of International Law Relevant

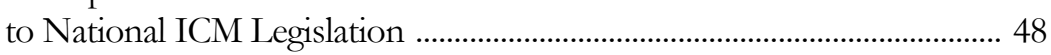

3.5.1. The Importance of International Law Principles ....................... 48

3.5.2. Duty to Prevent, Reduce and Control Environmental Harm

3.5.3. Sustainable Development and Use of Resources ........................ 51

3.5.4. Principle of Preventive Action .................................................... 53

3.5.5. Precautionary Principle ................................................................... 54

3.5.6. Polluter Pays Principle ............................................................... 57

3.5.7. Equitable and Sustainable Use ...................................................... 58

3.5.8. Public Participation ..................................................................... 59

3.5.9. Taking Account of International Law Principles ........................ 60

\section{PART II - DEVELOPING A LEGAL FRAMEWORK}

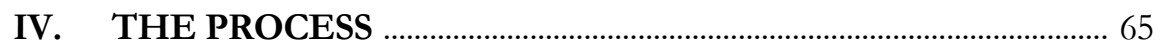

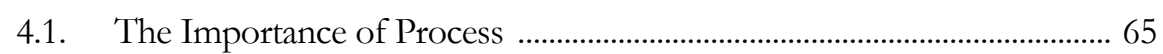

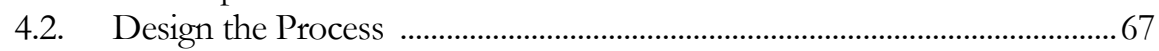

4.3. Define Overall Purpose, Policy Objectives and Legal Objectives .......... 69

4.3.1. Increasing Legal Certainty and the Quality and Transparency of Decision-Making Processes .............................. 70

4.3.2. Reducing the Cost to the State of Implementing and Enforcing Coastal Laws ................................................................... 71

4.3.3. Improving Communication About the Law ................................ 72

4.3.4. Involving Stakeholders .................................................................... 72

4.4. Analyse and Evaluate Existing Governance Framework ........................... 73

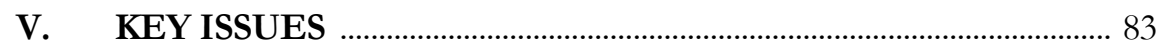

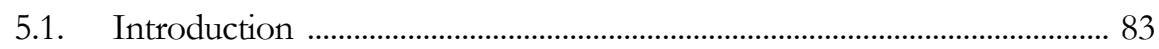

5.2. Defining the Coastal Zone ................................................................................ 83

5.2.1. Substantive Definitions Based on Ecological Features .............. 86

5.2.2. Substantive Definitions Limited by Boundaries .......................... 88

5.2.3. Defining Coastal Property Rights ................................................. 88

5.2.4. Using Multiple Definitions ............................................................. 89

5.3. Demarcating the Coastal Zone ................................................................. 91

5.3.1. Seaward Boundary ......................................................................... 91

5.3.2. Landward Boundary ...................................................................... 93 
5.4. Rights to Own and Use Coastal Areas ......................................................... 96

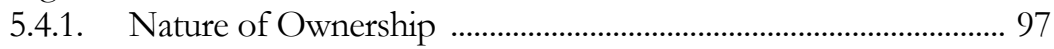

5.4.2. Ownership in Coastal Areas ............................................................ 98

5.4.3. Use rights in Coastal Areas ........................................................... 99

5.4.4. Customary Law Regimes ............................................................... 99

5.4.5. Changing Rights to Use and Manage Coastal Resources ........ 101

5.5. Conflict Reduction and Resolution ........................................................... 104

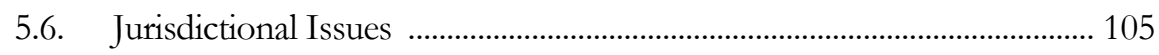

PART III - LEGAL APPROACHES AND TECHNIQUES ......... 65

VI. APPROACHES TO ICM LEGISLATION IN

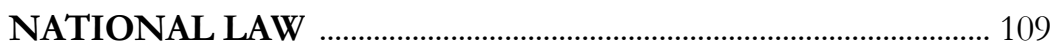

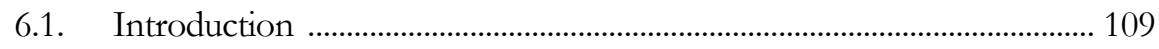

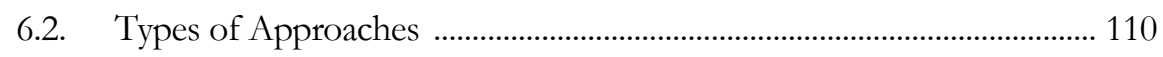

6.3. National Integrated Coastal Management Approach .............................. 111

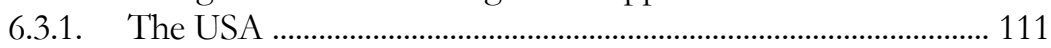

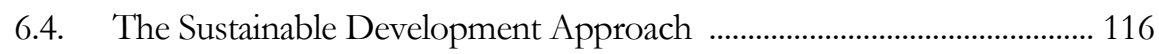

6.4.1. New Zealand ....................................................................................... 116

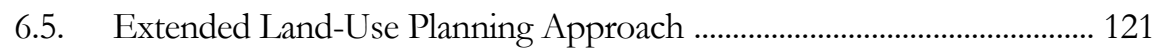

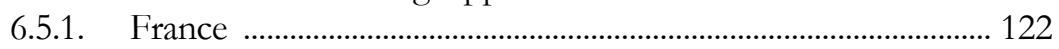

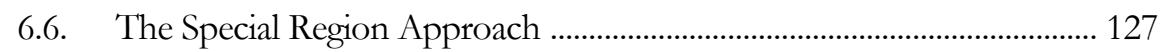

6.6.1. Regional Harbour Plans ................................................................. 128

6.6.2. The Languedoc-Roussillon Region in France ............................. 129

6.6.3. Protection of Wetlands and Other Critical Habitats ................. 132

\section{TECHNIQUES FOR ADDRESSING KEY}

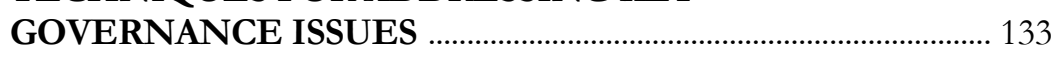

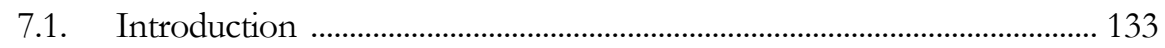

7.2. Identifying and Using Appropriate Legal Techniques ............................ 134

7.3. Formulating Integrated Coastal Policies ..................................................... 135

7.3.1. The Importance of Integrated CMPs ............................................ 135

7.3.2. Issues to be Considered ................................................................... 136

7.3.3. Promoting an Integrated, Non-Sectoral Approach to Policy Formulation .......................................................................... 136

7.3.4. Establishing a Duty to Formulate and Review CMPs .............. 138

7.3.5. Achieving Mutually Consistent CMPs ......................................... 139

7.3.6. Nature of Coastal Management Programmes ............................ 141 
7.4. Public Participation and the Devolution of Power ................................. 145

7.4.1. Achieving Effective Public Participation .................................... 145

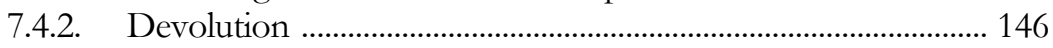

7.5. Information Management .......................................................................... 151

7.5.1. Why Information Management is Important ............................ 151

7.5.2. Impacts on Legislation …………………………........................ 152

7.5.3. Impacts on Compliance ………………………………………... 153

7.5.4. Refining Coastal Governance Systems ....................................... 153

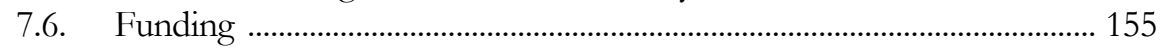

VIII. TECHNIQUES FOR PRESERVING THE INTEGRITY AND PUBLIC CHARACTER OF THE COAST ……………………..... 158

8.1. Introduction ...................................................................................... 158

8.2. Strengthening the Legal Status of the Coast as a Public Commons ..... 160

8.3. Extending the Coast ................................................................................. 162

8.4. Custodianship of the Coast .......................................................................... 164

8.5. Creating a Duty of Care in Relation to the Coast ...................................... 166

8.6. Equitable Access to Coastal Opportunities and Benefits ......................... 167

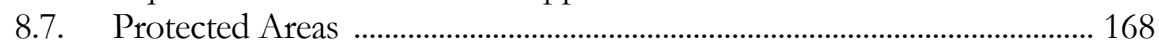

8.8. Maintaining Environmental Quality ............................................................ 169

8.9. Preserving the Natural Character of the Coast .......................................... 170

\section{TECHNIQUES FOR GUIDING} INFRA-STRUCTURAL DEVELOPMENT ......................... 172

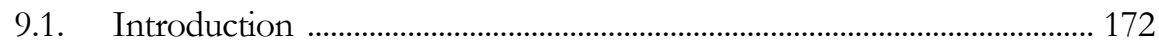

9.2. Planning Instruments ............................................................................ 173

9.2.1. Changing the Legal Status of Land Adjacent to the

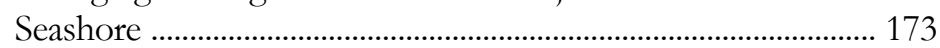

9.2.2. Coastal Set-Back Lines and Exclusion Zones ........................... 176

9.2.3. Multiple Special-Purpose Zones ................................................. 182

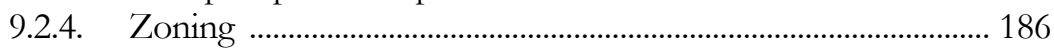

9.2.5. Demarcating Zones ....................................................................... 190

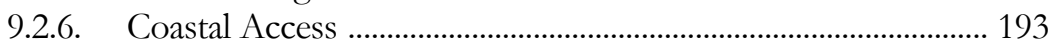

9.3. Development Control ................................................................................. 193

9.3.1. Discretionary Administrative Controls on Development ...... 194

9.4. Environmental Assessment Procedures .................................................. 196

9.4.1. EIAs of Proposed Projects ...................................................... 198

9.4.2. New Challenges for Coastal EIA Systems .................................. 202 
9.4.3. Environmental Auditing of Existing

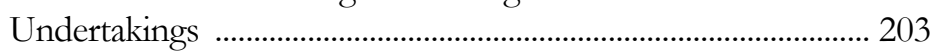

9.4.4. Strategic Environmental Assessment ........................................ 204

\section{TECHNIQUES FOR PROMOTING THE SUSTAINABLE} USE OF COASTAL RESOURCES ................................................... 205

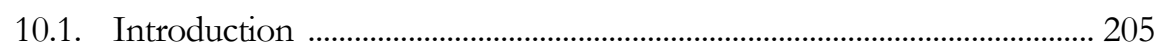

10.2. Planning Instruments for Coastal Resource Management ...................... 207

10.3. Authorization Systems .............................................................................. 208

10.3.1. The Rationale for Authorization Systems ................................ 208

10.3.2. Integrated Authorization Systems ............................................... 209

10.4. Economic Instruments for Sustainable Use ............................................ 212

XI. ENSURING COMPLIANCE _.......................................................... 214

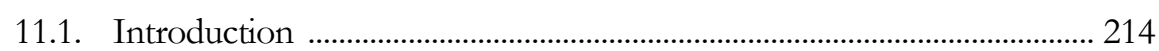

11.2. Factors Affecting Compliance ................................................................ 214

11.3. How to Increase Compliance ................................................................... 217

11.3.1. Changing Perceptions of the Law ............................................... 217

11.3.2. Increasing Legal Risk .................................................................... 217

11.3.3. Reducing Disincentives to Compliance ....................................... 220

XII. INSTITUTIONAL ASPECTS …………………………………….... 221

12.1. The Interdependence of Laws and Institutions ........................................ 221

12.2. Moving Towards More Integrated Institutional Arrangements ............ 222

12.2.1. Creating New Agencies ................................................................. 223

12.2.2. Designating Lead Agencies .......................................................... 223

12.2.3. Advisory Councils Without Executive Powers (Victoria, Australia and Thailand) ................................................................... 224

12.3. Formulating the ICM Programme ................................................................ 225

12.4. Legislative (Rule-Making) Functions ………………………………….. 229

12.5. Executive Functions ………………………………………………………..... 230

PART IV - GLOBAL DEVELOPMENT OF ICM LAW ......... 233

XIII. CURRENT AND FUTURE TRENDS IN ICM LAW .............. 235

13.1. The Future of ICM Law .......................................................................... 235

13.1.1. Continuing Deterioration of Coastal Environments ................. 235

13.1.2. Emergence of New Challenges .................................................... 235

13.1.3. International Endorsement of the ICM Approach ..................... 236 


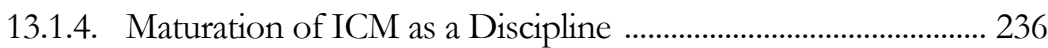

13.1.5. Endorsement of ICM at the Regional Level ............................. 236

13.1.6. Information Technology and the Availability of Information

13.1.7. Maturation of International Law Concerning the Environment

13.1.8. Establishment and Strengthening of National Environmental Laws

13.2. International Trends

13.2.1. Influence of International Instruments ..................................... 238

13.2.2. Overriding Importance of Maintaining Ecological Integrity

13.2.3. Integration with Oceans Management ......................................... 239

13.2.4. Influence of ICM on Environmental Law ................................. 240

13.3. Overview and Conclusions ................................................................ 240

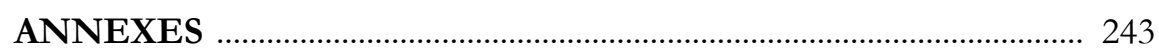

ANNEX 1 - THE ECOSYSTEM APPROACH ........................................ 245

ANNEX 2 - SELECTED NON-BINDING

INTERNATIONAL ENDORSEMENTS FOR THE

NATIONAL ADOPTION OF ICM

ANNEX 3 - THE PROCESS OF DEVELOPING A CONSENSUS BASED COASTAL MANAGEMENT 
PART I

THE CONTEXT FOR NATIONAL ICM LAW 


\section{ROLE AND PURPOSE OF ICM LAW}

\subsection{Governance in Integrated Coastal Management}

Integrated coastal management (ICM) is an approach to managing a defined coastal area that understands the coast as a complex and dynamic system that encompasses many interactions between people and ecosystems, and must be managed as an integrated whole. It is an ongoing process of formulating, implementing and refining a comprehensive and holistic vision of how humans should interact in an ecologically sustainable manner with the coastal environment. (The nature of ICM is discussed more fully in section 1.4. below).

The governments of most countries have tended to categorize human activities into sectors (e.g. agriculture, mining and tourism) and then establish different government agencies to manage each sector. This sectoral approach means that activities within the coastal area that relate to different sectors are regulated separately. This approach does not recognize that coastal areas have any distinctive characteristics that necessitate different management approaches. For example, sectoral approaches usually regulate each type of activity (e.g. the construction of roads) in the same way regardless of whether or not it takes place near the coast. In the past few decades it has become abundantly clear that sectoral management approaches have failed to prevent the rapid deterioration of coastal environments.

ICM has been developed partly in response to this failure. The fundamental conceptual shift involved in moving to integrated coastal management is the recognition that the reason why the sectoral approach to managing human activities in the coastal zone was that it does not take into account the fact that the coast is an integrated system with distinctive characteristics.

The term "coastal management" suggests that ICM is concerned with managing the coastal environment itself, and indeed this is how many coastal managers understand it. Although many of the activities included in an ICM programme (such as the setting of water quality objectives) may appear to be

"The need for a cross sectoral, holistic approach to managing marine and coastal environments, and their watersheds, is now widely recognised and has been formalised as the discipline of integrated coastal management (ICM)." (UNEP 2002, p. 186)

concerned with managing the coast itself, in fact they are responses to unwanted human-induced change to the coastal environment. In other cases, 
the perception that the humans should strive to dominate or "tame" natural coastal forces has resulted in coastal management focussing on activities such as constructing sea walls, groynes and other infrastructure, often referred to collectively as "sea defences". Many of these management interventions have failed, and from an ICM perspective would be regarded as inappropriate because they are based on the false perception that humans are not part of coastal systems and must oppose, rather than work with, natural coastal processes.

ICM is therefore better conceived of as the process of managing human activities within a defined area centred on the seashore, particularly those that have a significant impact on the environment. This means that governing human behaviour (i.e. governance) is at the heart of ICM. Law is one of the principal tools of societal governance, and consequently law is of central importance to any sustained ICM initiative.

Many of the earlier ICM initiatives did not fully appreciate the importance of law to the ICM process. This was probably due at least partially to the fact that initiatives were often driven primarily by natural scientists who understood the focus of ICM to be the scientific management of coastal ecosystems rather than managing their human users. In some cases, these initiatives produced sophisticated coastal management programmes and plans, but implementation proved difficult because inadequate attention had been given to existing legal frameworks. For example, it may be extremely difficult to implement an integrated plan if the powers and jurisdictions of public bodies prevent cross-sectoral decision-making or if the freedom of coastal land owners to develop their land is not restricted by law.

Coastal management programmes must therefore both be tailored to take account of the realities of existing legal and institutional frameworks, and, where appropriate, include strategies for changing the laws to remove obstacles and to create a legal framework which facilitates integrated coastal management. Fortunately it is now widely accepted that it is important to undertake a detailed analysis of existing legal and institutional frameworks at an early stage in the development of an ICM programme. As discussed in section 1.2 below, it is also important, when analysing legal and institutional frameworks relevant to ICM and when designing new legal frameworks to promote ICM, that consideration is given to the different roles which law can play. 


\section{Box 1 \\ SOME DEFINITIONS OF INTEGRATED COASTAL MANAGEMENT}

"A dynamic process by which actions are taken for the use, development and protection of coastal resources and areas to achieve national goals established in cooperation with user groups and regional and local authorities, In this definition, integrated management refers to the management of sectoral components as parts of a functional whole with the explicit recognition that it is the users of resources, not the stocks of natural resources that are the focus of management. ...". (FAO Guidelines)

"A dynamic process in which a co-ordinated strategy is developed and implemented for the allocation of environmental, socio-cultural and institutional resources to achieve the conservation and sustainable multiple use of the coastal zone". (Campnet 1991)

"A planning and coordinating process which deals with development management and coastal resources and which is focussed on the land/water interface". (Clark 1992)

"ICZM is a governmental process and consists of the legal and institutional framework necessary to ensure that development and management plans for coastal zones are integrated with environmental (including social) goals and are made with the participation of those affected. The purpose of ICZM is to maximize the benefits provided by the coastal zone and to minimize the conflicts and harmful effects of activities upon each other ...". (Draft Guidelines for Integrated Coastal Zone Management, World Bank)

"A dynamic process by which decisions are taken for the use, development and protection of coastal areas and resources to achieve goals established in cooperation with user groups and national, regional and local authorities. Integrated coastal management recognizes the distinctive character of the coastal zone - itself a valuable resource - for current and future generations. Integrated coastal management is multiple purpose oriented, it analyses implications of development, conflicting uses, and interrelationships between physical processes and human activities, and it promotes linkages and harmonisation between sectoral coastal and ocean activities". (Knecht 1979, p. 186.)

"At minimum, any definition should include the integration of programs and plans for economic development and environmental quality management, and more specifically the integration of cross-sectoral plans for fisheries, energy, transportation, waste disposal, tourism, etc. ICM should also include the vertical integration of responsibilities for management actions among various levels of government - international, national, state, and local - or between the public and private sectors. It should include all the components of management - from the planning tasks of analysis and design, to the implementation tasks of installation operation and maintenance, monitoring and evaluation of strategies over time. 
ICM should be cross disciplinary among the sciences, engineering (technology) economics, political science (institutions), and law. In practice, it is all of the above." (Bower et al. 1992.)

"The primary aim of coastal zone management is to provide guidelines for decision makers on the way in which demands for numerous activities can be met without unreasonably disturbing either the balance of the natural systems of the right of all members of the community to use and enjoy the coast". (Report of the Australian House of Representatives Standing Committee on the Management of the Coastal Zone).

\subsection{Role of Law in Integrated Coastal Management}

Law is one of the primary mechanisms used by government to ensure that their policies and programmes are implemented. It is important to appreciate at the outset that laws can play many different functions, some of which are discussed below.

\section{Command and control}

The most familiar role played by law is when a legislative authority (e.g. parliament, municipal council, a Minister to whom rule-making powers have been delegated) passes a law (e.g. an act or regulation) which prescribes certain standards of behaviour and imposes penalties for failure to comply. This type of governance is sometimes called "command and control" because it commands people to do, or refrain from doing, something and then puts in place control measures to ensure that they comply.

\section{Constituting and structuring societies and institutions}

Laws are also used to define political entities, such as states, to constitute entities within them, such as companies or public institutions; and to define the relationships among them. For example, in most countries the constitution defines the way in which power is exercised within that society, and the fundamental nature of the relationships between people and entities within that society and between them and aspects of their environment. This is often achieved by allocating rights and obligations among different groups in society. The rights and obligations (or lack of them) of the members of the public which the law recognizes can also be an important factor in determining how effectively a coastal management programme, policy or plan (CMP) can be implemented and enforced. 
Property laws, in particular, play a major role in defining the relationship between human beings and their environment. This is particularly clear in relation to the management of coastal areas where the management measures that can be taken are typically heavily influenced by whether the area in question is public or private property or some sub-category thereof. (Coastal areas almost always include a combination of several different property regimes.)

States usually use law to establish public institutions and to determine who must make particular decisions and how they must be made. The success or otherwise of coastal management programmes depends heavily on factors such as: the nature of the institutions given responsibility for coastal management, the extent of their jurisdiction (i.e. both the area in which they may exercise their powers and the matters which they are entitled to regulate), and the extent of their powers. This means that it is important to ensure that the legislation that is used to establish bodies with management responsibilities in coastal areas is appropriate and reflects an understanding of coastal management concerns.

\section{Educational}

Another potential function of law that is often overlooked is its educative function. Since law prescribes what conduct a particular society regards as socially acceptable or desirable, laws can play a very important role in changing the attitudes and conduct of members of society. This is particularly true where the legislation is developed in a highly participatory manner that provides an opportunity for stakeholders to discuss the key issues so that they accept and support the rationale behind the new draft legislation before it becomes law. For example, in many countries it is accepted that laws outlawing discrimination on the basis of race or gender have played an important role in changing societal attitudes on these issues over time. The rapid deterioration of the global environment, and in particular of coastal areas, suggests that it will be extremely important to use law as one of the means of changing the way in which people perceive their relationship with the coastal environment, and consequently how they interact with it.

\subsection{Meaning and Purpose of ICM Legislation}

In order to implement an ICM programme, it is almost invariably necessary to repeal or amend existing legislation and, frequently, to enact entirely new 
legislation. These legislative changes may be intended to achieve a wide variety of objectives, including: changing how existing institutions operate to enable and facilitate integrated management, creating new institutions, changing the rights of different parties to use the coastal environment, introducing new mechanisms to regulate human activities that may have a negative impact on coastal areas (e.g. permit systems or requirements to undertake environmental assessments of proposed activities or plans), or creating more effective dispute resolution procedures. Before embarking on what may be an extensive process of legislative reform, it is important to be clear, firstly, on what is meant by integrated coastal management law, and secondly, exactly what the overall purpose and specific objectives of the reform agenda are.

\section{What is meant by "ICM law"?}

The focus of this book is on national law (i.e. the "domestic" laws that apply within a country, whether at a national, provincial/state, or local level) as opposed to the international law, which regulates the relationship between countries, although the two are obviously closely interrelated. However, in any jurisdiction, a wide variety of laws with diverse purposes influence how human activities within coastal areas are regulated. Typically, these will include legislation related to: mining, fishing, aquaculture, land-use planning and development, shipping, and the environment. Although such laws may affect coastal management, they may not contribute to integrated coastal management and in fact may often hinder it by entrenching sectoral divisions and failing to take account of the integrated and distinctive nature of coastal areas. Therefore the term "ICM law" must be confined to a smaller subset of laws that in some way gives effect to the fundamentals of the ICM approach.

The term "ICM law" is used in this publication to refer to laws (primarily national legislation) that:

1. expressly or implicitly acknowledge the need for special coast-specific rules, principles or other legal mechanisms;

2. are fundamentally concerned with the use and protection of the environment within coastal areas, which are defined to include both sea and land; and 
3. expressly or implicitly aim to achieve an approach to managing human interactions with the coastal environment in a manner that is based on an appreciation that the coast is an integrated ecological whole, and that coastal management must take into account the implications of any action or proposed action for the coastal system as a whole rather than merely for any particular sector.

Some of the laws considered here do not themselves meet all of these criteria, but have been included because they form part of a legislative framework, which taken as a whole, meets these criteria.

\section{The purpose of ICM law}

The primary purpose of ICM law is to establish a governance system that enables, facilitates and supports an integrated approach to managing human uses of coastal areas. This will also usually be the, or one of the, overarching goals of any ICM legislative and institutional reform programme ${ }^{5}$. As discussed in Part III, there are many ways of giving effect to this purpose. Indeed it is appropriate and desirable to use a range of different mechanisms to achieve ICM policies. Furthermore, the diversity of coastal environments, socio-economic factors, political and legal structures both between and within countries throughout the world, mean that it is important that legislation for ICM show a similar degree of diversity in order that it may be appropriate to local conditions.

However, if the primary purpose of ICM legislation is to promote ICM, this begs the question: "What is meant by integrated coastal management?"

\subsection{The Idea of Integrated Coastal Management}

There is no generally accepted definition of integrated coastal management (see Box 1 for examples of definitions of ICM), but there is a widespread international consensus as to its main features (see Box 2). The main feature that distinguishes ICM from other approaches to coastal management is that it is based on the understanding that any human use of the coast affects both other users and the coastal ecosystem as a whole.

5 See section 4.3 for a discussion of the goals and objectives of legislative reform processes. 
From a legal and institutional perspective it is particularly important to note that:

- ICM is based on the management of a defined area or zone rather than of a particular sector or use;

- ICM is concerned with the organization and co-ordination of institutional and other human resources for the purpose of attaining long-term strategic objectives that relate both to the protection of coastal environments and the use of coastal environments by humans;

- the coast is seen as a dynamic system composed of many subsystems (e.g. ecosystems) and that in order to effectively regulate a part of a system, it is necessary to understand and respect its role and function within the whole;

- coastal areas require an integrated and holistic management approach instead of a sectoral approach that manages human activities that fall within different sectors (e.g. agriculture, mining or tourism) separately;

- planning and decision-making in relation to the coast must take account of the actual or potential impacts of any human activity on the coastal system as a whole;

- management goals and objectives for the coast must be mutually compatible, and be capable of being unified into a comprehensive whole (i.e. truly integrated) and it is insufficient merely to co-ordinate separately devised sectoral programmes;

- coastal management objectives can best be achieved by building cooperative and co-ordinated approaches to implementation; and

- ICM requires balancing competing human demands for the use of the coast and resolving conflicts among coastal users, among coastal management institutions and between them and coastal users. 


\section{Box 2}

\section{A CONSENSUS SET OF INTEGRATED COASTAL MANAGEMENT GUIDELINES}

\begin{tabular}{|ll|}
\hline Purpose of ICM & The aim of ICM is to guide coastal area development in an \\
ecologically sustainable fashion. & \\
& ICM is guided by the Rio Principles with special emphasis \\
& on the principle of intergenerational equity, the \\
& precautionary principle and the polluter pays principle. \\
& ICM is holistic and interdisciplinary in nature, especially \\
& with regard to science and policy. \\
Functions & ICM strengthens and harmonizes sectoral management in the \\
& coastal zone. It preserves and protects the productivity and \\
biological diversity of coastal ecosystems and maintains amenity \\
values. ICM promotes the rational economic development and \\
sustainable utilization of coastal and ocean resources and \\
facilitates conflict resolution in the coastal zone. \\
An ICM programme embraces all of the coastal and upland \\
areas, the uses of which can affect coastal waters and the \\
resources therein, and extends seaward to include that part of \\
the coastal ocean that can affect the land of the coastal zone. \\
The ICM programme may also include the entire ocean area \\
under national jurisdiction (Exclusive Economic Zone), over \\
which national governments have stewardship responsibilities \\
under both the Law and the Sea Convention and UNCED. \\
Overcoming the sectoral and intergovernmental fragmentation \\
that exists in today's coastal management efforts is a prime goal \\
of ICM. Institutional mechanisms for effective coordination \\
among various sectors active in the coastal zone and between \\
the various levels of government operating in the coastal zone \\
are fundamental to the strengthening and rationalization of the \\
coastal management process. From the variety of available \\
options, the coordination and harmonization mechanism must \\
be tailored to fit the unique aspects of each particular national \\
government setting. \\
Given the complexities and uncertainties that exist in the coastal \\
zone, ICM must be built upon the best science (natural and \\
social) available. Techniques such as risk assessment, economic \\
valuation, vulnerability assessments, resource accounting, benefit- \\
cost analysis and outcome-based monitoring should all be built \\
into the ICM process, as appropriate.
\end{tabular}

Source: Cicin-Sain, Knecht and Fisk, 1995. 


\subsection{Understanding the Issues}

A full exploration of the many important matters that must be considered in implementing ICM is beyond the scope of this publication, and is well canvassed in many of the excellent publications on the subject that are available today. Nevertheless, it is essential for anyone involved in designing or strengthening legislative frameworks for ICM to have a good appreciation of:

- the value and importance of the coast, not only in terms of its contribution to GDP, but also its ecological, social and spiritual values;

- the urgency of taking effective action to prevent the rapid degradation of coastal areas world-wide; and

- the underlying causes of coastal degradation, the international and regional legal and policy responses to these pressures, and the legislative and other legal measures that may be taken at a national or sub-national level in order to address these issues. (A brief overview of these factors is given in Box 3.)

\subsubsection{Value of the Coast}

In the recent past, most countries failed to recognize the full value of the coast to society. One of the reasons for this is that information about goods and services was collected on a sectoral basis and was not aggregated according to whether or not they were derived from coastal ecosystems. In other words, the Gross Domestic Product of a country would be analyzed to reveal the contributions made by different sectors such as tourism, agriculture and forestry, but not to determine the contribution made by coastal as opposed to inland areas. In 2000 when South Africa aggregated the benefits derived from coastal ecosystems in the course of developing a national coastal policy and programme, it was discovered that the value of direct benefits obtained from all coastal goods and services was about 168 billion Rand annually. Indirect benefits from coastal ecosystems such as erosion control and waste treatment were estimated to contribute a further 134 billion Rand annually. ${ }^{6}$ Furthermore, as the White Paper points out, the coast also has

6 White Paper for Sustainable Coastal Development in South Africa, April 2000, p. 5. 
significant aesthetic, cultural, educational, scientific and spiritual values which are not capable of being meaningfully measured in financial terms.

In the European Union, studies have indicated that the Union's most valuable habitats are to be found in coastal areas, and that the total ecosystem benefits generated by EU coastal zones are worth more in economic terms than the national GDP of many of the smaller EU countries. About half the population of these Member States with coastline, live within 50 kilometres of the sea. According to studies commissioned by the European Union, the estimated gross annual socioeconomic benefits of introducing an integrated approach to coastal management could be worth up to $€ 4.2$ billion. This figure includes the estimated value of habitat protection, and of economic benefits to local businesses and tourism, but excludes the many qualitative benefits anticipated, including more cohesive coastal communities ${ }^{7}$.

\subsubsection{Magnitude and Urgency of the Challenge}

The Third Global Environment Outlook (GEO 3), published by UNEP immediately prior to the World Summit on Sustainable Development in South Africa in August 2000, contains a sobering assessment of the ongoing degradation of coastal and marine areas. As the report points out, coastal and marine environmental degradation has not only continued but has intensified despite national and international actions to address marine pollution, the over exploitation of living marine resources and the loss of coastal habitats ${ }^{8}$. The degradation is being caused by increased pressure on both the terrestrial and marine aspects of coastal ecosystems and by the use of oceans to deposit waste. This in turn is being driven by increased population growth, the effect of which is exacerbated in coastal areas by an intensification of urbanization, industrialization and tourism along the world's coasts. Furthermore, as GEO 3 points out, the impact of population increases is increased by both poverty and excessive human consumption patterns.

7 European Commission 2001, Turning the Tide for Europe's Coastal Zones, p. 6. See also Firn Crichton Roberts, 2000.

8 UNEP 2002, p. 180. 


\subsubsection{Main Pressures on Coastal Environments}

The main direct pressures on coastal ecosystems are:

- pollution (from a variety of sources including marine pollution from ships and land based sources, and atmospheric emissions affecting both marine and terrestrial areas);

- physical alteration of coastal areas (due to, e.g. urbanization, industrialization, tourism, agriculture) and of inland areas which impact on the coastal environment (e.g. the damming of rivers or the deforestation of catchment areas);

- over-exploitation of living resources, primarily fish stocks;

- inappropriate and excessive exploitation of non-living resources, including mining, excessive water consumption and watershed erosion;

- global climate change, which is producing a variety of impacts including melting of the polar ice packs, sea level rise, coral bleaching and increased natural hazards due to climatic disturbances; and

- introduction of exotic species, for example, via ships' ballast water.

\section{Marine pollution}

Globally, sewage is the largest (by volume) source of contamination of the marine and coastal environment and coastal sewage discharges have increased dramatically in the past three decades'. The contamination of coastal waters with sewage-borne pathogens is a health problem of global proportions. It is estimated to cause annual global losses in excess of 3.2 million years of lost productive life through death or disability, and to have an annual economic impact in excess of US\$12.8 billion ${ }^{10}$.

Another worrying trend is marine and coastal eutrophication from increased nitrogen levels. The supply of fixed nitrogen to the oceans as a result of human activities has increased greatly and nitrogen levels are being exacerbated by widespread loss of coastal wetlands, coral reefs and mangrove forests. This arises from a variety of causes including the runoff

9 GESAMP 2001a.

10 GESAMP 2001a, WHO 2003. 
from farms using fertilizers and manure, evaporation from animal manure and fertiliser, and vehicle and industrial emissions. Severe eutrophication has occurred in several enclosed or semi-enclosed seas, while in other areas the increased growth and subsequent decay of phytoplankton has caused widespread areas of seasonally oxygen depleted water. There is increasing evidence that blooms of toxic or otherwise undesirable phytoplankton are increasing in frequency, intensity and geographical distribution ${ }^{11}$. These phytoplankton blooms can have a major economic impact on fisheries, aquaculture and tourism.

Since the 1972 UN Conference on the Human Environment held in Stockholm, human-induced changes in the natural flow of sediments have emerged as a major threat to coastal habitats ${ }^{12}$. Increased sedimentation arising from diverse causes (including the construction of residential and industrial infrastructure, agriculture, and deforestation) is one of the major global threats to reefs and sea-grass beds. In other areas, decreases in sediment loads caused for example by dam building, or changes in sediment flows caused by coastal constructions, can have an adverse impact on beaches, deltas and mangrove forests, and result in severe coastal erosion.

\section{Fisheries}

At the time of the Stockholm Conference it was anticipated that marine capture fisheries harvests would give rise to and be sustained at levels in excess of 100 million tonnes per annum. Contrary to expectation, the total appears to have peaked during the 1980s at less than 90 million tonnes and recent studies suggest that catches have been declining for more than a decade ${ }^{13}$. There has been a global trend towards increasingly intense exploitation and depletion of fisheries stocks and three quarters of the world's fisheries are either fully exploited, over-exploited or have collapsed ${ }^{14}$. The full impact of fisheries on marine ecosystems is only now beginning to be appreciated and in many cases the effects are either unknown or alarming. This is particularly because the increase in fisheries yields has been delivered by fishing on progressively smaller species at lower levels in the marine food web as

11 Richardson, 1997.

12 UNEP 2002, p. 315.

13 Watson and Pauly, 2001.

14 FAO, 2004. 
the top predators have been depleted. The negative impacts of fishing have also resulted from the use of inappropriate fishing gear, destructive practices like blast fishing and global by-catch levels of many millions of tonnes.

\section{Pbysical alteration}

The physical alteration of coastal inland areas and the destruction of habitats is now probably the most significant single threat to the coastal environment ${ }^{15}$. Increased population, urbanization, industrialization, marine transport and tourism have increased pressures on coastal environments and in many cases this has been exacerbated by no, or inadequate, planning.

\section{Global climate and atmospheric change}

The potential impacts of the rapid global warming being caused by humaninduced changes in the atmosphere are complex and poorly understood. Polar warming and melting of the ice caps could potentially alter the flow of major ocean currents while warming of the surface of the oceans and increased fresh water could induce the upwelling of nutrients. Most significantly from an ICM perspective, storms, floods and other extreme weather events are increasing in frequency and intensity and are likely to continue to do so, resulting in increased disturbances to coastal ecosystems and potentially reducing their ability to recover ${ }^{16}$.

\section{The introduction of exotic species}

The introduction of exotic aquatic species and pathogens to aquatic environments, in which they do not naturally occur, has sometimes caused devastating damage to marine biodiversity, and local economies. This appears to be occurring with increasing frequency, particularly via ships' ballast water.

15 GESAMP, 2001a.

16 IPCC, 2001. 
Box 3

OVERVIEW OF COASTAL PRESSURES AND IMPACTS AND EXAMPLES OF GLOBAL, REGIONAL AND NATIONAL LEGAL RESPONSES

\begin{tabular}{|c|c|c|c|}
\hline PRESSURE & $\begin{array}{l}\text { IMPACTS (SOCIAL/ } \\
\text { ENVIRONMENTAL) }\end{array}$ & $\begin{array}{c}\text { GLOBAL AND REGIONAL } \\
\text { RESPONSES }\end{array}$ & $\begin{array}{l}\text { NATIONAL LEGISLATIVE } \\
\text { RESPONSES }\end{array}$ \\
\hline \multicolumn{4}{|l|}{ 1. Pollution } \\
\hline $\begin{array}{l}\text { Marine pollution from } \\
\text { ships } \\
\text { Increased trade and marine } \\
\text { transport (particularly the } \\
\text { transportation of oil and } \\
\text { hazardous substances) together } \\
\text { with increased offshore oil and } \\
\text { gas activities has increased the } \\
\text { potential risk from the source. }\end{array}$ & $\begin{array}{l}\text { Oil spills often have } \\
\text { chronic impacts on } \\
\text { wildlife and their } \\
\text { habitats, particularly sea } \\
\text { birds, and may have } \\
\text { more subtle long-term } \\
\text { effects. }\end{array}$ & $\begin{array}{l}\text { Global } \\
\text { Marpol 73/78, } 1972 \\
\text { London Dumping } \\
\text { Convention and } 1996 \\
\text { Protocol. } \\
\text { Regional } \\
\text { UNEP Regional Seas } \\
\text { Conventions, e.g. Protocol to } \\
\text { Barcelona Convention } \\
\text { (Mediterranean) and Protocol } \\
\text { to Cartagena Convention } \\
\text { (Caribbean). }\end{array}$ & $\begin{array}{l}\text { Widespread use of domestic } \\
\text { legislation to implement } \\
\text { international conventions including } \\
\text { legislation: } \\
\text { - establishing liability for oil spill } \\
\text { cleanups and costs; and } \\
\text { - requiring development of } \\
\text { emergency response plans. }\end{array}$ \\
\hline $\begin{array}{l}\text { Marine pollution from } \\
\text { land based sources } \\
\text { These may arise from a } \\
\text { variety of point sources } \\
\text { (e.g. factories) and diffuse }\end{array}$ & $\begin{array}{l}\text { Human health: e.g. from } \\
\text { eating contaminated } \\
\text { seafoods or bathing in } \\
\text { polluted waters. } \\
\text { Nutrient loading and }\end{array}$ & $\begin{array}{l}\text { Global } \\
1972 \text { London Dumping } \\
\text { Convention and } \\
1996 \text { Protocol. } \\
1989 \text { Basel Convention on }\end{array}$ & $\begin{array}{l}\text { - Permit systems for discharges to } \\
\text { land, air and water; } \\
\text { - Environmental impact } \\
\text { assessments; } \\
\text { - Effluent standards; }\end{array}$ \\
\hline
\end{tabular}




\begin{tabular}{|c|c|c|c|}
\hline PRESSURE & $\begin{array}{l}\text { IMPACTS (SOCIAL/ } \\
\text { ENVIRONMENTAL) }\end{array}$ & $\begin{array}{l}\text { GLOBAL AND REGIONAL } \\
\text { RESPONSES }\end{array}$ & $\begin{array}{c}\text { NATIONAL LEGISLATIVE } \\
\text { RESPONSES }\end{array}$ \\
\hline $\begin{array}{l}\text { sources (e.g. run-off from } \\
\text { fields). Sources include } \\
\text { hazardous substances from } \\
\text { industry, pesticides, and } \\
\text { nitrogen from the agricultural } \\
\text { sector, effluent from fish } \\
\text { processing, radio-active } \\
\text { pollution and heat from } \\
\text { nuclear power stations, etc. }\end{array}$ & $\begin{array}{l}\text { eutrophication of coastal } \\
\text { waters, particularly from } \\
\text { elevated levels of } \\
\text { nitrogen and phosphates. } \\
\text { Socio-economic impacts } \\
\text { on fisheries, aquaculture } \\
\text { and tourism industries. } \\
\text { Ecosystem impacts, } \\
\text { e.g. mortalities from } \\
\text { oxygen depletion, } \\
\text { mortalities caused by } \\
\text { litter and bio- } \\
\text { accumulation of } \\
\text { hazardous substances. }\end{array}$ & $\begin{array}{l}\text { the Control of } \\
\text { Transboundary Movement } \\
\text { of Hazardous Wastes and } \\
\text { their Disposal. } \\
1995 \text { Global Programme of } \\
\text { Action for the Protection of } \\
\text { the Marine Environment } \\
\text { from Land-Based Activities. } \\
\text { Regional } \\
\text { UNEP Regional Seas } \\
\text { Programme (initiated } \\
\text { 1974). } \\
\text { Africa } \\
\text { Abidjan Convention, } \\
\text { Nairobi Convention } \\
\text { Europe } \\
\text { OSPAR, Helcom, } \\
\text { Mediterranean Action Plan, } \\
\text { Convention for the } \\
\text { protection of the North East } \\
\text { Atlantic and Co-operation } \\
\text { agreement re the North East }\end{array}$ & $\begin{array}{l}\text { - Objectives for coastal and fresh } \\
\text { water quality and coastal } \\
\text { management; } \\
\text { - Control of products containing } \\
\text { phosphates (e.g. laundry } \\
\text { detergents). }\end{array}$ \\
\hline
\end{tabular}




\begin{tabular}{|c|c|c|c|}
\hline PRESSURE & $\begin{array}{l}\text { IMPACTS (SOCIAL/ } \\
\text { ENVIRONMENTAL) }\end{array}$ & $\begin{array}{c}\text { GLOBAL AND REGIONAL } \\
\text { RESPONSES }\end{array}$ & $\begin{array}{c}\text { NATIONAL LEGISLATIVE } \\
\text { RESPONSES }\end{array}$ \\
\hline & & $\begin{array}{l}\text { Atlantic; EC Water } \\
\text { Framework Directive. } \\
\text { Caribbean } \\
\text { Cartagena Convention on the } \\
\text { Marine Environment. }\end{array}$ & \\
\hline $\begin{array}{l}\text { Increased atmospheric } \\
\text { emissions } \\
\text { These arise from a number } \\
\text { of sources, including } \\
\text { emissions from power } \\
\text { plants and industries, } \\
\text { vehicles and evaporation } \\
\text { from animal manure and } \\
\text { fertilizers. }\end{array}$ & $\begin{array}{l}\text { Oxygen depletion in } \\
\text { marine waters. } \\
\text { Global warming and } \\
\text { climate change. }\end{array}$ & $\begin{array}{l}\text { Global } \\
\text { UN Framework } \\
\text { Convention on Climate } \\
\text { Change and Kyoto } \\
\text { Protocol. }\end{array}$ & $\begin{array}{l}\text { - Permit systems for atmospheric } \\
\text { discharges } \\
\text { - Duties to use clean technologies; } \\
\text { - Emissions trading. }\end{array}$ \\
\hline $\begin{array}{l}\text { Other sources of } \\
\text { pollution } \\
\text { These include litter and } \\
\text { pollution arising from } \\
\text { activities within marine waters } \\
\text { such as aquaculture. }\end{array}$ & $\begin{array}{l}\text { Aesthetic impacts on } \\
\text { coastal areas with } \\
\text { impacts on tourism. } \\
\text { Decrease in water } \\
\text { quality with } \\
\text { consequential impacts } \\
\text { on fisheries and } \\
\text { biodiversity. }\end{array}$ & & $\begin{array}{l}\text { - } \quad \text { Effluent standards; } \\
\text { - Permitting systems; } \\
\text { - } \quad \text { Voluntary codes of conduct for } \\
\text { responsible aquaculture. }\end{array}$ \\
\hline
\end{tabular}




\begin{tabular}{|c|c|c|c|}
\hline PRESSURE & $\begin{array}{l}\text { IMPACTS (SOCIAL/ } \\
\text { ENVIRONMENTAL) }\end{array}$ & $\begin{array}{c}\text { GLOBAL AND REGIONAL } \\
\text { RESPONSES }\end{array}$ & $\begin{array}{c}\text { NATIONAL LEGISLATIVE } \\
\text { RESPONSES }\end{array}$ \\
\hline \multicolumn{4}{|c|}{ 2. Physical Alteration and Destruction of Habitats } \\
\hline $\begin{array}{l}\text { Infrastructural } \\
\text { development in coastal } \\
\text { areas } \\
\text { Increases in coastal } \\
\text { populations, urbanization, } \\
\text { industrialization, and tourism } \\
\text { are creating intense pressures } \\
\text { to change physical land forms } \\
\text { in coastal areas and build } \\
\text { infrastructure. }\end{array}$ & $\begin{array}{l}\text { Loss of habitats for } \\
\text { indigenous species, } \\
\text { e.g. mangroves, with } \\
\text { consequential impacts } \\
\text { on biodiversity, } \\
\text { livelihoods and tourism. } \\
\text { Increased or altered } \\
\text { flows of sediment. } \\
\text { Decreases in sediment } \\
\text { exacerbate coastal } \\
\text { erosion }\end{array}$ & & $\begin{array}{l}\text { - } \quad \text { Introduction of coastal plans; } \\
\text { - } \quad \text { Suffer zones; } \\
\text { - } \quad \text { Building codes; } \\
\text { - } \quad \text { Prohibitions/restrictions on } \\
\text { developments that are not coast- } \\
\text { dependent or are harmful; } \\
\text { - Integration of coast concerns } \\
\text { into land-use planning and } \\
\text { development control regimes; } \\
\text { - EIAs; } \\
\text { - Zoning; } \\
\text { Linking issuing of permits to } \\
\text { attainment of planning } \\
\text { objectives. }\end{array}$ \\
\hline $\begin{array}{l}\text { Physical alteration of } \\
\text { coastal water sheds } \\
\text { This typically arises from } \\
\text { deforestation, mining, } \\
\text { intensive agriculture or } \\
\text { infrastructural developments } \\
\text { that affect the flow, sediment }\end{array}$ & $\begin{array}{l}\text { Increased sediment is a } \\
\text { major threat to coral } \\
\text { reefs and marine } \\
\text { ecosystems }\end{array}$ & $\begin{array}{l}\text { Global } \\
1997 \text { UN Convention on } \\
\text { the Law of International } \\
\text { Watercourses } \\
\text { Recommendation of the } \\
\text { World Commission on }\end{array}$ & $\begin{array}{l}\text { Integration of coast concerns } \\
\text { into land-use planning and } \\
\text { development control regimes; } \\
\text { EIAs for activities affecting the } \\
\text { flow of rivers, the conversion of } \\
\text { virgin land, large scale irrigation } \\
\text { projects, etc.; }\end{array}$ \\
\hline
\end{tabular}




\begin{tabular}{|c|c|c|c|}
\hline PRESSURE & $\begin{array}{l}\text { IMPACTS (SOCIAL/ } \\
\text { ENVIRONMENTAL) }\end{array}$ & $\begin{array}{l}\text { GLOBAL AND REGIONAL } \\
\text { RESPONSES }\end{array}$ & $\begin{array}{c}\text { NATIONAL LEGISLATIVE } \\
\text { RESPONSES }\end{array}$ \\
\hline load or water quality of rivers. & & $\begin{array}{l}\text { Dams. } \\
\text { Regional } \\
\text { Europe: } 1992 \text { UNECE } \\
\text { Convention on } \\
\text { Transboundary Watercourses } \\
\text { and Lakes Convention; } \\
\text { Africa SADC Protocol on } \\
\text { Shared Watercourses; } \\
\text { Numerous treaties worldwide } \\
\text { dealing with specific rivers and } \\
\text { lakes; } \\
\text { Establishment of joint basin } \\
\text { management institutions. }\end{array}$ & $\begin{array}{l}\text { - Water abstraction permits; } \\
\text { - Catchment basin approach to } \\
\text { water management; }\end{array}$ \\
\hline $\begin{array}{l}\text { 3. Over-exploitation of } \\
\text { Living Resources }\end{array}$ & $\begin{array}{l}\text { Long term and } \\
\text { sometimes irreversible } \\
\text { decline in fish stocks } \\
\text { with associated impacts } \\
\text { on ecosystems and } \\
\text { fishing communities }\end{array}$ & $\begin{array}{l}\text { Global } \\
\text { UNCLOS } 1982 \\
1995 \text { UN Fish Stocks } \\
\text { Agreement; } \\
1993 \text { FAO Compliance } \\
\text { Agreement; } \\
\text { 1995 FAO Code of } \\
\text { Conduct for Responsible } \\
\text { Fisheries; }\end{array}$ & $\begin{array}{l}\text { - Prohibitions and licensing } \\
\text { systems for fisheries; } \\
\text { - Fisheries management plans; } \\
\text { - Marine biodiversity management } \\
\text { plans. }\end{array}$ \\
\hline
\end{tabular}




\begin{tabular}{|c|c|c|c|}
\hline PRESSURE & $\begin{array}{l}\text { IMPACTS (SOCIAL/ } \\
\text { ENVIRONMENTAL) }\end{array}$ & $\begin{array}{l}\text { GLOBAL AND REGIONAL } \\
\text { RESPONSES }\end{array}$ & $\begin{array}{c}\text { NATIONAL LEGISLATIVE } \\
\text { RESPONSES }\end{array}$ \\
\hline & & $\begin{array}{l}\text { International Plans of } \\
\text { Action to: (a) reduce } \\
\text { incidental catch of sea } \\
\text { birds in long line fisheries; } \\
\text { (b) conserve and manage } \\
\text { sharks; (c) to manage } \\
\text { fishing capacity; and (d) to } \\
\text { prevent, deter and } \\
\text { eliminate illegal, } \\
\text { unreported and } \\
\text { unregulated fishing; } \\
\text { 2001 FAO Reykjavik } \\
\text { Declaration on } \\
\text { Responsible Fisheries in } \\
\text { the Marine Ecosystem. } \\
\text { Regional } \\
\text { Numernous regional } \\
\text { fisheries agreements }\end{array}$ & \\
\hline
\end{tabular}




\begin{tabular}{|c|c|c|c|}
\hline PRESSURE & $\begin{array}{l}\text { IMPACTS (SOCIAL/ } \\
\text { ENVIRONMENTAL) }\end{array}$ & $\begin{array}{l}\text { GLOBAL AND REGIONAL } \\
\text { RESPONSES }\end{array}$ & $\begin{array}{l}\text { NATIONAL LEGISLATIVE } \\
\text { RESPONSES }\end{array}$ \\
\hline $\begin{array}{l}\text { 4. Excessive } \\
\text { exploitation of non- } \\
\text { living resources } \\
\text { This pressure is usually closely } \\
\text { associated with the physical } \\
\text { alteration of habitats ( } 2 \\
\text { above) and arises particularly } \\
\text { from excessive consumption } \\
\text { of water, mining, and water- } \\
\text { shed erosion. }\end{array}$ & $\begin{array}{l}\text { Excessive consumption } \\
\text { of fresh water reduces } \\
\text { river flows to coastal } \\
\text { areas resulting in } \\
\text { increased estuary salinity, } \\
\text { decreased fish yields, } \\
\text { decreased sedimentation, } \\
\text { salt water intrusion into } \\
\text { groundwater, etc. }\end{array}$ & $\begin{array}{l}\text { Global } \\
1997 \text { UN Convention on } \\
\text { the Law of International } \\
\text { Watercourses; } \\
\text { Development of equitable } \\
\text { utilization principle; } \\
\text { Recommendation of the } \\
\text { World Commission on } \\
\text { Dams. } \\
\text { Regional } \\
\text { Europe: 1992 UNECE } \\
\text { Convention on } \\
\text { Transboundary } \\
\text { Watercourses and Lakes } \\
\text { Convention; } \\
\text { Africa SADC Protocol on } \\
\text { Shared Watercourses; } \\
\text { Numerous treaties } \\
\text { worldwide dealing with } \\
\text { specific rivers and lakes. }\end{array}$ & $\begin{array}{l}\text { - Reorganization of water } \\
\text { management on catchment/ } \\
\text { watershed basis; } \\
\text { - Introduction of permitting and } \\
\text { pricing systems to reduce water } \\
\text { consumption; } \\
\text { - Identifying and maintaining } \\
\text { minimum water flow to protect } \\
\text { ecosystems. }\end{array}$ \\
\hline
\end{tabular}




\begin{tabular}{|c|c|c|c|}
\hline PRESSURE & $\begin{array}{l}\text { IMPACTS (SOCIAL/ } \\
\text { ENVIRONMENTAL) }\end{array}$ & $\begin{array}{c}\text { GLOBAL AND REGIONAL } \\
\text { RESPONSES }\end{array}$ & $\begin{array}{l}\text { NATIONAL LEGISLATIVE } \\
\text { RESPONSES }\end{array}$ \\
\hline $\begin{array}{l}\text { 5. Global climate } \\
\text { change } \\
\text { This is being caused primarily } \\
\text { by excessive emissions of } \\
\text { CO2 due to the fact that } \\
\text { industrialized and post- } \\
\text { industrial economies rely } \\
\text { heavily on oil, gas and coal for } \\
\text { energy. }\end{array}$ & $\begin{array}{l}\text { Resulting in flooding, } \\
\text { salination of agricultural } \\
\text { lands and freshwater } \\
\text { supplies and consequential } \\
\text { population displacement } \\
\text { and loss of habitats; } \\
\text { Destruction of coral } \\
\text { reefs from bleaching } \\
\text { (and possibly due to } \\
\text { increases in CO }{ }^{2} \\
\text { concentrations in water); } \\
\text { Increases in storms, } \\
\text { floods and natural } \\
\text { disturbances. }\end{array}$ & $\begin{array}{l}\text { Global } \\
\text { United Nations } \\
\text { Framework Convention on } \\
\text { Climate Change and Kyoto } \\
\text { Protocol. }\end{array}$ & $\begin{array}{l}\text { - Air pollution control legislation } \\
\text { Protection of sand dunes and } \\
\text { other coastal land forms through } \\
\text { establishment of buffer zones, } \\
\text { restrictions on coastal buildings, } \\
\text { etc.; } \\
\text { - Planning for "managed retreat" } \\
\text { and hazard responses. }\end{array}$ \\
\hline $\begin{array}{l}\text { 6. Introduction of } \\
\text { exotic species } \\
\text { This occurs particularly due to } \\
\text { ships' transporting ballast } \\
\text { water and sediments around } \\
\text { the world and the rapid } \\
\text { increase in aquaculture. }\end{array}$ & $\begin{array}{l}\text { Degradation of } \\
\text { ecosystems by alien } \\
\text { invasive species. Human } \\
\text { health impacts from } \\
\text { pathogens (e.g. cholera). } \\
\text { Consequential socio- } \\
\text { economic impacts, } \\
\text { e.g. from reduction in } \\
\text { fisheries. }\end{array}$ & $\begin{array}{l}\text { Global } \\
\text { Convention on Biological } \\
\text { Diversity and Cartagena } \\
\text { Protocol on Biosafety; } \\
\text { Draft IMO Convention on } \\
\text { Ballast Water. }\end{array}$ & $\begin{array}{l}\text { - Restrictions on the movement of } \\
\text { fish and other aquatic organisms. } \\
\text { - Mandatory ballast water } \\
\text { practices imposed by port states. }\end{array}$ \\
\hline
\end{tabular}




\section{ICM PRINCIPLES}

\subsection{Nature and Importance of Principles}

The governance of human users of coastal areas is at the heart of ICM, as discussed in chapter 1. Governance systems are ultimately based on fundamental values. These values give rise to structured sets of propositions that can be used to evaluate human conduct. These general propositions are usually referred to as principles.

Any ICM programme will be based on a theory that includes various values, even if they are not expressly mentioned in the programme. For example, an ICM programme will typically be based on underlying values common to many pubic issues, such as: the common good, fairness, and stewardship of the environment. Principles might be more specific and explicit, identifying coastal dwellers as requiring fair treatment and coastal wildlife and its habitat as deserving particular protection. The use of a particular method of evaluation, such as EIA or cost-benefit analysis, may be adopted as a principle.

It is very beneficial to articulate and define as clearly as possible the core principles underlying a proposed ICM management regime at an early stage in the process of developing an ICM policy or programme. This has a number of advantages. Firstly, it clarifies thinking and ensures that the core principles, on which the entire management system will be based, are shared. Although it may take some time to reach a consensus on these fundamental issues, once reached it will make agreement on the details much easier and quicker.

Secondly, reaching agreement on the core principles early on in a process also makes it much easier to resolve later conflicts between stakeholders because the agreed set of principles can be used as a yardstick or point of reference. In other words the "best" outcome can be determined by deciding which of the possible outcomes is most consistent with the pre-agreed principles.

It is also important to appreciate that there are different kinds of principles. Some fundamental principles may be pure value judgements that are incapable of being proved scientifically or deduced from experience. Examples include the principle that all people should be treated fairly or the principle that all forms of life are intrinsically valuable. However in the ICM context principles are more often distilled from experience. The European 
Union, for example, in formulating its approach to ICM examined the findings of a number of coastal "demonstration projects" conducted in different countries and under diverse circumstances in order to determine which approaches worked and which did not. These findings were then used to draw general conclusions about how ICM should be implemented which were formulated into eight principles on which ICM in the EU should be based (see Box 5).

It is also important to distinguish principles from rules. A system of rules is used to determine a precise answer (usually about whether or not certain conduct is permissible) and should be structured in such a way that no two rules are contradictory. For example, a fisheries law may contain a rule to the effect that anyone who catches more than two tuna fish without a licence to do so, commits and offence and is liable to pay a fine. In order to apply this rule one must determine certain facts such as how many fish were caught, the species (i.e. whether or not they were tuna) and whether or not the fisher was in possession of a licence that authorized the catching of those fish. Once this has been done one can determine whether or not the rule has been contravened, and the consequence.

Principles tend to be far more general, and any one principle may conflict to some extent with other principles in the system. This means that in relation to each set of circumstances the decision-maker must first decide what principles are applicable, and then the importance (or weight) that should be given to each principle. Finally the decision-maker must use his or her subjective judgement to balance all the relevant principles to reach a decision that gives best effect to the overall purpose of the set of principles. For example, an ICM programme may require a decision-maker to apply a set of principles that includes: creating livelihoods for poor coastal communities, maintaining the ecological integrity of the coast, and protecting the interests of current and future generations. Unlike rules, these principles do not give a precise answer to any particular decision, such as whether or not the construction of a factory in a coastal area should be authorized. Indeed, if one applies the principle concerning livelihood creation in isolation it may suggest that the factory should be authorized, while applying the ecological integrity principle in isolation may result in the opposite conclusion. However principles have the advantage that they are more general and can be applied to a range of situations (including unforeseen circumstances) whereas rules tend to apply to a narrowly defined range of circumstances. The rule discussed above, for example, applies only to the catching of tuna fish. 
Principles are particularly useful in relation to ICM because:

- they can be used to articulate the most important aspects of an ICM programme in a clear and accessible way;

- their general nature enables the same set of principles to be applied in diverse circumstances which make them an appropriate means of addressing the infinite diversity and complexity of coastal issues and circumstances;

- the flexibility inherent in applying a set of principles allows decisions to be adapted to particular circumstances while maintaining a focus on achieving the overall purpose; and

- the principles almost always apply across sectors and can have a powerful integrating effect because if applied in a balanced way they tend to produce decisions which are consistent with the overall purpose or core values of the ICM programme even if the decisions are made by different sectoral agencies.

Principles can be used in many ways but in this context it is useful to distinguish between the broad set of principles that may be used to describe ICM and how it is to be conducted, and a narrower set of more precisely defined principles which may be used in ICM legislation. In this publication the former principles are referred to as "management principles" and the latter as "legal principles".

\subsection{Management Principles}

Many principles of ICM that are not suitable for inclusion in legislation in the form of legally enforceable principles nevertheless play a very important role in shaping ICM legislation. As discussed in section 4.3, at the outset of any ICM legislative reform process it is important to identify the principles that will guide the design of the legal and institutional framework. It is particularly important that any new legislative reforms are guided by the management principles of the ICM initiative as a whole in order to ensure the development of a legal framework that is appropriate for ICM. This means that the drafters of ICM legislation must not only be skilled in the art of legislative drafting, they must also understand, and be guided by, the core management principles of ICM such as those discussed in this section.

At the international level one of the most important developments over the last decade has been a shift towards the "ecosystem approach" to environmental management. The Conference of the Parties to the 
Convention on Biological Diversity (COP) endorsed this approach at its Fifth Meeting in Nairobi, in May 2000 ${ }^{17}$. The Annex to the resolution of the COP includes: a description of the ecosystem approach, lists 12 complementary and inter-linked principles of the ecosystem approach and a section entitled "operational guidance for the application of the ecosystem approach" (these are reproduced in Annex 1). The Annex describes the ecosystem approach as "a strategy for the integrated management of land, water and living resources that promotes conservation and sustainable use in an equitable way."

As its name suggests, the ecosystem approach is based on the understanding that ecosystems must be understood and treated as complex, dynamic systems which we do not fully understand. As systems, they cannot be understood by applying a reductionist approach of attempting to analyse each of the part of aspects in order to understand how the whole system works. The ecosystem must be studied as a whole with particular emphasis on looking at "the essential structure, processes, functions and interactions among organisms and their environment". In other words, the focus is on understanding the web of relationships that determine how the system functions in order to understand how this will affect the functioning of any single part. Furthermore people are understood as being an integral component of any ecosystem in which they are present, rather than as external observers, beneficiaries or managers of the ecosystem.

Although the ecosystem approach as described in Annex 1 is intended to relate to the conservation of biological diversity under the umbrella of the $\mathrm{CBD}$, the similarities between it and the ICM approach are immediately apparent from a reading of the principles. Certainly many ICM practitioners would subscribe to the following statements of principles that underpin the ecosystem approach:

- ecosystems (and coastal areas) should be managed in a fair and equitable way for their intrinsic value and for the benefits for humans;

- management should be decentralization to the lowest appropriate level in order to increase efficiency, effectiveness and equity;

$17 \mathrm{UNEP} / \mathrm{CBD} / \mathrm{COP} / 5 / 23$ Decision V/6 Ecosystem Approach. 
- those aspects of the economic system that work against ecosystem management objectives should be changed where possible (e.g. by reducing market distortions, eliminating perverse incentives, aligning economic incentives with management goals and internalizing costs and benefits as far as possible so that the costs of conservation are borne by the polluters or main beneficiaries of the ecosystem).

- the conservation of the integrity (structure and functioning) of the ecosystem must be prioritized in order to maintain the services which it supplies; which implies a cautious management approach that avoids exceeding the limits of the system;

- appropriate temporal and spatial scales must be used so that long-term as well as short-term objectives are achieved and the interrelationships with other ecosystems are considered;

- adaptive management techniques should be used so that it is easier to respond to the inevitable changes (many of which are likely to be unpredictable) inherent in the functioning of complex natural systems; and

- all forms of relevant information and expertise must be used (e.g. indigenous and local knowledge as well as scientific information) and all sectors of society and relevant disciplines must be involved.

The ecosystem approach represents an important milestone on the road to realising that the principles of ICM are for the most part relevant to regulating the relationship between humans and the environment anywhere. The main reason for this is because the ICM approach seeks to adapt its approach to governance to accord with the natural characteristics of coastal ecosystems (see Box 9). Coastal ecosystems are simply a particular subcategory of ecosystem and hence it is not surprising that there is a high degree of consistency between the ecosystem and ICM approaches. Probably the main reason that the ICM approach developed ahead of the wider ecosystem approach, is that the regulatory deficiencies which the ecosystem approach seeks to address arose in particularly intense forms in coastal areas. Coastal areas are both ecologically highly valuable and places where particularly intensive and diverse human activities occur. 
In 2002 the WSSD in Johannesburg endorsed the ecosystem approach as a key means of achieving sustainable development of the oceans and sustainable fisheries management. In particular it encouraged:

"the application by 2010 of the ecosystem approach, noting the Reykjavik Declaration on Responsible Fisheries in the Marine Ecosystem ${ }^{18}$ and decision $\mathrm{V} / 6$ of the Conference of the Parties to the Convention on Biological Diversity ${ }^{19 " .}$

The ecosystem approach has also been adopted in relation to coastal management at a regional level by the European Community (see Box 5), and in national legislation. For example the Oceans Act, 1996 of Canada states in its preamble:

"WHEREAS Canada holds that conservation, based on an ecosystem approach, is of fundamental importance to maintaining biological diversity and productivity in the marine environment;" (emphasis added).

18 See Food and Agriculture Organization of the United Nations document C200/INF/25, Appendix I.

19 See UNEP/CBD/COP/5/23, Annex III. 


\section{Box 4}

\section{RECOMMENDATION OF THE EUROPEAN PARLIAMENT AND OF THE COUNCIL OF 30 MAY 2002 CONCERNING THE IMPLEMENTATION OF INTEGRATED COASTAL ZONE MANAGEMENT IN EUROPE $(2002 / 413 / \mathrm{EC})$}

The document recommends that Member States "take a strategic approach to the management of their coastal zones, based on:

(a) protection of the coastal environment, based on an ecosystem approach preserving its integrity and functioning, and sustainable management of the natural resources of both the marine and terrestrial components of the coastal zone;

(b) recognition of the threat to coastal zones posed by climate change and of the dangers entailed by the rise in sea level and increasing frequency and violence of storms;

(c) appropriate and ecologically responsible coastal protection measures, including protection of coastal settlements and their cultural heritage;

(d) sustainable economic opportunities and employment options;

(e) a functioning social and cultural system in local communities;

(f) adequate accessible land for the public, both for recreational purposes and aesthetic reasons;

(g) in the case of remote coastal communities, maintenance or promotion of their cohesion;

(h) improved co-ordination of the actions taken by all the authorities concerned, both at sea and on land, in managing the sea-land interaction."

Chapter II of the recommendation concerns the principles on which national

ICM strategies and measures should be based and recommends that:

"Coastal zone management should be based on:

(a) a broad overall perspective (thematic and geographical) which will take into account the interdependence and disparity of natural systems and human activities with an impact on coastal areas;

(b) a long term perspective which will take into account the precautionary principle and the needs of present and future generations;

(c) adaptive management during a gradual process which will facilitate adjustment as problems and knowledge develop. This implies the need for a sound scientific basis concerning the evolution of the coastal zone;

(d) local specificity and the great diversity of European coastal zones which will make it possible to respond to their practical needs, specific solutions and flexible measures; 
(e) working with natural processes and respecting the carrying capacity of ecosystems, which will make human activities more environmentally friendly, socially responsible and economically sound in the long run;

(f) involving all the parties concerned (economic and social partners, the organisations representing coastal zone residents, non-governmental organisations and the business sector) in the management process, for example by means of agreements and based on shared responsibility;

(g) support and involvement of relevant administrative bodies at national, regional and local level between which appropriate links should be established or maintained with the aim of improving co-ordination of the various existing policies. Partnership with and between regional and local authorities should apply when appropriate;

(h) use of a combination of instruments designed to facilitate coherence between sectoral policy objectives and coherence between planning and management."

Chapter III recommends that Member States conduct or update an overall stocktaking to analyse which major actors, laws and institutions influence the management of their coastal zones. Chapter IV recommends that Member States should develop a national strategy or strategies to implement the principles for integrated management of the coastal zone, based on the result of the stocktaking. It also specifies the minimum content of the strategies. The Council recommends that these strategies should "develop or maintain national and, where appropriate, regional or local legislation or policies and programmes which address both the marine and terrestrial areas of coastal zones together" and in particular should identify measures to promote bottom-up initiatives and public participation in ICM.

The recommendation also encourages Member States to co-operate with neighbouring countries including non-Member States in the same regional sea, and to work actively with the community institutions and other coastal stakeholders to facilitate progress towards a common approach to integrated coastal zone management. Member States are required to report to the Commission on their experiences in implementing the recommendation 45 months after its adoption.

\subsection{Legal Principles}

As discussed in the previous section, most ICM principles do not appear in legislation as principles, even though they may have played an important role in shaping that legislation. However certain principles that are capable of being defined reasonably clearly are found in ICM legislation. In some case the legislation states the principle itself and obliges officials to take account 
of it when making decisions that affect the coast. In most cases the principle is not stated as a principle but may be deduced from the legal mechanisms in the legislation that are designed to give effect to it. For example, the polluter pays principle may not be expressed as a principle but its application may be clear from provisions that hold anyone who damages the environment liable for paying for the damage to be rectified.

The relevant principles in national law are often contained in framework environmental legislation and do not apply only to coastal areas. The majority of these originate in international legal instruments, particularly those dealing with shared natural resources and are discussed in chapter 3. This section discusses some examples of legal principles in national legislation that are intended to apply particularly to coastal areas.

In identifying appropriate legal principles to support ICM it is also important not to overlook potentially useful legal principles that existed previously in the legal system or in unwritten customary law but which have been overruled by later legislation, abrogated by disuse, or weakened over time. For example, the Preamble to Spanish Shores Act No. 22/1988, points out that one of the innovative aspects of the Act was: "the restoration to their full purity of principles deeply rooted in our historical law which have been weakened in the course of their application". An example of this is the reaffirmation in section 7 of the Act of the Roman and Medieval law principle that the sea and the seashore are inalienable public property (i.e. incapable of being owned privately).

\subsubsection{Seashore and Sea as Public Property}

The legal systems of many countries recognize the seashore (variously defined but at a minimum the inter-tidal zone) as having a special legal status, typically as a form of common public property. Usually this special status means that the seashore cannot be sold, and that the general public has a right to use this area for certain purposes (e.g. fishing and recreation) and has limited rights to traverse adjacent private property to gain access to, or to move along, the seashore. 
The Romans recognized the sea and seashore extending as far inland as was reached by the highest winter waves ${ }^{20}$, as a public commons that was not capable of being appropriated for private purposes. Roman law classified the sea and sea-shore as the common property of everyone (res omnium communes). Roman-Dutch law re-classified this area as res publicae, meaning that it was owned by the State but as custodian for the people. Variations on the original Roman law concept have survived in both civil law legal systems ${ }^{21}$ (e.g. the concept of public domain) and in common law jurisdiction ${ }^{22}$ (e.g. the American law application of the public trust doctrine to coastal areas), although often in a more or less diluted form. However, more recently ICM initiatives to protect coastlines has led to this ancient principle being reasserted in a number of jurisdictions including Costa Rica, France and its overseas dominions (Guyana, Guadeloupe and Martinique in the Caribbean and Réunion in the Indian Ocean), Peru, Spain, and Sri Lanka ${ }^{23}$.

Similar concepts also exist in countries with other legal traditions. For example the Scandinavian concept of "Everyman's right" which preserves the rights of the public to use coastal areas has survived to the present day in countries such as Finland, Norway and Sweden (see Box 14).

Reasserting the public character of coastal areas in a legally enforceable form is often the cornerstone of ICM initiatives. Legal recognition of the special status of the coast as a public common of some form provides a basis and rationale for introducing a variety of other important legal mechanisms to support ICM. For example, this status provides a justification for: establishing decision-making procedures that prioritizie the common good over private or sectoral interests; prioritizing the conservation of coastal ecosystems (particularly for future generations); and using funds generated from the use of coastal assets to protect and enhance the coast as a public asset.

20 Est autem litus maris quatenus bybernus fluctus maximus excurrit.

21 For example, Belgium, France (domain publique), Germany, Greece, Italy (demanio pubblico), Spain (dominio público marítimo-terrestre), Thailand.

22 For example, England and Wales, Scotland, South Africa, United States of America, and many Caribbean States.

23 See section 5.2.3 for a discussion of public ownership as a mechanism to achieve ICM objectives. 


\subsubsection{Prioritization of Coast-Dependent Development}

This principle can be regarded as a coastal-specific application of the idea that natural resources should be rationally utilised. Globally, competition to use limited coastal resources is escalating rapidly (often at least partially caused by a demographic shift of population towards the coast). This principle provides a rational first step in the process of allocating those resources by giving added weight to uses that by their very nature are dependent on inherent attributes of the coastal zone.

The principle is expressed in the US Congressional Declaration of Coastal Zone Policy and is also found in the legislation of several other countries. For example, the 1988 Spanish Shores Act provides that: "Generally, only works, installations and activities which by their very nature may not be located elsewhere or which provide services necessary or convenient for the use of the coastal public property will be permitted ..." [within a 100 meters wide strip immediately inland of the seashore]. 


\section{INFLUENCE OF INTERNATIONAL LAW AND POLICY}

\subsection{International and Regional Context for National ICM}

The seas and oceans that cover most of our planet give coastal areas their distinct characteristics. They also connect the coastal environments in each country to those within other countries and within areas beyond the limits of national jurisdiction like the high seas. This means that the management of any coastal area must take account of the wider ecosystems in which that area is situated as well as influences originating outside the area, such as ocean currents and weather patterns. Similarly, it is important for anyone involved in developing national legal and policy frameworks for ICM to appreciate that the national governance systems need to take account of a wider context of international law, so-called "soft law" instruments like nonbinding declarations, and international and regional initiatives.

International law may require a country to take certain measures by virtue of it being party to a legally binding treaty such as the Convention on Biological Diversity or the 1982 United Nations Convention on the Law of the Sea (UNCLOS). Designers or reformers of legal frameworks for ICM must be conscious of these requirements at all times. In addition, the principles, standards and recommendations contained in non-binding international declarations, such as Chapter 17 of Agenda 21 or the FAO Code of Conduct for Responsible Fisheries, can provide extremely valuable guidance because many of the international coastal issues which they deal with are equally relevant to national coastal management. Furthermore, the standards and approaches recommended in such documents or by international or regional organizations and initiatives often reflect a wide consensus on what constitutes best practice, and can therefore serve as a valuable means of measuring and evaluating national frameworks for ICM.

\subsection{Evolution of ICM as a Matter of International Concern}

The international community first recognized that coastal areas required special protection at the United Nations Conference on the Human Environment held in Stockholm in 1972 (the same year as the Federal Coastal Zone Management Act in the USA was enacted). The action plan 
adopted by the Conference ${ }^{24}$ recommended that coastal zones be protected, particularly those which were not yet degraded. This was followed by a recommendation in the 1987 report of the World Commission on Environment and Development (the Brundtland report) that assistance be given to developing countries "to strengthen their legal and institutional frameworks needed for integrated management of coastal resources"25.

Since the 1972 Stockholm Conference the fundamental objective of the international community in the environmental field has evolved from environment protection to the broader objective of sustainable development. The idea of sustainable development was first given international prominence by the Brundtland report and was a cornerstone of the 1992 United Nations Conference on Environment and Development (UNCED) in Rio de Janeiro. By the time the successor conference to UNCED took place in Johannesburg, South Africa, a decade later, the sustainable development approach had become the new orthodoxy and the conference was entitled the World Summit on Sustainable Development (WSSD).

Principle 27 of the 1992 Rio Declaration refers to the "further development of international law in the field of sustainable development". Although the meaning of the term "sustainable development" is notoriously ambiguous and unclear, it has undoubtedly had, and continues to have, a profound effect on the development of international law. The significance of the widespread adoption of sustainable development as an over-arching policy goal at the international level (as well as by regional organizations and national governments), is that it, like ICM, is based on an interdisciplinary, integrative approach which is concerned with both development and the conservation and enhancement of the natural environment. As one writer has pointed out "ICM and sustainable development are now viewed as inherent and necessary components of each other"26.

24 See the Declaration of Principles, the Action Plan and the Report of the Conference, 1972 UN Document A/Conf. 48/14/Rev. 1. [11 International Legal Materials 1416]

25 Our Common Future, WCED, Oxford, 1987, p. 226.

26 Vallega, A. 1993. A Conceptual Approach to Integrated Coastal Management, Ocean \& Coastal Management 21, sections 149-162, p. 150. 
However it is important to note that despite the considerable overlap between the field of international environmental law (the use of international law to address environmental issues) and international law aimed at sustainable development, there are important differences. Some environmental issues are not related to development, and in some cases the concern might be to protect species or ecosystems from all forms of development ${ }^{27}$. This distinction is an important one when drafting national legislation since it is often assumed that if the object or purpose of the legislation is defined to be the achievement of "sustainable development" this will encompass all environmental protection objectives as well.

The challenge posed by the warming of the atmosphere and the consequential changes in the world's climate and rise in sea level has played an important role in intensifying the focus on ICM at the international level. In order to reduce the risks and minimize potential harm caused by the predicted acceleration in sea level rise, comprehensive long term planning is essential. Sectoral approaches which do not manage coastal areas as an integrated system are clearly inadequate and inappropriate to deal with a challenge of this magnitude.

\subsection{Importance of "Soft Law"}

The term "soft law" has been coined to refer to the many non-binding international instruments such as declarations of principles, codes of practice, recommendations, guidelines, resolutions and standards that have proliferated, particularly in the environmental field, during the last few decades. Many lawyers dislike the term since it is usually understood that the fundamental characteristic of law that distinguishes it from other social rules is that it is binding and enforceable, and hence the term "soft law" is a contradiction in terms. Despite the limitations of the term itself, we have used it as a convenient collective noun for the many types of international and regional statements that do not in themselves impose a legally binding obligation on a country. This category includes, for example, the World Charter for Nature $(1982)^{28}$, the Rio Principles ${ }^{29}$,

27 Birnie and Boyle, 2002 at pp. 2 and 3.

28 United Nations General Assembly Resolution 37/7.

29 Rio de Janeiro Declaration on Environment and Development, 16 June 1992. 
Agenda $21^{30}$, and the FAO Code of Conduct for Responsible Fisheries ${ }^{31}$, the Jakarta Mandate ${ }^{32}$, and the Johannesburg Action Plan ${ }^{33}$.

Despite its non-binding nature, soft law is extremely important in the field of ICM, for the following reasons.

It is easier and faster to reach agreement on complex and novel issues of international concern if the result is a document that is not legally binding. Countries are more amenable to reaching consensus on detailed measures or approaches, and less inclined to spend excessive amounts of time negotiating compromises and ambiguous wording if they know in advance that they cannot be held legally accountable.

The process of developing soft law instruments inevitably results in on-going exchanges of information and promotes the emergence of common understandings and approaches.

States that participate in the development of soft law instruments are consciously seeking to influence the development of international practice or law. States which indicate their support for these instruments then effectively assume a good faith commitment to implementing them or to follow the recommendations which they contain, and in so doing usually modify their behaviour accordingly.

Soft law documents do have differing degrees of authority even if they are not legally binding, and they frequently facilitate the emergence of "hard-law" obligations, either in the form of new treaty obligations or new rules of customary international law. For example, it is clear that the FAO Code of Conduct for Responsible Fisheries and the more recent international plans

\footnotetext{
30 Agenda 21, 16 June 1992, Rio de Janeiro. For example, Chapter 8 deals with the importance of providing an effective legal and regulatory framework and Chapter 17 deals with the protection of oceans, seas and coastal areas.

31 Code of Conduct for Responsible Fisheries, 31 October 1995, Rome. Article 10 of the Code deals specifically with the integration of fisheries into coastal area management.

32 Convention on Biological Diversity (available at www.biodiv.org).

33 Report on the World Summit on Sustainable Development A/CONF. 199/20.
} 
of action $^{34}$ are succeeding in establishing new norms of acceptable international behaviour and in developing common approaches to these issues. This process has been supported by the development of technical guidelines to support the implementation of the Code of Conduct (including guidelines on the integration of fisheries into coastal area management). The decisions of the Conferences of the Parties to the Convention on Biological Diversity and the Ramsar Convention play a similar role.

A number of international soft law documents encourage states to adopt ICM, including Agenda 21, the "Jakarta mandate" Decision of the Conference of the Parties to the Convention on Biological Diversity, the FAO Code of Conduct for Responsible Fisheries and the Johannesburg Plan of Action formulated by the WSSD (see Annex 2).

\subsection{Treaties}

International law may come into being in several ways, most notably by the custom of states or by virtue of a treaty ${ }^{35}$ between them. Treaties between more than two states (multilateral treaties) may either be confined to a particular geographical area (regional treaties) or may be global in scope.

\subsubsection{Global Treaties}

There is no global treaty that focuses primarily on coastal issues but the UN Framework Convention on Climate Change (UNFCCC) requires states to prepare integrated coastal zone management plans ${ }^{36}$. Several global

34 Dealing with reducing the incidental catch of seabirds in long-line fisheries; the conservation and management of sharks; the management of fishing capacity and the prevention, deterrence and elimination of illegal, unreported and unregulated fishing.

35 "Treaty" is the generic name given to all forms of international agreement entered into between states and includes conventions, and protocols to conventions and treaties. It is defined in the 1969 Vienna Convention on the Law of Treaties as follows: "treaty" means an international agreement concluded between States in written form and governed by international law, whether embodied in a single instrument or in two or more related instruments and whatever its particular designation.

36 UNFCCC, Article 4(1)(e). The Preamble also recognizes the need to combat the effects of sea-level rise on coastal areas. 
treaties deal specifically with marine issues, the most important of these from an ICM perspective being the UN Convention on the Law of the Sea (UNCLOS) $)^{37}$, and the conventions concerning marine pollution adopted under the auspices of the $\mathrm{IMO}^{38}$. Several other global treaties must also be taken into account because they deal with issues of importance to ICM. These include treaties dealing with:

- biological diversity and the conservation of wildlife and wildlife habitats (e.g. the Convention on Biological Diversity ${ }^{39}$, the Ramsar Convention on Wetlands of International Importance, and the Bonn Convention on the Conservation of Migratory Species of Wild Animals);

- cultural and natural heritage (1985 UNESCO Convention concerning the Protection of the World Cultural and Natural Heritage); and

- the movement and disposal of hazardous waste (e.g. the 1989 Basel Convention).

The following table gives an indication of some of the issues that typically arise when developing national legal frameworks for ICM and the treaties that should be taken into account when dealing with them.

37 United Nations Convention on the Law of the Sea, 10 December 1982, Montego Bay, which came into force on 16 November 1994.

38 The principal IMO Conventions relating to marine environmental protection are: The International Convention relating to Intervention on the High Seas in Cases of Oil Pollution Casualties (1969); International Convention on Civil Liability for Oil Pollution Damage (1969); International Convention on the Establishment of an International Fund for Compensation for Oil Pollution Damage (1971); London Convention on the Convention of Marine Pollution by Dumping of Wastes and Other Matter (1972); International Convention for the Prevention of Pollution from Ships (1973/78) (MARPOL); International Convention on Salvage (1989); International Convention on Oil Pollution Preparedness, Response and Co-operation (1990); International Convention on Liability and Compensation for Damage in Connection with the Carriage of Hazardous and Noxious Substances by Sea (1996); Protocol to the London Convention on the Prevention of Marine Pollution by Dumping of Waste and Other Matter (1996).

39 Convention on Biological Diversity, 5 June 1992, Rio de Janeiro, which came into force on 29 December 1993. 
Box 5

TREATIES RELEVANT TO KEY ICM ISSUES

\begin{tabular}{|c|c|}
\hline IsSUE & TREATY \\
\hline Scope of ICM & $\begin{array}{l}\text { UNCLOS } \\
\text { Defines marine areas (e.g. territorial sea, exclusive economic } \\
\text { zone) and jurisdiction of states, particulary in relation to } \\
\text { marine living resources }\end{array}$ \\
\hline \multirow[t]{4}{*}{ Coastal Planning } & $\begin{array}{l}\text { Convention on Biological Diversity } \\
\text { Requires preparation of national biological diversity } \\
\text { planning that will affect ICM planning. }\end{array}$ \\
\hline & $\begin{array}{l}\text { World Heritage Convention } \\
\text { Provides for the establishment and protection of world } \\
\text { heritage sites for natural and cultural heritage of } \\
\text { international significance. }\end{array}$ \\
\hline & $\begin{array}{l}\text { UNFCCC } \\
\text { Requires States to plan and take measure to address sea } \\
\text { level rise }\end{array}$ \\
\hline & $\begin{array}{l}\text { Regional Conventions } \\
\text { e.g. the Helsinki Convention requires the Parties to it to } \\
\text { establish coastal buffer zones to protect the Baltic sea area. }\end{array}$ \\
\hline \multicolumn{2}{|c|}{ Nature Conservation } \\
\hline & $\begin{array}{l}\text { UNCLOS } \\
\text { Duty to protect and preserve marine environment } \\
\text { (Part XII) }\end{array}$ \\
\hline \multirow[t]{5}{*}{ Protected Areas } & Convention on Biological Diversity \\
\hline & $\begin{array}{l}\text { Ramsar Convention on Wetlands } \\
\text { Ramsar site criteria }\end{array}$ \\
\hline & World Heritage Convention World Heritage site criteria \\
\hline & Bonn Convention on Migratory Species \\
\hline & UN Fish Stocks Agreement \\
\hline \multirow[t]{2}{*}{ Alien species } & Convention on Biological Diversity \\
\hline & Draft IMO Ballast Water Convention \\
\hline
\end{tabular}




\begin{tabular}{|l|l|}
\hline Pollution control \\
\hline $\begin{array}{l}\text { Land-based } \\
\text { pollution }\end{array}$ & $\begin{array}{l}\text { UNCLOS } \\
\text { Regional treaties and protocols }\end{array}$ \\
\hline $\begin{array}{l}\text { Marine Oil } \\
\text { pollution }\end{array}$ & IMO Conventions \\
\hline $\begin{array}{l}\text { Dumping and } \\
\text { incineration at } \\
\text { sea }\end{array}$ & $\begin{array}{l}\text { UNCLOS } \\
\text { London Dumping Convention (especially 1996 Protocol) }\end{array}$ \\
\hline $\begin{array}{l}\text { Waste and } \\
\text { hazardous } \\
\text { materials }\end{array}$ & $\begin{array}{l}\text { Basle Convention } \\
\text { Regional Conventions, e.g. Bamako Convention }\end{array}$ \\
\hline Development Control \\
\hline $\begin{array}{l}\text { Environmental } \\
\text { impact } \\
\text { assessment }\end{array}$ & Regional Conventions, e.g. Espoo Convention \\
\hline $\begin{array}{l}\text { Environmental } \\
\text { impact } \\
\text { assessment }\end{array}$ & UNCLOS \\
\hline $\begin{array}{l}\text { Transboundary } \\
\text { impacts }\end{array}$ & $\begin{array}{l}\text { Protocols to Regional Seas Conventions, e.g. Kuwait } \\
\text { Convention }\end{array}$ \\
\hline $\begin{array}{l}\text { Public } \\
\text { Participation }\end{array}$ & Regional Conventions, e.g. Aarhus Convention \\
\hline
\end{tabular}

\subsubsection{Regional Treaties}

Regional treaties and the various protocols, action plans, institutions and initiatives that they have created, have had a very significant impact on the development of ICM at the national level and in practice often have more relevance to national ICM initiatives than global treaties. Many started as treaties designed to address issues such as marine pollution or fisheries and have gradually evolved to encompass ICM. For example, when the UNEP Regional Seas Programme ${ }^{40}$ was initiated in 1972, the first programme was aimed primarily at addressing marine pollution issues in the Mediterranean.

40 The Programme covers 13 regions of which nine currently have binding international framework conventions and all have action plans. In addition five similar regional programmes have been established outside UNEP, covering the Antarctic, Arctic, Baltic, Caspian and North East Atlantic. 
In 197516 Mediterranean countries adopted the Mediterranean Action Plan (MAP), and in 1976 entered into the Convention for the Protection of the Mediterranean Sea against Pollution (the Barcelona Convention). The Convention was further developed by the addition of six protocols dealing with specific environmental issues ${ }^{41}$. In 1995 the Barcelona Convention was amended and renamed the Convention for the Protection of the Marine Environment and the Coastal Region of the Mediterranean to reflect the shift in emphasis towards addressing coastal and marine issues in an integrated manner. In the same year the original MAP was replaced by an Action Plan for the Protection of the Marine Environment and the Sustainable Development of the Coastal Areas of the Mediterranean (MAP Phase II).

Similarly the 1974 Helsinki Convention on the Protection of the Marine Environment of the Baltic Sea Area was intended "to prevent and abate pollution and to protect and enhance the marine environment of the Baltic Sea Area". Its 1992 successor has wider objectives and aims "to prevent and eliminate pollution in order to promote the ecological restoration of the Baltic Sea Area and the preservation of its ecological balance" and covers a range of new issues including environmental impact assessment, the conservation of nature and biological diversity, reporting and the exchange and public dissemination of information.

A full discussion of all of the relevant regional treaties is beyond the scope of this publication, but the following list of selected regional treaties arranged with reference to the region to which they relate, gives some idea of the range and scope of these treaties. Particular treaties are also discussed in more depth elsewhere in the text.

41 Protocol for the Prevention and Elimination of Pollution of the Mediterranean Sea by Dumping from Ships and Aircraft or incineration at Sea (1976); Protocol concerning Cooperation in Combating Pollution of the Mediterranean Sea by Oil and Other Harmful Substances in Cases of Emergency (1976, replaced by 2002 Valetta Protocol); Protocol for the Protection of the Mediterranean Sea against Pollution from Land-based Sources and Activities (1980); Protocol concerning Specially Protected Areas and Biological Diversity in the Mediterranean (1982); Protocol for the Protection of the Mediterranean Sea against Pollution resulting from Exploration and Exploitation of the Continental Shelf and the Seabed and its Subsoil (1994), Protocol on the Prevention of Pollution of the Mediterranean Sea by Transboundary Movements of Hazardous Wastes and their Disposal (1996). 


\section{Box 6}

A SELECTION OF REGIONAL TREATIES RELEVANT TO ICM

\begin{tabular}{|c|c|c|}
\hline Region & Treaty & Subject matter \\
\hline Europe & Berne Convention (1982) & $\begin{array}{l}\text { Conservation of European } \\
\text { wildlife and natural habitat }\end{array}$ \\
\hline Europe & Espoo Convention (1991) & $\begin{array}{l}\text { Environmental impact } \\
\text { assessment in a } \\
\text { transboundary context }\end{array}$ \\
\hline Europe & Aarhus Convention (1999) & $\begin{array}{l}\text { Access to information, } \\
\text { public participation in } \\
\text { decision-making, and access } \\
\text { to justice. }\end{array}$ \\
\hline Mediterranean Sea & $\begin{array}{l}\text { Barcelona Convention (1976, as } \\
\text { amended in 1995) and } \\
6 \text { Protocols }\end{array}$ & $\begin{array}{l}\text { Protection of the marine } \\
\text { environment and coastal } \\
\text { region of the Mediterranean }\end{array}$ \\
\hline Baltic Sea & $\begin{array}{l}\text { Helsinki Convention (1974, } \\
\text { amended version 1992) }\end{array}$ & $\begin{array}{l}\text { Protection and ecological } \\
\text { restoration of the Baltic Sea area }\end{array}$ \\
\hline Black Sea & Bucharest Convention (1992) & Protection from pollution \\
\hline $\begin{array}{l}\text { North East Atlantic } \\
\text { and Arctic Oceans }\end{array}$ & OSPAR Convention (1992) & $\begin{array}{l}\text { Protection of the marine } \\
\text { environment }\end{array}$ \\
\hline Caspian Sea & Framework Convention (2003) & $\begin{array}{l}\text { Protection of the marine } \\
\text { environment }\end{array}$ \\
\hline Caribbean & $\begin{array}{l}\text { Cartegena de Indias } \\
\text { Convention (1983) }\end{array}$ & $\begin{array}{l}\text { Protection and } \\
\text { development of marine } \\
\text { environment of the wider } \\
\text { Caribbean region }\end{array}$ \\
\hline South Pacific & Noumea Convention (1987) & $\begin{array}{l}\text { Protection of environment } \\
\text { from dumping }\end{array}$ \\
\hline South East Pacific & $\begin{array}{l}\text { Lima Convention (in force } \\
\text { 1986) }\end{array}$ & $\begin{array}{l}\text { Protection of the marine } \\
\text { environment and coastal areas }\end{array}$ \\
\hline South East Pacific & Quito Protocol (1983) & $\begin{array}{l}\text { Protection against pollution } \\
\text { from land based sources }\end{array}$ \\
\hline North East Pacific & Antigua Convention (2002) & $\begin{array}{l}\text { Protection and sustainable } \\
\text { development of the marine } \\
\text { and coastal environment }\end{array}$ \\
\hline
\end{tabular}




\begin{tabular}{|l|l|l|}
\hline \multicolumn{1}{|c|}{ Region } & \multicolumn{1}{|c|}{ Treaty } & \multicolumn{1}{c|}{ Subject matter } \\
\hline Red Sea & $\begin{array}{l}\text { Regional Convention for the } \\
\text { Conservation of the Red Sea } \\
\text { and Gulf of Aden Environment } \\
\text { Jeddah, 1982) }\end{array}$ & $\begin{array}{l}\text { Conservation of marine } \\
\text { environment }\end{array}$ \\
\hline East Africa & Nairobi Convention (1985) & $\begin{array}{l}\text { Protection, management } \\
\text { and development of the } \\
\text { marine and coastal } \\
\text { environment }\end{array}$ \\
\hline $\begin{array}{l}\text { West and Central } \\
\text { Africa }\end{array}$ & Abidjan Convention 1981 & $\begin{array}{l}\text { Protection and } \\
\text { development of marine and } \\
\text { coastal environment }\end{array}$ \\
\hline Antarctic & $\begin{array}{l}\text { Convention on the } \\
\text { Conservation of Antarctic } \\
\text { Marine Living Resources } \\
\text { (CCAMLR) (1982) }\end{array}$ & $\begin{array}{l}\text { Conservation of marine } \\
\text { living resources }\end{array}$ \\
\hline
\end{tabular}

\subsubsection{Other Supra-National Instruments}

Within the European Union, various directives (which are binding on member States) have played an important part in shaping ICM law at the national level and a variety of other non-binding instruments such as recommendations of the Council, are being used to promote the development of a common approach to ICM within the Union.

The Treaty Establishing the European Community ("the EC Treaty") prescribes the activities of the community, which must include establishing common policies in a number of spheres relevant to ICM, such as: environment, transport, agriculture and fisheries ${ }^{42}$. The EC Treaty was amended by the Treaty of Amsterdam ${ }^{43}$ which expanded the fundamental objectives of the community to include "a harmonious, balanced and sustainable development of economic activities" and "a high level of protection and improvement of the quality of the environment"44. The Treaty also requires environmental protection and requirements to be

42 EC Treaty articles 32-38 (agriculture), 70-80 (transport), 174-176 (environment).

43 The amendments entered into force on 1 May 1999.

44 Which is Article 2 EC. 
integrated into the definition and implementation of other community policies, particularly with a view to promoting sustainable development ${ }^{45}$.

Several EC Directives have had a significant impact on ICM in the Member States, despite the fact that no specific EC legislation dealing with ICM has been adopted. These include the Environmental Impact Assessment Directive 85/337/EEC 46 which requires the assessment of the potential environmental effects of a range of listed projects, before a decision is taken on whether or not to authorize them. (Many of the listed projects typically occur within coastal areas.)

The Water Framework Directive of $2000^{47}$, which replaced several previous directives on water quality, has also had a significant impact on approaches to ICM within the European Community. The Water Framework Directive requires Member States to identify river basin districts and to prepare river basin management plans to ensure that waters meet defined environmental objectives and quality standards by 2010. These requirements apply to surface fresh water, ground water, estuaries and coastal waters up to one nautical mile from the baseline of the territorial sea. Public participation is provided for in preparation of river basin management plans. The directive also aims to ensure that Member States impose full cost recovery charges for the use of water resources and the treatment of waste water by 2010 .

The Birds Directive, 79/409/EEC 48 deals with the conservation of all species of naturally occurring birds in the European territories of the Member States. The Directive requires Member States, among other matters, to designate "special protection areas" for the conservation of vulnerable species of birds. These protected area requirements are further enhanced by the provisions of the Habitats Directive 92/43/EEC ${ }^{49}$ which aims to promote the maintenance of biodiversity and to ensure the restoration or

45 Article 6 EC.

46 Official Journal, No. L175, 5 July 1985, p. 40.

47 Official Journl, No. L327, 22 December 2000, p. 1.

48 Official Journal No. L103, 25 April 1979, p. 1; amended by Official Journal No. L233, 30 August 1985; Official JournalNo. L115, 8 May 1991, p. 41; Official Journal No. L164, 30 June 1994, p. 9; Official Journal No. L223, 13 August 1997, p. 9.

49 Official Journal No. L206, 22 July 1992, p. 7; amended by Official Journal No. L305, 8 November 1997, p. 42. 
maintenance of natural habitats of community interest. The Habitats Directive provides for the designation of "special areas of conservation" in order to create a Pan-European Ecological Network called "Natura 2000". It requires Member States to take appropriate measures to avoid the deterioration of natural habitats in the special areas of conservation (which include the special protection areas established under the Birds Directive) and the assessment of plans or projects likely to have implications for the conservation objectives of such a site. It affords protection to a range of listed coastal habitats (among other habitats) and requires that plans or projects with significant negative implications for special areas of conservation may only be authorized for reasons of overriding public interest and the Member State must then take other measures to ensure that the overall coherence of Natura 2000 is maintained.

The European Union experience indicates how ICM has been advanced indirectly by regional legislation designed to produce a coherent approach among a number of nations to issue such as environmental impact assessment, the protection and improvement of water quality and the conservation of wildlife and habitats. From an ICM perspective, two trends within EC legislation appear to have been important factors in indirectly advancing ICM. The first concerns efforts to integrate the consideration of environmental concerns into planning and development processes of all sectors (reflected, for example, in the amendments to the EC Treaty and the EIA Directive). The second is the progressive movement towards management systems that are based on naturally defined areas such as watersheds and ecosystems (as reflected in the Water Framework Directive and the development of the Natura 2000 system of protected areas). Both reflect a move towards "systems thinking" which is fundamental to the ICM approach.

\subsection{Principles of International Law Relevant to National ICM Legislation}

\subsubsection{The Importance of International Law Principles}

The principles discussed below originate in international legal instruments, particularly those dealing with shared natural resources. In some cases these principles may have a direct effect on the content of national ICM legislation, for example where there are transboundary effects originating within a nation's coastal zone. Even when this is not so, the norms and 
principles of international law provide extremely useful guidance when drafting national ICM legislation. One of the reasons for this is that many principles of international law have been developed to deal with the preservation and conservation of natural resources that must be shared because they extend across the political boundaries between states ${ }^{50}$. The unifying factor in any coastal zone is water, which by its very nature is not constrained by administrative or political boundaries. This means that coastal ecosystems frequently span political boundaries (whether national boundaries or different jurisdictional boundaries within countries) which means that the political entities involved must find a means of sharing the use of resources provided by that ecosystem.

\subsubsection{Duty to Prevent, Reduce and Control Environmental Harm}

Customary international law now requires states to take adequate measures to prevent and control sources of serious transboundary environmental pollution or harm within their territories or under their control ${ }^{51}$.

The responsibility of states to ensure that activities within their jurisdiction or control do not cause damage to the environment of other states or to areas beyond national jurisdiction (such as the high seas) also appears in various international legal instruments ${ }^{52}$, particularly those dealing with the

50 Although the principle of equitable utilization of a resource shared by two or more countries is well established in international law, it should be noted that the Principles of Conduct in the Field of Environment for the Guidance of States in the Conservation and Harmonious Utilization of Natural Resources Shared by Two or More States (17 ILM (1978), 1091) which was adopted by the Governing Council of UNEP in 1978, remains controversial. As Birnie and Boyle (2002) point out, some of the opposition to the Principles arises from an absence of any definition as to what should be treated as a shared resource, while other states are concerned about limitations on their sovereign rights to exploit natural resources (see pp. 139-141).

51 Birnie and Boyle (2002) p. 109.

52 These include the Stockholm Declaration on the Human Environment (Principle 21), the Rio Declaration (Principle 2), and the Convention on Biological Diversity (Article 3). 
transboundary effects of activities carried out within a state ${ }^{53}$ and in relation to shared resources such as international watercourses ${ }^{54}$. The application of the principle is also evident in many other international treaties including UNCLOS 1982 (see articles 192 194).

The precise standard of conduct which a State must adhere to is expressed differently in different treaties. For example, State parties may be required to implement this principle by employing "best practical means at [the Parties'] disposal, and in accordance with their capabilities"55, or "best practicable means at their disposal"56 or "best environmental practice" and "best available technology"57. The common core of the obligation is "due diligence" in taking appropriate measures to prevent or minimize the risk of transboundary harm. In order to have acted with due diligence a State must act reasonably and in good faith and must regulate, or where necessary, prohibit, public and private activities over which it has jurisdiction or control in order to prevent them causing environmental harm. This does not prescribe a particular outcome or standard that must be achieved (e.g. a minimum threshold of harm that must not be exceeded) but instead requires

53 For example, the UNFCC (Preamble and Principle 2), the ILC $2000 \mathrm{draft}$ Convention on the Prevention of Transboundary Harm, and the 1991 Espoo Convention on Environmental Impact Assessment in a Transboundary Context. The Espoo Convention provides that: "The parties shall, either individually or jointly, take all appropriate and effective measures to prevent, reduce and control significant adverse transboundary environmental impact from proposed activities" (Article 2 (1)).

54 For example the Convention on the Protection and Use of Transboundary Watercourses and International Lakes, Helsinki, 17 March 1992 provides that adverse transboundary environmental impacts should prevented, controlled and reduced, without transferring the effects to other parts of the environment and if possible at source (Article 2(3) and(4)).

551981 Abidjan Convention for Co-operation in the Protection and Development of the Marine and Coastal Environment of the West and Central African Region, Article 4(1).

56 See UNCLOS, Article 194(1)

57 See, for example, the 1992 Paris Convention for the Protection of the Marine Environment of the North East Atlantic which requires the Parties to use best available technology and best environmental practices to prevent and reduce pollution from land-based and offshore sources (Article 2(3)(b) as read with Article 1(1) of Annex I and Article 1(1) of Annex III). 
a certain kind of conduct. It is a flexible approach that can be applied to a variety of situations.

\subsubsection{Sustainable Development and Use of Resources}

Agenda 21 adopted by the 1992 UNCED Conference in Rio de Janeiro identified as a key objective of marine and coastal area management and development: "the protection and sustainable development of the marine and coastal environment and its resources" 58 . The concept of sustainable development is not a legal principle in the strict sense. Its precise meaning is still contested, there is no agreement as to how to determine whether or not any particular development is sustainable, and it is perhaps better understood as a policy goal. Nevertheless, from the perspective of ICM law it is worthy of attention because it:

(a) is now almost universally endorsed by States and is mentioned in many international legal instruments and policy documents ${ }^{59}$;

(b) requires the application of other principles such as inter- and intragenerational equity (i.e. fairness both between the current generation and future generations and between the members of the current generation), and procedural principles such as those reflected in Articles 10, 16 and 17 of the Rio Declaration;

(c) has been recognized by the International Court of Justice as relevant to the interpretation of international law ${ }^{60}$ and has influenced the development of concepts such as sustainable utilization in relation to international watercourses and high seas fisheries ${ }^{61}$;

58 Agenda 21, Chapter 17, paragraph 17.1

59 For example the United Nations Conference convened in 2002 for the tenth anniversary of the Rio Conference, was entitled the World Summit on Sustainable Development. It has also been adopted as a national policy goal by many countries throughout the world (the USA, Australia, India, China, the Philippines), as well as by regional organizations (European Union, Southern African Development Community.

60 In the Case Concerning the Gabcíkovo-Nagymaros Dam.

61 See the 1997 UN Convention on the Non-Navigational Uses of International Watercourses and the 1995 UN Fish Stocks Agreement. 
(d) has the effect of making a State's management of its environment a matter of international concern ${ }^{62}$; and

(e) plays a central role in guiding policy formulation and decision-making at both the national and international levels.

The difficulties of deciding objectively whether or not a development is sustainable mean that it is unlikely that an international tribunal would apply sustainable development as a standard and decide that a State had failed to ensure that a particular development was sustainable. However, as Birnie and Boyle point out:

\begin{abstract}
"A more plausible argument is that although international law may not require development to be sustainable, it does require development decisions to be the outcome of a process which promotes sustainable development. Specifically, if states do not carry out EIAs, or encourage public participation, or integrate development and environmental considerations in their decision-making, or take account of the needs of intra- and intergenerational equity, they will have failed to implement the main elements employed by the Rio Declaration and other international instruments for the purpose of facilitating sustainable development" 63 .
\end{abstract}

In other words, it would appear that international law today requires States to take account of sustainable development as an objective and to establish procedures for moving towards achieving it.

One example of the application of the idea of sustainable development in national law is in the New Zealand Resource Management Act No 69 of 1991 which defines the purpose of a coastal management regime as the sustainable management of the coastal environment. Section 5 of the Act defines the sustainable management of the coastal environment as:

"managing the use, development, and protection of natural and physical resources (of the coastal environment) in a way, or at a rate, which enables people and communities to provide for their social, economic and cultural wellbeing and for their health and safety while -

(a) sustaining the potential of natural and physical resources (excluding minerals) to meet the reasonably foreseeable needs of future generations; and

62 See Birnie and Boyle (2002), p. 85. Also the Convention on Biological Diversity.

63 Birnie and Boyle (2002), p. 96. 
(b) safeguarding the life-supporting capacity of water, soil and ecosystems; and

(c) avoiding, remedying, or mitigating any adverse effects of activities on the environment."

\subsubsection{Principle of Preventive Action}

The essence of the preventive approach or principle is succinctly captured by Article 6 of the IUCN's Draft International Covenant on Environment and Development which states:

"Protection of the environment is better achieved by preventing environmental harm than by endeavouring to remedy or compensate for such harm"64.

This principle is based on the recognition that it is cheaper, safer and more ecologically desirable to prevent environmental harm occurring than to rectify it later (if indeed this is possible). As is the case with the duty to prevent, reduce and control environmental harm (discussed in section 3.5.2) this approach requires States to exercise "due diligence" rather than to attain a particular standard.

At the international law level the preventive principle has been articulated in many international instruments ${ }^{65}$. As an approach it is also implicit in provisions that establish international minimum standards to prevent pollution ${ }^{66}$; which require the use of "best available technology" or "best practicable means" to reduce pollution ${ }^{67}$; or which require the use of environmental impact assessments to identify potential threats in order that preventive measures may be taken ${ }^{68}$.

64 See IUCN Commission on Environmental Law, 2004, p. 3.

65 For example, Article 130(r)(2) of the EC Treaty and Article 35 of the Lomé IV Convention.

66 For example, MARPOL Annexes 1-5 and UNCLOS, 1982, Articles 210 and 211.

${ }^{67}$ For example, UNCLOS (1982) Article 194(1), North East Atlantic Convention (1992) Article 2(3)(a)(i) and the Danube Convention (1994), Annex 1.

68 For example, Espoo Convention, 1991, Article 2(1). 
Similarly at the national level, in some cases this principle is expressed as such but is more commonly expressed indirectly. Its application in the context of environmental or ICM legislation can be seen in the imposition of a duty to avoid causing environmental harm, and in requirements for environmental impact assessments, development permits and consents.

\subsubsection{Precautionary Principle}

While the preventive approach is aimed at promoting conduct which avoids harm that is foreseeable or likely ${ }^{69}$, the precautionary principle or approach ${ }^{70}$ is aimed at ensuring that the taking of preventive measures is not postponed because there is scientific uncertainty about how likely the harm is to occur or how bad it will be. Read together these approaches or principles emphasize the need to be proactive in avoiding environmental harm and to be cautious in authorizing activities that have the potential to damage the environment, particularly where our understanding of the risks is limited.

The classic formulation of the precautionary principle is contained in Principle 15 of the Rio Declaration, which states that:

"In order to protect the environment, the precautionary approach shall be widely applied by states according to their capabilities. Where there are threats of serious or irreversible damage, lack of full scientific certainty shall not be used as a reason for postponing cost-effective measures to prevent environmental degradation."

69 For example the customary international law obligation to prevent transboundary harm is only triggered after "convincing evidence" that such harm will occur (see the Trail Smelter arbitration).

70 Some States, notably the USA, have resisted the use of the term "precautionary principle" instead of "precautionary approach" in international instruments such as the 1995 Fish Stocks Convention, arguing that approach is more flexible and potentially less restrictive than principle. However, as Birnie and Boyle point out, few commentators regard the difference in terminology as significant. (p. 116, especially footnote 266). 
It is expressed in Article 7 of the IUCN's Draft International Covenant on Environment and Development as follows:

"Precaution requires taking appropriate action to anticipate, prevent and monitor the risks of potentially serious or irreversible damage from human activities, even without scientific certainty"71.

This concept has been developed largely in response to the recognition that our knowledge of the long term effects of human activity on the natural environment is woefully inadequate and that by the time we have scientific proof of harmful effects, they may already have occurred. It requires more than merely repair of damage or the prevention of risk, it requires the reduction and prevention of adverse environmental impacts even before the threshold of risk is reached ${ }^{72}$. It implies that action must be taken even if the risks are not yet certain but only probable or even possible. In other words, it lowers the standard of proof required before preventive action must be taken. The scientific evidence need not establish that the environmental harm will or is likely to occur, but only that there is "reason to believe"73 that it will or that there are "reasonable grounds for concern"74.

\title{
As Freestone explains:
}

\begin{abstract}
"The precautionary approach then is innovative in that it changes the role of scientific data. It requires that once environmental damage is threatened action should be taken to control or abate possible environmental interference even though there may still be scientific uncertainty as to the effects of the activities"15.
\end{abstract}

The application of this principle at an international level is exemplified by the 1985 Vienna Convention for the Protection of the Ozone Layer ${ }^{76}$ and the 1987 Montreal Protocol on Substances that deplete the Ozone Layer ${ }^{77}$. The Vienna Convention and its protocol committed the parties to reduce

71 See IUCN Commission on Environmental Law, 2004, p. 3.

72 See Gúndling, 1990.

73 See the 1996 Protocol to the London Dumping Convention, Article 3(1).

74 For example, the 1992 Paris Convention for the Protection of the Marine Environment of the North East Atlantic, Article 2.

75 Freestone, 6 JEL (1994) at 211 quoted by Birnie and Boyle, 2002, p. 117.

76 ILM 26, 1987, 1516.

77 ILM 26, 1987, 1541 
emissions of certain substances at a time when it had not been conclusively established that they were causing ozone depletion in the upper atmosphere.

The precautionary principle or approach has been incorporated into treaties dealing with marine pollution, international waterways, air pollution and climate change, transboundary trade in hazardous waste and endangered species, and the conservation of biological diversity and marine living resources ${ }^{78}$. Birnie and Boyle argue that the core concept that scientific uncertainty cannot be used to justify a failure by a State to perform its obligations to protect the environment and to use natural resources sustainably, is now a principle of international law that can be relied on by courts. However they point out that State practice is not consistent as regards the precautionary measures that must be applied in any particular circumstances and accordingly international law at this stage does not impose a duty on States to meet any particular standard in relation to the measures to be taken. For this reason some international treaties and non-binding texts specify what the implications of the precautionary approach are in respect of particular circumstances.

In relation to fisheries, for example, the UN Fish Stocks Agreement requires coastal States and States fishing on the high seas to apply the precautionary approach in relation to straddling and highly migratory fish stocks (Article 5(c)). States are required to establish precautionary reference points for such stocks, to develop data collection and research programmes, to improve decision-making and to take various kinds of uncertainty into account. For new fisheries, "States shall adopt as soon as possible cautious conservation and management measures"79.

Similarly the FAO Code of Conduct urges States and sub-regional and regional fisheries management organizations to apply a precautionary approach to the conservation, management and exploitation of living aquatic resources (Article 6.5) and then, in language quite similar to the UN Fish Stocks Agreement, specifies what this will involve (Article 7.5). Further guidance is then provided in technical guidelines to the precautionary approach, which sets out its application to fisheries management, fisheries research, fisheries technology and species introduction.

78 See the discussion in Birnie and Boyle, 2002, p. $117 \mathrm{ff}$.

79 UN Fish Stocks Agreement, Article 6 and Annex II. 
The precautionary principle has been incorporated into the environmental law regimes of the European Union ${ }^{80}$, and many other countries including Algeria $^{81}$, Australia ${ }^{82}$, France ${ }^{83}$, Macedonia ${ }^{84}$ and Portugal ${ }^{85}$.

The precautionary principle is particularly appropriate in the context of ICM because of the vulnerability of many coastal resources (and hence the likelihood of irreparable harm occurring swiftly) and because scientific knowledge about the complex web of interconnected biological processes found in coastal ecosystems is far from complete.

\subsubsection{Polluter Pays Principle}

This principle is concerned with the re-allocation of the social costs of environmental degradation from society at large to those responsible. The IUCN's Draft International Covenant on Environment and Development formulates this principle as follows:

"States shall apply the principle that the costs of preventing, controlling and reducing potential or actual harm to the environment are to be borne by the originator" 86 .

80 The Maastricht Treaty (which amended the EC Treaty with effect from 1 November 1993) introduced into the EC Treaty a new Article 130(r)(2) which states: "Community policy on the environment ... shall be based on the precautionary principle and on the principle that preventive action should be taken, that environmental damage should as a priority be rectified at source and that the polluter should pay. ... "The EC's policy on the application of the precautionary principle is set out in Communication on the Precautionary Principle, COM (2000)1. See also the Recommendation of the European Parliament and of the Council of 30 May 2002 concerning the implementation of integrated coastal zone management in Europe (Box 4).

81 Loi no 3-10 relative à la protection de l'environment dans le cadre du développement durable, article 3 .

82 Environment Protection Act 1970, section 1 (added by Act No. 7 of 2001).

83 Loi constitutionnelle $n^{\circ}$ 2005-205 relative à la Charte de l'environment.

84 Law on Waste Management, 2004, section 9.

85 Lei de Aqua, No. 58/2005, section 3(1)(e).

86 IUCN Commission on Environmental Law, 2004, Article 11(4). The draft Covenant uses the term "originator" rather than "polluter" in order to indicate that it encompasses potential as well as actual harm. 
Versions of this principle are to be found in many international instruments ${ }^{87}$ and it is one of the cornerstones of the environmental policy of the European Community 88 . It has also been incorporated into the laws of many countries. For example, provisions which empower the authorities to recover the cost incurred in remedying environmental harm from the person who caused it, are giving effect to the polluter pays principle.

It is a useful tool in the coastal context since it should result in improved allocation of the scarce resources by imposing the full cost of any use of a resource (including the cost of any incidental damage to the environment) on the user.

\subsubsection{Equitable and Sustainable Use}

The customary international law principle of equitable utilization was developed primarily in relation to international watercourses ${ }^{89}$. It emphasizes that the community of interests of co-users of a shared water resource gives rise to an obligation to negotiate in good faith to bring about an equitable allocation of the resource (which would include allocating the use of the environment to assimilate pollution).

The principle of equitable use is included in the 1992 Helsinki Convention on Transboundary Watercourses and International Lakes ${ }^{90}$. It has also been applied to other shared resources such as fish stocks ${ }^{11}$. What constitutes "equitable use" depends on a consideration of all relevant factors and a

87 For example, Principle 16 of the Rio Declaration (1992).

88 It is expressly referred to in article 130(2) of the EC Treaty having been introduced by as an amendment made by the Maastricht Treaty.

89 See for example the River Oder Case (1929) P.C.I.J. series A, No. 23, and the Lake Lanoux Arbitration (1957) I.L.R. 101.

90 Article 2(2) of the Convention on the Protection and Use of Transboundary Watercourses and International Lakes concluded at Helsinki on 17 March 1992, provides that: "The Parties shall in particular, take all appropriate measures: ...

(b) To ensure that transboundary waters are used with the aim of ecologically sound and rational water management, conservation of water resources and environmental protection;

(c) To ensure that transboundary waters are used in a reasonable and equitable way ...".

91 Fisheries Jurisdiction Case (United Kingdom $v$ Iceland) [1974] I.C.J. Rep. 3. 
balancing of the different interests of users of the resource. It is noteworthy that the Helsinki Convention specifically develops the concept by requiring "reasonable use" and "ecologically sound and rational water management". (Factors which should, in any event be taken into consideration in determining what would constitute an equitable apportionment in the circumstances of a particular case.)

As mentioned above, the idea of sustainable development has influenced the development of the general principle of equitable utilization to a principle of sustainable utilization, at least in relation to international watercourses and high seas fisheries ${ }^{92}$.

The fact that this equitable principle is not expressly mentioned in ICM legislation does not necessarily mean that it is not applied. For example, the CZMA of the USA requires "wise use of the land and water resources of the coastal zone"93 and that "local land use and water use regulations within the coastal zone do not unreasonably restrict or exclude land uses and water uses of regional benefit"94. Interpreting these provisions will inevitably involve a balancing of the legitimate interests of users of a common resource. This principle can provide a useful general guide for decision-makers in such situations.

\subsubsection{Public Participation}

Principle 10 of the Rio Declaration supports the notion that citizens should be allowed to participate in making decisions that affect the environment, should be give access to relevant information and effective access to justice. These rights to participate are also reflected in many other international instruments concerned with the protection of the environment ${ }^{95}$. The

92 See the 1997 UN Convention on the Non-Navigational Uses of International Watercourses and the 1995 UN Fish Stocks Agreement.

93 CZMA, section 303(2), which establishes as national policy that states should be encouraged to implement management policies to achieve this purpose among others.

94 CZMA, section 306(d)12, which establishes as a prerequiste for Federal approval and funding that all state management programmes contain a method to do this.

95 For example: the World Charter for Nature (Principle 23); the 1991 Convention on EIA in a transboundary context; and the 1992 CBD. 
importance of public participation in ICM, is referred to specifically in Agenda 21. Article 17.6 provides that local and national mechanisms established to ensure integrated management and sustainable development of coastal and marine areas and their resources: "should include consultation, as appropriate, with the academic and private sectors, non-governmental organizations, local communities, resource user groups, and indigenous people."

As public concern about environmental matters has increased there has been a corresponding world-wide trend to legislate to provide increased public participation in relation to environmental decision-making. Public participation in coastal decision-making, and access to information and effective legal remedies, is particularly important for ICM for a number of reasons. Involving the users of the coast improves the quality of decisions, increases the likelihood of voluntary compliance with management measures and reduces the potential for conflicts among users. Furthermore, in countries where some or all of the coastal area is defined as public property, the public is the notional owner of the coastal area and should have a right to participate in decisions that affect it (particularly where there is a risk of the coast being degraded).

In the USA a state coastal zone management plan will not receive Federal approval and funding unless the state has held public hearings in the development of the programme ${ }^{96}$ and it is national policy to encourage the participation of the public in carrying out the purposes of the CZMA ${ }^{97}$.

\subsubsection{Taking Account of International Law Principles}

As discussed above, there are a growing number of principles of international environmental law that must be taken into account when drafting national ICM legislation. For example, both the duty to prevent transboundary environmental harm and the duty to take preventive action require a State to exercise due diligence which will include establishing an effective legal and institutional framework. It is therefore essential that those framing ICM legislation are familiar with the applicable principles of international law.

96 CZMA, section 306(4).

97 CZMA, section 303(4). 
In many cases drafters of national ICM legislation will have to consider the possibility that activities within the area regulated by the legislation may have a negative impact on the environment in other States. This is usually the case because the fundamental feature of the coastal area is the interface between water and land and every aspect of ICM relates to water in some way ${ }^{98}$. Water is clearly not constrained by political or administrative boundaries and so freshwater and marine aquatic ecosystems are often shared by more than one country, and pollution originating in one jurisdiction may well affect the environment of other States. In these situations it is essential to identify the responsibilities of the country in question to other States, and to ensure that appropriate legal mechanisms are put in place internally to enable the State to fulfil its obligations under international law.

98 Water has been described as "the major integrating force in coastal resource systems", Clark, 1992, pp. 49 and 50. 
PART II

DEVELOPING A LEGAL FRAMEWORK FOR

ICM 


\section{THE PROCESS}

\subsection{The Importance of Process}

When developing or strengthening legal frameworks for ICM it is most important to bear in mind that:

1. ICM itself is an on-going process (see the definitions in Box 1);

2. the nature of the process that is adopted will have a profound effect on the outcomes, including an important impact on the level of political support for new legislation, the content of the legislation, how effectively it is implemented, and on compliance;

3. the legal framework is itself part of a wider governance structure which includes institutions, policies, economic forces, value systems, religious and cultural norms and other factors that govern human behaviour in relation to the coastal environment; and

4. the process of developing an appropriate legal framework for ICM is an integral part of the on-going process of introducing and implementing ICM as a whole.

The nature of the process used to develop an ICM programme and laws to support it should reflect the key principles and approaches inherent in ICM. In particular it is important that every effort is made to facilitate the effective participation of stakeholders. This is important not only because of the valuable insights and information which they will introduce to the process, but also to build an understanding of why ICM-related legislation is necessary and desirable. This is essential to building the political consensus necessary to ensure that appropriate legislation is enacted (despite the fact that it might be opposed by certain interest groups) and for the public to perceive the legislation as just. Public awareness of the existence of legislation, and perceptions as to its legitimacy, can have a profound effect on levels of compliance (see Box 19). In essence, people are far more likely to comply with a law that they know about, understand, and perceive as necessary and just. Giving people an opportunity to participate in the process that shapes that law and to debate its content, is one of the best ways of achieving this. 
It is also important to involve state agencies in the formulation of policies and laws that affect them, or which they are required to implement. If public sector stakeholders have not been adequately involved, it tends to be very much more difficult to secure their co-operation and proactive involvement in implementing those laws.

One of the key factors in the widely acknowledged success of the Coastal Zone Management Program (CZMP) in the United States over the past thirty years has been its emphasis on process rather than on prescribing exactly what states must do ${ }^{99}$. The Federal Coastal Zone Management Act of $1972^{100}$ (US CZMA) established a collaborative Federal-State Coastal Zone Management Program to achieve the overall national goal "to preserve, protect, develop and, where possible, to restore or enhance the resources of the Nation's coastal zone". Participation by States in the CZMP was voluntary but as a result of powerful incentives (discussed in 6.3.1) all 35 eligible coastal states and territories and states bordering the Great Lakes have participated in the CZMP.

One of the interesting features from a process point of view is that the Federal Government gave participating states a great deal of freedom to determine the content of state Coastal Management Programs and how to implement them. The Federal Government would share the costs of developing and implementing state Coastal Management Programs provided that they conformed to national policies and included certain basic minimum requirements (e.g. an identification of boundaries and the organizational structure to implement the Coastal Management Program).

The US CZMA also requires states to control the use of land and water in coastal areas by one or more of the following methods:

1. local government implementation in accordance with standards established, reviewed and enforced by the state;

2. direct planning and regulation by the state of land and water use;

99 The US CZMP is discussed in more detail in section6.3.1.

100 The US CZMA has been amended or re-authorized at least 10 times since it was first enacted. 
3. state administrative review of all development plans, projects, and land and water use regulations, prepared by state agencies, local authorities or private developers, to ensure that they are consistent with the State coastal management programme, with powers to approve or refuse to authorize them after public hearings ${ }^{101}$.

The emphasis on process and the absence of detailed prescriptions concerning the content of the state Coastal Management Programs was a deliberate attempt to encourage an "adaptive, experimental approach to State Program design"102. This has yielded a wide range of responses ranging from the establishment of super-agencies with wide-ranging planning and regulatory powers (e.g. California), through systems based on local coastal plans (e.g. Alaska and North Carolina), to networks designed to improve coordination among existing institutions (e.g. Hawaii). The voluntary nature of the CZMP, the provision of Federal incentives, and the freedom given to states to determine the best means of achieving the common national purpose given the specific circumstance in that state, have all been important in creating a functioning, comprehensive and flexible system based on a partnership between the Federal government and state governments.

\subsection{Design the Process}

The first step in introducing ICM at the national or sub-national level for the first time is to design the process for doing so ${ }^{103}$.

Since the legal reform process should be a sub-component of a much wider ICM initiative, it is important that the process used to initiate ICM as a whole should reflect the key procedural characteristics necessary to produce an effective legal framework for ICM. These include: effective participation by stakeholders in determining the content of ICM policies and laws and the

\section{USC $\$ 1455(11)$}

102 Kem Lowry, quoted by Humphrey, Burbridge and Blatch, 2000.

103 Although this section focuses on designing the process for introducing ICM for the first time, it is important to note that well-functioning ICM programmes should include mechanisms for periodically reviewing the adequacy of existing laws and coastal governance mechanisms in order to find ways of improving and developing them. 
manner in which they are formulated; political support, public legitimacy and a degree of public "ownership" of the process.

The South African experience in formulating what has been described as "the world's first consensus based national policy for the sustainable development of the nation's coastal regions and natural resources"104 is instructive in this regard because of the degree of attention given to process and to public participation in particular (see Annex 3). The transition that took place in South Africa between 1990 and 1994 from minority rule under the apartheid system to a new democratic order, created an opportunity to address the limitations of coastal governance at that time in a new way. An innovative and highly participatory process to develop a new coastal policy was developed which resulted in the adoption in 2000 of a national policy on sustainable coastal development ${ }^{105}$.

Four key stages in the process were identified:

1. identifying coastal issues and defining a vision for the coast;

2. generating policy options that identified a desired policy objective, the actors that would be involved in achieving it and the practical actions that would be required to address the issue of concern;

3. assessment of the implication of the different policy options; and

4. selection of preferred policy options based on a consideration of the implications.

During phase 1 a specialist study on institutional and legal matters was commissioned in order "to understand better local, provincial and national institutions, as well as the legislative, regulatory and other factors likely to affect policy formulation and implementation"106. During phase 2 a further study was commissioned to examine the different institutional options for implementing the policy. However a determination of the preferred legal means of implementation was deferred until after the policy had been completed.

104 Professor Peter Burbridge, quoted by Glavovic, 2000, p. 67.

105 White Paper for Sustainable Coastal Development in South Africa, Department of Environmental Affairs and Tourism, April 2000.

106 Glavovic, 2000, p. 12. 
Once the policy had been adopted by central government, a specialist legal report was commissioned to determine the best legal means of implementing the policy. That report analyzed the legal mechanism available for implementing each of the 62 objectives of the policy, and made recommendations regarding the legal and institutional changes that would be required to provide appropriate mechanisms to attain each objective. It also assessed the relative merits of several alternative approaches to legislative reform that had been identified during the policy formulation process ${ }^{107}$. The government then made a decision on the basis of that report to enact a new framework Act dealing with coastal management.

Unfortunately, at that point public participation was excluded and, ironically, the legislative process bogged down. The lack of public participation has been justified on the grounds of efficiency and on the basis that it was simply implementing policy objectives arrived at through exhaustive public consultation. However, by severely restricting public participation at a late stage in the process much of the momentum and public support built up earlier in the process has been undermined. Furthermore, in the absence of countervailing views from other stakeholders the political concerns of key government officials have had a decisive influence on the draft legislation. At present, the draft Bill has still not been released for public comment, despite frequent announcements of its imminent publication. It remains to be seen whether or not the stakeholders that were actively involved in the policy formulation process in the 1990s will comment on the draft and the extent to which the Bill will be redrafted to take account of these comments.

\subsection{Define Overall Purpose, Policy Objectives and Legal Objectives}

It is essential to clearly define the purpose, goals and objectives of ICM in the country or region concerned before attempting to evaluate existing

107 The approaches that were considered included: (i) amending the National Environmental Management Act by adding a new chapter dealing specifically with coastal issues; (ii) making relatively minor amendments to a range of existing legislation to ensure that coastal issues were specifically considered; (iii) substantially revising either the Sea Shore Act or the Marine Living Resources Act to introduce ICM; or (iv) enacting a new framework coastal management Act. 
legislation relevant to coastal governance or to develop new ICM legislation. Poor policy formulation inevitably leads to poor law.

Most of the policy objectives from the legal reform process will be derived from, and in some cases identical to, the objectives of the ICM programme as a whole (e.g. to secure public access to the seashore). However a legal reform process will usually have other objectives that relate specifically to legal reform. For example, it may be appropriate to set objectives such as:

- to draft legislation that is clear and easily understood by those who will use it most;

- to facilitate effective public participation in the development of the legislation;

- to design decision-making processes that are transparent, that involve all relevant parties, and that decide on a holistic rather than sectoral evaluation of the facts;

- to establish procedures that reduce the potential for conflict among government agencies, among users of the coast, and between users and government agencies (see section 5.5);

- to establish conflict resolution mechanisms;

- to reduce bureaucracy and make it easier for the public to comply with the law;

- to reduce the State's costs in implementing and enforcing coastal laws.

\subsubsection{Increasing Legal Certainty and the Quality and Transparency of Decision-Making Processes.}

Good legislation should be "certain" in the sense that those to whom it applies should able to understand it easily and to ascertain what is required so that they can modify their behaviour accordingly and avoid being penalized for actions which they believe to be lawful at the time. If the legal framework is known and understood by everyone and is implemented and enforced in a consistent manner, it will not only increase compliance, it will also reduce the risk to economic and social entrepreneurs.

For example, developers who incur costs in developing projects run a risk that the expenditure will be wasted if they do not receive the necessary authorization to proceed. The risk of this occurring will be reduced 
significantly if the developer is able to ascertain in advance which coastal areas are regarded as ecologically sensitive, the exact procedure to be followed to obtain the necessary authorizations, and the criteria that will be applied in deciding whether or not to grant them.

In most cases, the more transparent the regulatory framework, the more certain it is. "Transparency" in this sense refers to the degree to which the workings of the regulatory system are clear and "visible" to those affected by it. Increasing the transparency of a regulatory system usually reduces the opportunities for corruption and increases the predictability of administrative decision-making by making officials more accountable to the public. For example, a licensing procedure that states that a license must be granted if certain clear criteria are met, requires reasons to be given for any refusal of the license, and provides for a right of appeal. It is more likely to produce decisions that are consistent with the purposes of the law than a procedure that simply gives officials a wide discretion as to whether or not to grant a license.

\subsubsection{Reducing the Cost to the State of Implementing and Enforcing Coastal Laws}

In many countries, laws are enacted without giving adequate consideration to how they will be enforced and in particular to the human resources and other costs that will be incurred (or saved) in effecting the regulatory reforms. The successful introduction of ICM should result in very substantial economic benefits which should outweigh the regulatory costs of implementing the new regime (see the experience of the European Union). However, changes in laws may create additional costs for particular government departments or coastal users, or shift costs from one to another (e.g. from national to provincial government) while the long term economic benefits of the changes may accrue to other parties. Inadequate consideration of these aspects prior to implementation can give rise to considerable resistance when implementation is attempted. In many cases, it is helpful to make at least a rough estimate of the regulatory costs. This can be done, for example, by estimating the proportion of the total budget of an agency that is currently devoted to the implementation and enforcement of a particular group of laws and then comparing it with the anticipated costs of implementing and enforcing the proposed regime. 


\subsubsection{Improving Communication About the Law}

Most people do not read legislation. Consequently they modify their behaviour in response to a version of the law that has been communicated to them in various ways (e.g. by government officials, through the press or in conversations with other people in a similar position), and not in response to the legislation itself. Obviously a person who does not know of the existence or content of the law cannot modify his or her behaviour accordingly, and so any legal reform will be completely ineffectual in relation to such a person. This means that it is essential to communicate the nature of any proposed legal reform and its implications for those affected as widely and clearly as possible. It is also important to communicate why the changes are necessary or desirable and to allow stakeholders to have a role in commenting on and where appropriate, shaping the new legislation. Voluntary compliance with rules increases if those affected know about them, understand them, and perceive them to be just and necessary (see section 11.2).

\subsubsection{Involving Stakeholders}

It is crucial to involve stakeholders in the legal reform process and not only in the process of developing ICM programmes. As discussed in section 3.5.8, the involvement of stakeholders in environmental decision-making is recommended by a number of international instruments. More importantly, it is fundamental to the inclusive, holistic and systemic approach that is inherent in ICM. Experiences in many countries also confirm the importance of taking great care to ensure the early and effective involvement of all parties with an interest in the coast. This may include individuals, public bodies at the national, regional and local levels, businesses, nongovernmental organization, indigenous and local communities, and representatives of user groups such as fishers, tourism operators, and property owners. It may even involve interacting with other countries and with supra-national, regional or global organizations.

A full discussion of how to ensure effective public participation in ICM initiatives is beyond the scope of this publication, but from a legal perspective it is important to bear the following in mind:

- the key findings and implications of any detailed analysis of an existing legal framework should be distilled into a short, non-technical form, and where appropriate, explained at public meetings to enable people to participate in a meaningful way in discussions on the legal aspects of ICM; 
- during the public consultation process it is important to convey that law need not only be used as a coercive instrument, but can be used to create an environment which makes it easier to undertake activities that are consistent with approved coastal policies and programmes;

- people who live near the coast and depend directly on it for their livelihoods often have very important perspectives on what problems need to be addressed and how this should be done. Legal specialists can play an important role in identifying different legal mechanisms and approaches that could be used to address the issues identified. However it is important to ensure that these are expressed and communicated in a manner that allows for a meaningful dialogue between stakeholders and lawyers;

- changing laws or introducing new legislation almost invariably involves changes in institutional structures, social relations, and the rights and obligations of citizens. This usually results in the perception that some groups will gain and others lose as a result of the changes. For this reason it is essential to build a strong social and political consensus around the need and desirability for change (i.e. to introduce ICM). It is advisable to do this at an early stage in the process in order to overcome the resistance from special interest groups that will almost inevitably surface during the process of consulting on and enacting coastal legislation;

- The process of public participation must extend beyond the policy formulation phase and stakeholders must be given adequate opportunity to read, understand, discuss and comment on draft legislation and public authorities must give careful consideration to the comments received. A failure to do so may undermine the legitimacy of the whole process.

\subsection{Analyse and Evaluate Existing Governance Framework}

Any legal reform initiative aimed at establishing or improving the legal environment for ICM must be based on a thorough understanding of the existing laws and governance practices that influence human activities within the coastal area. It is also important to evaluate the governance system as a whole by looking at its effectiveness in the past and by considering how effective it is likely to be in facilitating the attainment of the goals and objectives of the ICM programme over, say, the next 20 years. This means that this phase of the process should involve not only an analysis of the text of the relevant legislation, but also an assessment of how the legislation is 
actually implemented and enforced by various institutions. It is not unusual to find that the reality is very different from what one might expect from reading the legislation.

One or more specialist studies should be commissioned at an early stage in the reform process so that all participants in the ICM programme have access to information regarding the existing laws, their perceived deficiencies, and the options for addressing them. It is important to integrate the lawyers involved in such assessments into the wider process of identifying and evaluating policy options to ensure that there is a dialogue between them and other stakeholders and specialists. The lawyers need to hear from those affected by existing legislation about how they experience the existing laws, and what works and what doesn't. On the other hand the lawyers should explain to the stakeholders and other specialist the various legal approaches or mechanisms that can be introduced to deal with specific issues of concern and obtain their feedback on which options the stakeholders consider to be most desirable.

The following observations may be useful in relation to this phase of the reform process.

\section{Define the scope of the study broadly, but focus most attention on matters that are most fundamental to ICM.}

Since ICM is concerned with the management of an area rather than a specific sector or activity, to obtain a full picture of the applicable legal framework it is necessary to review a wide range of laws and institutional practices that affect human activities in coastal areas. These are also often at different levels within government (e.g. local, provincial or national). This may require reviewing laws that:

- define the rights and duties of owners and users of coastal resources (e.g. the constitution and laws regulating the ownership or use of land, water and the seashore);

- govern the management and exploitation of natural resources (e.g. legislation relating to fisheries, forestry, minerals, and water);

- promote the conservation and protection of the environment and wildlife; 
- provide a structure within which human and other resources can be organized and co-ordinated for the purpose of attaining long-term strategic objectives (e.g. legislation dealing with national, regional or local planning or the establishment of financing mechanisms); and

- establish mechanisms for averting or resolving disputes concerning the use of coastal resources (e.g. legislation that provides for the use of techniques such as conciliation and arbitration).

Rather than analysing each of these laws separately, it is often useful to group the analysis according to the main themes of the ICM programme. For example a thematic analysis would discuss all legal provisions relevant to a theme such as public access to the coast, together even if they were to be found in many different statutes.

\section{Clarify at the outset what criteria will be used to evaluate the laws.}

In the first instance a law should be measured against the yardstick of the policy goals that it was designed to achieve. For example, has the fisheries law been effective in achieving the policy goal of reducing or eliminating excessive and unauthorized fishing? However governance approaches and policy goals change over time (e.g. from a sectoral to integrated approach to coastal management) so a law that was once considered effective in that it achieved the result it was intended to, may be regarded as inappropriate when measured against new policy goals. In the context of a legal reform process the current legislation should be evaluated in relation to the new policy objectives rather than those that applied when the legislation was first drafted. If the criteria are not well defined the evaluation process is likely to be difficult and the outcomes inconclusive.

Consider the extent to which the governance system as a whole (including the laws, institutional framework and approach to implementation) reflects the fundamental principles of ICM.

When one is focussed on specific issues (e.g. evaluating the extent to which the legal framework is appropriate to achieve a specific objective such as controlling building along the coast), it is easy to lose sight of higher level goals such as the establishment of a governance system that is integrated and comprehensive. It is important for any assessment to comment not only on the specifics but also to evaluate the extent to which the existing or proposed 
legal framework, viewed as a whole, is consistent with ICM which is based on a holistic approach. (See Box 7.)

Box 7

HOW INTEGRATED IS THE LEGAL FRAMEWORK ITSELF?

The following questions can be used as a yardstick for assessing the extent to which an existing or proposed legal framework for coastal management reflects the holistic and integrated approach that is fundamental to ICM.

1. Is the scope of the legislation broad enough to encompass:

(a) the geographical area necessary to be able to achieve the objectives of the ICM programme (geographical jurisdiction);

(b) the institutions and private persons which have the powers to control coastal resources (jurisdiction over legal persons); and

(c) the subject matter necessary to achieve the objectives of the ICM programme (e.g. environmental quality and protection, economic development, and the conservation of marine and terrestrial living resources)?

2. Do the substantive law rights and duties created accord with the overall policy objectives of the ICM programme? (For example a right of unrestricted public access to the coast or to mine minerals in coastal areas may conflict with a policy objective to protect fragile coastal ecosystems.)

3. Do existing legal and administrative procedures ensure that all material information will be considered and that holistic as opposed to sectoral criteria will be used in coastal planning and decision-making? (For example, will the potential impact of developments on the coastal environment be taken into account when conducting and assessing EIAs and in making decisions regarding resource use permits?)

4. Are there procedural mechanisms for ensuring that at any one time the legal rules and criteria applied by different institutions and at different levels in the public sector hierarchy (e.g. national, provincial and local government) and across different sectors will be consistent with the objectives of the ICM programme? 
Identify the key issues of concern and ensure that the evaluation makes it clear bow these are being, or will be, addressed.

Implementing ICM is different in different countries but there are nevertheless a number of issues that are relevant to structuring legal frameworks for ICM in almost all countries. These include:

- establishing a system for planning coastal areas that allows for the proactive planning of coastal development and informs decisions concerning the allocation of rights to use coastal resources;

- ensuring that the legal rights and duties of property owners and other coastal users (including customary law rights) support rather than prevent or unreasonably impede, the achievement of coastal policy objectives;

- establishing effective institutions, co-ordinating mechanisms, and other means of ensuring effective implementation of ICM; and

- improving levels of compliance with coastal legislation.

An indication of the type of questions that are useful to pose in this regard are set out in Box 8 .

\section{Box 8}

\section{ISSUES IN EVALUATING LEGAL FRAMEWORKS FOR ICM}

(The following list of questions is indicative only and is not a complete checklist.)

The planning process

Is there a body that has a legal mandate to prepare development or management plans for the coastal area - even if these are not specifically conceived for ICM purposes?

Does the planning body have adequate powers to prepare the plans?

Are the coastal areas and scope of the plans defined?

Is there a legally prescribed process that must be followed to prepare, approve, review and amend the management plans and does it provide for effective public participation?

What is the legal status of the plans and policies? For example, is the plan binding on other agencies or does it merely provide guidance for decision-makers? 
Does the planning process take into consideration regional and international commitments?

Are there mechanisms for encouraging and enforcing compliance with the plans?

How can existing customary law rights be incorporated into, or recognized by, the new regime?

Are further limitations on the existing right of private owners necessary, and justifiable, in order to attain ICM policy goals, and will it be necessary and possible to pay compensation for affecting these rights?

\section{Implementation}

Are there clearly identified bodies mandated to implement the plans and do they have the necessary legal powers to do so?

Are there processes for consultation and coordination between relevant agencies and for resolving interagency conflicts?

Does the legal system as a whole provide suitable legal mechanisms to implement the plan?

Do other laws conflict with or hinder the attainment of ICM objectives? For example, inadequate controls on deforestation or harmful agricultural practices in the catchment area may result in increased sedimentation in rivers with negative consequences for coastal areas.

\section{Existing rights and obligations}

Are the rights of existing owners and users of the coastal areas - including the rights of groups who have traditionally used coastal resources - clearly defined and legally enforceable?

Is the existing distribution of public and private rights to own and use coastal land and resources conducive to protecting environmental quality and long-term sustainable development, including ensuring equitable access and use by the current generation and intergenerational equity?

How will implementation of the plan affect existing rights?

Are there adequate mechanisms to encourage and enforce compliance? For example do the relevant authorities have the necessary powers an capacity, including powers of enforcement in exclusive economic zones in connection with international activities and, where appropriate, are there incentives for selfregulation by local stakeholders?

Is the legislation that is proposed to facilitate ICM consistent with the legal system as a whole, consistent with international commitments, clear, equitable and enforceable, bearing in mind financial, institutional and other constraints?

(Adapted from FAO 1998) 


\section{Draw on experiences in other countries.}

Many lawyers and policy-makers resist spending time considering the approaches adopted by different countries, reasoning that because the conditions in other countries are different, the approaches that they adopt are likely to be inappropriate. It is certainly true that laws need to be tailored to the specific circumstance of each country and that how a law functions is determined to a great extent by the social, political, and legal context within which it exists. However, despite the vast diversity among coastal environments and peoples around the world, the fundamental issues at stake are often similar (e.g. increased user conflicts and competition for limited resources increases). There are usually many ways of addressing a specific policy goal (see Part III) and looking at the coastal legislation of other countries is a very effective way of expanding the range of legal reform options.

\section{Take account of the nature of the coast when designing the governance} framework.

In order for any governance system to be effective it must take account of the nature of who and what is being governed and be adapted to the particular circumstances in which it is to be applied. A law that functions well in one country may be ineffectual in another country that has a different culture, legal tradition and institutions. Law makers may be conscious of the need to take account of social circumstances when designing laws but are often oblivious of the need to take account of the fundamental characteristics of coastal systems when designing ICM laws.

Box 9 gives an indication of how the inherent characteristics of coastal systems have implications for how ICM governance systems should be designed. It also gives examples of some techniques used in national legislation (most of which are discussed in Part III) that reflect these design principles. In many cases a particular legal technique may not have been chosen on the basis of how well it conforms to the characteristics of the coastal area being regulated. However, anyone involved in designing legislation for ICM is likely to design more appropriate and effective legislation by consciously choosing techniques that take account of the fundamental characteristics of coastal systems. 
Box 9

COASTAL CHARACTERISTICS AND LEGISLATIVE DESIGN IMPLICATIONS

\begin{tabular}{|c|c|c|}
\hline $\begin{array}{c}\text { COASTAL } \\
\text { CHARACTERISTIC }\end{array}$ & $\begin{array}{c}\text { DESIGN } \\
\text { IMPLICATIONS }\end{array}$ & $\begin{array}{c}\text { EXAMPLES OF LEGISLATIVE } \\
\text { RESPONSES }\end{array}$ \\
\hline $\begin{array}{l}\text { Coast is a system } \\
\text { in which water is } \\
\text { the unifying factor }\end{array}$ & $\begin{array}{l}\text { - Planning and } \\
\text { authorization } \\
\text { procedures must be } \\
\text { integrated and holistic } \\
\text { (i.e. look at all sectors } \\
\text { and impacts } \\
\text { simultaneously). } \\
\text { - Coast is vulnerable to } \\
\text { cumulative impacts } \\
\text { of upstream activities. } \\
\text { Ecosystem } \\
\text { boundaries usually do } \\
\text { not coincidence with } \\
\text { administrative } \\
\text { boundaries and any } \\
\text { defined coastal area } \\
\text { will affect and be } \\
\text { affected by adjacent } \\
\text { ecosystems } \\
\text { (particularly marine } \\
\text { ecosystems). }\end{array}$ & $\begin{array}{l}\text { - Prioritize preserving the } \\
\text { integrity and functioning of } \\
\text { natural coastal systems. } \\
\text { - Coastal management plans } \\
\text { binding on all sectors and } \\
\text { parties. } \\
\text { - All relevant agencies must be } \\
\text { involved in key permitting } \\
\text { decisions (integrated } \\
\text { permitting). } \\
\text { - Set environmental quality } \\
\text { objectives as coastal } \\
\text { management objectives and } \\
\text { prohibit the authorization of } \\
\text { any upsteam activities that will } \\
\text { prejudice the attainment of } \\
\text { these objectives. } \\
\text { Co-operate with adjacent } \\
\text { administrations and other } \\
\text { States (e.g. notification of } \\
\text { activities with potential } \\
\text { transboundary implications. }\end{array}$ \\
\hline Dynamic & $\begin{array}{l}\text { - Changes in coastal } \\
\text { ecosystems are } \\
\text { inevitable and on- } \\
\text { going so coastal } \\
\text { governance systems } \\
\text { must be flexible and } \\
\text { adaptive enough to } \\
\text { respond to change } \\
\text { (including unforeseen } \\
\text { change). } \\
\text { A long-term } \\
\text { perspective that takes } \\
\text { account of the }\end{array}$ & $\begin{array}{l}\text { - Coastal programmes, plans and } \\
\text { objectives must be reviewed } \\
\text { regularly and must include } \\
\text { systems for monitoring the } \\
\text { state of the coast, evaluating the } \\
\text { effectiveness of management } \\
\text { interventions, feed back } \\
\text { mechanisms (e.g. state of the } \\
\text { coast reports) and amendment } \\
\text { procedures. } \\
\text { Permit conditions must be } \\
\text { capable of review and } \\
\text { amendment. }\end{array}$ \\
\hline
\end{tabular}




\begin{tabular}{|c|c|c|}
\hline $\begin{array}{c}\text { COASTAL } \\
\text { CHARACTERISTIC }\end{array}$ & $\begin{array}{c}\text { DESIGN } \\
\text { IMPLICATIONS }\end{array}$ & $\begin{array}{c}\text { EXAMPLES OF LEGISLATIVE } \\
\text { RESPONSES }\end{array}$ \\
\hline & $\begin{array}{l}\text { interests of future } \\
\text { generations is essential. }\end{array}$ & $\begin{array}{l}\text { - Demarcation of coastal lands } \\
\text { must allow for position of } \\
\text { seashore and coastal } \\
\text { landforms to change. }\end{array}$ \\
\hline Complex & $\begin{array}{l}\text { - Require information } \\
\text { gathering, ana } \\
\text { systems. } \\
\text { - Governance system } \\
\text { must recognize the } \\
\text { limits of our } \\
\text { knowledge and that } \\
\text { the complextiy of the } \\
\text { system means that the } \\
\text { effects of change may } \\
\text { be unpredictable } \\
\text { (non-linear). }\end{array}$ & $\begin{array}{l}\text { EIA and strategic environ- } \\
\text { mental assessment procedures. } \\
\text { - } \text { Rely on more flexible and } \\
\text { adaptive principles as well as } \\
\text { rules. } \\
\text { - Apply precautionary } \\
\text { principle and principle of } \\
\text { preventive action. } \\
\text { - Provide for interim } \\
\text { administrative orders to } \\
\text { protect areas while further } \\
\text { information being gathered. }\end{array}$ \\
\hline diverse & $\begin{array}{l}\text { Protection of } \\
\text { biological and } \\
\text { landscape diversity } \\
\text { must be built into } \\
\text { ICM planning. } \\
\text { - Allow freedom for } \\
\text { development of diverse } \\
\text { management } \\
\text { approaches and local } \\
\text { solutions to local issues. }\end{array}$ & $\begin{array}{l}\text { - Establish protected areas } \\
\text { - Integrated biodiversity } \\
\text { planning as required by the } \\
\text { CBD, and CMPs. } \\
\text { - Decentralize management } \\
\text { (subsidiarity). } \\
\text { - Use a range of management } \\
\text { tools. } \\
\text { - Allow for special management } \\
\text { areas to be established. }\end{array}$ \\
\hline $\begin{array}{l}\text { Powerful nature } \\
\text { forces }\end{array}$ & $\begin{array}{l}\text { - Work with not } \\
\text { against natural } \\
\text { forces and } \\
\text { processes. }\end{array}$ & $\begin{array}{l}\text { - Prohibitions and restrictions on } \\
\text { activities altering long-shore drift. } \\
\text { - Protect coastal landforms } \\
\text { (dunes, etc.) from alteration. } \\
\text { - Establish coastal buffer } \\
\text { zones to protect coastal land } \\
\text { forms and communities } \\
\text { (e.g. from effects of sea level } \\
\text { rise and climate change). }\end{array}$ \\
\hline $\begin{array}{l}\text { Multiple } \\
\text { stakeholders and } \\
\text { users }\end{array}$ & $\begin{array}{l}\text { Participatory } \\
\text { decision-making. } \\
\text { - Share responsibility } \\
\text { for coastal } \\
\text { management. }\end{array}$ & $\begin{array}{l}\text { Mandatory public participation } \\
\text { procedures for preparation of } \\
\text { coastal plans, EIAs and } \\
\text { authorization of potentially } \\
\text { harmful activities in coastal areas. }\end{array}$ \\
\hline
\end{tabular}




\begin{tabular}{|c|c|c|}
\hline $\begin{array}{c}\text { COASTAL } \\
\text { CHARACTERISTIC }\end{array}$ & $\begin{array}{c}\text { DESIGN } \\
\text { IMPLICATIONS }\end{array}$ & $\begin{array}{c}\text { EXAMPLES OF LEGISLATIVE } \\
\text { RESPONSES }\end{array}$ \\
\hline & & $\begin{array}{l}\text { Mandatory consultation } \\
\text { procedures and joint } \\
\text { decision-making structures } \\
\text { within government. } \\
\text { - Impose obligations on all } \\
\text { users to care for coast. } \\
\text { (personal responsibility). } \\
\text { - Encourage co-management } \\
\text { and partnerships for managing } \\
\text { local coastal areas. }\end{array}$ \\
\hline Competing uses & $\begin{array}{l}\text { Regulate to avoid } \\
\text { over-use if demand } \\
\text { for coastal } \\
\text { resources exceeds } \\
\text { supply. } \\
\text { - } \text { Procedures for } \\
\text { avoiding and } \\
\text { resolving } \\
\text { competing claims to } \\
\text { use coastal } \\
\text { resources. }\end{array}$ & $\begin{array}{l}\text { Plans, rules and permitting } \\
\text { systems to keep use within } \\
\text { ecological limits (carrying } \\
\text { capacity). } \\
\text { - Plan to minimize conflicting } \\
\text { coastal uses. } \\
\text { - Allocation criteria and } \\
\text { principles to optimize } \\
\text { resource usage that is } \\
\text { consistent with coastal } \\
\text { management objectives. } \\
\text { Dispute resolution } \\
\text { mechanisms (including } \\
\text { alternative dispute } \\
\text { resolution). }\end{array}$ \\
\hline
\end{tabular}




\section{KEY ISSUES}

\subsection{Introduction}

This chapter discusses some of the most important legal issues that commonly confront anyone seeking to draft legislation to establish an effective ICM system. These include: how to define and demarcate the coastal zone, the legal status of the coast and ownership and use rights in relation to it, resolving jurisdictional issues between institutions involved in coastal management, and dispute resolution. These challenges include both substantive law issues, such as how to define the coastal zone, and procedural issues like creating structures and processes which will produce integrated and consistent policies or for resolving conflicts between competing users. A fuller understanding of some of the legal techniques used to deal with these issues may be gained from reading chapters 6-10.

\subsection{Defining the Coastal Zone}

ICM is concerned with the management of human activities within a specific area of land and sea termed the coast. Accordingly the first fundamental issue that usually confronts proponents of ICM is to decide what is meant by the "coast" and to define a coastal area or coastal zone within which this special integrated management approach is to be implemented.

The coastal area may be defined as "an entity of land and water affected by the biological and physical processes of both the sea and land"108. From an ecological perspective, the coastal area may be described as covering the inner part of the continental shelf, the coastline and a hinterland of at least a few kilometres width. Coastal areas usually include: the surface of the land; the surface of the water; the airspace above the land, the airspace above the sea, the water column, the continental shelf, and the deep sea-bed. Physically coastal fringes are high energy zones with very active and complex dynamics because they include the interface between the atmosphere, hydrosphere and lithosphere. These factors also mean that coastal areas tend to provide habitats for a great variety and number of living organisms, many of which are adapted to live exclusively in coastal environments.

108 GESAMP Glossary, UN Atlas of the Oceans. 
Coastal areas have a "wetside" and a "dryside" and are usually described in relation to defined seaward and landward boundaries - except in the case of islands where it may be appropriate to include the entire landmass within the coastal zone. As Colson has pointed out ${ }^{109}$, strictly speaking the coastal zone should be defined also by reference to a third, airward, boundary, particularly since the airspace is the object of increasing regulation for example with respect to air traffic, physical building regulations and pollution control. However this dimension is not usually mentioned explicitly in national legislation and is usually encompassed within definitions of, for example, the coastal environment.

Although discussions of the boundaries of coastal zones tend to focus on the landward and seaward limits to the axis perpendicular to the shore, it is important to bear in mind that coastal zones also require boundaries on the axis parallel to the shore (except in the case of small island states). The limits to the parallel axis are usually the terrestrial and maritime boundaries between the state and adjacent coastal states. In some cases however these boundaries must be specifically demarcated in the legislation, particularly where not all the coastline is governed by the relevant legislation.

How one defines the coastal area depends on one's perspective, for example as an ecologist, coastal planner or regulator. The GESAMP definition of "coastal area" quoted above continues; "and defined broadly for the purpose of managing the use of natural resources"110. Scientists recognize that coastal ecosystems are essentially variable and dynamic, and regard the use of strict spatial or temporal demarcations as incompatible with these characteristics ${ }^{111}$. On the other hand, the planner or regulator seeks certainty as to exactly where the border of the coastal area is, since this boundary defines the limits within which certain rules and requirements apply. However, coastal areas are very diverse and any attempt to come up with a general rule to determine, for example, the inland limit of the coastal zone is likely to be very inaccurate from an ecological point of view. Hence, the law-

109 Colson J.P. 1987. Le Champ d'Application de la Loi, in Société francaise pour Le Droit de l'environnement, la Loi littoral, Fabrègue s.a., p. 29.

110 GESAMP Glossary, UN Atlas of the Oceans.

111 See Burbridge P. R. and Burbridge V., 1992. Review of the Experiences with Integrated Coastal Management Projects, IUCN, UNEP and WWF, first draft November 1992, page 11, paragraph 4.1. 
maker faces an inherent dilemma - the more precisely the coastal area is defined, the less the definition will encapsulate the intrinsic nature of the coast. Indeed much of the legislation reflects an unresolved struggle between the need for definitional flexibility to reflect the inherently dynamic nature of coastal areas and the precision necessary to create an acceptable degree of legal certainty.

The most common legislative approach is to avoid substantive definitions of the coastal area and to be content with setting landward and/or seaward limits to the application of the nation's coastal area law or management programme, or for the implementation of particular management strategies or tools. Thus in legal terms, "coastal area" often means simply the geographical area demarcated in the legislation as being the area to which the relevant ICM legislation applies.

Nevertheless it is useful to consider briefly some of the different methods used to address this issue. These include:

- using broad conceptual definitions in federal or "framework" legislation which only attain a more geographically precise meaning through the legislative or administrative actions of federal states (e.g. the USA) or subordinate state institutions (e.g. France);

- using a substantive definition coupled with references to boundaries (e.g. India);

- avoiding having to define a coastal area by defining what constitutes coastal public property and the rights and obligations which apply to it and to adjacent land (Spain); and

- combining a precise definition of a core area for certain regulatory purposes with a wider concept which is not precisely defined for policy and management purposes (New Zealand).

Many of the above approaches also include administrative procedures for determining and adjusting the precise positions of the boundaries of coastal $\operatorname{areas}^{112}$.

112 See for example Chapter III of the Spanish Shores Act No. 22/1988, which deals with boundary delimitation proceedings. 


\subsubsection{Substantive Definitions Based on Ecological Features}

Many countries use topographical features or other physical attributes of coastal areas to define the coastal zone, but often in conjunction with references to political or administrative boundaries. For example, the Coastal Protection and Management Act, 1995, of the State of Queensland in Australia, contains the following definition:

"11. The "coastal zone" is

(a) coastal waters; and

(b) all areas to the landward side of coastal waters in which there are physical features, ecological or natural processes or human activities that affect, or potentially affect, the coast or coastal resources."

This definition must be read with the following definitions:

"coastal waters", which means "Queensland waters to the limit of the highest astronomical tide";

"coast", which means "all areas within or neighbouring the foreshore"; and

"coastal resources", which means "the natural and cultural resources of the coastal zone".

The USA's Coastal Zone Management Act (CZMA) defines coastal zones as:

"the coastal waters (including the lands therein and thereunder) and the adjacent shorelands (including the waters therein and thereunder), strongly influenced by each other and in proximity to the shorelines of several coastal states, and includes islands, transitional and intertidal areas, salt marshes, wetlands, and beaches. The zone extends, in Great Lakes waters, to the international boundary between the United States and Canada and, in other areas, seaward to the outer limit of State title and ownership ... The zone extends inland from the shorelines only to the extent necessary to control shorelands, the uses of which have a direct and significant impact on the coastal waters, and to control those geographical areas which are likely to be affected by or vulnerable to sea level rise. Excluded from the coastal zone are lands, the use of which is by law subject solely to the discretion of or which is held in trust by the Federal Government, its officers or agents"113.

The CZMA is a framework law which leaves the actual delineation of zones up to the individual states. Hence there is no single Federal coastal zone in the USA, but separate State coastal zones demarcated in State Coastal

11316 USCA, section 1453(1). 
Management Plans which, while subject to Federal approval, have wide scope for variation. However the CZMA does establish the parameter which States must observe when defining their coastal zone. The seaward boundary is defined by a political boundary (generally speaking the three nautical mile limit of the jurisdiction of States). The inland boundary must be determined with reference to two factors. The first factor limiting the extent of land that may be included in the coastal zone is whether or not the land has a direct influence on the sea, or is directly influenced by it (i.e. sea level rise). The second factor is whether or not it is necessary to control that land for coastal management purposes. In other words, it is clear that the CZMA definition is based primarily on management criteria and that the coastal zone should only include that land which must be controlled in order to be able to control impacts on coastal waters and shorelands. This suggests that the definition is based on the implicit understanding that ICM is concerned primarily with the management of those areas of land and sea that strongly influence one another, rather than on controlling human activities that impact on coastal ecosystems.

In France the coastal areas are defined indirectly by reference to a geographic entity in which the interests of users are interdependent and special management policies are required. The first of the two principal French laws which apply to the coastal area, the Loi littoral, enunciates in its opening article that the coast is "a geographic entity which calls for specific zoning and land-use, protection and development policies"114. The second principal institutes a maritime zoning plan which applies to that "part of the territory that constitutes a geographic and maritime whole and which is the object of competing or complementary interests in the protection, exploitation and management of the shore"115. No geographic criteria are given for determining the delineation of the geographic scope of these laws.

114 Loi no 86-2 du 3 janvier 1986 relative à l'Aménagement, la protection et la mise en valeur du littoral. Article 1 reads: "Le littoral est une entité géographique qui appelle une politique spécifique d'aménagement, de protection et de mise en valeur."

115 Decree No. 86-1252 of 5 December 1986 in execution of article 57 of the Law of 7 January 1983 "relative à la Répartition des Compétences entre les Communes, le Départements, les Régions et les Etats". 


\subsubsection{Substantive Definitions Limited by Boundaries}

The Indian Coastal Regulation Zone Notification of 1991 contains a flexible definition of the coastal zone, but then undercuts this flexibility by using narrow boundary criteria. The area to which the Indian Notification applies is described in ecological terms as comprising "coastal stretches of seas, bays, estuaries, creeks, rivers and backwaters which are influenced by tidal action." However despite this broad definition, in fact the coastal area regulated by this law is very narrow because it is limited by boundaries which reduce the regulated core area to the intertidal zone and an adjacent 500 metre wide strip of land and it lacks an oceanward component ${ }^{116}$.

\subsubsection{Defining Coastal Property Rights}

The 1988 Spanish Shores Act ${ }^{117}$ does not define such concepts as shores, coasts, or coastal zone, but instead enumerates the coastal resources and coastal environments which constitute "coastal public property" ("dominio público maritimo terrestre") ${ }^{118}$ ). They include: (a) the seashore and coastal waters understood as comprising the foreshore (defined as including all coastal wetlands), (b) the beaches, (c) territorial and inland waters, their beds and subsoil, and (d) the natural resources of the economic zone and the continental shelf ${ }^{119}$. In addition certain lands (e.g. land formed by material deposited by the sea or by the sea's receding) are deemed to be coastal public property ${ }^{120}$, as are naturally formed islands in the territorial sea, in inland waters and in rivers as far up as the effects of the ebb tide are noticeable ${ }^{121}$. The deeming provisions are intended to prevent private parties acquiring ownership of land reclaimed from the sea. The precise boundaries of coastal public property are determined by means of boundary delimitation

116 Gazette Notification S.O. No. 114(E) of 20 February 1991, under section 3(1) and section 3(2)(v) of the Environment Protection Act, 1986 and Rule 5(3)(d) of Environment Protection Rules 1986, declaring Coastal Stretches as Coastal Regulation Zone.

117 Ley 22/1988, de 28 julio, de Costas, published in Boletin Oficial del Estado, 29 July 1988.

118 See the bilingual (English-Spanish) publication on the Shores Act, published by the Spanish Ministry of Public Works and Urbanization, March 1989.

119 Section 3.

120 Section 4

121 Section 5 
procedures initiated by the government or at the request of any interested party ${ }^{122}$.

The Act not only introduces a strict regime for this coastal public property but also imposes limitations on the rights of owners of "adjacent private property". These limitations are imposed over zones measured inland from the landward limit of the seashore (which is not defined) and comprise:

(a) a protection easement over a zone 100 metres wide (which may be increased to a maximum of 200 metres in order to accommodate the peculiarities of a particular stretch of the coast) which is designated for public use and in which most other uses, particularly those involving construction, are prohibited;

(b) a right of passage easement of 6 metres wide (which can be extended where necessary to a maximum of 20 metres) which must be kept clear to allow the passage of pedestrians and surveillance or rescue vehicles;

(c) an access to the sea easement of sufficient width to ensure public access to the sea and parking outside the coastal public property zone; and

(d) a zone of influence of at least 500 metres wide in which adequate parking outside the right of passage easement zone must be provided, buildings subjected to controls and waste disposal regulated ${ }^{123}$.

\subsubsection{Using Multiple Definitions}

New Zealand's 1991 Resource Management Act combines a high degree of flexibility for policy and management purposes with legal certainty with respect to the area to which the principal regulatory mechanisms apply. It achieves this by adopting a relatively precise definition of the core area (referred to as the "coastal marine area") while making it clear that this is a component of a larger, undefined area termed the "coastal environment" which is managed under the Act.

122 Sections 11 and 12.

123 See the 1988 Shores Act and Royal Decree 1471/1989, approving the enabling legislation, Reglamento General para Desarrollo y Ejécucion de la Ley 22/1988, published in Boletin Oficial de Estado, 12 December 1989, p. 29127. 
The coastal marine area is defined as:

"that area of the foreshore and seabed -

(a) of which the seaward boundary is the outer limits of the territorial sea;

(b) of which the landward boundary is the line of mean high water springs, except that where that line crosses a river, the landward boundary at that point shall be whichever is the lesser of -

(i) one kilometre upstream of the river; or

(ii) the point upstream that is calculated by multiplying the width of the river mouth by $5 . " 124$

Unless specifically permitted by a rule in a regional coastal plan, coastal permits are required to do a range of things within the coastal marine area including: erecting structures, occupying land, extracting sand or shingle, discharging pollutants into the water or air.

One of the main purposes of the Act is to promote the sustainable management of the "coastal environment" and the Minister of Conservation is required to prepare a national policy statement for the coastal environment. Although the term "coastal environment" is not defined in the Act, its meaning is spelt out in the draft New Zealand Coastal Policy Statement, which defines it as:

"... an environment in which the coast usually is a significant part or element. The coastal environment will vary from place to place depending upon the extent to which it affects or is (directly) affected by coastal processes and the management issue concerned. It includes at least three distinct, but interrelated parts:

- the coastal marine area,

- the active coastal zone, and

- the land backdrop.

The coastal environment includes at least the coastal marine area, the water, plants, animals, and the atmosphere above it, all tidal waters and foreshore whether above or below mean high water springs, dunes, beaches, areas of coastal vegetation and coastal associated animals, areas subject to coastal erosion or flooding, salt marshes, sea cliffs, and coastal wetlands, including estuaries, and in the absence of such features (particularly in the urban areas where the natural shoreline has been modified), all of the land that extends 40 metres inland of the mean high water springs".

124 Section 2 of the 1991 Resource Management Act. 
In conclusion, it is clear that it is essential to have a very clear idea of the purpose for which any definition of a coastal area or zone is required before drafting ICM legislation. Rather than attempting to resolve the dilemma of drafting a definition that is both legally precise and sufficiently flexible to accommodate the realities of the coast, it may be preferable to follow the New Zealand approach and use different definitions for different purposes.

For management and policy purposes, boundaries may not need to be precisely defined and a broad conceptual definition, or no legal definition at all, may be appropriate. Furthermore, the ecosystem approach (see Annex 1) suggests that the focus should be on controlling human activities that negatively impact on coastal ecosystems, wherever these activities occur.

On the other hand, greater precision is required where important rights and obligations are affected by whether or not something is situated or an event occurs, within or outside a particular zone. In such cases it is desirable for the legislation to stipulate clear criteria for determining the extent of each zone within the coastal area and to establish a procedure for determining the exact position of boundaries in specific cases.

\subsection{Demarcating the Coastal Zone}

Most ICM legislation refers implicitly or explicitly to a variety of boundary demarcations, either in lieu of, or in conjunction with, a conceptual definition of the coastal area or zone.

\subsubsection{Seaward Boundary}

There is great variation between countries with respect to the location of the seaward boundaries. This is due in part to the adoption of different sets of criteria for making this selection, most of which can be grouped into one of three categories:

1. political, legal or administrative criteria, such as the outward limit of the national territorial sea (New Zealand, France (implicitly), Spain, Singapore), or the boundary between provincial or state jurisdiction and national jurisdiction (USA);

2. physical landmarks or criteria such as shoreline, continental shelf, tidal marks (Costa Rica and India), and depth or isobath lines (e.g. China and Indonesia); 
3. a combination of arbitrary distances and of physical marks such as an arbitrary oceanward distance in kilometres from a tidal mark (Brazil, Israel, Sri Lanka).

Under international law coastal states have sovereignty over their territorial seas which extend a maximum of 12 nautical miles from a baseline determined in accordance with the 1982 UNCLOS and the rules of customary international law. They may also claim and exercise sovereign rights over an exclusive economic zone (EEZ) of up to 200 nautical miles from the baseline ${ }^{125}$. Sovereign rights may extend even further, in certain cases, where the continental shelf stretches beyond the EEZ, with a maximum outer limit of 350 nautical miles from the territorial baseline ${ }^{126}$.

Although the use of the boundary criteria for various internationally accepted marine zones referred to in 1982 UNCLOS (e.g. internal waters, the territorial sea, and the EEZ) has been advocated as a method of delimiting the seaward boundary of national coastal areas, in practice no single method of determining the marine boundary of the coastal area has been widely adopted. Box 10 gives an indication of the wide range of seaward boundaries which have been adopted or are proposed, in national legislation dealing with coastal areas.

As appears from the comparative table in Box 10, several national coastal area management laws take as the maximum seaward boundary, the outer limit of the nation's territorial sea ${ }^{127}$. This is a logical choice since under international law the coastal state exercises full sovereignty over this area, and in most countries the majority of the productive and extractive activities which have an impact on the coast take place within 12 nautical miles of the coast.

125 See 1982 United Nations Convention on the Law of the Sea, (UNCLOS), articles 55-57.

126 UNCLOS Article $76 \mathrm{ff}$. For further discussion of these concepts, O'Connel D.P., The International Law of the Sea, vol. I, 1982 Clarendon Press, pp. 553-582.

127 See Freestone D., ICZM: The problem of Boundaries, in Status of Integrated Coastal Zone Management, CAMPNET (Coastal Area Management and Planning Network) Publication, 1991, Clark J. R (ed), p. 75. 
Box 10

SEAWARD BOUNDARIES

\begin{tabular}{|l|l|}
\hline Costa Rica & Mean sea level ${ }^{128}$ \\
\hline India & Low tide line ${ }^{129}$ \\
\hline Israel & 500 metres from Mean low tide ${ }^{130}$ \\
\hline New Zealand & 12 nautical miles of the territorial sea si1 $^{131}$ \\
\hline Sri Lanka & 2 kilometres seaward from the Mean Low Water line ${ }^{132}$ \\
\hline USA & $\begin{array}{l}\text { The limit of the three nautical mile territorial sea in which, by } \\
\text { Federal law, the States own the submerged lands and } \\
\text { resources }\end{array}$ \\
\hline
\end{tabular}

5.3.2. Landward Boundary

There is even less uniformity with respect to the landward boundaries of coastal areas in national legislation than the seaward boundaries (see Box 11). Scientists generally favour extending the landward boundary sufficiently far inland to include those areas that influence, or are influenced by, the sea or coastline in an ecological sense. This may involve including an entire watershed, as was done in California. Although this approach may make sense from the point of view of managing ecosystems, it is too imprecise and extensive to provide a workable basis for controlling various activities such as building development on the coast. As a result most ICM legislation seeks to achieve greater legal certainty in this regard by demarcating a landward boundary fairly close to the shoreline, typically a stipulated distance inland from a tidal baseline. This usually defines the core zone to which the most

128 Pleamar ordinaria, as defined in article 9, Law of 2 March 1977.

129 Notification S.O. No. 114(E), 19 February 1991, under section 3(1) and section 3(2)(v) of the Environment Protection Act, 1986 and Rule 5(3)(d) of Environment Protection Rules 1986, declaring Coastal Stretches as Coastal Regulation Zone.

130 See Sorenson J.C. et al. Institutional Arrangements for Management of Coastal Resources, p. 10.

131 Resource Management Act 1991.

132 Coast Conservation Act No. 57 of 1981, article 42.

13316 USCA, section 1453(1). 
stringent regulations apply though it may be part of a larger coastal area for management purpose.

As appears from Box 11, even between states which follow this approach the baselines vary and include mean high water, mean high water springs and the highest tidal line for a decade ${ }^{134}$.

134 It should be noted that simply referring to high or low tide lines is technically imprecise. The Admiralty Tide Tables published by the Hydrographer of the Navy in the U.K. (Vol. 3, 1989, p. xxviii) refers to the following categories of high and low tide:

"(a) H.A.T. (Highest Astronomical Tide). L.A.T. (Lowest Astronomical Tide). The highest and lowest levels respectively which can be predicted to occur under average meteorological conditions and under any combination of astronomical conditions; these levels will not be reached every year. H.A.T. and L.A.T. are not the extreme levels which can be reached as storm surges may cause considerably higher and lower levels to occur.

(b) M.H.W.S. (Mean High Water Springs). M.L.W.S. (Mean Low Water Springs). The height of mean high water springs is the average, throughout a year when the average maximum declination of the moon is 23.5 degrees, of the heights of two successive high waters during the period of 24 hours (approximately once a fortnight) when the range of the tide is greatest. The height of mean low water springs is the average height obtained by the two successive low waters during the same period.

(c) M.H.W.N. (Mean High Water Neaps). M.L.W.N. (Mean Low Water Neaps). The height of mean high water neaps is the average, throughout a year as defined in (b) above, of the heights of two successive high waters during those periods (approximately once a fortnight) when the range of the tide is least. The height of mean low water neaps is the average height obtained by the two successive low waters during the same period." 
Box 11

LANDWARD BOUNDARIES

\begin{tabular}{|l|l|}
\hline Costa Rica & 200 metres from mean high tide ${ }^{135}$ \\
\hline Cuba & Limits for each of 6 coastal types ${ }^{136}$ \\
\hline India & Up to 500 metres from the High Tide Line ${ }^{137}$ \\
\hline New Zealand & $\begin{array}{l}\text { Line of the Mean High Water Springs, or where this line crosses } \\
\text { a river, the lesser of the point situated at one kilometre upstream } \\
\text { or the point obtained by multiplying the width of the river mouth } \\
\text { by five }{ }^{138}\end{array}$ \\
\hline Sri Lanka & $\begin{array}{l}300 \text { metres inland from the Mean High Water Line and two } \\
\text { kilometres inland measured perpendicular to the straight baseline } \\
\text { between the natural entrance point up rivers, streams, lagoons or } \\
\text { other bodies of water connected to the sea permanently or } \\
\text { periodically } 139\end{array}$ \\
\hline
\end{tabular}

1351977 Law on the Zona Maritimo Terrestre, article 9.

136 Decree-Law No. 212 of 8 August 2000, articles 4 and 5.

137 Notification S.O. No. 114(E), 19 February 1991, op cit. The notification defines the coastal regulation zone as extending inland from the low tide line and including "the coastal stretches of seas, bays, estuaries, creeks, rivers, and backwaters which are influenced by tidal action ... up to 500 metres from the High Tide Line" (which is defined as the line up to which the highest high tide reaches at spring tides).

138 This is the landward boundary of the "coastal marine area" as defined in Section 2 of the Resource Management Act. However the Act requires development of coastal areas to occur in accordance with the New Zealand Coastal Policy Statement which applies to the "coastal environment" which is not defined in the Act".

1391981 Coastal Conservation Act, article 42. 


\begin{tabular}{|l|l|}
\hline U.S.A & $\begin{array}{l}\text { Inland from the shorelines (not defined) of states "only to the } \\
\text { extent necessary to control shorelands, the uses of which have a } \\
\text { direct and significant impact on the coastal waters, and to control } \\
\text { those geographical areas which are likely to be affected by or } \\
\text { vulnerable to sea level rise"140 } \\
\text { This has been applied by states in various ways }\end{array}$ \\
& $\begin{array}{l}\text { California: Variable Line depending on the issues (since 1977) } \\
\text { formerly highest elevation of nearest mountain; } \\
\text { Washington: } 200 \text { feet from Mean High Water mark for regulation } \\
\text { purposes (planning controls extend to the inland boundaries of } \\
\text { coastal counties); } \\
\text { Florida, American Samoa, Guam, Northern Mariana Islands: } \\
\text { Entire state or territory }{ }^{142} \text {. }\end{array}$
\end{tabular}

\subsection{Rights to Own and Use Coastal Areas}

Among the most fundamental issues to be addressed in preparing ICM legislation is determining the nature and extent of rights to own and use coastal areas that will be recognized in law, and who will hold these rights. In most legal systems these rights will already be well established prior to the implementation of ICM and there may be limited scope to change them. However it is important that ICM policy-makers appreciate the nature and function of both the existing property regimes and of other regimes under consideration, and the importance of establishing proper governance systems in relation to each of them. Serious policy errors can occur if these issues are misunderstood. For example, Mathiews (1995) argues that the complete collapse of the cod fishery in Newfoundland is at least partially attributable to an inappropriate Canadian Federal fisheries policy which was heavily influenced by Hardin's "Tragedy of the commons" thesis. Hardin incorrectly equated common ownership with open access to a resource and concluded that, as population grew, overexploitation of the resource was inevitable. As a result, Canadian Federal fisheries authorities were prejudiced against existing common property regimes managed on a local basis by inshore

140 Coastal Zone Management Act, section 16, USCA 1453(1) as amended in 1990.

141 Archer, 1988, p. 9; Sorensen et al., 1990, p. 10; Malone L.A. The Coastal Zone Management Act and the Takings Clause in the 1990s: Making the Case Work for Federal Land Use to Preserve Coastal Areas, Colorado Law Review, Vol. 62. No. 4, p. 715. 142 Sorensen et al., 1990, p. 10. 
fishing communities. Consequently they introduced a federal licensing system designed to restrict the number of individuals involved in fishing (rather than, for example, limiting the activity of large offshore trawlers). This policy was spectacularly unsuccessful in preventing the overexploitation of the resource which eventually collapsed. The domestic fishery was closed by the Canadian government in 1992.

\subsubsection{Nature of Ownership}

Concepts of ownership and the rights flowing from it vary from jurisdiction to jurisdiction. However, the fundamental principles of ownership in most jurisdictions today are often remarkably similar. Ownership is generally understood as being like a container holding a number of rights in relation to the property in question. For example, the owner of immovable property (land and buildings) would usually have the right to possess the land, to use it, to enjoy its fruits such as crops or rent, and to dispose of it.

The owner may transfer one or more of these rights to other parties for a period and still retain the "container" (i.e. ownership) with the result that these rights will revert to the owner eventually.

Property rights are created and enforced by society for particular purposes. They define the relationship between a person (an individual or a legal entity such as a company) and a thing. Legal systems typically classify types of ownership on the basis of both the subject (i.e. the owner) and the object of the right. The categories vary between legal systems, but most incorporate distinctions between:

(a) things that cannot be owned (for example air or the sea which are common to everyone (res communes) and property such as the seashore which is held by the state for the benefit of the public (res publicae));

(b) things that are unowned but can be owned, such as wildlife or fish before they are captured (res nullius); and

(c) things that may be freely bought and sold.

Property rights regimes are often analyzed on the basis of the various categories of persons who hold the right. This obscures the fact that the characteristics of the property regime are determined both by the category of person holding the right (e.g. the state, a private individual or legal entity, or 
a group with common rights) and by the nature of the property (thing) in question. For example, characterising all land held by the state as "state land" may obscure the fact that some of this land cannot be sold and is held for the benefit of the public, and some of it may be capable of being bought and sold by the state in the same way as can be done by a private land owner.

\subsubsection{Ownership in Coastal Areas}

Typically in a coastal area there will be a mixture of many forms of ownership. The land comprising the seashore and the immediately adjacent foreshore, and the land submerged under estuaries, rivers and territorial seas are usually publicly owned and incapable of private ownership. Other land in the coastal area is usually capable of being privately owned although in fact it may be owned by the state or by public bodies such as municipalities.

In most countries, the shoreline or a substantial part of it is legally defined as common public property or as inalienable state property held on behalf of the people ${ }^{143}$. In addition there are often public servitudes over adjacent land to facilitate access to, transit through, and use of the seashore ${ }^{144}$.

This classification has several advantages; in particular it helps to maintain the integrity of the coast and to ensure that the present and future generations can use beaches and other coastal resources without social discrimination ${ }^{145}$. The main disadvantage is that because the concept embodies the idea that the public has a legal right to use the area, it can be difficult to control negative effects arising from undesirably intensive public use. For example, intensive recreational use of coastal areas can cause environmental degradation and conflicts between different users and between visitors and inhabitants of the coast.

143 A variety of forms of collective public land tenure exist in different legal systems, for example res omnium communes, domain publique, crown lands and public trust lands.

144 See for example the 1988 Spanish Shores Act.

145 See Chaverri, R. 1991. The Coastal Public Zone: The promise of the premise, CAMPNET, pp. 66-68. 


\subsubsection{Use rights in Coastal Areas}

From an ICM perspective use rights are critical, and ownership is often relevant mainly insofar as it determines who may use a coastal area and who has the right to control that usage.

In relation to a particular natural resource the following rights can be identified:

1. the right of access to it;

2. the right to use, exploit or withdraw it;

3. the right to manage the resource, in the sense of the right to regulate the internal use patterns and to transform the resource by making improvements (e.g. the right to build and develop);

4. the right to determine exclusion, namely decide who may have access to it an on what terms; and

5. the right to alienate the resource ${ }^{146}$.

In the absence of legislation to the contrary, the owner would hold all of these rights unless they had been redistributed to other parties such as an authorized user.

From an ICM perspective, it is important to determine not only what the legal position is, but also what the factual reality of the situation is. Parties may hold rights that they do not exercise or enforce. For example, regardless of whether an area is subject to state, common, or private ownership, if noone controls access to it and anyone can use it, it will be used as an open access resource and is likely to be over-exploited.

\subsubsection{Customary Law Regimes}

Frequently existing property regimes have been superimposed on traditional customary legal systems which, until recently, were often simply ignored. Many unwritten customary law systems do not emphasize private ownership

146 Schlager, E. and Ostrom, E. 1992. Property Rights and Natural Resources, A Conceptual Framework, Land Economics, vol. 68, No. 3, August 1992, p. 249. 
and indeed some take the view that the people belong to the land rather than vice versa. Customary law systems typically emphasize the responsibilities of humans in relation to the environment that sustains them, and are more concerned with the equitable allocation of rights to harvest renewable resources from a communally owned or occupied territory. There has been a trend in recent years to recognize both some of the traditional legal rights asserted by indigenous people and also that the principles which they embody may be useful in promoting the sustainable management and equitable allocation of natural resources ${ }^{147}$.

In some countries, customary law systems still play an important role in regulating the use of coastal areas. For example, in South Africa Xhosa chiefs still allocate land within traditional communities along the Wild Coast in the Eastern Cape Province, and traditional use rights are important in regulating the fishing practices of the Tonga people in the Kosi Bay Lake system in the KwaZulu-Natal Province. However the potential for the abuse of such systems, particularly by outsiders, exists. For example, there were numerous examples of outsiders bribing chief in order to be granted rights to build holiday homes on traditional lands along the Wild Coast before the practice was halted by the courts ${ }^{148}$.

In New Zealand customary rights threatened to play an unexpectedly large role in coastal management. It had long been assumed that the Crown owned the foreshore and seabed except where it had specifically granted title to others. But in 2003 the Court of Appeal ruled that indigenous rights were not necessarily extinguished ${ }^{149}$. The Government reacted by introducing

147 The recognition that traditional use rights in fisheries (TURFs) and other customary forms of tenure in the coastal zone, successfully ensured sustainable use and management of coastal resources has lead some countries in the Pacific to begin investigating ways to give legal recognition to the customary rights of local communities. In Japan, traditional fishing rights, originally controlled by village leaders, have now been transferred to village-based cooperatives and in Papua New Guinea local enforcement of customary use right systems are permitted within specially designated "Wildlife Management Areas". See Wells S., Traditional Management in the Pacific, CAMPNET, 1991, pp. 72-74.

148 See WESSA $v$ Minister of Environmental Affairs and Tourism, 1996 (3) SA 1095 (Tk SC).

149 Attorney-General $v$ Ngati Apa [2003] 3 NZLR 643 (CA) see Seabed and Foreshore Issue, Coastal News, Issue 26, July 2004, p. 11. 
legislation to ensure general public access to the seabed and foreshore. The resulting Foreshore and Seabed Act, 2004 confirms Crown ownership of the seabed and foreshore ${ }^{150}$. It provides for a "foreshore and seabed reserve" to be created ${ }^{151}$ in areas where a group has held "territorial customary rights"152 defined in part as exclusive use and occupation without substantial interruption since $1840^{153}$. The companion Resource Management (Foreshore and Seabed) Amendment Act, 2004 provides for the recognition of customary rights in coastal zone decision-making as well as for control over their exercise ${ }^{154}$.

\subsubsection{Changing Rights to Use and Manage Coastal Resources}

\section{Analysing and clarifying rights}

In order to successfully establish ICM it is essential that there is legal clarity as to who is entitled to use and control the use of the natural resources in the coastal area, and who actually does so. In some cases legislative intervention may be necessary to limit or redistribute some of these rights to achieve ICM objectives.

From an ICM perspective, rather than classifying property rights on the basis of legal or economic categories, it is more useful to identify:

(a) who has the legal right to control access to a particular resource;

(b) whether or not the use of the resource is in fact controlled and if so, by whom and on what basis; and

(c) the terms on which access is granted.

In some cases legislative intervention may be necessary in order to clarify ownership and use rights. In South Africa during the colonial period strips of land inland of the high water mark had been demarcated in some coastal areas as "admiralty reserve" land. Much of this land was owned by the State

150 Foreshore and Seaben Act, section 4.

151 Ibid., section 43.

152 Ibid., section 33.

153 Ibid., section 32.

154 Resource Management (Foreshore and Seabed) Amendment Act, 2004. 
but in some cases the deeds for privately owned properties indicated that a portion of the property was designated as admiralty reserve. The precise reason for establishing an admiralty reserve and the legal status of these areas became unclear over time. The generally accepted view was that it was not permissible to build on admiralty reserve land but in many cases where this was done, those responsible were not prosecuted. The draft coastal management legislation in South Africa seeks to clarify the situation by defining state-owned admiralty reserve land to be coastal public property and by incorporating privately owned admiralty reserve land into a buffer zone within which building restrictions apply.

\section{Restricting and redistributing rights}

If it is clear that the existing property regime in the coastal zone will obstruct or prevent the attainment of the objectives of the ICM programme, it will be necessary to restrict or redistribute the relevant rights.

In many countries it is permissible to restrict existing private use rights provided that this is done for a public purpose, in a reasonable and nondiscriminatory manner and by means of a law that applies to everyone. For example, the rights of a private owner of land in the coastal zone to build on it may be restricted by a later law that prohibits building in the coastal zone unless an EIA has been conducted and authorization granted. In such cases the private landowner would usually not be entitled to compensation.

The situation is different when a government redistributes rights in the sense of taking an existing right away from someone and retaining it for itself or granting it to another. In such situations there has been a "taking" of a right and the person from whom the right was taken may well be entitled to compensation from the State. The viability of an ICM initiative may well depend on whether or not it will involve paying significant amounts of compensation. A less satisfactory solution is to limit the application of coastal zone laws to publicly owned land as has been done in Costa Rica.

In deciding whether or not to introduce legislation to change ownership or use rights in coastal areas it is helpful to consider the following questions:

1. to what extent is the existing distribution of public and private ownership of coastal land and resources conducive to attaining ICM objectives generally and in particular, protection of environmental 
quality and long term sustainable development, including ensuring inter-generational equity and equitable access and use for the current generation?

2. are further limitations on the existing rights of private owners necessary and justifiable to attain ICM policy goals?

3. should any rights be expropriated and compensation paid in order to achieve ICM policy goals?

4. to what extent have customary rights of common ownership or use been affected and is it appropriate and useful to incorporate or recognize these in any new regime?

5. is access to public or state-owned coastal areas being managed by institutions with appropriate powers and responsibilities, and are there effective mechanisms for holding them publicly accountable?

6. are new legal concepts (such as custodianship or trusteeship) required to effect the required changes?

Some of the legal mechanisms that can be used to effect the distribution or redistribution of rights to own and use coastal resources include:

(a) using fundamental legal principles that may already exist in the legal system to reasserting public ownership and control over coastal areas;

(b) initiating expropriation or acquisition programmes to bring important areas under public ownership or control;

(c) recognizing customary, or indigenous rights over resources and devolving certain powers to manage those resources to traditional authorities or local organizations representing users; and

(d) imposing restrictions on private ownership rights for example by providing for public servitudes or easements over private land to facilitate access to the sea-shore and requiring land owners to obtain official authorization for undertaking certain activities, particularly where these are likely to have a significant impact on the coastal landscape and environment. 


\subsection{Conflict Reduction and Resolution}

One of the defining characteristics of coastal zones is that they contain valuable resources and a high level of human activity. Increasingly the human demand for access to the benefits produced by coastal ecosystems exceeds supply. The situation is further exacerbated when some uses of coastal areas have a negative impact on others (e.g. manufacturing plants may pollute coastal waters used for mariculture). This inevitably leads to competing and conflicting claims over access to these resources. Where the governance regime for coastal areas is organized on a sectoral basis and is poorly integrated, the different priorities of the agencies concerned will also tend to generate conflicts.

One of the fundamental goals of ICM is to reduce conflicts between users of the coast and between different sectors and levels of government. Accordingly, any institutional structures established as part of an ICM initiative should be designed with this objective in mind. Indeed it has been argued that the goal of establishing institutions for managing coastal resources "is to create an organizational climate that can help anticipate, avoid or resolve conflicts that dissipate the value of coastal resources and environments" 155 .

Therefore an important function of ICM legislation is to create institutional arrangements and establish procedures which, firstly, reduce the potential for conflict, and secondly, facilitate the resolution of those conflicts that do arise.

In most legal systems the courts resolve conflicts by applying relatively inflexible legal rules to each situation in order to determine which party's case is superior in law thereby producing a winner and a loser. However in the case of many conflicts which arise in an ICM context, such as competition for the use of a particular part of the coast, it is not possible or even desirable, to stipulate definite rules to determine who is "right". Resolving conflicts of this nature requires a balancing of interests in the context of a wide range of flexible criteria, which themselves may not be wholly consistent. Consequently various alternative dispute resolution techniques, such as conciliation, mediation and some arbitration procedures,

155 Sorensen et al., 1990, p. 98. 
which aim to produce a result acceptable to all the parties involved, are likely to be more effective in the ICM context ${ }^{156}$.

Examples of situations in which such techniques have been used or proposed ${ }^{157}$ include:

(a) the use by the Environmental Protection Agency in the USA of trained facilitators to structure and conduct formal discussions between interested parties to produce policies, negotiated rules and environmental standards; and

(b) the use of mediators to resolve conflicts between fishing and oil interests over geophysical testing and the location of vessel traffic lanes in the Santa Barbara area of California.

\subsection{Jurisdictional Issues}

The functions, powers and responsibilities of government agencies are established by legislation and accordingly, if these need to be clarified or altered in order to achieve ICM, legislative intervention is necessary. Indeed an essential role of ICM legislation is to clarify and delimit the jurisdictions of the various organs of the State and other institutions involved in any ICM regime. If the parameters of each government agency's area of responsibility are not clearly defined, conflicts are likely to arise both between different tiers of government claiming jurisdiction in respect of the same matter ("vertical overlap") and between different sectoral agencies operating in coastal areas ("horizontal overlap"). For example, in a federal state, a lack of clarity as to the seaward limits of the respective jurisdictions of national and sub-national units ${ }^{158}$ is likely to lead to a vertical conflict concerning which body should be allowed to manage, use and reap the profit of economic activities in the coastal waters.

156 Part E (Conflict Resolution in Integrated Coastal Area Management) of the FAO Guidelines (1998) provides valuable guidance in this regard.

157 Cited by Sorensen et al. (1990), pp. 108-110.

158 The terms national and sub-national as used in this study refer to the highest government level (or the highest national level) and to the level immediately under this (sub-national), without particular connotation of whether the nation has a centralized or decentralized system of government. 
Jurisdictional conflicts can be reduced by:

- involving all government agencies with management responsibilities for human activities that affect the coast in the process of preparing ICM policies and programmes that they are required to implement or be guided by;

- ensuring that coastal management programmes, policies and plans at each level are consistent with those at other levels (e.g. local CMPs must be consistent with provincial CMPS which must be consistent with the national CMP) in order to achieve vertical policy consistency;

- ensuring that all agencies must give effect to, and act in accordance with, the applicable CMP in order to achieve consistent implementation, both horizontally across sectors, and vertically between different levels of government;

- defining the roles of different agencies in implementing the various aspects of the CMP clearly, taking care to distinguish between situations in which a particular agency: (i) may take decisions without reference to other agencies; (ii) must take decisions jointly with other agencies; or (iii) must act as the lead agency and consult with other agencies, but need not follow their recommendations;

- clarifying which institutions and officials will be responsible for enforcement, (particularly controlling negative environmental impacts which arise outside the coastal area), and the legal basis and extent of their powers;

- establishing structures to facilitate the regular meeting, exchange of information and co-ordination of the activities of the agencies involved; and

- establishing mechanisms for resolving inter-agency jurisdictional disputes.

There will inevitably be overlaps between the jurisdictions of different sectoral agencies in the coastal area. In addressing these from a legislative perspective the aim should not be to eliminate all overlaps but rather to reduce administrative inefficiencies and duplications to a minimum by ensuring the simultaneous involvement of all relevant agencies in decisionmaking processes such as the granting of permits. 
PART III

LEGAL APPROACHES AND TECHNIQUES 


\section{APPROACHES TO ICM LEGISLATION IN NATIONAL LAW}

\subsection{Introduction}

Historically ICM programmes have tended to emerge in the context of growing recognition that the existing sectoral system for the management of coastal resources is inadequate and that a more holistic and integrated approach is required (see section 1.1). In Australia, the significant changes in coastal management that occurred during the 1990s appear to have been triggered by four factors: (i) global environmental change, (ii) adoption of the principles of sustainable development, (iii) the application of strategic planning principles as a result of pressure for a more holistic approach to the management of natural resources, and (iv) greater public awareness and participation in decision-making ${ }^{159}$.

However it is important to note that not all legislation which in fact introduces a degree of ICM is enacted with this express purpose. Legislation designed to achieve more limited objectives may also result in a particular part of the coast being managed in an integrated manner. Alternatively a national ICM system may result from a legislative programme with a far broader purpose (such as natural resource management in the case of New Zealand and environmental protection in the case of Sweden).

Even where an awareness of the inadequacies of sectoral coastal management exists, it does not necessarily lead to the enactment of ICM legislation. Some countries have taken a conscious decision not to enact comprehensive legislation and instead seek to achieve ICM by coordinating existing laws and policies via inter-agency guidelines (e.g. Western Australia). Other countries have opted to start by reforming the institutional rather than the legal framework, often by designating or creating a government agency with authority over the coastal zone (e.g. British Virgin Islands, Sri Lanka, Western Australia).

159 Thom, B.G. and Harvey, N. 2000. Triggers for late twentieth century reform of Australian coastal management, Australian Geographical Studies, 38, pp. 275-290, as quoted by Morcom, N., 2002. Approaches for Integrating Coastal Management in South Australia, Coast to Coast, pp. 299-302. 
Some countries (e.g. United Kingdom and Ireland) have considered ICM but have never introduced it, apparently because of the magnitude of the legal and institutional changes and political effort that would be required to overcome the resistance and inertia of long-established institutions organized on a sectoral basis. However the publication of the European Community recommendation on integrated coastal zone management (see Box 4) appears to have re-ignited moves towards ICM in both Ireland and the United Kingdom.

\subsection{Types of Approaches}

Although the forces shaping ICM legislation are different in each jurisdiction, the resultant legislation can usually be classified into one of following categories according to the intention of the legislator and the means chosen to produce the desired result:

1. the "national integrated coastal management approach" where legislation is enacted specifically to implement or promote existing ICM policies (e.g. USA);

2. the "sustainable development approach" which has given rise to ICM as part of a wider purpose to achieve sustainable development (e.g. Sweden) or the sustainable management of natural resources (e.g. New Zealand) throughout the country;

3. the "extended land-use planning approach" characterized by attempts to modify terrestrial planning techniques to achieve more integrated management of coastal areas (e.g. France); and

4. the "special region approach" which is characterized by the implementation of integrated management of coastal resources within particular regions of the coastal area in order to achieve specific objectives which are more limited in scope than those typical of a full ICM programme.

Of these approaches, only the first two can be considered to be truly integrated and national in scope and only the first one is primarily motivated by the specific intention to implement ICM on a national scale (although the second approach may well also achieve this purpose). 


\subsection{National Integrated Coastal Management Approach}

The distinguishing feature of this approach is that the legislation in question has been enacted with the specific purpose of implementing ICM. Consequently it applies to both the marine and terrestrial environments and regulates both human activities and resource management on the one hand and environmental conservation on the other hand. The best example is the ICM regime in the USA.

\subsubsection{USA}

In the USA, the Federal Coastal Zone Management Act of 1972 (CZMA) ${ }^{160}$ is often cited as a good example of collaborative Federal/state coastal area management and planning ${ }^{161}$. The CZMA establishes a Federal programme that encourages coastal States, including those along the Great Lakes, to enact a coastal zone management programme in accordance with the minimum federal requirements.

States are induced to enter into this voluntary partnership with the Federal government by two basic incentives: substantial Federal funding and the ability to exercise a degree of control over Federal government activities in the coastal zone by means of the "consistency" provisions, (explained below). On the other hand the Federal government acquires the ability to ensure that States give attention to national priorities by having the power to approve State programmes and to monitor their implementation, backed up by the sanction of withdrawing access to Federal funds.

A State must submit its Coastal Management Program (CMP) to the US Secretary of Commerce for approval before it can become eligible for a grant ${ }^{162}$. Even before this submission, the National Oceanic and Atmospheric Administration (NOAA) of the Department of Commerce will have provided initial funding and will have been actively involved in the

160 Coastal Zone Management Act, Public Law No. 92-583, 86 Stat. 1280 (1972) codified at 16 USCA 1451, et seq; Last re-authorized by the Coastal Zone Management Act Reauthorization Act of 1990, Public Law No. 101-508, 』 6204, 104 stat. 1388.

161 The major goals of the US CZMA are set out in Box 12.

16216 USCA S $1455(\mathrm{a})$. 
development of the programme. Approval will not be given unless the State CMP conforms to a series of general and specific substantive requirements (see Box 12). The CMP must also be accompanied by an environmental impact statement prepared in accordance with the guidelines of the Environmental Policy Act.

After approval, the NOAA continues to evaluate and monitor the State programmes for funding purposes ${ }^{163}$ and Federal aid for the development and for the implementation of a CMP may be withdrawn if it ceases to comply with Federal requirements.

These Federal powers are offset by the CZMA consistency provisions, namely the stipulation that Federal agencies must function in ways that are consistent with State programmes. The consistency mechanism separates Federal activities into two broad categories. The first one contains activities that a Federal agency is conducting or supporting which directly affect the coastal zone, and development projects undertaken by a Federal agency in the coastal zone. These activities must be conducted in a manner which is "to the maximum extent practicable" consistent with approved CMPs ${ }^{164}$. The second category covers those activities which affect land and water uses in the coastal zone and require a Federal permit, and those projects in respect of which state or local governments apply for Federal permission and assistance. The CZMA stipulates that Federal permission may not be granted unless the state or its designated agency certifies that the proposed activity complies with the State's CMP and that the activity will be conducted in a matter consistent with the programme ${ }^{165}$, which thus allows the State to exercise a veto ${ }^{166}$. There are exceptions for unusual circumstances such as reasons of national security.

163 Grants are made to a State to enable it to develop a final management programme, and once approved, the State is eligible for further grants to implement and administer the programme, pursuant to sections 305 and 306 of the CZMA, 16 USCA 1454(a) and 1455(a).

16416 USCA $\$ 1456(\mathrm{c})(1)$ and (2).

16516 USCA \$1456(d) [CZMA section 307]

166 See on the Federal Consistency doctrine, Beyle L. J., 1989. A Comparison of the Federal Consistency Doctrine under the FLPMA and the CZMA, Virginia Law Review, vol. 9, p. 211; and Malone, 1991, pp. 731 and 732. 


\section{Box 12}

\section{U.S. FEDERAL REQUIREMENTS FOR STATE COASTAL MANAgEMENT PROgRAMMES}

\section{General Requirements ${ }^{167}$}

1. The programme must provide for the management of coastal waters and adjacent shorelands the uses of which have a direct and significant impact on coastal waters, or which are likely to be vulnerable to sea level rise, and the taking of steps to assure appropriate protection of significant resources and areas, such as wetlands, beaches, dunes, and barrier islands, that make the States' coastal zone a unique, vulnerable, or valuable area.

2. The programme must contain three broad classes of policies that are related to resources protection, management of coastal development and simplification of governmental processes.

3. The policies must be appropriate to the nature and degree of management related to uses, areas, and resources identified as subject to the programme;

4. The policies, standards, objectives, criteria, and procedures by which programme decisions will be made must provide a clear understanding of the content of the programme, especially in identifying who will be affected by the programme and how, as well as a clear sense of direction and predictability for decision makers who must take actions pursuant to or consistent with the management programme.

\section{Specific substantive requirements ${ }^{168}$}

Each State's CMP programme must include:

(a) an identification of the boundaries of the coastal zone subject to the programme;

(b) a definition of what constitutes permissible land and water uses that have a direct and significant impact on the coastal waters;

(c) an inventory of the areas of particular concern;

(d) an identification of the means to exert control, including a list of relevant legislation;

(e) broad guidelines on priorities of uses in particular areas including specifically those of lowest priority;

16716 USCA \$1452(2) [CZMA, section 303(2)]

16816 USCA $\int 14555(d)(2)$ See Malone, op cit., p. 720-723. 
(f) a description of the organizational structure proposed to implement the programme, including responsibilities and interrelationships of local, area-wide, state, regional and interstate agencies in the management process;

(g) a definition of the term "beach" and a planning process for the protection of, and access to, public beaches and other public coastal areas of environmental, recreational, historical, aesthetic, ecological or cultural value;

(h) a planning process for energy facilities likely to be located in, or which may significantly affect the coastal zone; and

(i) a planning process to assess the effects of shoreline erosion and to study ways to control or lessen the impact of erosion and to restore areas adversely affected.

The CZMA authorizes coastal States to choose among the following three approaches to achieve the goals of the Act $^{169}$ :

(a) local government implementation, according to standards established by the State, subject to State administrative review and enforcement;

(b) direct State water use planning and regulation; or

(c) State review of development plans and projects, and land and water use regulations, prepared by any State agency or by private developers, with the power to approve or disapprove.

All of these techniques, tailored to local conditions, are usually combined in the States' CMPs. Some States have enacted comprehensive CMP legislation with broad review authority by State agencies (California, South Carolina). Other states (North Carolina, Washington) have encouraged decentralized local management plans, whereas still others (Florida and Wisconsin) implement their CMPs through a statewide network of agencies.

One of the deficiencies of the coastal management system in the USA is the exclusion of the fisheries sector and of most of the seaward dimension in the States' CMPs. This is the result of the Federal-State jurisdictional boundaries in the territorial sea. Under Federal Law, coastal State ownership rights are

16916 USCA §14555(d)(11) [CZMA 』306(e)]. 
restricted to the submerged lands and resources in the zone extending three nautical miles from shore. This restriction was incorporated in the CZMA, and hence the seaward boundary of the states' CMP is restricted to the three nautical miles zone of the US territorial sea ${ }^{170}$. Regional fisheries Councils regulate the fisheries sector in the 200 miles EEZ or Fisheries Conservation zone. Consequently, the States' CMPs typically address land use patterns and tend to under-emphasize the water related uses of the coastal zone ${ }^{171}$.

The Federal-State collaborative framework in the USA (unlike the system in New Zealand) is voluntary, in that there is no obligation for the States to enact a CMP. However, the fact that, since 1972, thirty-four of the thirty-five USA Coastal States and territories eligible for participation have implemented comprehensive and Federally approved coastal zone management programmes ${ }^{172}$, illustrates how well Federal authorities have succeeded in inducing States to conform to national standards and priorities regarding an area which is predominantly within the jurisdiction of the individual States. However there appears to be little prospect of State CMPs being extended seaward beyond three miles to include offshore marine resources located within the 12 mile territorial sea let alone within the 200 mile EEZ. The result has been numerous disputes among States, the

170 Under the Submerged Lands Act (SLA), passed in 1953, states were granted quitclaim title to the lands three miles seaward of the coastline (43 USC, S\$13011315 (1988). In 1845 the Supreme Court decided in the case of Pollard's Lessee $v$ Hagan, (44 USC 212, 1845) that the States held title to the submerged lands of all navigable waters including those in the coastal zone. Under the Continental Shelf Lands Act (OCLSA), 43 USC, \$1331-1356 (1988) the Federal government has jurisdiction over the continental shelf beyond the three miles zone, see Malone, 1991, p. 735.

171 Archer, 1988, p. 6.

172 United States Office of Management and Budget, Coastal Zone Management Act Programs Assessment (www.whitehouse.gov). 
Federal government and development interests regarding Federal offshore oil and gas licensing programs ${ }^{173}$.

\subsection{The Sustainable Development Approach}

Some countries have enacted legislation with the specific purpose of achieving sustainable development and use of natural resources throughout the country rather than only in coastal areas. Although the main motivation for enacting this legislation was not to implement ICM, the comprehensive and holistic nature of this approach is consistent with ICM and consequently when implemented it tends to have the effect of promoting ICM. The main advantage of this approach is the fact that policy integration occurs at the highest level.

\subsubsection{New Zealand}

In New Zealand, a new regime for the coastal zone has emerged as a result of the enactment of the Resource Management Act of 1991 (RMA). The Act is the product of a comprehensive legislative review process, and represents a major overhaul of the previous legislative framework, amending or repealing some 50 separate Acts, mostly affecting the coast and the marine environment.

The RMA aims at establishing a partnership between the State (or Crown), on the one hand, and the regional and district councils on the other hand. To this end, a new administrative structure came into effect in October 1991, which includes a hierarchy or "cascade" of planning instruments.

At the top of the hierarchy is the RMA itself, the purpose of which is to promote sustainable management of New Zealand's natural and physical

173 See Archer, 1988, p. 9; and Malone, 1991, pp. 735 ff. on the conflicts between the national interest in energy production and the states' environmental concerns, particularly because of aggressively pursued Federal licensing programs in the continental shelf. The literature on the subject leaves the impression that the prevalence of the national (Federal) interest in the continental shelf, leaves the States autonomy and some Federal funding only to deal with the consequences on their coastal zone of Federally licensed activities, but does not give them enough power to enable them to participate in planning and decision-making. 
resources. It sets out matters of national importance that must be recognized and provided for in the different policy statements and plans. These include:

"(a) the preservation of the natural character of the coastal environment (including the coastal marine area), wetlands, and lakes and rivers and their margins, and the protection of them from inappropriate subdivision, use and development; ...

(b) the maintenance and enhancement of public access to and along the coastal marine area, lakes and rivers" 174 .

It also singles out a number of other national priorities such as the efficient use of natural and physical resources and makes consideration of the rights of the indigenous population mandatory.

The next tier is formed by national policy statements (NPS) on a variety of issues, which are subject to the terms and purposes of the RMA. Only one national policy statement is mandatory: under section 58 of the RMA, the Minister of Conservation is required to enact a national policy statement on New Zealand's Coastal Zone (NZCPS). The NZCPS was finalized after being submitted to two rounds of public review. Its role is to provide detailed guidance on the requirements of the 1991 RMA and on government policy decisions through the policy and planning instruments of regional and district councils. The NZCPS also defines the relationships between the Crown, 12 regional councils, 5 unitary councils (combining powers of the region and the district), and the district councils.

On the next level down, regional coastal policy statements (RCPSs) and plans are required for the whole of the coastal marine area (i.e. the land, water, and air between the mean high water springs and the 12-mile territorial sea limit). These RCPSs are to be developed by regional councils in consultation with the Minister of Conservation and must incorporate the principles of the NZCPS and be consistent with the RMA. The Minister must approve such plans before they can come into force and may intervene to suggest matters that RCPs should deal with, make formal submissions when each plan is released for comment, and refer a plan to the Planning Tribunal. Regional councils may also regulate any other matter within their competence through other regional plans.

174 RMA, Part II, section 6. 
The final level of the hierarchy is the mandatory district plans, prepared by district councils for the area of the coastal environment above the mean high water springs. These must be consistent with all plans and acts of a higher level. The Minister may intervene through council hearings and has the right to refer such plans to the Planning Tribunal.

A far reaching mechanism introduced by the RMA requires that before policy statements and plans at all levels are implemented they must be evaluated to determine if they are necessary, if there are alternatives available and to gauge their efficiency and effectiveness ${ }^{175}$. In addition, all plans are to be monitored as to their effectiveness upon implementation, and must be independently reviewed within 10 years.

It is clear from the above that mandatory statutory provisions and the establishment of priorities by the central government are central to the ICM regime in New Zealand. The intervention by the Minister of Conservation in local coastal planning and policies is justified for two reasons ${ }^{176}$. First, as landowner of most of the foreshore and seabed which is not in private ownership, the Crown seeks to maintain its interest in the coastal marine area by ensuring sustainable use. Second, the Crown as landowner represents the

175 Section 32 provides that in relation to the preparation of NZCPS or approving RCPs, before adopting any objective, policy, rule or other method, the Minister of Conservation must evaluate it "to determine: (1) the extent to which policy/statement is necessary to achieve the purposes of the Act; (2) other means in addition to or in place of such objective, policy, rule or other method which, under this Act or any other enactment, may be used in achieving the purpose of this Act, including the provision of information, services, or incentives, and the levying of charges (including rates)", Meister, A.D. and Rosier, D.J. 1992. An Evaluation framework for the New Zealand Coastal Policy Statement, published by Department of Conservation, Science and Research, Series No. 53, pp. 17 and 18.

176 Draft New Zealand Coastal Policy Statement, Department of Conservation, Wellington, 1992, p. 26. 
national interest, which may require specific inclusion of some matters in the regional coastal plans ${ }^{177}$.

Significantly, fisheries are a neglected dimension of the New Zealand legislative frameworks as is the case in the USA but for different reasons. In New Zealand this is due to a decision early in the legislative review process to review the fisheries sector separately. It is probable that the future enactment of new fisheries law will lead to some amendments of the RMA and of the New Zealand Coastal Policy Statement.

\section{Sweden}

In Sweden, after almost a decade of work 15 Acts were replaced by an Environmental Code containing 33 chapters and almost 500 sections, which entered into force on 1 January 1999. The Swedish government decided to codify the law relating to the environment for three main reasons. Firstly, the many different Acts, many with different rules and permit requirements, meant that the regulatory structure was difficult to comprehend and to comply with; secondly some environmentally harmful activities (e.g. roads and railways) were inadequately regulated, and thirdly new environmental problems had emerged such as diffuse sources of pollution ${ }^{178}$. It is significant that from the outset one of the main objectives of the legal reform process was to create a more integrated governance system based as far as possible on common principles and rules.

Section 1 states that the purpose of the Code is "to promote sustainable development which will assure a healthy and sound environment for present and future generations" (see Box 13). Chapter 2 then sets out fundamental "rules of consideration" that apply, in principle, to all human activities that may harm the environment, and must be applied by everyone, even if public

177 Other examples of the prerogatives of the Crown are the power of the Minister of Conservation to designate activities or uses in the coastal marine area as restricted (as a transitional measure in the absence of a regional coastal plan), and the power of the Minister for the Environment to set nationwide environmental standards, prepare other national policy statements, and to "call in" particularly contentious proposals for his decision.

178 The Environmental Code. 1998. A summary of the Government Bill on the Environmental Code (1997/98:45), Regeringsansliet, Stockholm, pp. 1 and 2. 
authorities are not involved. Both the purpose of the Code and the rules of consideration are consistent with the basic principles of the ICM approach, and therefore when the Code is implemented in coastal areas it promotes ICM.

In addition, the provisions of the Code relating to the management of land and water areas have the effect of recognizing that coastal areas require special protection and a special management approach. For example, the Code provides that areas must be used for the purposes for which they are best suited in view of their nature and situation, and of existing needs ${ }^{179}$. Areas of particular natural or cultural value or that are particularly suitable for certain uses (e.g. commercial fishing, aquaculture, or recreation) must be protected against measures that may prejudice these values or uses, particularly if the value or use in question is in the national interest ${ }^{180}$. Many coastal areas and archipelagos have been protected on this basis as areas in which natural and cultural assets of national interest occur, and consequently tourism and outdoor recreation are given priority over other uses of these areas ${ }^{181}$. The Code also makes specific provision for the protection of the shores of the sea, inland lakes and watercourses by establishing a shore protection zone (usually

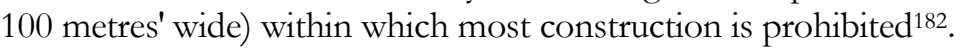

\section{Box 13}

\section{EXTRACTS FROM THE SWEDISH ENVIRONMENTAL CODE, 1998}

\section{Chapter 1 - Objectives and area of application of the Code}

"Section 1. The purpose of this Code is to promote sustainable development which will assure a healthy and sound environment for present and future generations. Such development will be based on recognition of the fact that nature is worthy of protection and that our right to modify and exploit nature carries with it a responsibility for wise management of natural resources.

The Environmental Code shall be applied in such a way as to ensure that:

- human health and the environment are protected against damage and detriment, whether caused by pollutants or other impacts;

179 Environmental Code, Chapter 3, section 1.

180 Ibid., Chapter 3.

181 Ibid., Chapter 4.

182 Environmental Code, Chapter 7, sections 13-16. 
- valuable natural and cultural environments are protected and preserved;

- biological diversity is preserved;

- the use of land, water and the physical environment in general is such as to secure a long term good management in ecological, social, cultural and economic terms; and

- re-use and recycling as well as other management of materials, raw materials and energy are encouraged with the view to establishing and maintaining natural cycles."

Chapter 3 - Basic provisions concerning the management of land and water areas

"Section 1. Land and water areas shall be used for the purposes for which the areas are best suited in view of their nature and situation and of existing needs. Priority shall be given to use that promotes good management from the point of view of public interest." ...

\section{Chapter 7 - Protection of areas}

"Section 1. Any person who exercises the right of access to private land or is in the countryside for any other reason shall treat it with due care and consideration." ...

"Section 13. Shore protection applies by the sea, lakes and watercourses. The purpose of shore protection is to assure public access to outdoor recreation facilities and to maintain good living conditions for plant and animal species on land and in water."

\subsection{The Extended Land-Use Planning Approach}

Nation- or State-wide land-use planning and regulation for the coastal zone is probably the most frequently used management strategy found in national legislation regulating coastal areas. Many countries have either enacted new legislation or amended existing legislation, in order to adapt existing legal frameworks for land-use planning and development control to coastal management requirements. This approach has the advantage of being easier to implement in that it tends to rely on existing institutions and to reform, rather than replace, the existing approach to governance. However these strengths are also the weaknesses of this approach in that established ways of thinking about land-use planning and control tend to dominate at the expense of ICM principles. From an ICM perspective there is a limit to how much can be achieved by reforming a system designed for terrestrial planning and development control instead of coastal management. 


\subsubsection{France}

The French legislation on ICM is interesting in that it is based on two separate laws, which together could conceivably cover the entire coastal zone. One law prescribes rules for local terrestrial zoning schemes while the other one introduces a State-initiated and State-sanctioned maritime zoning plan.

The special provisions instituted in respect of the Languedoc-Rousillon area (discussed below under the special areas approach) can be seen as an early forerunner of legal changes designed to accommodate the unique features of the coastal area. In 1979 a modest directive introduced the first amendments dealing specifically with the coast to the general zoning and land-use law (in the Code de l'urbanisme). This was followed by the introduction of the two most important legal instruments regulating the French coastal zone. The first is a law of 7 January 1983 primarily concerned with the regulation of the marine environment which introduced a system of plans for enhancing and exploiting the sea (Schémas de Mise en Valeur de la Mer or "SMVM"). The second is the 1986 Seashore Act (Loi littoral) which is essentially a land-use planning law.

An SMVM is a plan that zones areas of the coastal sea and adjacent land according to use and indicates options for future development of the area ${ }^{183}$. The concept was introduced by a law which reorganized the distribution of powers between the territorial subdivisions of the French nation (communes, départements, régions and the State) ${ }^{184}$. Legally speaking an SMVM is classified as a prescription particuliere, which denotes that it is a norm imposed at the national level, by the central State authority working through its territorial delegate, the Préfet du Départment ${ }^{185}$. As such it is superior to all local terrestrial zoning plans drawn up by communes ${ }^{186}$ such as the Plans d'Occupation des Sols

183 Some authorities suggest that the SMVM should be conceived as a classification of uses of the coastal sea (un zonage de la mer cotière) containing the major options to be followed, much as a schéma directeur under the Code de l'urbanisme; see Becet and Le Morvan, 1991, p. 148.

184 Article 57 of the Law of 7 January 1983.

185 Under the French constitutional and administrative system after the reform Law of 7 January 1983, every département manages local affairs within its own budget but is at the same time a subdivision of the central government. See International Environment Reporter 231:0101.

186 Communes are the smallest administrative unit in Belgium, France, Italy and Switzerland and are governed by a mayor and a council. 
(POS). In other words, all documents concerning urbanization (Code de l'urbanisme), land use and zoning must conform to the SMVM.

The law is silent as to who actually initiates the procedure to prepare an SMVM, but indicates that the SMVM is to be adopted under the control of the prefet, who must consult with local public authorities and private interest groups. The first step in preparing a SMVM involves conducting an initial study and the preparation of a report, after which the administrative phase begins. This involves four stages. The prefet first delimits the boundaries of the study scheme in an Order (Arrêtê), with the concurrence of the preffet maritime, and after consultation of the towns and villages concerned (communes), as well as public regional authorities. During the second stage, studies are undertaken and the results submitted to a working group of local interests. The third stage involves publishing proposals for public comment for a certain period and then submitting the proposals together with the comments received and the agreement of the préfet maritime $e^{187}$ to the Minister in charge of maritime affairs. Finally, after a statutory process involving a

187 The eventual plan submitted to the Minister must include a report, accompanied by maps and diagrams, and specified Annexes. The report must contain: (1) an analysis of the geographical delimitation; (2) perspectives for the evolution of the environment; (3) the definition of, and justification for the options chosen in relation to infrastructure, protection, and development; (4) a determination of the future general use of the zones: industrial and harbour development, marine cultures, leisure areas, (5) details on the future uses of the different sectors of the maritime area, their consequences, the interactions, and the conditions for compatibility of the coastal and maritime uses; (6) details of the zoning and land-use plans in existence; (7) detailed measures for the protection of the marine environment; (8) rules for adjoining maritime, riparian and terrestrial areas; and (9) an indication of how the SMVM respects national and particular requirements of the Code de l'urbanisme. The maps and diagrams must indicate graphically: (1) the characteristics of the marine environment; (2) the utilization of maritime and terrestrial areas or zones; (3) development trends for the different sectors; (4) the areas which benefit from special protection, and (5) the location of existing and envisaged infrastructure. The Annexes must include: (1) a list and summary of the studies conducted; (2) a specific note on the water problems and (3) a note on marine erosion. 
public inquiry, the plan is adopted by means of a decree of the Minister in charge of maritime affairs ${ }^{188}$.

The Loi littoral 189 on the other hand, pertains mainly to terrestrial aspects of the coastal zone. It modifies the general French zoning and land-use laws contained in the Code de l'urbanisme to take account of the unique nature of the coastal zone. In preparing a POS the land-use planning authorities in each commune are required by the Loi littoral to comply with the following national principles.

1. Firstly urban expansion must be controlled. This means that future urban growth should be in continuity with existing urban zones, or villages or hamlets, and in harmony with the environment ${ }^{190}$. In zones close to the shore, limited urban expansion is allowed on the condition that this is provided for in the POS and that it is justified by the configuration of the site or that the construction or economic activity is water-dependent ${ }^{191}$. In any event, the law provides for a shoreland exclusion zone of 100 metres (la bande littorale non constructible).

2. Secondly urbanized zones must be interspersed with natural areas. The law stipulates that the communal zoning plans must provide for natural zones as a break (coupure) in urbanization ${ }^{192}$.

3. The most sensitive areas (remarkable or characteristic sites) must be protected from urbanization ${ }^{193}$. Only light construction is allowed in

188 SMVM planning appears to have progressed slowly and six years after its introduction into the law only four SMVM were in the study phase, according to Becet and Le Morvan, op cit., p. 139 who mention the planned SMVM for the Bay of Audierne (Finistère), the Bay of Bourgneuf, the Bay of Lannion, and the Lake of Than.

189 Loi No 86-2 of 3 January 1986, Journal officiel, 4 January 1986, p. 200.

190 Article 3, Loi littoral, new article 146-4, Code de l'urbanisme.

191 Principle of limited extension of the urbanization see new article 164-4 Code de l'urbanisme and following.

192 New article L. 146-2, al. 4, Code de l'urbanisme. 
such areas, if necessary for the management of the zone, for economic development or access of the public ${ }^{194}$. The decree concerning the organization of public inquiries is applicable to these "light" works ${ }^{195}$. The report accompanying the proposal for a POS must explain what is planned for these remarkable or characteristic sites, and decisions will necessarily be taken on a case-by-case basis ${ }^{196}$.

One of the fundamental problems with the French system is that the legislation does not clarify the relationship between the essentially marine approach of the SMVM system and the terrestrial planning system under the Loi littoral. According to the enabling legislation, the SMVM is to be applied to that part of the territory that constitutes a geographic and maritime unity and that is the object of linked, competing or complementary interests with respect to the protection, exploitation or management of the coast ${ }^{197}$. This definition contains two clues for the possible delimitation of the SMVM: it

193 "Remarkable or characteristic sites and landscapes belonging to the natural and cultural heritage, and those environments necessary for the maintenance of the biological balances" according to article 3 Loi littoral, article 146-6 in the Code de l'urbanisme. The habitats and environments identified as worthy of protection in decree no 89-694 of 20 September 1989 (which implements article 3 of the Loi littoral) include: dunes, beaches, adjacent cliffs and areas; woods and forested zones near the seashore, small uninhabited islands, the natural parts of estuaries, and capes; the coastal wetlands; the environments which accommodate natural concentrations of animal and plant species; resting, nesting and refuge places of water fowl; remarkable geological formations, mineral and fossil deposits, caves; coral reefs, lagoons and mangroves.

194 Article 3, Loi littoral, 146-6, Code de l'urbanisme; Becet \& Le Morvan, op cit., p. 153 cite footpaths, movable equipment destined for reception and information of the public, or activities allowing for a certain degree of economic development: agricultural activities, fishing, marine cultures, pastoral or forest activities.

195 Decree No. 85-453 of 23 April 1985 in execution of the Law of 12 July 1983 concerning the democratization of public inquiries and protection of the environment, Journal official of 24 April 1985, p. 4753, as amended by the Decree No. 89-694 of 20 September 1989.

196 Becet \& Le Morvan, 1991, p. 136.

197 Article 1 of Decree 86-1252 of 5 December 1986. 
should cover the land/water interface, and it should regulate human activities that place different demands on that interface ${ }^{198}$.

In the absence of any other indications in the law, and in order to reconcile the SMVM with the legislation covering the land, commentators have concluded that the geographical scope of the SMVM, as a maritime document, needs to be conceived as starting from a certain seaward limit and extending landwards. French doctrine tackles the problem by starting from the principle that the SMVM should not duplicate terrestrial documents such as local zoning plans (POS). However there is considerable jurisprudential controversy in France as to the seaward reach of the POS.

One school of thought argues that since the State is the principal owner of: the intertidal zone or foreshore, the seabed, the Continental Shelf, and its natural or artificial superstructures ${ }^{199}$ (pursuant to the doctrine of the domaine public maritime) and since under the French Constitution the entire territory of the nation is taken up by communes, it follows that the communes' territory extends to the limits of the territorial sea ${ }^{200}$. Furthermore, in the 1973 Schwetzoff case ${ }^{201}$ the Conseil $d^{\prime} E t a t{ }^{202}$ decided that the POS needed to include development activities in the coastal fringe. This raises the possibility of duplication by the POS of activities to be covered by the SMVM and possible conflicts between the two. However even if the POS does cover activities in the coastal fringe, it is clear that the freedom of action of the communes is restricted, and becomes more so the closer a project is situated to the water.

198 See Becet \& Le Morvan, 1991, p. 148.

199 "... le rivage, le sol, le sous-sol de la mer territoriale, les lais et relais de la mer et les terrains endigués" ; Authority over the Domaine Public Maritime is exercised through the Préfet, see Becet \& Le Morvan, 1991, p. 13.

200 Article 2 of the French Constitution of 1985: "La France est une République indivisible" and article 72 which has as implication that the national territory is divided in collectivités territoriales, more precisely in communes. See Becet \& Le Morvan, 1991, p. 104.

201 Ministre de l'Aménagement du Territoire, de l'Equipement, du Logement et du Tourisme $v$ Schwetzoff, 30 mars 1973, Rec. p. 264; AJDA, 1973, p. 336. The case concerned the building of a marina in the coastal fringe. The Conseil d'etat held that constructions erected on the domaine public maritime were illegal if not provided for by the commune's zoning plan.

202 The Conseil d'etat is the highest administrative tribunal in France. 
The weaknesses of the French system arguably stem from the failure of the lawmakers to undertake more radical legislative reform based on an understanding of the rationale for introducing truly integrated coastal management. For example, an integrated approach is hampered by the lack of clarity as to how the SMVM scheme fits in with other laws affecting the coastal zone. Nevertheless, in spite of the weaknesses of the SMVM system, the wide scope of the plans may lead to an integrated management plan for coastal waters and foreshore which will promote integrated management of the whole coastal area.

\subsection{The Special Region Approach}

Historically this approach has usually arisen in situations in which a national authority decides that in respect of a particular region of the coast it will depart from the usual management regime and adopt a multi-sectoral approach in order to address certain pressing issues more effectively. Typically the decision to adopt a more integrated approach is prompted by the realization that the issues at hand cannot be effectively resolved within the existing institutional framework because they extend into the jurisdiction of more than one existing institution.

Examples include:

(a) the development of harbour plans to reduce bureaucratic inefficiencies in harbour areas in the USA;

(b) programmes to restrict urban encroachment into sensitive areas (e.g. the New Jersey Pinelands Protection programme);

(c) plans to preserve the value of an area as a tourist destination (e.g. the regional plan for the Languedoc-Roussillon region on the French Atlantic coast); and

(d) programmes to conserve and manage valuable resources (e.g. the Banc d'Arguin national park in Mauritania).

Very often the region serves as a laboratory for developing or amending broader national ICM legislation, or for testing particular national coastal management strategies. 


\subsubsection{Regional Harbour Plans}

Regional harbour plans in the USA were probably the earliest attempt to integrate the management of a portion of the coast. These tended to concentrate on a narrow set of issues and are very often aimed at simplifying permit applications by establishing so-called "one-stop" or "single-window" procedures. These have tended to be regulated by agreement between State and local government institutions and other concerned citizens groups rather than by legislation. However they are worthy of consideration because they played an important role in the processes that led to the eventual enactment of comprehensive ICM legislation in the USA.

The first attempt to implement an integrated system for managing a coastal area was by the San Francisco Bay Conservation and Development Commission which was created by the State of California in 1965. The Commission consisted of a range of representatives of local governments, agencies and citizens groups. It promulgated the San Francisco Bay Plan which stipulated that no project which would lead to blocking of public access or filling of the San Francisco bay area within 100 feet from the shore, would be permitted without a permit from the Commission. This local plan was partially responsible for the enactment of the first national ICM legislation in 1972 - the US Federal Coastal Zone Management Act (CZMA) ${ }^{203}$.

The Grays Harbor Estuary Management plan of Washington State, implemented in the 1970s was also instrumental in the encouragement of Special Area Management efforts on a national scale in the USA ${ }^{204}$. The plan's goal was to integrate a multiplicity of policies and procedures for water and land use permits. This was achieved by the conclusion of a long-term agreement between State, local and Federal interests which established the Grays Harbor Estuary Management Task Force which included

203 This Act is discussed in more detail in section 6.3 above.

204 The plan resulted in amendments to the Federal CZMA and the Clean Water Act, section 404 (dredge and fill clause) see Walters Ch. K., Management Planning in Coastal Areas: The Process, in Brower D. J. and Carol D.S. (ed.), Managing Land-use Conflicts, Case Studies in Special Area Management, Duke Press Policy Studies, Durham 1987, p. 1. 
representatives of developers, conservation groups and of the Washington State Coastal Zone Management Citizen Advisory Groups.

Similar concerns were the basis for implementing the Baltimore Harbor Environmental Enhancement Plan in 1982 in Maryland, USA. It was devised to reconcile conflicting views on the evaluation of applications for construction works, dredge and fill permits and different uses in the harbour area. The area identified in the plan covered the tidal portion of Patapsco River, (i.e. the international Baltimore port, Baltimore City, and the Anne Arundel and Baltimore counties). The plan was developed by a task force set up within the Regional Planning Council (a Baltimore area-wide planning agency), and reviewed by the Coastal Zone Metropolitan Advisory Board. The latter included representatives from citizens, government, special interest groups from the coastal jurisdiction in the Baltimore region, and from the Maryland State Coastal Resources Advisory Committee. Eventually a letter of understanding was signed by all parties concerned (Federal, state and local agencies), to implement a co-ordinated approach to the core issues identified in the plan 205 .

\subsubsection{The Languedoc-Roussillon Region in France}

The Languedoc-Roussillon coast covers an area of 200 kilometres between the Camargue and the Pyrenées. It has precious coastal resources such as fine sandy beaches and rocky shorelines, and is home to bird populations such as herons and pink flamingos. Long considered a mosquito-infested area, its development began in earnest with the setting up in 1963 of an inter-ministerial committee devoted to the promotion of tourism. Soon, major construction works were initiated for tourism infrastructure: access routes, marinas, eradication of mosquitoes, reforestation, sanitization of lakes, etc. One of the major goals of the area project was to prevent the linear physical development that is so characteristic of the Cote d'Azur. Therefore from the outset one of the objectives was the alternation of urban zones and natural ones, a principle termed "discontinuity of urbanization" which was to be implemented by zoning plans at several levels.

205 See Dolan M., Baltimore Harbor Environmental Enhancement Plan, in Brower and Carol, op cit., pp. 94-113. 
As a first task, the interministerial commission enacted a regional management plan in 1964 (Plan d'Urbanisme d'Intéret Régional or "PUIR"), spanning four coastal départements (Pyrenées-Orientales, Aude, Gard, Hérault) and providing for five tourism units to be alternated with natural zones206. Each unit was to be built following plans by different architects, giving priority to a concern for balanced and controlled urban development. The units were to be separated from each other by zones classified as zones with a special natural value: agricultural zones, forest regions, or protected areas.

In 1972 the PUIR was replaced by a Schéma Directeur d'Aménagement du Littoral (SDAL), which confirmed the major decisions taken in the PUIR and classified the area into the following zones:

1. growth areas for all coastal towns (zones d'agglomération du littora);

2. forestry zones comprising natural forests, existing and planned artificial forests (zones de boisement);

3. protected natural areas - delineated so as to preserve the minimum amount of natural areas considered necessary for the development of tourism without impeding regional development (zones de nature protégees);

4. protected tourist areas - in general constituted of agricultural zones in which the development of an infrastructure for tourism is permitted but not ordinary residential development (zones de protection touristique); and

5. infrastructural areas - comprising highway infrastructure and marinas (les équipements d'infrastructure).

Four main types of legal measures are used to protect and manage this coastal area:

(a) laws on zoning and land use, which classified some areas on the basis of the dominant use (e.g. natural zones, agricultural zones or urbanized zones);

206 Le Grau-du Roi-Palavas, bassin de Thau, Valras-Gruissan, Leucate-Le Barcarès, Canet-Argèles. 
(b) the law on the protection of sites (sites classés) which applies to sites that have particular artistic, historic, legendary or picturesque value ${ }^{207}$;

(c) the law on the protection of nature, or "reserves naturelles"208; and

(d) the designation by the regional territorial authority (the département de l'Hérault) of environmentally sensitive buffer zones ("périmètres sensibles" subsequently replaced by the term "espaces naturels sensibles") 209 .

The département was originally authorized to exercise a right of preemption for the sale of territory within the périmètre sensible, but under the newer régime, the département is empowered to initiate a policy for the management of, and public access to, these designated areas. Since 1982, the département de l'Hérault has collaborated with Conservatoire du littoral for the acquisition of territory along the coast.

The evolution in the mix of legal mechanisms used reveals a very clear progression from sectoral management to more integrated planning, suggesting that the regional experiments in Languedoc-Rousillon were a precursor to French national legal developments with respect to ICM. Indeed the primary objectives of the early French coastal zone legislation ${ }^{210}$ (the combating of linear coastal urbanization or physical development; the organization and control of urbanization by alternating urbanized and natural zones, and shoreland exclusion or restriction) had already been incorporated

207 Loi 2 mai 1930 relative à la protection des monuments naturels et des sites de caractère artistique, historique, légendaire on pittoresque, Journal officiel, 4 May 1930. p. 5002. By 2003127 sites in the area had benefited from this classification, including: natural environments such as capes (Cap de l'Abeille), lakes (Etang de l'Or), landscapes (Panorama depuis la voie littorale-étang de l'Or), and cultural sites such as a seaman's cemetery and chapel (cimetière marin et chapelle des Auqils) and a park and ruins around a cathedral (parc qui entoure la cathédrale avec les ruines de l'Evechê). See Direction régionale de l'environnement Languedoc-Roussillon, Sites et paysages: méthdologie, classement et inscription (2003).

208 Loi of 10 July 1976, which revived article 9 bis of the Law of 2 May 1930 on nature reserves, No. 76-629 of 10 July 1876, Journal officiel, of 12 July, p. 4203.

209 Amended by Loi No. 85-729 of 18 July 1985, Journal officiel, p. 8152.

210 As laid down in the Circulaire of 4 August 1976, (Journal officiel of 6 August 1876, p. 4758) and the Directive of 25 August 1979, ("... sur la protection et l'aménagement du littoral", Journal officiel, 26 August 1979, p. 2099). 
into the regional zoning plans for Languedoc-Roussillon (PUIR 1964 and SDAL 1972).

\subsubsection{Protection of Wetlands and Other Critical Habitats}

Many examples of the special area approach are motivated primarily by the desire to preserve or protect vulnerable coastal ecosystems or habitats without any attempt to integrate this with the management of other uses of the coast. Therefore in the absence of a wider ICM initiative the reservation of a portion of the coastal area in which no development is permitted and public use rights (e.g. of access and to fish) are curtailed, can be evidence of a sectoral rather than an integrated approach. However some projects which are predominately conservationist in nature have resulted in what amounts to ICM within a special area.

In South Africa the public outcry in response to attempts to mine sand dunes along the Indian Ocean coast in the Lake St. Lucia protected area created the impetus for establishing a more extensive and integrated management regime for the area. The fact that Lake St. Lucia was listed as a wetland of international importance under the Ramsar Convention, was an important factor in inducing the government to intervene to prevent the mining company exercising its existing right to mine the area. The government was also influenced by arguments that conserving the area and promoting tourism would result in more sustainable job creation than mining would. A successful application was then made to UNESCO to list a much larger area, centred on the original Lake St Lucia game reserve, as a world heritage site under the World Heritage Convention. South Africa also enacted the World Heritage Convention Act in order to implement the World Heritage Convention. Powers under this Act were then used to establish the Greater St Lucia Authority with extensive management powers over a large area. 


\section{TECHNIQUES FOR ADDRESSING KEY GOVERNANCE ISSUES}

\subsection{Introduction}

A range of legal techniques or instruments can be used to achieve specific ICM objectives. This chapter deals with legal techniques that can be used to address key governance issues such as achieving integrated planning, the devolution of power, the management of information and funding. The next four chapters discuss legal techniques that can be used: to preserve the integrity and public character of the coast (chapter 8), to guide the development of infrastructure (chapter 9); to encourage the sustainable use of coastal resources (chapter 10); and to increase compliance (chapter 11). The main purpose of these chapters is to give an indication of the range of legal techniques that can be applied to achieve particular ICM objectives so that legal drafters and ICM policy makers can make more informed choices when designing national legal frameworks for ICM.

Although legislation is one of the instruments for implementing policy most favoured by governments, it must always be borne in mind that legal techniques are only part of the spectrum of policy instruments available to governments, and are not always the best means of achieving every objective. The ranges of policy instruments usually available to governments to achieve ICM objectives include ${ }^{211}$ :

- direct government investment which may take the form of "hard" investments in physical infrastructure such as water treatment plants, or "soft" investments in areas like training, research and public education;

- institutional restructuring;

- "command and control" legal instruments which require those to whom the law applies to act in a particular way and which rely for their effectiveness on enforcement mechanisms (e.g. inspectors) and the imposition of sanctions on transgressors;

- economic or market-based instruments which create financial incentives or disincentives in order to encourage the desired behaviour; and

211 See FAO, 1998, p. 75, Box A.26. 
- societal instruments like the promotion of civil society organizations or allowing citizens to institute court actions to protect the environment.

\subsection{Identifying and Using Appropriate Legal Techniques}

In choosing among different techniques, it is important to be guided by the principles on which the ICM approach is based (see section 2.2), any specific principles identified by the national ICM programme, and by any principles and objectives of the legal reform process itself (see section 4.3). For example, a legal reform programme might identify several options for establishing a coastal planning system. One option would be for the law to require provincial governments to prepare provincial coastal management programmes that give effect to a national coastal management programme. A second option would be to establish a procedure whereby local communities, citizens and community-based organizations are entitled to participate in the formulation of local coastal management programmes within broad frameworks established by the national or provincial government. Both these approaches may be effective in achieving the objective of establishing a comprehensive coastal planning system. However, if the relevant national ICM programme incorporates a principle of devolving management responsibility as far as possible and encouraging public participation, this would tend to suggest that the second option should be preferred.

Although the legal techniques discussed have been grouped into categories, it is important to appreciate that a particular technique is often used to achieve more than one objective. For example, environmental impact assessment may be used primarily to achieve coastal development control objectives, but may also function as an important technique for ensuring public participation and involvement in coastal management. In many instances, there will be several techniques that could be used to achieve a particular policy objective. It is also important to note that the list of techniques proposed here is merely indicative of some of the legal techniques available and should not be regarded as an exhaustive list. Furthermore, the techniques are not mutually exclusive and in many situations the best option may be to use a combination of techniques rather than choosing one.

It is also important to appreciate that, while learning from the experiences of other countries is extremely valuable, simply replicating a foreign technique in national laws is likely to be ineffective. How a law functions is heavily influenced by its legal, political, institutional and social environment and the 
same rule or technique will not work in the same way under different conditions. In other words, it is always important to consider the extent to which a technique should be adapted or "translated" so that it will function better within the legal environment into which it is being received.

\subsection{Formulating Integrated Coastal Policies}

\subsubsection{The Importance of Integrated CMPs}

In order for there to be an integrated approach to coastal management it is essential that there is a single comprehensive vision for the coast and a policy which sets out mutually consistent goals and objectives to guide all human activities within the coastal area, regardless of the sector into which they fall. In other words, in order for all the diverse participants in coastal activities to co-operate harmoniously in the achievement of coastal management objectives they must be singing from the same sheet of music.

The most common obstacle to the introduction of ICM is the absence of a common vision and statement of goals, objectives and agreed means of attaining them, supported by the key stakeholders. Any move from a sectoral approach towards integrated coastal management usually meets with resistance from at least some sectoral agencies. Well-established government departments often dislike the idea of being bound to implement a coastal policy or programme that has been formulated by a consultative process that is not under their direct control. New legislation may be the only effective way of ensuring that different parts of the government co-operate with one another and engage the public in the demanding task of preparing comprehensive coastal management policies, plans and programmes, particularly where none has existed in the past.

Some countries begin with a coastal management initiative that develops a general ICM policy or programme and then enact ICM legislation to ensure that this process is sustained and further developed (e.g. by the formulation of more detailed local or provincial plans). This is usually done by mandating public sector agencies to review and updated the ICM programmes periodically, and to ensure that measures are taken to implement them. 


\subsubsection{Issues to be Considered}

Designing legislation that requires the development of specific coastal management plans, policies or programmes (CMPs) requires the consideration of a range of issues with far-reaching importance. Among other matters it will usually be necessary to consider:

- how to ensure that all relevant stakeholders are involved in the process of developing these CMPs on an on-going basis;

- how to ensure that the CMPs are truly integrated and not merely an amalgamation of different sectoral plans that apply to the coast;

- the precise nature and legal status of these CMPs (e.g. they might merely indicate government policies and planning objectives or they could also be used as development control instruments and influence the granting of authorizations to use coastal resources) ${ }^{212}$;

- who will be obliged to comply with them (i.e. will they be legally binding on both the public and private sectors or will they apply only to publicsector decision-making);

- what relationship these CMPs will have with other plans and programmes (e.g. existing spatial land use management plans and biological diversity plans) and how conflicts between different plans will be resolved.

\subsubsection{Promoting an Integrated, Non-Sectoral Approach to Policy Formulation}

A number of legal techniques have been employed to help to ensure that the coastal policy and programmes that are developed are integrated and nonsectoral in nature. They include:

(a) the use of statements in the preamble to coastal legislation drawing attention to the necessity for integrated policies;

212 Queensland's Coastal Protection and Management Act, 1995 provides that approved coastal management plans at the State and regional level have the status of subordinate legislation (sections 29, 36, and 42) and may deal with any matter that the Act allows to be dealt with by way of regulations under the Act, including making it an offence not to comply with the plan and prescribing penalties (within limits set by the Act). 
(b) requiring the agency responsible for leading the process of formulating the CMP to involve a range of stakeholders or giving the responsibility for formulating the CMP to a body on which stakeholders are represented; and

(c) using legislation to define a common purpose and principles that must be applied when formulating plans that affect coastal areas.

In New Zealand the Resource Management Act, No. 69 of 1991, uses a common purpose and principles to guide both the formulation and implementation of plans that affect coastal areas. The Act states that the purpose of the Act is "to promote the sustainable management of natural and physical resources" and then defines what "sustainable management" means $^{213}$. The overall purpose is then given a more specific focus by providing in the following section that all persons exercising functions and powers under the Act in relation to natural and physical resources must recognize and provide for certain matters of national importance, including:

\footnotetext{
"(a) the preservation of the natural character of the coastal environment (including the coastal marine area), wetlands, and lakes and rivers and their margins, and the protection of them from inappropriate sub-division, use and development: ...

(d) the maintenance and enhancement of public access to and along the coastal marine area, lakes and rivers" 214 ;
}

The Act also specifies other matters which persons exercising functions and powers under the Act must have particular regard to, which include the efficient use and development of natural and physical resources, and the recognition of the intrinsic values of ecosystems $\mathrm{s}^{215}$. The cumulative effect of these provisions is therefore: (i) to establish a common purpose to which all activities conducted under the Act must be directed; (ii) to give an enhanced importance to the conservation of the coast by defining it as an issue of national importance; and (iii) to establish certain principles to guide those exercising powers under the Act.

In Belize the Coastal Zone Management Act No. 5 of 1998 establishes a Coastal Zone Management Authority as an autonomous body corporate, run

213 Resource Management Act, section 5.

214 Ibid., section 6.

215 Ibid., section 7. 
by a Chief Executive Officer (CEO) who is answerable to a Board which includes the Permanent Secretaries of the Ministries responsible for fisheries, forestry, environment and economic development. The CEO must prepare a comprehensive coastal zone management plan and in doing so must "consult with all affected governmental agencies, statutory bodies, non-governmental organizations, and the private sector"216. The Act also provides for the establishment of an Advisory Council on which key public and private sector stakeholders and experts are represented. One of the functions of this Council is to review the Coastal Zone Management Plan ${ }^{217}$.

\subsubsection{Establishing a Duty to Formulate and Review CMPs}

If all relevant public bodies agreed on the need for a comprehensive integrated coastal management programme and were prepared to co-operate fully with one another, it might not be necessary to enact legislation that required the production of such a programme. However, there are a several advantages to enacting a legal instrument that imposes a duty on one or more organs of state to produce a CMP:

1. A clear legal mandate can be useful in persuading recalcitrant public officials to co-operate and in obtaining budgetary allocations.

2. The legislation can specify the minimum content of the programme, the procedure to be adopted in formulating it (including, for example, public participation mechanisms) and how often it must be reviewed.

3. The existence of a legally-mandated CMP makes it easier for the public as communal owners of the coast to hold the state, in its capacity as guardian of the coast, accountable.

4. The legal status of the programme and its relationship with other state policies and programmes can be specified and mechanisms established for resolving conflicts between them, thereby reducing the possibility of uncertainty.

216 Coastal Zone Management Act No. 5 of 1998, section 23.

217 Ibid., section 7(e). 
5. The programme can be used as a tool for development control (e.g. by providing that developments that are contrary to the programme will not be permitted unless specially authorized) which would not generally be possible with non-statutory programmes.

\subsubsection{Achieving Mutually Consistent CMPs}

In countries in which there are extensive coastal areas, it will almost inevitably be necessary to establish coastal plans or programmes at different levels. The level of generality required in setting a national vision, goals and objectives for coastal management, is likely to make a national CMP of limited use at a local level. This means that there will almost always be a need for more detailed local CMPs which elaborate the general prescriptions in the national CMP and can be tailored to fit the diversity of local conditions. As soon as more than one level of plan is required, it is necessary to establish mechanisms for ensuring consistency between them. There are a number of different legal mechanisms that can be used to achieve this. These include:

(a) establishing a common purpose and principles in order to promote the emergence of a consistent, common approach at all levels;

(b) prescribing minimum requirements for CMPs at each levels;

(c) defining the outcomes to be achieved and the process to be followed, rather than the substance of the CMPs; and

(d) providing for a "cascade" of plans whereby lower order CMPs must be consistent with higher order CMPs and are either reviewed or are reviewable to ensure that they are consistent.

In the USA the Federal government has sought to address the issue of consistency by establishing basic minimum requirements for any State CZM programme (see Box 12 above). To some extent this was in response to the constitutional limitations on the power of the Federal government and also to the great physical, economic, political and cultural diversity among the many coastal areas in the USA. Although this flexible approach has been one of the strengths of the US system, it resulted in a number of shortcomings. For example, from a national perspective, there is a lack of a well developed overall national vision, and of substantive national coastal standards. An absence of strong Federal co-ordinating mechanisms to ensure a coherent approach among different states has further entrenched a geographically 
fragmented approach to coastal management based on state boundaries rather than on an ecosystem approach ${ }^{218}$.

In New Zealand the Resource Management Act uses the so-called "cascading approach"219. The RMA requires the Minister of Conservation to prepare at least one national coastal policy statement. Regional councils must prepare regional policy statements and must have at least one regional coastal plan for their coastal marine area (the area between the high water mark and the twelve-mile limit of the territorial sea) and may produce other regional plans too. Territorial authorities must produce district plans. Compatibility is achieved by requiring regional coastal plans to be approved by the Minister of Conservation ${ }^{220}$ and by requiring territorial authorities which are preparing district plans to have regard to regional policy statements and plans and to consider the need for consistency with adjacent district plans ${ }^{221}$. The RMA also states expressly that a regional plan shall not be inconsistent with New Zealand's coastal policy statement ${ }^{222}$.

Constitutional issues may also affect the choice of mechanisms to achieve consistency. For example, in South Africa the Constitution defines national, provincial and local government as separate but inter-related spheres of government rather than tiers of government in which local government is subservient to provincial government which is in turn subservient to national government. Each sphere of government has exclusive legislative and executive authority for certain activities while others are subject to the concurrent authority of more than one sphere of government. This limits the ability of, for example, the national government to dictate to provincial governments on certain issues. Similar limitations are usually also found in federal systems where a federal government may not be constitutionally empowered to require a state to observe certain federal government planning requirements.

218 See Humphrey, Burbridge and Blatch, 2000, p. 280.

219 New Zealand has twelve regions, each of which has a regional council. There are also seventy territorial authorities (district or city councils) and four unitary authorities which combine the functions of regional and territorial authorities. See Gibson, 1999, p. 34.

220 RMA, Schedule 1.

221 RMA, section 74.

222 RMA, section 67(2)(a). 
At a more practical level, an enormous amount of bureaucracy and undesirable delays may be created if lower level plans are required to give effect to higher level plans, and must be reviewed in advance to ensure consistency. This means that each level of plans must be prepared sequentially rather than simultaneously (i.e. a provincial programme cannot be prepared until the national programme is finalized, and similarly local programmes will have to wait for the completion of provincial programmes). Implementation of lower order plans will be further delayed if they are subject to prior review, particularly if they are found to be incompatible with the higher order plan. This would mean that amendments must be made, which will usually have to be subjected to a public participation process.

The rapid deterioration of coasts throughout the world means that it is important to reduce the period of time taken to establish a fully operational ICM system. Accordingly, it may be desirable to consider deeming the first national ICM programme that gave rise to the impetus for legislative reform, to be the first national ICM programme and then to provide for its review in accordance with the newly established legislation, within a defined period.

Another technique that can be used to avoid unnecessary delays is to authorize provincial and local governments to issue their own CMPs consistent with national goals and objectives and to empower the national minister or other appropriate body to review these CMPs for consistency, within a defined period after they are brought into effect. The disadvantage with this approach is that it allows potentially inconsistent plans to be implemented for a while. However the risk of this can be reduced if the national government participates in the public comment procedures on the draft provincial or municipal CMPs. The main advantage of this approach is that it allows the implementation of CMPs to begin much earlier than would be the case if prior authorization was required.

\subsubsection{Nature of Coastal Management Programmes}

Coastal management programmes or plans are sometimes conceived as spatial plans similar to those used in many countries for land-use planning. The legislation of some countries such as France, provides for the planning and zoning of marine areas in a manner that is similar to the terrestrial system. Coastal management professionals on the other hand, tend to understand CMPs as incorporating a variety of components including, 
policies, spatial plans, management objectives, strategies, plans of action and even budgets.

Most ICM legislation to date favours a definition of CMPs that is broader than spatial plans but that does not include matters such as budgets. The Australian State of Queensland's Coastal Protection and Management Act, 1995, prescribes that the State coastal management plan must describe how the coastal zone is to be managed and may include:

(a) a statement of principles and policies by which the coastal zone and its designated areas are to be managed; and

(b) a map or series of maps showing coastal resource information; and

(c) may make provisions concerning anything about which a regulation may be made under the Act, including prescribing offences and penalties for contravening the plan ${ }^{223}$.

The Act also provides for the preparation of regional coastal management plans which in addition to the above, may include more details such as the relationship between public and private infrastructure, a scheme of coastal management works, and the identification of key coastal sites that require special coastal management ${ }^{224}$.

New Zealand's Resource Management Act requires the preparation of a New Zealand coastal policy statement in order to achieve the purposes of the Act in relation to the coastal environment. The Resource Management Act specifies the matters in respect of which the coastal policy statement may establish policies 225 . The national coastal policy statement may include policies in relation to the matters to be included in regional coastal plans with regard to the preservation of the natural character of the coastal environment.

Regional policy statements are intended to achieve the purpose of the Act "by providing an overview of the resource management issues of the region and policies and methods to achieve integrated management of the natural

223 Coastal Protection and Management Act, 1995, section 26.

224 Ibid., section 31.

225 Resource Management Act, section 58. 
and physical resources of the whole region"226. Regional coastal plans must also be prepared but may be incorporated within an overall regional plan ${ }^{227}$.

From a legal perspective it is important to distinguish between those elements of an overall ICM programme that ought to be given a specific legal status in order to function as part of a regulatory regime and other aspects, such as action plans, strategies and budgets which relate to management performance and should not be included in legislation. From a legal perspective, any CMP or part of a CMP that is to be used as part of a regulatory framework established by law should be expressed clearly and with sufficient precision to ensure that it is reasonably easy to determine whether or not it has been complied with. There are many different ways of doing this and well formulated principles, coastal management objectives, standards, rules, or procedures in a CMP can all play important functions in a governance framework for ICM.

One of the key factors to consider is the inter-relationship between CMPs and other planning instruments. These may include:

- broad, large-scale plans to guide the rational development of land (sometimes referred to as "structure plans");

- detailed local zoning scheme that are used primarily as an instrument of development control;

- national economic development plans and programmes (e.g. Indonesia and Thailand)

- integrated economic development plans at the regional or municipal levels which take into account a variety of economic and social factors other than traditional land use management concerns (e.g. the integrated development plans that must be prepared by local authorities in South Africa); and

- sectoral or special purpose planning instruments (e.g. fisheries management plans, catchment management plans for rivers and lakes, and plans relating to the conservation of biological diversity prepared to give effect to the Convention on Biological Diversity).

226 Ibid., section 59.

227 Ibid., section 64. 
The principle of integration inherent in the ICM approach requires that consideration be given to how any ICM programme will relate to these other planning instruments. In many countries, particularly developing countries, the emergence of the concept of sustainable development as an overarching policy goal has made it easier to convince officials of the desirability of an integrated approach to national development planning which incorporates economic, social and environmental concerns. However those designing ICM legislation are often required to decide how to ensure that coastal concerns are integrated into other plans, how to ensure that other government agencies take account of and comply with CMPs, and how to resolve conflicts between CMPs and other plans.

Legal mechanisms that can be used to promote the integration of coastal concerns into planning generally in order to enable coastal management programmes to work effectively in conjunction with other planning instruments include:

- creating a legal duty for persons formulating any form of public policy or plan that is likely to have a significant effect on the coastal environment to take account of CMPs and, where possible, promote the attainment of coastal management objectives;

- imposing a legal duty on any person undertaking a strategic environmental assessment of a government policy, programme or plan, to take account of any existing CMPs, and in particular, the effect, if any, of the policy, programme or plan on the attainment of any coastal management objectives;

- providing rules or procedures for resolving conflicts between CMPs and other plans, e.g. by stipulating that in the event of a conflict between the provisions of a CMP and those contained in general land use plans, the coastal management objectives and restrictions will take precedence within the coastal zone (or a specified part of it) but in other areas the land use plans will take precedence. 


\subsection{Public Participation and the Devolution of Power}

\subsubsection{Achieving Effective Public Participation}

As discussed in section 3.5.8, a variety of international instruments such as the Rio Declaration and Agenda 21, stress the importance of public participation in environmental decision-making. This is also evident in regional instruments such as the European Council Recommendation on the implementation of integrated coastal zone management in Europe (see Box 4). The Recommendation states that coastal zone management in Member States should involve "all the parties concerned (economic and social partners, the organizations representing coastal zone residents, nongovernmental organizations and the business sector) in the management process, for example by means of agreements and based on shared responsibility"228. National ICM programmes also frequently stress the importance of effective public participation (see Annex 3 on the South African experience).

In many cases, a high degree of public participation can be achieved without legislative intervention. However the advantage of enacting legislation that provides for public participation is that it enables the public to hold public bodies and others, such as developers, accountable if the prescribed procedures are not followed.

The degree of public participation provided for in legislation can range widely. Typical examples include provisions: inviting the public to submit comments or objections in relation to a proposed authorization or plan; imposing a positive obligation on developers to solicit the views of interested and affected parties concerning a proposed development; and providing for civil society organizations to be represented on decision-making bodies. In general it can be said that there is a trend towards providing for increased public participation in environmental decision-making. This right is usually supported by ancillary rights such as a right of access to information and improved access to justice (e.g. by making it easier for members of the public

228 Recommendation of the European Parliament and of the Council of 30 May 2002 concerning the implementation of integrated coastal zone management in Europe, Chapter II, para. (f) (2002/413/EC Official Journal No. L148, 24 June 2002). 
to bring civil actions to enforce compliance with legislation). In some cases this trend is partially driven by international or regional treaties. In Europe for example, the Aarhus Convention has prompted a review of public participation procedures in various countries.

The key challenge in many countries is to provide for public participation (particularly by those affected by the proposed measures) that is effective. For example, a legislative provision that stipulates that members of the public may appeal against an administrative decision within a certain period, will be ineffectual unless the legislation also provides a mechanism whereby potential objectors are informed, firstly, that the proposal is under consideration, and secondly, that a decision has been made and the reasons for it.

Special attention should also be paid to ensuring the participation of poor or otherwise marginalized people who may be heavily dependent on the use of coastal resources. Commonly used provisions to ensure public participation, such as requirements for advertisements in newspapers or the submission of written comments, may be ineffective in securing their participation. Therefore it is advisable to impose an obligation on public bodies to ensure that they employ methods that are likely to be effective (e.g. by holding public meetings in the areas concerned and recording the views expressed at these meetings).

\subsubsection{Devolution}

In some cases the issue of public participation is coupled with a commitment to devolve responsibility for coastal management to the lowest administrative level at which it can effectively be carried out. For example, the European Union applies the principle of subsidiarity, which requires powers to be devolved to the lowest level at which they can be exercised effectively.

A similar international trend is evident in fields of nature conservation and coastal fisheries management ${ }^{229}$. In both areas there is a growing recognition that "co-management" regimes are often more appropriate and effective than

229 See for example Meinzen-Dick et al., 2001; Pomeroy et al., 2001; Juntarashate, 2004. 
centralized, "top-down" management regimes ${ }^{230}$. Co-management regimes involve management authority and responsibilities being shared between public agencies and the people who are the main users of the resource, and sometimes with other recognized stakeholders. Giving the people with the most intimate relationship with the wildlife or fisheries more secure, longerterm use rights to harvest them is an important part of securing their commitment to playing a pro-active role in conserving the wild species and in ensuring sustainable levels of use.

\section{The legal recognition of communities and user groups}

Reluctance by government officials to transfer powers previously held exclusively by the public sector to communities or the private sector, is common. However, even if the government is willing to devolve powers and enter into co-management relations, there are frequently legal obstacles to doing so. For example, in many legal systems communities or groups of users are not legally recognized as having an independent legal status. This means they are effectively invisible from a legal perspective. As such, contracts can only be entered into, and rights and responsibilities delegated to, individuals within those communities or groups. Even if there is an understanding that rights are being granted to an individual as a representative of a community, because this is not reflected in the legal relationships it can be extremely difficult to enforce this understanding if the individual concerned acts irresponsibly or in a self-interested manner ${ }^{231}$.

In some cases formal arrangements between the state and a chief or other person representing a traditional community are effective even though the community as a whole is not constituted as a legal entity. This is only likely

230 In fact collaborative or co-management regimes have often been initiated in response to the dramatic failure of traditional systems. See for example, Sen, S. and Raakjær Nielsen, J. 1996.

231 For example, in South Africa fishing licences and quotas for small-scale commercial fishing were issued to the skippers of small fishing craft on the understanding that the benefits would be shared on a pre-agreed basis between the whole crew and the fishers union. Some skippers then decided to move areas taking the quota with them, and another skipper was caught fishing illegally which meant that the quota could be cancelled. In both situations the other crew members found themselves in a particularly vulnerable position. 
to be successful where one is dealing with a community that is cohesive and organized on the basis of customary laws and practices that are relatively intact. However, in many cases, the community is not clearly defined. It may be unclear, for example, whether someone who originates from the area in question but currently resides elsewhere, is entitled to participate as a full member of the community. Furthermore, the ways in which decisions within that community are made may no longer be acceptable to all concerned, and there may be a danger of benefits arising from any co-management arrangement being "captured" by a sector within the community. In such circumstances, legislative intervention may be required to create a new form of legal entity that can be used by groups of people with a common interest in using a specific coastal resource. Legislation of this nature can be an important part of empowering local communities by creating opportunities for user groups to establish themselves as a legal person with which the state can enter into contracts or to which it can devolve powers.

In South Africa, the issue of granting legal recognition to groups of people who no longer lived as traditional communities came to the fore in the context of restoring land to people who had been unjustly dispossessed of it during apartheid. In many cases, the people who had once formed a community were geographically scattered and decision-making structures no longer existed. This meant that there was no community to restore the land to. The government responded by enacting the Communal Property Association Act, 23 of 1996, which allowed a group of people who had a common claim to land restitution to form themselves into a legally recognized association. In order to be registered as a communal property association, a group is required to follow democratic procedures (monitored by state officials) and to adopt a constitution that meets certain prescribed conditions. The procedures and minimum requirements for the constitutions are designed to ensure that these associations are democratically constituted and have in-built checks and balances to prevent abuses of power by the members.

This approach was subsequently adapted by the drafters of the Coastal Zone Management Bill which provided for the establishment of coastal community associations. The Bill232 allows for persons with a common interest in using a particular portion of the coast to constitute themselves

232 The Bill has not yet been released to the public. 
into democratically organized entities, which could apply to be registered as legal entities by the government. Once recognized and registered, they may enter into co-management or other agreements and have coastal management powers delegated to them.

When establishing co-management arrangements in coastal areas it is important to give considerable attention to a range of legal issues in order to avoid practical obstacles to implementation emerging later. It is wise to give consideration at the outset to whether or not there are legislative restrictions on the delegation of powers by public entities or officials to private sector organizations or communities that may prevent the devolution of management authority and responsibility. For example, there are often restrictions on who may exercise powers of investigation and enforcement (particularly powers of entry, search and seizure) which may make it difficult to delegate enforcement powers.

The financing of co-management initiatives also merits careful consideration. For example, legislation dealing with public finances may impose conditions in relation to the use of public funds that may be too onerous for communities or user groups. Furthermore, entities that are not part of the government may be prohibited from imposing application fees or other charges for access to coastal resources unless authorized to do so by legislation, or may be required to pay all such monies into state coffers. Addressing these issues may be critical to the success and sustainability of co-management arrangements and the devolution of management authority and responsibility.

\section{Facilitating diverse management approaches}

It is important to recognize not only that coastal areas are different from purely terrestrial or purely marine areas, but also that there is a great deal of diversity within coastal areas. Coastal ecosystems are typically very diverse and may be used for many different purposes. This means that different coastal areas may need different management approaches to accommodate the special characteristics of the area or to achieve a particular purpose. For example, in one area users of a large estuary that falls partially within several different municipalities may wish to establish institutional arrangements that will enable holistic management of the use of the estuary as a whole. In another area, a specific management regime may be required to enable a municipality, in partnership with government and private entrepreneurs, to 
initiate a major waterfront development in an urban area. No single model is likely to be appropriate to both situations.

One way of responding to the diversity of management requirements, is to provide for the establishment of new bodies that can be given responsibility for addressing particular issues (e.g. the regeneration of an urban coastal environment or the restoration of a degraded section of coastline) within a defined area. This can be done, for example, by making provision for areas to be declared special management areas within which a specially constituted authority or agency has defined powers to achieve certain objectives. It is important to note that such provisions are non-prescriptive, in the sense that there is no obligation to establish special management areas or agencies, but are enabling in the sense that they create opportunities for site-specific forms of coastal management based on co-operation among interested parties. "Enabling" legislative provisions such as these can be used to create a legal environment within which diverse forms of coastal management can flourish.

Another approach is to provide for certain coastal areas to be singled out for special attention (see also section 8.7 on protected areas). An example is the Coastal Protection and Management Act, 1995 of the Australian State of Queensland. The Act provides for areas that require special development controls and management practices to be declared to be "coastal management districts"233. Districts may be declared in regional coastal management plans or by the Minister, but may only be declared in respect of number of factors 234 , and after following a public participation process ${ }^{235}$.

233 Coastal Protection and Management Act, 1995, Chapter 2, Part 3, sections 54-58A.

234 Ibid., section 56. This section sets out seven considerations namely: (a) the area's vulnerability to erosion by sea or wind; (b) whether the area should be kept in an undeveloped state to maintain or enhance the coast or coastal resources; (c) public access; (d) foreseeable human impact and natural hazards; (e) existing interests in, and rights to land and area; (f) aboriginal tradition and the customs of aboriginal and Torres Straite Islander people; and (g) planning and development management of the area.

235 Ibid., section 57. 


\subsection{Information Management}

\subsubsection{Why Information Management is Important}

It is important to consider the role of information and new information technologies from a legal perspective because: (a) legislative amendments may be needed before the information from new technologies can be used to full effect; (b) the gathering and dissemination of information can have a significant impact on compliance levels by reducing compliance costs; and (c) information is necessary to review and improve coastal governance systems.

The role of information in ICM is fundamental and is assuming greater importance as new technologies enable us to gather new information and to process and communicate information more easily. A well-functioning ICM system requires a constant flow of information. Initially, to identify, understand and prioritizie the most important issues, then to formulate environmental quality objectives and standards or sustainability indicators against which the performance of the ICM programme can be measured. Once the ICM programme is functioning, monitoring mechanisms are necessary to gather information concerning both how the management system itself is functioning, and on the state of the coastal environment to determine the effect, if any, which the management measures are having. This information must then be analyzed and fed back into the ICM programme so that it can be adjusted.

The communication of information is also vital to maintain the involvement of private sector participants in coastal management and to enhance their capacity to play a meaningful role. In many countries there has been a great increase in the public availability of information about the state of the coastal environment and the coastal management measures being taken. This trend has been driven to a large extent by introduction of the internet and e-mail, supported in some countries by legislation giving the public greater rights to obtain access to information, particularly in relation to the environment. Although this is an extremely positive step, it must be recognized that providing information via the internet still does not reach a very large proportion of coastal users, notably poor or marginalized communities. It is therefore essential that the new digital forms of communication are not seen as substitutes for other forms of communication. 


\subsubsection{Impacts on Legislation}

The management of information in the context of ICM can give rise to a number of legal issues that may require consideration during the legislative reform process. Firstly, legislative changes may be necessary to enable or facilitate the exchange of information. There may be legal provisions or longstanding administrative practices of official secrecy that obstruct the free flow of information from government sources, or even between government ministries.

On the other hand, changes to legislation or to the conditions of licences or other authorizations may be required in order to impose a duty on coastal users to provide the necessary data concerning their use of the coast. In some cases the private sector may be reluctant to contribute valuable information to a public database because of concerns about the confidentiality of data. In these circumstances it may be important to provide legislative protection for confidential information. At a more practical level, it may also be necessary to amend a variety of official forms (e.g. licence application forms or fish landing receipts) to make it easier for the requisite information to be captured electronically. This may entail amendments to legislation that prescribes the forms.

In many cases, new technologies have created opportunities for new regulatory approaches but have also created the need for legislative amendments. Perhaps the most striking example is the development of vessel monitoring systems (VMS) which enable the activities of a distant fishing vessel to be monitored by satellite by a land-based station. These technologies have greatly enhanced the monitoring, control and surveillance capabilities of coastal states but it has sometimes proved difficult to use the information obtained to secure convictions. For example, the courts in several common law countries have refused to accept the reliability of data from new technologies unless it is supported by the evidence of experts who can explain exactly how the technology works and confirm that there was no possibility of data being corrupted or tampered with at any stage in the process. This greatly reduced the practical value of this information since the expense and inconvenience of involving senior fisheries personnel and VMS experts in court cases potentially outweighed the benefits of securing a conviction in all but the most important cases. Several countries have responded by introducing legislative amendments that empower the courts to regard a particular new technology as reliable in the absence of evidence to the contrary. The evidentiary burden on the state can also be reduced by 
legislative provisions that allow technical evidence (e.g. regarding the readings obtained from the equipment) to be given by way of written certificates submitted to the court.

\subsubsection{Impacts on Compliance}

Not all new technologies require legislative amendments before they can be used effectively in regulatory regimes. For example, geographic information systems (GIS) create new opportunities for communicating important coastal information to coastal users in a manner that has the potential to increase compliance with the law and to reduce the risk of non-compliance. A GIS can represent complex layers of information in easily understandable, spatial forms such as multi-layered maps. This means that it can be used to make information about the distribution ranges of various species and the location of areas of high ecological value to the public. If this information is easily accessible, potential developers can identify and avoid these areas, and thereby reduce the risk of not obtaining the necessary authorizations. If this information is not easily available, a developer may incur significant expenditure in acquiring land rights, and preparing plans before discovering that the proposed development would affect an ecologically sensitive area and therefore may not be permitted to proceed. In such circumstance developers often lobby the authorities to authorize the development anyway, which may give rise to further difficulties.

\subsubsection{Refining Coastal Governance Systems}

Feedback regarding the functioning of ICM legislation is important to enable the governance system (including the legislation) to be further refined and improved. For example, if municipalities are responsible for reviewing EIAs and authorizing certain coastal projects, it is important to assess whether or not the law is being applied consistently by different municipalities. It is also important to evaluate how effective the law is in achieving ICM policy objective such as preventing ecological damage by infrastructural developments. Without this information the law may be applied very differently in different areas, and deficiencies in the system (e.g. projects being authorized subject to inappropriate conditions) may not become apparent until significant damage has occurred.

Unfortunately, it is relatively unusual for data relating to the effectiveness of a particular law to be systematically gathered and analyzed. Information 
concerning the degree to which new legislation has changed the behaviour of coastal users is also extremely useful but difficult to obtain, due in part to the many factors which can influence compliance (see section 11.2). However, in broad terms, when an undesirable activity is prohibited, one would expect to see the number of prosecutions escalate as the most flagrant violators of the law are targeted. This should be followed by an increase in the percentage of prosecutions that are successful (as expertise among the enforcement officers and prosecutorial staff improves). The upward trend in successful prosecutions would typically continue for a period before peaking and dropping as compliance increases in the face of an increased risk of being successfully prosecuted.

Although it may be difficult to assess the effectiveness of new legislative provisions with a high degree of accuracy, it is very important that careful thought is given as to how this might be done. Not only is this consistent with the iterative approach inherent in ICM (which, like natural systems, relies on feedback loops of information to learn from experience and respond appropriately), but it is also necessary for the rational development of a regulatory framework.

Gathering information on the socio-economic and ecological impacts of new legislation can also be important in building public and political support for the law, and hence compliance (see section 11.3.1). For example, the introduction in 2002 of regulations that prohibited the recreational use of vehicles on South African beaches except in designated areas was greeted with outrage by recreational fishermen and others who had become accustomed to using four wheel drive vehicles on beaches. At least two court applications challenging the legal validity of the regulations were made (unsuccessfully), and it was alleged that the regulations were adversely affecting property values, were unfairly affecting the businesses of vehicle dealerships and were impoverishing poor coastal communities who provided services to recreational fishermen in remote areas. However public support for the regulations is increasing as the benefits become more apparent. These include a dramatic reduction in the mortality rates of black oyster catcher chicks (a rare bird species that nest on beach sands) and the emergence of new employment opportunities as poor coastal communities provide bearers to carry fishermen's equipment to remote beach areas and guard their vehicles. 


\subsection{Funding}

The provision of funds to support activities that are consistent with national, state, provincial or local ICM programmes is potentially an extremely powerful method of achieving ICM objectives. The provision of incentives encourages stakeholders to collaborate and enter into partnerships to achieve specified ICM objectives. Providing financial assistance also goes beyond improving compliance and encourages and enables the development of new initiatives that are consistent with ICM policy objectives. Using financial incentives is usually far more effective than the command and control approach, which relies on using sanctions to enforce a hierarchical approach. However this approach does require an on-going ability to provide or generate the funds necessary to provide incentives.

The best-known example is the CZMA in the United States which provides for Federal funds to be granted to states for the development and implementation of Federally approved coastal zone management programmes (see Box 12). Interestingly, amendments introduced to the CZMA in 1990 required state coastal zone management programmes to meet new requirement but also provided for states which failed to submit programmes that met the new requirements to be penalized by reductions in their grants 236 .

In many countries, the key issue is deciding where the money to fund ICM compatible projects will come from. The initial response from public bodies is sometimes to reject the establishment of dedicated funding mechanisms to support ICM on the basis that the government does not have additional funds to dedicate to coastal management. However, it should be borne in mind that coastal areas typically generate very significant benefits for the economy but these are often not visible because of the way that official data

236 Participating states were required to prepare coastal non-point pollution control programmes and establish a new scheme for voluntary enhancements to state programmes to meet objectives in one or more of eight areas, namely: coastal wetlands management and protection; natural hazards management, including the potential for sea level rise; public access improvement; reduction of marine debris, assessment of accumulative and secondary impacts of coastal development; special area management planning, ocean resource planning; and siting of coastal energy and government facilities. 
is collected and analyzed (see section 1.5.1). This means that in most cases there are existing revenue streams from which funds for coastal management could be diverted (e.g. royalties from offshore mining, licence fees from fishing, and rentals from leases of portions of the foreshore or sea).

Proposals to channel a proportion of this revenue into a dedicated coastal fund may be resisted from several quarters. Coastal stakeholders from a particular sector (e.g. commercial fishing) may object to revenues derived from their activities being diverted to support other coastal activities. State agencies (e.g. those responsible for mining) may object to a proportion of the revenues which they previous received or were credited with having generated, being diverted elsewhere. Ministries responsible for government finances often resist the creation of separate funds as a matter of principle since this reduces their ability to cross-subsidize in the national budget. Other concerns may centre on who makes the decisions regarding how the money in such a coastal fund will be dispersed. For example, municipalities or provincial governments may be reluctant to agree to revenue that previously accrued to them being paid into a coastal fund unless they have a role in deciding how the funds will be allocated. In some cases, the national government may be concerned about increased risk of corruption if significant amounts of public funds are not being directly administered by a government department but by another institution such as a trust fund or statutory body.

Despite the potential for opposition to establishment of a coastal fund, in many cases it will be worth pursuing because of its power as a mechanism to promote an integrated approach to coastal management through:

- establishing a single, multi-sectoral body for making funding decisions;

- deciding what to fund on the basis of consistent, integrated criteria (i.e. consistency with the ICM policy goals and principles);

- making the contribution of the coast to the economy more visible and thereby enhancing arguments for its protection;

- determining coastal priorities on a holistic basis (e.g. the best way of improving coastal fisheries may be to spend some of the revenue derived from fisheries in protecting and enhancing a coastal estuarine system in which marine fish breed);

- building a co-operative approach to coastal governance among public and private sector stakeholders; 
- creating mutually supporting financial disincentives and incentives to multiply the impact on behaviour (e.g. by simultaneously increasing levies on resource users to discourage excessive consumption, and then spending the revenues on protecting or enhancing the coastal environment from which the resources were taken); and

- promoting and supporting the development of diverse and innovative approaches to coastal management (as opposed to merely prohibiting or discouraging undesirable activities).

In countries where the coast is defined as public property or has some special status as a public commons, the rationale for establishing a dedicated coastal fund is stronger. The unique legal status of the coast means that it is appropriate that revenues derived from granting certain exclusive rights to use this public "asset" (e.g. rentals from leases of the foreshore) ought to be used to fund the protection, maintenance or restoration of the coast. 


\section{TECHNIQUES FOR PRESERVING THE INTEGRITY AND PUBLIC CHARACTER OF THE COAST}

\subsection{Introduction}

The coast has been given a special legal status in many different legal systems for thousands of years. As discussed in section 2.3.1, Roman law classified the sea and sea-shore as the common property of all (res omnium communes) which meant that these areas could be enjoyed by all and could not be appropriated for private use. Interestingly, the Romans believed that this status was derived from natural law rather than being a concept which they themselves had developed.

In Scandinavian countries such as Finland, Norway and Sweden, the traditional privileges of the public to use the sea-shore and undeveloped areas for recreation and to use coastal waters for boating and swimming, has survived in the form of non-statutory rights referred to as "Everyman's rights" (see Box 14). Other customary law traditions were not property based and understood humans as being dependent on the environment of which they form part rather than owning it. However, one of the common characteristics of most legal systems is the legal recognition of the right of citizens to have access to the sea-shore, and to use it for certain traditional purposes such as swimming, fishing and mooring boats or drawing them up on the beaches.

\section{Box 14}

\section{EVERYMAN'S RIGHT}

In Norway, "Everyman's Right" gives the public the right to walk, bathe, fish and land boats anywhere along the coast except in built-up or cultivated areas or where the law specifically prohibits it (e.g. within nature reserves and military zones). In Sweden, Everyman's Right entitles persons to cross private land in the countryside (except private plots around dwelling houses), to fish with a rod or hand tackle along the coast (except for salmon fishing in one area), to navigate, to swim and to moor a boat temporarily and go ashore anywhere except close to dwellings or where entry has been specifically prohibited.

The rights afforded by this principle under Finnish law are similar, although fishing rights are limited. However, more significantly, the Everyman's Rights in Finland are subject to a reciprocal obligation not to harm the natural environment. This is recognized in the Constitution of Finland which provides in 
section 14(a) that:

"(1) Everyone shall be responsible for the natural world and for its diversity, for the environment and for the cultural heritage;

(2) Public authorities shall strive to ensure for everyone the right to a healthy environment as well as the opportunity to influence decisionmaking concerning his living environment."

(Source: Gibson, 1999.)

In most countries, the original special legal status of the coast has been modified over time by legislation. Usually rights of access have been restricted (e.g. within developed areas of the coast, or to defence installations), and rights to use coastal resources have been limited in the face of increasing pressure on the coast (e.g. permits are almost universally required in order to undertake commercial fishing). Despite this, in most cases the core idea that the coast has a special legal status as a public commons has survived in law. In most legal systems the inter-tidal zone (foreshore) and immediately adjacent coastal waters retain a special status as an area available for public use which may not be appropriated for the exclusive use of private or state interests except in exceptional circumstances.

This, together with the fact that many ICM programmes will identify as one of their principal goals, the preservation or conservation of the coast for the benefit of present and future generations, gives rise to a number of important considerations to be borne in mind in developing ICM law. Drafters of ICM legislation will frequently have to answer the following questions.

- Should the special legal status of the coast and in particular the public rights to use it, be strengthened or changed in any way?

- Who should be responsible for playing the role of custodian in relation to this area of public commons?

- Should certain groups in society - such as poor, coast-dependent communities - be given preferential use rights to the coast in order to achieve socio-economic objectives?

- Are special legal measures justified to protect the natural environment in coastal areas for the benefit of future generations? 


\subsection{Strengthening the Legal Status of the Coast as a Public Commons}

It is important at the outset of any ICM legal reform process to be clear about the legal status of the coast. This is often a surprisingly complex task since the original legal status of the coast has often been changed over long periods of time often in an unplanned and haphazard way. This can happen in a variety of ways including, changes in customary use patterns; administrative or court decisions; the sale of portions of the coast, or direct legislative intervention. Physical changes to the coast, such as land reclamation or the construction of artificial islands, can also create uncertainty at to the legal status of particular coastal areas. In these situations one of the most important functions that new ICM legislation can perform is to define clearly the legal status of different coast areas and to restore or enhance the original status of the foreshore and sea as a form of public commons.

For example, one of the main ways in which the Spanish Shores Act of 1988 addressed the problem of private sector encroachment on the sea-shore and inappropriate developments, was to use legislation to reassert customary legal principles. These principles including the concept of coastal public property, and rights of public access both to get to the foreshore and to move along it (see the discussion in section 2.3.1). A similar process is under consideration in South Africa (see Box 15). 


\section{Box 15}

\section{THE LEgAL STATUS OF THE COAST IN SOUTH AFRICA}

In South Africa the original Roman law status of the coast is res omnium communes. This had been modified during the Roman Dutch period which reclassified it as an area that was owned by the state for the benefit of the people (res publicae). This common law concept was later codified in the Sea-shore Act, 21 of 1935, which vested ownership of the sea and sea-shore (as defined) in the head of state and prohibited their alienation. The public's rights in relation to the sea-shore were further clarified and defined by court decision both before and after the enactment of the Sea-shore Act ${ }^{237}$. During the apartheid era, courts even condoned the racial segregation of beaches on the basis that the doctrine of Parliamentary sovereignty meant that the racially discriminatory Acts that authorized the segregation were valid and must be upheld by the courts.

From a coastal management perspective, the issue was further complicated by the existence in some parts of the country of strips of land immediately inland of the high water mark that were designated as "admiralty reserve". This had its origins in the practices of the British Colonial Government and was not a concept familiar to the Roman Dutch legal tradition from which the fundamental status of the coast was derived. Over time, the exact legal status of admiralty reserve land had become unclear. In some areas it appeared that the intention had been to retain state ownership of these areas, for defence or other purposes, whereas elsewhere in the country title deeds to private land indicated that areas of that land had been reserved as admiralty reserve, or in some cases, forest reserve. In these cases, it appeared that the intention was to simply impose building or other restrictions on the use of the designated portions.

In several areas, the absence of legal clarity had been exploited by private landowners to build virtually to the edge of the high water mark. The draft South African Coastal Management Bill seeks to address these issues in several ways. Firstly by restoring the sea-shore itself and coastal waters to their original status as the common property of all (res omnium communes). Secondly, by consolidating areas of admiralty reserve that are in state ownership with the foreshore areas so that they have the same legal status and by incorporating admiralty reserve areas that are in private hands, into a buffer zone within which building and other restrictions apply.

237 For example, in the case of Consolidated Diamond Mines of SWA (Limited) $v$ Administrator South West Africa 1958(4) SA 572(A) the highest Court interpreted the rights of the public under the Sea-shore Act in the light of the historical legal status of the sea-shore and held that "the public have certain simple rights to the foreshore such as to go onto it, to bathe, to fish, to dry nets, to draw up boats ... (and) any substantial interference with these rights would be a wrongful act". 
Reasserting the legal status of coastal lands as public coastal property can often provide a more effective safeguard than merely imposing restrictions on the use of the area in question. For example, in 1997 the Spanish Ministry of Defence sold 22,000 $\mathrm{m}^{2}$ of protected coastal land in Galicia for private development in contravention of the 1988 Shores Act (Ley de Costas). When this was discovered, the Director of Coasts was able to reclaim the land for the public domain on payment of compensation to the purchaser238.

\subsection{Extending the Coast}

In many countries, coastal management is focussed primarily on the management of a core area where the land and sea meet (i.e. the inter-tidal area, sometimes referred to as the foreshore or seashore), and the adjacent inshore waters of the sea. The inland boundary of the seashore is often defined as the high water mark. This means that in areas where the land slopes relatively gently into the sea or a tidal river, the seashore may be fairly wide, but it will be extremely narrow in other areas, for example, where there are sea cliffs. As a result, the degree of protection afforded to coastal ecosystems by giving a special legal status to the seashore, will often vary widely along the coast. This problem may be addressed to some extent by providing for the establishment of buffer zones that extend inland from the foreshore for a defined distance (see section 9.2.3). However a buffer zone of a defined width may be adequate in some areas but will be inadequate in others.

These problems stem from the fact that the inter-tidal areas are part of larger ecosystems and maintaining the integrity of the seashore usually depends on protecting the whole ecosystem, including areas inland of the seashore. For example, the existence of a beach may depend on protecting nearby sand dunes that supply sand to the beach. One of the difficulties inherent in drafting ICM legislation is that legal definitions of coastal areas such as the seashore or buffer zones are of necessity, general in nature and may not be appropriate for all areas of the coast. One way of addressing this is to prescribe procedures that can be followed to adjust the width of buffer zones to take account of local circumstances. However adjusting the boundaries of the seashore itself is often more difficult because this means changing who owns the area (which may require expropriation), whereas buffer zones usually only restrict the uses that can be made of the land.

238 El Pais, 16 November 1998, quoted by Gibson, 1999, p. 83. 
Another approach is to recognize that in some areas it will be appropriate to extend the core coastal area permanently in order to include ecosystems that are integral to the proper functioning of the coastal ecosystem, and so merit the same treatment at the seashore itself. In order to do so it is important for ICM legislation to provide a mechanism for consolidating other areas with the core coastal area so that they also fall under the legal regime that applies to the seashore itself. Including such a mechanism in coastal legislation is particularly important in circumstances in which portions of the foreshore have been lawfully alienated in the past and thereby excluded from the public domain. If these areas are to be re-incorporated into the public domain, they will almost invariably need to be expropriated and compensation paid (since the process involves depriving private owners of their rights and transferring those rights to the public at large). Once expropriated, the legal procedure used for incorporating additional land into the coastal commons can be used.

The practical value of expropriation as a mechanism for consolidating coastal areas into ecologically viable areas of public commons is limited by the availability of public funds to be used to compensate former owners. However, in many countries the state itself may have large land holdings along the coast, particularly areas that are, or were previously, considered unsuitable for agriculture, such as mangrove swamps or dune systems. The extent of these holdings may not be immediately apparent as responsibility for their management may be divided among many organs of government and it is not uncommon to find that, for example, departments of transport or defence have large, ecologically valuable areas of coastal land under their control. One of the most effective means of increasing the area of the coastal commons may be to mandate the preparation of an inventory of state land holdings along the coast and then to identify any coastal land forms that should be treated as part of the public domain. Once identified and demarcated, the legal status of these areas could be changed from state ownership to the public domain. It is usually necessary, or at least desirable, to use legislation to define a clear procedure for doing so. Permanently incorporating in the public domain the coastal lands and waters that form an essential part of coastal ecosystems is also consistent with the ecosystem approach as well as the protection of the rights of future generations. 
In France a similar effect has been achieved through the establishment in 1975 of the Conservatoire $d u$ littoral39. The Conservatoire is a public administrative body that was established to protect outstanding natural areas of coast and lake shores, and stretches of water of at least 1,000 hectares in extent. These areas are protected by the Conservatoire's acquiring ownership of the property (by private purchase agreement, the exercise of the right of preemption or by compulsory expropriation), and once owned the land may not be alienated. Management is often entrusted to local authorities or other bodies and public access is permitted subject to the conservation needs of the site. By June 1998 the Conservatoire had acquired at least 750 kilometres of shoreline 240 .

\subsection{Custodianship of the Coast}

In recent decades, many concerned with environmental management, particularly fisheries, have been strongly opposed to common property regimes which were seen as leading inexorably to the over-exploitation of resources. This understanding has been particularly influenced by Garrett Hardin's seminal article "The tragedy of the commons"241. In that article Hardin attributed the ongoing over-exploitation of fish stocks in international waters to the fact that they were global commons and that every nation had incentive to appropriate as much as possible of the commons to themselves. In fact, the crucial issue in determining whether or not a particular aspect of the environment will be overexploited is how access to it, and use of it, is controlled, and not the nature of the ownership regime (e.g. common property, private property or state property). If access and use rights to any aspect of the environment are not regulated, it becomes in economic terms an "open-access resource" regardless of the ownership regime, and is likely to be over-exploited.

This means that it is essential that a custodian is appointed with the necessary legal authority, powers and resources to regulate access to, and use of the coastal environment, effectively. The role of custodian should also

239 This was established by Loi $n^{\circ} 75-602 d u 10$ Juillet 1975 portant Création $d u$ Conservatoire de l'espace littoral et des rivages lacustres (Journal Officel, 11 July 1975), now consolidated in the rural code (Code Rural, articles L243 and R243).

240 Gibson, 1999, p. 8.

241 Hardin, G. 1968. The Tragedy of the Commons. Science, 162, pp. 1243-1248. 
encompass championing the interests of the coast itself. ICM is based on the belief that the coast should be treated as system and this is also inherent in the ecosystem approach. The custodian must therefore take responsibility for ensuring that the interest of the coast as a whole takes precedence over sectoral interests, and in particular that the ecological integrity of coastal ecosystems are preserved and enhanced.

The state as a whole may be designated as the custodian of the coast on behalf of the public, but different organs of state may share the role of custodian. However it is essential that the state's general obligation to act as a custodian is translated into specific responsibilities of identified organs of state, or other publicly accountable parties. If this is not done there is a danger that the role will not be fulfilled adequately. Indeed, the continuing deterioration of much of the world's coastlines suggests that far greater attention ought to be given to defining and allocating responsibilities and duties to maintain the environmental quality of the coast.

The widespread failure of current management regimes to prevent the ongoing deterioration of coastal areas has prompted governments to consider devolving management responsibility and authority to local user groups (see the discussion in section 7.4.2 above) and giving greater recognition to the customary management practices of coastal communities. Sharing these responsibilities with communities and users usually also involves sharing some of the responsibility and authority for functioning as a coastal custodian. This means that it is even more important to define clearly the roles of all the parties.

In order to ensure that the vital role of coastal custodian is properly defined and allocated, it is important:

- to define who has ultimate responsibility as the overall custodian of the nations coast (usually a particular government, department organ of state);

- to stipulate the key implications of playing that role (e.g. ensuring that the state of the coastal environment is monitored and state of the coasts reports prepared on a regular basis, reporting on progress towards attaining the vision for the coast);

- to allocate the responsibilities for carrying out the necessary complementary functions (e.g. monitoring and enforcement) and to ensure that there are effective mechanisms to hold those responsible for performing these functions publicly accountable; 
- to define the responsibilities of the public (see section 8.5 below);

- to provide legal mechanisms which allow for the delegation of powers to communities or other user groups;

- to define the rights of communities or bodies to whom regulatory powers have been delegated to restrict or exclude the rights of the general public to use a particular area of coast.

\subsection{Creating a Duty of Care in Relation to the Coast}

In general, ancient cultures and systems of customary law appear to have been very conscious of the reciprocal relationship between humans and their environment, and in particular of the importance of respecting the environment on which people depended. The sense that humans have responsibilities or owe duties to nature has in most countries been lost or eroded over time and the primary emphasis tends to be on the rights of the public to use the coast. As human pressures on the coast have increased and demand for resources have exceeded the environment's capacity to supply them on a sustainable basis, these rights have tended to be restricted by legislation. However, in relatively few cases has the public's right to use the environment been balanced by corresponding personal duties to conserve it.

It is becoming increasingly clear throughout the world that the public, and in particular, those who are regular users of the coast, must play an active role in conserving the coast if coastal degradation is to be stopped and reversed. Public authorities are unlikely ever to have sufficient resources to effectively enforce coastal legislation throughout extensive terrestrial and marine coastal areas without the active co-operation and support of the public. In any event, it is both legally and practically appropriate for public use rights in relation to the coastal environment to be balanced by reciprocal obligations to protect the environment.

In some countries such as Finland the idea that the public has certain responsibilities in relation to nature and the coastal environment has survived (see Box 14). However in many countries, the sense that the public has any duty to other coastal users, to future generations, or to the coast itself, has been lost and legislative intervention is likely to be required to reintroduce a "duty of care" in relation to the environment in general or to the coastal environment in particular (e.g. Sweden's Environmental Code, see Box 13). The exact nature of such a duty may be difficult to define with 
precision, and consequently difficult to enforce in some situations. However, this alone should not deter legislative reformers from adopting the concept since such provisions can play an important educative role in changing public attitudes towards the use of the coastal environment and frequently provide a catalyst for the development of more precise social and legal norms.

\subsection{Equitable Access to Coastal Opportunities and Benefits}

The principle that coastal areas should be available for public use and enjoyment is well established in many legal systems. Obviously the coast is not used equally by everyone. This does not create any difficulties when the coastal environment can satisfy the total public demand for use of coastal areas without sustaining long term damage. However as soon as restrictions on public use have to be made to prevent over-use of coastal areas, it is necessary to determine which users should be preferred over others. The issue becomes even more acute in countries in which there are significant numbers of poor or otherwise disadvantaged people, who rely heavily on the coastal environment for their livelihood. In such circumstances, the state may wish to use natural resources over which it has control as a means as addressing socio-political objectives such as poverty alleviation.

In short, excess demand creates a need for public bodies with custodianship responsibilities in respect of the coast to determine criteria to ensure that use rights are allocated fairly and equitably. "Equity" and "fairness" are subjective concepts that should not be confused with equality (i.e. equal access). In some cases the government may decide that it is more equitable to treat different classes of people differently. For example, a state may decide to prefer subsistence fishers over commercial fishers, or people near the coast over those who reside far inland. One of the goals of the South African coastal policy is to ensure that the public has the right of equitable access to the opportunities and benefits of the coast. In order to give effect to this goal, the draft Coastal Zone Management Bill establishes a coastal management principle that requires that priority be given to disadvantaged and coast-dependant communities and individuals. This means that once the Bill becomes law, all public bodies exercising powers in relation to the coast (e.g. to prepare and implementing CMPs, and in granting permits to use coastal resources) will be required to give effect to this principle. This will have the effect of preferring these groups. 
If one social group is given preferential rights to benefit from the coastal commons it is likely to give rise to opposition from other groups who are, by implication, disadvantaged. For this reason, it is important that decisionmaking processes are transparent and that as far as possible, objective criteria are defined. Any policy or legally established principle that will result in preferential treatment for one group should be stated explicitly and justified. For example, preferential treatment of poorer people could be justified on the basis of social objectives such as alleviating poverty, while favouring local residents may be justifiable on the basis of creating incentives to encourage local residents to play a role in coastal management. Guidelines for determining exactly who qualifies for preferential treatment may be difficult to devise but should be as clear as possible. Although the general principle may be clear, in practice it may be difficult to determine with precision what is meant by terms such as: "poor", "coast dependant" or "subsistence".

\subsection{Protected Areas}

One of the most widely used legal measures for the protection of natural and cultural heritage is the establishment of protected areas, usually under the control of conservation authorities. Most developments and environmentally harmful activities are either prohibited or severely restricted within protected areas. The maintenance or establishment of protected areas within the coastal zone are an important part of any ICM programme. Although the reason for establishing such areas is often expressed as the protection or conservation of natural ecosystems, landscapes or cultural heritage, the social and economic role played by these areas should not be overlooked. Marine protected areas, for example, are today recognized as a very important mechanism for maintaining certain economically important fish stocks, while the existence of other protected areas may provide the basis for a local tourism industry.

The main difference between establishing a protected area along the coast and establishing one inland is that from an ecological perspective, it is usually desirable to establish a protected area which spans the interface between land and sea. In some countries, because the seashore has been treated historically as an administrative boundary, there may be legal obstacles to declaring such an area or establishing a single authority to manage it. This may result in the undesirable situation of a terrestrial protected area being managed by one authority while the adjacent marine protected area is managed by another. In order for protected areas to be fully effective as a mechanism for achieving 
ICM objectives, it is essential that there is a legislative basis, firstly for declaring protected areas that include both land and sea, and secondly, for establishing a single management authority with appropriate powers to enforce the legislation throughout the area. From an ICM perspective it is also appropriate to provide different categories of protected area or different categories within a protected area to permit different uses in different parts of it. Allowing some human activities with a low environmental impact to take place within defined zones of a protected area or in adjacent buffer zones may also make it easier to have areas proclaimed as protected areas.

\subsection{Maintaining Environmental Quality}

Any legal commitment to conserving the coastal commons for the benefit of present and future generations is meaningless unless the custodians of the coast are under specific duties to monitor the state of the coastal environment and to take appropriate action to maintain environmental quality. There are many approaches to maintaining environmental quality, the most favoured being the prohibition or restriction of those activities considered to be the most environmentally damaging, such as waste disposal, water pollution and mineral extraction. However, central to this task is the identification of appropriate environmental quality objectives which can then be used as a focus for management activities. These may include scientific standards such as a maximum concentration of a pollutant in coastal waters, to more qualitative indicators relating to, for example, the rehabilitation of particular ecosystems or enhancing the ability of coast-dependent communities to provide for themselves. These objectives are often understood merely as management objectives and references to them may be almost entirely absent from legislation. However, the effectiveness of environmental quality objectives and indicators can be enhanced if they are consciously integrated into both the coastal planning systems and the systems for allocating coastal resources. For example, legislation can be used to require coastal management plans to include specific, verifiable, coastal management objectives (e.g. a specific water quality standard) and then require that public authorities both formulate other sectoral or local plans and use their powers to authorize the use of coastal resources, in such a way that they support rather than prejudice the attainment of these objectives. This would mean that a water authority considering whether or not to grant a licence to discharge pollutants into a river would be required to consider the potential implications for the achievement of water quality objectives for the coastal waters in the vicinity of the mouth of the river. 


\subsection{Preserving the Natural Character of the Coast}

One of the main concerns of many ICM initiatives is to prevent the natural character of the coast from being destroyed by development. For example in France, as a general rule the inter-tidal zone and the seashore, which are part of coastal public property (the domaine public maritime) must be preserved in their natural state.

In New Zealand concerns about increasing coastal degradation led to the phrase "preservation of the natural character of the coastal environment"242. For example, section 6(a) of the Resource Management Act lists as a matter of national importance:

"To recognise and provide for the preservation of the natural character of the coastal environment (including the coastal marine area), wetlands, and lakes and rivers and their margins, and the protection from inappropriate subdivision, use, and development" (emphasis added).

The term "natural character" was not defined in any legislation and its meaning has been evolving over time, particularly as a result of judgements interpreting the phrase. In this sense, it represents an interesting example of how a relatively broad and imprecise statement of principle can acquire a more legally precise meaning over time, which makes it easier to enforce. The concept has also proved to be a useful mechanism since it is sufficiently flexible to have adapted to different situations and changing views as to what is "natural". For example, in the early 1970s the concept of natural character was interpreted with an emphasis on the scenic quality of the coast, whereas since the late 1980s there has been a strong focus on ecological values.

The courts have interpreted "natural character" to be a product of nature, and accordingly have concluded that it does not include features constructed by humans ${ }^{243}$. The courts have accepted that the natural character goes beyond visual attributes and includes ecological and biotic systems and the

242 The phrase first appeared in an amendment of the Town and County Planning Act, 1973, then in the Reserves Act, 1977, and then in section 6(a) of the Resource Management Act, 1991. (See "Natural Character Concept Development in New Zealand Planning Law and Policy", Environment Waikato Regional Council (www.ew.govt.nz).

243 Harrison $v$ Tasman District Council 1993. 
elements, patterns and processes of those systems. However, the courts have interpreted "natural" to mean more than indigenous or original elements of the environment and have regarded introduced natural components such as exotic vegetation to be part of the natural character. The courts have also recognized that the degree to which an environment is natural varies from pristine at one end of the spectrum to a built up environment at the other end of the spectrum. Accordingly, consent authorities are under an obligation to consider the natural character of the coastal environment, regardless of the condition of the environment. Once this has been determined, unmodified coastal environments will have the highest priority for protection preservation because they are the most natural in character, but since there will always be some degree of natural character, this will always be an issue and the preservation of the remaining natural character in modified environments must also be considered. The courts have also interpreted "preservation" to be a stricter requirement than "protection" but have ruled that "absolute protection is not to be given to the coastal environment: that a reasonable rather than a strict assessment is called for" 244

244 Environmental Defence Society $v$ Mangonui County Council 1989. 


\section{TECHNIQUES FOR GUIDING INFRA-STRUCTURAL DEVELOPMENT}

\subsection{Introduction}

The construction of inappropriate buildings and infrastructure such as roads, breakwaters and offshore pipelines, represents one of the greatest threats to coastal areas. From a legal perspective, responding to this challenge involves two distinct but inter-related approaches. The first is to proactively plan the use of coastal areas to promote their optimal use and to minimize the potential for future conflicts. For example, the long-term sustainability of mariculture is heavily dependent on the maintenance of good water quality. Achieving this requires planning, firstly to designate areas for mariculture, and secondly to ensure that polluting activities are not permitted in other areas if pollution from them could affect the mariculture zone (e.g. due to prevailing currents). Planning is therefore a proactive approach that seeks to guide future construction and development of coastal areas, primarily by dictating or influencing where certain activities may or may not, be sited. The main legal instruments used for coastal planning are discussed in section 9.2 below.

The second, related approach, is development control. This typically involves a system whereby someone who wishes to construct buildings or other infrastructure within a particular area is required to obtain authorization to do so. In deciding whether or not to grant the authorization for a particular development the authorities are usually required to consider a range of factors, including whether or not the proposed development is consistent with any applicable plans. In many countries if the proposed development will occur in an environmentally sensitive area such as near the coast, or has the potential to cause significant environmental damage, an environmental impact assessment (EIA) must be undertaken. Legal mechanisms for development control are discussed in section 9.3 below. 


\subsection{Planning Instruments}

A variety of legal instruments have been used to plan coastal areas for ICM purposes. Some of the most common and important techniques are discussed here, namely:

- changing the legal status of certain coastal areas in order to restrict the manner in which they may be used, for example, by establishing public servitudes over the land as has been done in Spain (see section 9.2.1);

- establishing "set-back lines" along the coast and prohibiting certain activities, such as the construction of buildings, on the seaward side of these lines (see section 9.2.2);

- establishing multiple special purpose zones within the coast zone with different management regimes, for example in each area different activities may be prohibited or restricted, and different controls on development may apply, (see section 9.2.3);

- the zoning of areas of land and sea to reserve these areas for particular use (see section 9.2.4).

It is important to appreciate that, although these techniques are discussed here under separate headings, most of the countries discussed use more than one technique simultaneously. For example, in Spain the legal status of certain coastal land has been changed by imposing easements but this technique is also linked with the municipal zoning systems, and exhibits many of the characteristics discussed in relation to buffer zones.

The use of these techniques reflects the understanding that there are many situations in which it is not possible to protect the ecological integrity of a relatively narrow strip of coastal public property (e.g. the inter-tidal zone and coastal waters) without imposing restrictions on certain uses of land immediately landward of the foreshore.

\subsubsection{Changing the Legal Status of Land Adjacent to the Seashore}

\section{Spain}

The Spanish coastal zone regime established under the umbrella of the Ley de Costas of 1988, applies to a core foreshore area which is incorporated into the 
public domain, accompanied by partly overlapping layers of easements (public servitudes) over adjacent private land holdings.

The core area of coastal public property (dominio publico maritimo-terrestre) comprises (a) the seashore and coastal waters which include the foreshore and coastal wetlands; (b) beaches, including berms and dunes; (c) territorial and inland waters including their beds and subsoil; (d) natural resources of the continental shelf and the economic zone; (e) other categories enumerated exhaustively such as accretions to the seashore, land invaded by the sea, reclaimed land, small islands, artificial additions, coastal and harbour works and installations ${ }^{245}$.

The boundaries of this area of public property must be delimited by the Government through statutory proceedings which provide for the hearing of regional governments, local towns, private owners, and anybody who has an interest in the case ${ }^{246}$. Use of this coastal public property is to be free and public for common and natural uses ${ }^{247}$. Occupation is only allowed for activities and installations which by their nature cannot be located elsewhere. Specified activities and constructions are also forbidden in the Protection Easement Zone (see below), regardless of whether any right to the contrary had been granted ${ }^{248}$. Beaches are permanently excluded from being reserved for private use, but exceptions may be granted for public property reserves, and installations for beach-related activities are allowed ${ }^{249}$. Concessions for occupation of public coastal property, in addition to other possible permits and controls, have to be obtained from the government. They may not exceed 30 years, are subject to prior public notification, and may be registered in the Real Estate Registry. The law further prescribes fees and excise taxes to be levied, and the bonds which have to be posted by applicants and grantees ${ }^{250}$.

The law envisions the creation of a Protection Easement zone, with a minimum of 100 metres and a maximum of 200 metres landward from the

245 For a precise enumeration, see sections 3 and 4 of the 1988 Shores Act.

246 Ibid., Title I, Chapter III.

247 Ibid., section 31.

248 Ibid., sections 25 and 32.

249 Ibid., section 33.

250 Ibid., sections 82-89. 
dominio public maritimo-terrestre. Activities generally forbidden are: farming; plantations; buildings for residential purposes; construction or alteration of roads and motorways above a certain traffic density; destruction of deposits of sand, stone, gravel; laying of high-tension electric cables in the atmosphere; disposal of solid waste, rubbish, and untreated sewage; advertising by posting, acoustic or audiovisual means. Possible exceptions may be granted subject to different government authorizations and rules, for construction of roads, cables, and activities which by their nature may not be located elsewhere, or which provide necessary or even convenient services, as well as outdoor sports installations ${ }^{251}$.

A Right of Passage Easement of 60 to 20 metres depending on the level of danger or difficulty of the passage is imposed from the landward limit of the shoreline, to ensure permanent access for pedestrians and rescue vehicles. Exceptionally, coastal public works may be allowed to block the passage, and seafront promenades may be built ${ }^{252}$.

The Access to the Sea Easement mandates town zoning plans, except in special protection areas, to allow for the construction of sufficient access roads to the sea, with an obligatory break of 500 meters in between roads for motor vehicles, and 200 metres for pedestrian access roads ${ }^{253}$.

The Zone of Influence to the dominio publico maritimo terrestre, is a further means by which the Spanish central authorities impose principles regarding territorial land-use and zoning planning and regulation. The local authorities are required to provide for parking facilities pursuant to the Access to the Sea Easement, and to take care that building does not result in an uninterrupted screen or in excessive accumulation of volume; more precisely, the building density shall not exceed the average planned for zones classified as "for development" or "suitable for development". All uses entailing disposal of waste shall be subject to the same authorization as in the public property zone 254 .

251 Ibid., sections 23-26.

252 Ibid., section 27.

253 Ibid., section 28.

254 Ibid., section 30 for the zone of influence; Ibid., sections 56-62 for waste disposals. 


\subsubsection{Coastal Set-Back Lines and Exclusion Zones}

This involves the prohibition or severe restriction of certain uses of the coast (such as the construction of buildings and roads) within a specific distance from the shoreline. Unlike special areas management this legal tool is usually applied in respect of a narrow but lengthy strip of land along the shore 255 .

Setback rules usually form part of physical development plans or zoning and land-use plans, and they can be a first, relatively inexpensive step to put a moratorium on development encroaching into coastal areas. This is evident where the coastal strip is subdivided in several sub-zones with rules and exclusions becoming more stringent as one gets closer to the shore. For some countries (India, Costa Rica) all existing ICM legislation is built around this exclusion regime, with the result that the ICM legislative regime lacks a marine component. In other jurisdictions (Western Australia, France) it is but one of many tools forming part of a wider ICM legislative framework.

This legal measure tends to be popular with legislators because it is:

1. easy to establish where no private property rights exist or where there has been little development (it is usually also popular with people further inland);

2. relatively cheap to enforce; and

3. can be targeted at one or more specific problem sectors.

It should be noted that existing building or land-use planning legislation can often be used to impose restrictions on the nature of buildings and infrastructure that may be erected along the coast. Using such legislation can be particularly effective in dealing with the aesthetic impacts of buildings on the coast. For example, in certain areas it may be important to prohibit buildings within a certain area or place restrictions on their height, character or appearance in order to preserve coastal landscapes. However this approach is limited in the long run and the scope of the legislation under which such restrictions are imposed usually does not allow for the

255 Sorensen et al., 1984, p. 68 for basic description of setback rules and some comparative overview of selected examples. 
development of a system of sub-categories of coastal areas with different management regimes.

The legal origins of this technique are heavily influenced by public trust, public domain or related concepts. In most of the countries examined, these concepts were intended to protect rights such as the public's right of access to the shore, or State ownership of the nation's shores in the public interest. Nowadays the shores in former or present Commonwealth countries are still held in trust for the public (the rights are vested in the Crown). In many Latin American and Americas countries they are declared part of the national heritage (e.g. Costa Rica). In civil law countries, the shores are simply part of the inalienable state property, originally reserved to the State for security reasons (e.g. domaine public maritime and cinquante pas géométriques in France).

Rules of this kind are insufficient to establish coastal area management, and must be accompanied by other measures. For example, in combating natural or human induced or aggravated "beach erosion" or "shoreline retreat"256 it would be appropriate to combine shoreline exclusion or setback with proactive methods of protecting or ameliorating the coast lines such as coastal defence or beach renovation (sometimes referred to as "hard" or "soft" approaches respectively) ${ }^{257}$.

Setback rules vary substantially in terms of: the base line and width of the exclusion zone; the types of activities and uses excluded or restricted; and the contents and context of the exclusion regime. The breadth of the exclusion zone tends to vary from $100 \mathrm{~m}$ to $1000 \mathrm{~m}$.

Often the choice of the baseline from which the setback line is measured is based on the incorrect assumption that coasts are static. Only a few jurisdictions (South Carolina and a few other states in the USA, and the State of Western Australia) have adopted shoreland exclusion rules which enable

256 CAMPNET, 1991, p. 15.

257 See Charlier R.H. and De Meyer C.P. 1989. Coastal Defence and Beach Renovation, special issue of Ocean \& Shoreline Management, vol. 12, Nos. 5 and 6, pp. 535-545. 
the boundaries of the zone to vary in accordance with local erosion and deposition 258 .

The Western Australia setback rules take into account the local erosion rate using a 100 years time frame (see Box 16 below), whereas in South Carolina a 40 years time frame has been adopted. A comparable method was followed by the Sri Lanka Coast Conservation Department which adopted a general setback rule which is adapted on an area-by-area basis.

\section{Denmark}

In Denmark stretches of the North and Middle Jutland Coast are protected because of dune erosion hazards ${ }^{259}$. The exclusion or protection zones encompass the beach, areas within 100 metres from the beach and some sea sand areas, and may be extended by the dune authorities. Under the regime, activities such as construction, cultivation, hedge cutting, and gravel pit exploitation are forbidden. The primary dune authority is the National Forest and Nature Agency. It combats dune erosion using public funds, and the competent dune authorities may even order measures at the expense of the owner in non-protected areas ${ }^{260}$.

\section{Sweden}

The Swedish Environment Code provides for "shore protection areas" along the shores of seas, lakes and watercourses in order to guarantee public access to these water bodies for recreational purposes and to protect the habitats of terrestrial and aquatic plant and animal species. The shore protection area extends 100 metres from the shore line at the normal average water level but the area may be extended by the authorities to a maximum of 300 metres from the shoreline if this is necessary to fulfil any of the purposes of the

258 For an example of how static setback rules can become obsolete because of coastal erosion see Parish D. 1991. Moving Boundaries: Erosion Cycles and Coastal Protected Areas, in CAMPNET, p. 59.

259 Dune erosion areas are regulated by Promulgation Order No. 168 of 28 April 1982 and Statutory order No. 271 of 19 June 1979, on Sand Drift Control.

260 See Basse E.M., "Denmark" in International Encyclopaedia of Laws: Environmental Law, (Supp. 11), Kluwer, December 1994), p. 138. 
shoreline protection. If a particular shore area is not important for the purposes of shore protection and is included in a detailed development plan or regulations under the Planning and Building Act, it may be exempt from the shore protection regime.

Within shore protection areas a number of activities are prohibited including: the erection of new buildings, the alteration of buildings to change their purpose, the erection of other structures or works which hinder public access to the area or which may have a significant effect on the habitats of plant or animal species, and any other measures which may significantly affect the living conditions of animal and plant species. Exceptions are more for buildings, structures, and works or measures necessary for certain activities, including agriculture, fishing, forestry or reindeer husbandry ${ }^{261}$.

\section{Sri Lanka}

The Sri Lankan 1990 Coastal Zone Management Plan, in execution of the 1981 Coast Conservation Act, establishes as "good planning practice" a setback of 60 meters from the mean sea level line. However, the Coast Conservation Department has issued detailed setback standards on an areaby-area basis for the entire coastline of the country. Furthermore, setback lines, ranging from 0 to 100 metres, have been detailed for each of the following construction and development activities: dwelling units, communal and industrial units, non-water dependent activities, and tourism development. Setback lines for water dependent activities such as aquaculture and boat yards are determined on a case-by-case basis ${ }^{262}$.

\section{France}

The 1986 Loi littoral regulates development and other activities pertaining to the shores, the beaches and a buffer zone. Under the Loi littoral, in nonurbanized zones, buildings and facilities are prohibited within a strip of 100 meters from the landward limit of the shoreline or from the high-water mark of the internal waters (bande littorale non constructible) ${ }^{263}$. In order to

261 Environmental Code, Ch. 7, sections 13-17.

2621990 Coastal Zone Management Plan, pp. 10-18.

263 Article 146-4, III of the Code de l'urbanisme, introduced by article 3 of the Loi littoral. 
demarcate the shoreline which serves as the baseline line for the setback, the State first determines the limits on the basis of scientific data, and then the results are submitted to public inquiry and riparian owners are notified they will have a right of recourse for the next 10 years 264 .

The aim is to preserve the inter-tidal zone and the shores (which are part of the domaine public maritime) in their natural state. Consequently, activities such as building embankments, filling wetlands, making artificial rocks, filling ditches and the like, are forbidden ${ }^{265}$. Exceptions include the industrial zone of the harbours, coastal defence works, works necessary for marine security, salt extraction and mariculture, works and installations linked with a public service which needs to be located at the seashore, subject to a declaration of public utility.

The beaches which in principle are also part of the domaine public maritime are declared to be freely accessible for pedestrians, while most motor vehicles are forbidden. Beach concessions are issued and renewed subject to public inquiry and should leave public access to a strip of significant width along the sea ${ }^{266}$.

The prohibition on construction within the bande littorale non constructible is not applicable to:

- buildings and facilities necessary for public service or economic activities which need to be near water (in such cases a public inquiry in accordance with the law 267 is necessary); or

- works for maritime and airspace security, airports, national defence, public security, or harbour services other than for marinas, which need to be located within this exclusion zone ${ }^{268}$.

\footnotetext{
264 Loi littoral, article 26.

265 Loi littoral, articles 26 and 27.

266 Loi littoral, article 30.

267 Law No. 83-630 of 12 July 1983: Loi n 83-630 du 12 juillet 1983 relative à la Démocratisation des Enquetes publiques et à la protection de l'environnement.

268 Article 146-8, Code de l'urbanisme, article 3, Loi littoral.
} 
A local zoning and land-use scheme (plan d'occupation des sols, POS) may extend this coastal exclusion zone to more than 100 metres when justified by the sensitivity of the environment or by coastal erosion.

As a general rule, no new roads are allowed on beaches, lagoons, dunes, or on the shores. New transit routes must be located at least 2000 metres from the shore ${ }^{269}$. If the particular geography so dictates, and after consultation of the regional authorities, exceptions may be allowed.

The French exclusion regime consists of a complex combination of general rules with many exceptions, which make the assessment of the whole difficult $^{270}$. For example, the rule of a 100 metres bande littorale non-constructible, could be paralysed by two exceptions: (1) the provision is not applicable outside urbanized zones (en dehors des espaces urbanisées) and (2) constructions or installations for public service or economic activities which need the proximity of the water are exempt. Moreover, the Loi Littoral leaves the task of determining whether a zone is urbanized or not to the administrative tribunals. The Conseil d'Etat decided in 1985 that the presence of eight buildings in the 100 meter zone indicated that the zone was urbanized in terms of the Code de l'urbanisme. Yet other tribunals have refused to apply mere quantitative criteria ${ }^{271}$.

The same is true for the second exception, for no criteria on the concept of water-proximity are laid down in the Loi littoral. Due to technological advances, fewer activities are dependent on being located on the coast. It is a moot question as to whether or not the courts should take into account the latest technological developments in determining whether or not a proposed development is "water dependent" 272 .

269 Article 146-7, Code de l'urbanisme, article 3, Loi littoral.

270 See Becet \& Le Morvan, 1991, p. 128 ff.

271 Becet and Le Morvan, ibid., discuss a court case where purely quantitative criteria were adopted to determine the extent of urbanization (the number of buildings), and other judgments that reject purely quantitative criteria.

272 Becet and Le Morvan, ibid., p. 133, mention a 1987 judgement of the administrative tribunal in Nice which declared that a centre for thalassotherapy is not an facility which needs to be located next to the water. 
Furthermore, this entire exclusion regime apparently needed to be relaxed for the French overseas regional subdivisions (départments d'Outre-Mer, DOM), where existing built-up tourism facilities would have rendered the prescribed exclusion zone devoid of practical meaning. In the DOM the Loi littoral marks a return to the institution of colonial origin, the "cinquante pas géometriques" or fifty geometric paces ${ }^{273}$, which it declares to belong to the domaine public maritime ${ }^{274}$. For reasons of harmonization, the zone of noncontructibilite, has been equated, wherever possible, with these 50 geometric paces (81.20 meters). I $\mathrm{n}$ addition, the exceptions to this prohibition on construction are formulated in a more flexible way. The exclusion does not apply in zones with "diffuse urbanization", leaving room for various types of human settlements and activities. Installations for public services, economic activities and collective equipment when linked with the use of the sea, are not forbidden, although they should preserve the principles of free access and movement along the shore ${ }^{275}$.

\subsubsection{Multiple Special-Purpose Zones}

One of the effects of applying area-based restrictions on the use of the coastal zone is that over time sub-zones of the coastal zone are created, each with different management regimes. Usually there are at least two zones; the core area of foreshore (usually subject to a special ownership regime) and an area inland of this within which use restrictions are imposed. However some countries like Spain and India have a range of different designations (and rules) for different coastal areas.

The primary purpose of introducing restrictions on land inland of the foreshore area was usually to help to protect the coast itself. However it has become increasingly apparent that imposing restrictions on the use of such areas may be equally important to protect people and the environment inland from flooding, storms and other coastal hazards. Sea-level rise induced by climate change has made the establishment of such protection zones even more important, particularly since it is likely to be accompanied by changes

273 A modern form of a Roman pace, a measure of length taken as 5 feet.

274 Article 37, Loi littoral.

275 Article 35, Loi littoral; See Douence J.-C., 1987. La Loi littoral dans les Départements d'Outre-Mer, in La Loi littoral, op cit., pp. 44 and 45. 
in coastal land formations and increases in the number and severity of storms.

When establishing different zones within the coastal zone as a whole, it is important to define the purpose of doing so, as this will help to guide both the process of demarcating and adjusting the boundaries of the area and the nature of the legal rules imposed within that area. For example, a coastal protection area or buffer zone might be established inland of the foreshore area defined as coastal public property, for the purpose of enabling the use of adjacent land to be managed, regulated or restricted in order:

(a) to protect the ecological integrity and natural features, and the economic, social and aesthetic value, of coastal public property;

(b) to avoid increasing the incidence or severity of natural hazards in the coastal zone;

(c) to protect people, property and economic activities from risks arising from dynamic coastal processes, including the risk of sea-level rise;

(d) to maintain the natural functioning of the coastline;

(e) to maintain the productive capacity of the coastal zone by protecting the ecological integrity of the coastal environment; and

(f) to make land near the seashore available to the State and other authorized persons for performing rescue operations and temporarily depositing objects and materials washed up by the sea or tidal waters.

\section{Costa Rica}

The Zona Maritimo Terrestre (ZMT) law of 2 March 1977276 is the core of the Costa Rican ICM legislative framework. The law defines a fringe of land 200 meters wide as the zona maritimo terrestre (ZMT) which is part of the national heritage and the public domain. The ZMT is measured inland from the mean high tide line (pleamar ordinaria) ${ }^{277}$ and from the land and rocks

276 Ley $N^{\circ} 6043$ sobre la Zona Maritimo Terrestre y su Reglamento, amended several times, and enabling legislation Reglamento a la Ley sobre la Zona Maritimo Terrestre, Presidential Decree No. 7841-P ("the decree").

277 For detailed description of the pleamar ordinaria see article 2 of the decree. 
which are not covered during the low tide 278 along the two oceans bordering Costa Rica (the Atlantic and the Pacific).

The first fifty metres inland is designated as "la Zona Pública"and the rest of the ZMT as the "Zona Restringida". The Zona Pública is basically destined for public access and pedestrian transit and cannot be privately appropriated or developed, except for infrastructure in the public interest ${ }^{279}$ or summer tourism facilities 280 approved or executed, as may be the case, by the Ministry for Public Works and Transport, the Costa Rican Institute for Tourism (ICT), or the National Institute of Urban and Rural development (INVU).

Sectors exempt from the prohibition ${ }^{281}$ must nevertheless ensure some public access and transit. ${ }^{282}$ In the Zona Restringida (and in the Zona Pública, where allowed) activities are subject to an authorization and/or a concession system. Developments must be in accordance with a hierarchy of plans comprising sectoral planning, protected areas, special area plans, land-use plans etc. Authorization must often be obtained from different government departments and concessions from the municipalities. The law prioritizes activities and uses pursuant to a hierarchy of preferred uses, depending on whether the zone is designated by the ICT to be of tourism value.

No construction activity in the ZMT is allowed until the ICT has decided on the designation status of the area ${ }^{283}$ and no concession may be granted ${ }^{284}$ for tourism uses without an existing development plan either drafted or approved by the ICT or the INVU. The consents must also conform to the General Land-Use plan for the ZMT ${ }^{285}$, which will be developed at the national level within the National Plan for Tourism Development, and other plans such as the detailed regulation plan designed by the local canton in

278 ZMT law, articles 1 and 9.

279 Ibid., article 22.

280 ZMT decree, article 11.

281 Such as shore-dependent activities, as defined in article 18 of the law, coastal strips with a particular geography, topography or other conditions which merit exemption as laid down in article 21 of the law, and infrastructure or works for public use and tourism facilities as in article 22 of the law.

282 ZMT decree, article 12.

283 Ibid., article 15.

284 Ibid., article 19.

285 Ibid., article 17. 
collaboration with the ICT and the National Institute for Housing and Urbanization.

The Costa Rican Law has been described as an ambitious shoreland restriction programme 286 . However, the law itself does not halt construction activities; the emphasis is on orderly, planned development of tourism facilities. Whereas the municipalities of the cantons are the primary administrators of the areas of the ZMT within their jurisdiction, the overall authority for the law does not fall on environmental authorities, but on the Costa Rican Institute for Tourism (ICT) ${ }^{287}$. The latter reportedly is neither equipped nor authorized to do anything beyond the promotion of tourism. This becomes even clearer when considering that the development plans in the ZMT are only mandatory for concession areas designated as tourism zones by the ICT. ${ }^{288}$ Furthermore, under the ZMT law, concessions are to be issued on a priority basis in tourism zones, for land uses that are tourism or recreation oriented. The order of preference is as follows: (1) tourism activities, as determined by ICT, (2) recreation and sports activities, (3) residential use, (4) commercial and artisanal activities, (5) fisheries other than for sports, agriculture, industrial activities 289 .

The ZMT law only applies to parts of the coastal fringe and significant portions of the coast and sectors are regulated separately. It does not affect ${ }^{290}$ the cities situated on the coast and allows for the construction of industrial plants, fishing installations, harbour works and mariculture etc., if these activities need to be in the vicinity of the water ${ }^{291}$. It does not apply to or change the legal status of plots situated within the ZMT that are either in private ownership or recognized as private by existing laws - an exemption which excludes at least 25 to 30 percent of the coast from the application of

286 Sorensen J. C. and Brandani A. 1987. An Overview of Coastal Management Efforts in Latin America, Coastal Management, vol. 15, p. 19.

287 ZMT law, article 2.

288 ZMT decree, article 19.

289 Ibid., article 57; for areas designated as non-tourism zones the order of preference is as follows: (1) fisheries other than for sports, agriculture, industrial activities; (2) residential use; (3) commercial and artisanal activities; (4) recreation and sports activities; and (5) tourism activities.

290 ZMT law, article 6.

291 Ibid., article 18. 
the ZMT legislation ${ }^{292}$. Furthermore, a coastal strip without tourism value may fall under the ZMT law, but under no development plan since this is not mandatory for regions other than of tourism value. Further exemptions relate to the areas (mainly mangroves on the Pacific coast) within the jurisdiction of the Forest Service ${ }^{293}$, and to a ten-kilometre wide coastal strip between Moin and Barra del Rio Colorado on the Atlantic Coast, administered by a port authority 294 .

\subsubsection{Zoning}

Many countries use zoning as one of the principal means of guiding the development of land. Historically, areas were designated spatially and given a single use designation such as agricultural, low-density residential, industrial, etc. This traditional approach, known as "Euclidean zoning", has been replaced in many countries by approaches, such as overlay zoning, in which zones established for different purposes may overlap (e.g. a zone in which only single storey buildings are permitted may overlap with both areas designated for industrial use and areas designated for residential use). In addition, there is a trend in many countries towards allowing multiple uses of particular areas provided that the uses in question are consistent with predetermined land management objectives for the areas in question.

292 Sorensen and Brandani, 1987, op cit., at p. 19 say 25 percent, a personal communication received by the FAO Development Law Service from Costa Rica says 30 percent.

293 Article 73 of the ZMT law, and article 4 of the ZMT decree relating to the Mangrove forests, of which the country has some 30000 ha with 99 percent on the Pacific Coast. As Forest Reserves, they are nominally under the jurisdiction of the National Forest Service (DGF) and are administered as forest reserves by the relevant regional offices (source: personal communication from Costa Rica, received by FAO Development Law Department). The Forestry Law requires a management plan for the exploitation of the forest reserves (Forestry Law 1986, revised in 1990).

294 The Junta de Administrativa Portuaria de Desarrollo Economico de la Vertiente Atlantica (JAPDEVA), administers this strip. Article 75 of the ZMT law places the principal canals, which are used for banana plantations, under the ZMT law, but does not explicitly mention or set criteria for identifying those canals. 
Zoning has traditionally been a tool of land use management and there are relatively few examples of its being extended to coastal waters, although in principle there is no reason why it should not be adapted for this purpose. Exceptions include the SMVM law in France (which introduces a system of zoning for marine areas). This only has the potential to be an important instrument in managing the use of the coast, particularly in designating use areas in inshore waters (e.g. for bathing, power boating or jet-skiing, sailing or fishing) and for reserving marine and coastal areas for activities such as aquaculture and mariculture. However, since boundaries are more difficult to define in the marine environment, enforcing zoning restrictions can be more difficult.

In many countries, terrestrial zoning and land use restrictions are administered at the local government level and are consequently frequently affected by local politics and the desire to increase municipal revenues by encouraging developments which would increase local property values and rates payable to municipalities. On the other hand, local authorities and people usually have a better knowledge of local coastal environments and should be in a good position to make zoning decisions. Proper public participation procedures can function as an important safeguard in this regard.

\section{India}

The Indian Notification of 10 February $1991^{295}$ sets boundaries for a narrow Coastal Regulation Zone consisting of the strip of land between the Low Tide Line (LTL) and the High Tide Line (HTL) and 500 meters inland from the HTL; and regulates a whole series of activities and uses. The Annex to the Notification classifies the inter-tidal zone and the area landward from the HTL into four categories. These are the fixed upland and offshore dimensions, and different corresponding restrictions on construction and land use (see Box 16). The coastal states and the Union Territory administrations were required to prepare Coastal Zone Management plans in accordance with certain zoning and other principles, within one year from the date of the Notification.

295 Published in the Gazette of India, 20 February 1991, SO No. 114 (E). 
The Notification amounts to an attempt to prevent uncontrolled and environmentally harmful development and uses a number of techniques to achieve its purposes. Firstly, the Notification prohibits a series of industrial and construction activities. Secondly, it lists activities requiring clearance by environmental authorities before they will be permitted in the regulated zone. (According to the Notification, this clearance will be given only if the uses require water and shorefront facilities, but the rules do not indicate unambiguously whether the principles for prohibition and clearance are mutually exclusive.) Thirdly, the Annex to the Notification introduces specific rules applying to construction and development in four zoning categories.

India's 1991 Coastal Regulation Zone is a good example of a coastal management law which is built around a set of existing development "realities". The core of the regulation is a moratorium on new construction, such as in ecologically sensitive areas, and a prohibition of most development activities between the LTL and the HTL. The 500 metre zone can be considered as a buffer zone where, whenever possible, construction is being curtailed. The rather complex formulation of the rules is obviously the result of an attempt on the part of the Indian government to devise a comprehensive legislative framework for the coastal zone without compromising economic development, or rendering existing facilities or built-up areas illegal.

\section{Box 16 \\ COASTAL ZONING CATEGORIES AND RESTRICTIONS IN INDIA}

Category I areas (constituted by the intertidal area and areas that are ecologically sensitive and important such as national parks, mangroves, coral reefs, areas close to breeding and spawning grounds of fish and other marine life, areas of outstanding natural beauty, historical heritage areas, areas rich in genetic diversity, and areas likely to be inundated due to a rise in sea level).

Two exclusions apply here: no new construction shall be permitted within 500 meters of the HTL; and in the intertidal zone no new construction shall be permitted, except facilities for carrying treated effluents and waste waters into the pipelines and other permitted essential facilities; sea, facilities for carrying sea water for cooling purposes, oil, gas and similar. 
Category II areas (constituted by those areas that have already been developed up to or close to the shoreline. $)^{296}$

Buildings shall be permitted neither on the seaward side of the existing road, nor on the seaward side of authorized structures. On the landward side authorizations for construction and reconstruction need to conform to town and country planning regulations and the design and construction of buildings need to be consistent with the surrounding landscape and architectural styles;

Category III areas (areas which are relatively undisturbed and those that do not fall within categories I or II).

There is a "no development zone" within 200 metres inland from the HTL, meaning that only limited repairs to existing authorized structures are allowed. However agriculture, horticulture, gardens, pastures, parks, playfields, forestry, and operations to extract salt from sea water are allowed. With regard to vacant plots between 200 and 500 metres of the HTL; only hotels and beach resorts for temporary accommodation of tourists are allowed, and a ceiling on other dwellings of not more than twice the existing number is introduced;

Category IV areas (this area comprises the Andaman \& Nicobar islands, and Lakshadween and small islands if not included in the above categories).

Special rules apply to this area including: (1) a prohibition of new construction within 200 metres from the HTL; (2) between 200 and 500 metres from the HTL, only limited construction is permitted and the buildings must be in harmony with the surrounding landscape and architectural style; (3) corals and sand from coastal waters may not be used for any purpose; (4) dredging, underwater blasting in and around coral formations is prohibited. The Ministry for the Environment and Forests may also apply these special rules to areas in any of the preceding categories and in addition specific rules apply to Lakshadween and various small islands.

296 A developed area is defined in the Notification as an area within municipal or in other legally designated urban areas which is already "substantially" built up and which has been provided with drainage and approach roads and other infrastructure facilities, such as water supply and sewerage mains (Notification, Annexure I, article 6(1)). 


\subsubsection{Demarcating Zones}

If area-based restrictions on activities or uses of the coast are to be imposed, it is necessary:

(a) to define the area in question (e.g. a buffer zone, exclusion zone, or public access servitude) in such a way that it is extensive enough to achieve the purposes for which it was established, but not so extensive that it imposes unreasonable restrictions on the use of areas of land or sea;

(b) to define the boundaries of each area in a manner that enables their position to be determined with sufficient certainty to enable the public and the regulators to know whether or not particular restrictions apply;

(c) to enable the boundaries to be varied to accommodate different conditions along the coast and to deal with changes in the coastline itself (e.g. caused by erosion, accretion or sea-level rise).

In order to achieve its objectives, a coastal protection zone may need to be several kilometres wide in some areas while in others, for example, where there are sea cliffs, a breadth of 100 metres or so may suffice. The difficulty facing ICM legislators is that if the breadth of the protection zone is determined on a site-specific basis, it is likely to involve a great deal of time and public expenditure and may be impractical. On the other hand, if an arbitrary distance of, say, one kilometre inland from the high water mark is established, this may result in the imposition of unnecessary restrictions in some areas, particularly in urban areas, while failing to protect other important coastal resources such as wetlands.

One approach may be to enact legislation that provides for the establishment of a coastal protection zone of a defined width (e.g. 100 metres inland from the high water mark in urban areas and one kilometre in other areas) but that establishes a procedure for adjusting the boundaries of this zone. For example, coastal municipalities or other appropriate parties could be authorized to initiate a process to adjust the inland boundary of the coastal protection zone in order to make it more appropriate to local conditions. If this approach is adopted, it is important to specify both the purpose for which the coastal protection zone is established, and the basic elements of the adjustment procedure (e.g. requirements for public participation and an 
assessment of the environmental implications of shifting the boundary of the coastal protection zone) to ensure that a consistent approach is adopted nationally.

\section{South Carolina}

South Carolina's $300 \mathrm{~km}$ of ocean beaches are extremely variable with some beaches eroding at more than 3 meters per year, while others are building seaward at comparable rates. Only 25 percent of the coast is changing at less than half a metre per year. Therefore, the Beach Management Act of 1988, administered by the South Carolina Coastal Council, introduced buffer zones between the ocean and upland property over which the littoral zone is expected to move. Using scientific information and evidence, the Act prescribes the width of the setback as a distance 40 times the annual erosion rate measured from the most seaward dune. Where no shoreline change data exist, some arbitrary distance which is considered reasonable and prudent is prescribed until site specific data become available. This strategic retreat is usable only where no development exists (about 50 percent of the South Carolina coast.) $)^{297}$

The South Carolina Law stands out because it ties the setback rules to the local erosion rates, accounts for the natural variation in shoreline trends from one beach to another, and because it adopts a precautionary approach in express terms.

\section{Western Australia}

The Western Australian setback criteria have the advantage of allowing for adaptation of the rules to natural as well as artificial (human-made or induced) alterations of the shores. According to its Country Coastal Policy guidelines on land preservation, set back lines will be determined by the Coastal Management Coordinating Committee (CMCC) after consultation with other interested State agencies, such as the Department of Agriculture, the Department of Marine and Harbours, the Waterways Commission, and

297 See Kana T.W., 1991. Treating the Coast as a dynamic System, CAMPNET, p. 60. 
the responsible local authorities ${ }^{298}$. The criteria used by the CMCC in determining setback lines are set out in Box 17.

\section{Box 17}

\section{CRITERIA USED TO DETERMINE SETBACK LINES IN WESTERN AUSTRALIA}

(a) Sandy coasts:

- a minimum of 100 meters when land forms are stable, and wider if subject to coastal recession;

- the line of permanent vegetation should serve as a datum line; this and also the width of the exclusion zone will be set by the Commission in consultation with other agencies and local authorities;

- the setback line should be determined in relation to the stability of the land forms, ecological considerations and recreational requirements;

- where necessary, a recession component shall be calculated using a 100 year planning time frame;

(b) Rocky coasts:

- as a general rule the setback will be 100 meters from the cliff line, and take into account public amenities, recreation, and visual resources;

(c) Estuarine setbacks:

- the tidal and flooding characteristics which influence the high water mark;

- the changeable nature of estuarine mouths;

- the role of fringing vegetation as a biological filter;

- the need for conservation and recreation areas including wetlands;

- the need for a buffer zone at the water/land interface to allow for changes in bank alignment.

298 See Country Coastal Planning Policy, a Government Position Paper, October 1983, Coastal Planning and Management in Western Australia, guidelines 3.6. 


\subsubsection{Coastal Access}

A public right to use the coast may be virtually meaningless if physical access to the coast itself is restricted. This can be a significant factor, particularly in small island states where almost continuous rows of expensive hotels catering primarily for foreign tourists can have the effect of virtually excluding local people from the best beaches. It is therefore appropriate to provide legal mechanisms for ensuring that the public have access to the seashore itself and also are able to move along it, particularly where rocks or other coastal land forms mean that it is not possible to simply walk along the beach. This can be achieved in a number of ways, including by imposing public access servitudes as has been done in Spain, or by imposing an obligation on local municipalities to establish and signpost access points at regular intervals. In other countries such as Finland, Sweden and Norway, public access even across private land is normally guaranteed by the principles of Everyman's Law, but legislative interventions may still be required in densely populated urban areas.

\subsection{Development Control}

Uncontrolled, illegal and inappropriate infrastructural developments are one of the main reasons for the destruction of coastal ecosystems and the creation of coastal hazards such as erosion and flooding. It is not uncommon for particularly beautiful coastal landscapes to be marred by excessive tourist developments, and for any coastal areas to be spoilt by ribbon developments along the coast or environmental quality to be ruined by the consequences of excessive development such as the discharge of untreated sewerage into the sea.

Authorization processes are the main legal technique used to control undesirable infrastructural developments in coastal areas. These typically involve:

(a) the prohibition of certain categories of particularly environmentally harmful activities within specified coastal area (except under exceptional circumstances) ${ }^{299}$, and

299 For example: the construction or alteration of railways, highways or intercity roads, or service areas associated with such railways, highways or roads; mining or quarrying; the construction of aerial high-tension cables; and the disposal of solid waste, rubble, and unprocessed sewerage. 
(b) prohibiting a wide range of other building activities unless these have been authorized in advance, and subject to any terms and conditions imposed in the authorization. The authorization process usually involves the exercise of a judgement by an official (i.e. the exercise of administrative discretion) guided by relevant considerations, which should include any ICM principles incorporated in law.

In many cases, the decision as to whether or not to authorize such activities may not be made unless an environmental impact assessment has been conducted and the results considered by the decision-maker.

In India the Notification on the Coastal Regulation Zone ${ }^{300}$ classifies activities in two categories, those which are prohibited and those requiring environmental clearance. The Notification prohibits a series of activities enumerated exhaustively, such as the setting up of new or expansion of existing industries except those directly related to the water front or directly needing foreshore facilities; the setting up or expansion of fish processing facilities; most coastal engineering works; mineral and mining activity except when not available outside the zone; construction activities in ecologically sensitive areas; any construction activity in the zone between the HTL and the LTL. For all other activities, the Notification stipulates that only if they require water front and foreshore facilities will they receive clearance from the Ministry of the Environment.

\subsubsection{Discretionary Administrative Controls on Development}

One of the most frequently encountered legal mechanisms is the requirement that proposed uses of the coastal zone be subjected to administrative screening procedures whereby an official exercises a judgement as to whether or not to permit the use. Permits, consents, concessions, licensing, authorizations, environmental clearance, and similar procedures are all examples of the use of this tool.

In general, the discretionary screening procedure has a number of stages. The first step is to exclude activities which are prohibited by legislation. The second step is usually to require formal applications to be lodged with one or more administrative agencies in respect of activities which are not, in

300 Notification of 10 February 1991, SO No. 114(E). 
principle, prohibited. This is followed by an evaluation of the particular facts of the case and the authority will then exercise discretion to grant the application unconditionally, grant it subject to certain conditions, or deny it. In most instances the authorization is granted for a limited period, may be amended in certain circumstances, and may be subject to renewal.

There as many types of permits, consents, licences and concessions, as there are administrative acts and agencies responsible for the coastal zone. Because of this great variety, it is not possible to find standard definitions which could be applicable to all countries surveyed. Any review procedure for activities or uses in the coastal zone gives the State and its agents a powerful tool to direct, promote, restrict or exclude any activity or use in the coastal zone. In addition, revenue may be generated by the fees levied on the application or the grant, which can be used to further particular goals (e.g. Costa Rica and Sri Lanka).

Sri Lanka strictly forbids activities involving the removal of coral, save for scientific purposes, the latter subject to a licence issued by the Coast Conservation Director ${ }^{301}$. Most other activities likely to alter the physical nature of the coastal zone in any way, excluding fishing activities, require a permit ${ }^{302}$. Fifty percent of the fines imposed for erecting or building unauthorized structures or for engaging in any forbidden or unauthorized activity in the Coastal Zone, will be credited to the Police Reward Fund ${ }^{303}$.

Under the ZMT law in Costa Rica, activities in the Zona Restringida, and in the Zona Pública are subject to an authorization and concession system. For agriculture and fisheries activities, authorization is needed from the Ministry of Agriculture; for clearing activities, a municipal authorization is needed; for housing construction, a municipal permit is needed and the plans are to be approved by the Ministry of Health; for quarries and mining and similar

301 Article 31A(1) of 1988 Amendment Act, Coast Conservation (Amendment), No. 64 of 1988, certified on 17 December 1988, published as supplement to Part II of the Gazette of the Democratic Socialist Republic of Sri Lanka, 23 December 1988.

302 See definition in article 41 of Coast Conservation Act of 1981, as amended by the Act of 1988; the latter Act on Coast Conservation, Act No. 57 of 1981, was certified on 9 September, 1981 and published as supplement to Part II of the Gazette of the Democratic Socialist Republic of Sri Lanka of 11 September 1981.

303 See article 31F, of the Coast Conservation Amendment Act No. 64 of 1988. 
extractive activities, an authorization of the Ministry of Economy, Industry and Commerce is needed ${ }^{304}$. In general, requests for these authorizations will have to be submitted through the ICT, which has overall authority over the ZMT. In addition, activities are subject to a concession system, depending on whether taking place in a zone designated by ICT as zona turistica or zona non-turistica. The concession fees are set by the law under a scheme which allows reassessment every five years. The revenues from the permits accrue to the municipalities which must allocate 20 percent to compensation schemes and 40 percent to improving the ZMT infrastructure ${ }^{305}$.

\subsection{Environmental Assessment Procedures}

Environmental assessment procedures, particularly environmental impact assessments of proposed projects (EIAs), are one of the most important techniques in ICM legislation and are an essential component of any comprehensive system of coastal management. EIAs and strategic environmental assessments of programmes, policies and plans (SEAs), are particularly useful in the ICM context because it is inherently preventive in nature and is specifically concerned with evaluating the linkages between human activities and the natural environment.

It is important to distinguish at the outset between:

(a) assessing the environmental impact of proposed projects and activities (the most common form of EIA procedure);

(b) assessing the environmental impacts of existing undertakings or activities (often referred to as "environmental auditing"); and

(c) assessing the environmental impact of proposed policies, programmes, plans or even legislation (usually referred to as "strategic environmental assessment" or "SEA").

Reference is also sometimes made to cumulative environmental assessment (CEA) which refers to the assessment of the cumulative impact of a number of different activities within a defined area. This approach is particularly appropriate in the context of integrated coastal management since coastal

304 ZMT decree, article 3.

305 ZMT law, article 59. 
degradation is often caused by the cumulative impact of many separate activities which may be dispersed over a wide area. This usually occurs because the rivers carry sediment and pollution from vast catchment areas into estuaries and coastal waters, where they may accumulate. Similarly, uncontrolled construction along the coast may cause considerable coastal degradation, even though no single project or building may have been particularly harmful if considered in isolation. Cumulative environmental impact is not dealt with separately here, as in practice the consideration of cumulative impacts tends to be integrated into one or more of the other approaches. For example, in coastal areas it would be appropriate to require the cumulative impacts to be considered in EIAs of proposed projects, environmental audits of existing undertakings and in SEAs.

It is important to appreciate that EIA, EA and SEA procedures are all intended to gather relevant information concerning the likely or actual impacts of the project, policy, programme or plan in a manner that allows for public participation, and then to present the information in an appropriate form for consideration by the appropriate decision-maker. In other words, it is a decision-making tool that must be used in conjunction with other legal mechanisms, most commonly a requirement for an authorization to be obtained before a particular activity can be undertaken. In order for these procedures to be effective, they must:

(a) ensure that all relevant information is gathered and analyzed by appropriately qualified persons;

(b) allow for the participation of interested and affected parties;

(c) oblige a competent decision-maker to consider the findings regarding the potential environmental impacts;

(d) require the decision-maker to either refuse the authorization if the reports indicate an unacceptable level of environmental impact, or to grant it subject to conditions that will have the effect of reducing the environmental impacts to an acceptable level;

(e) establish mechanisms for monitoring activities that have been authorized to ensure that the conditions of authorization are being complied with; and

(f) include appropriate enforcement mechanisms so that action is taken if the conditions of authorization are not complied with. 


\subsubsection{EIAs of Proposed Projects}

Many nations have introduced obligatory EIA procedures for proposed activities or projects taking place in the coastal zone. In some cases, EIA procedures are linked with the use of other ICM-related legal mechanisms such as the establishment of coastal protection zones. the result is that even if an EIA report is not ordinarily required for a particular activity, it may be required if that activity is to be undertaken with the coastal zone or a particular part of the coastal zone.

\section{Deciding which activities require EIAs}

One of the most difficult aspects of formulating effective EIA legislation is to cast the legislative net sufficiently wide to capture all activities that pose a significant risk to the environment, while avoiding requiring EIAs for so many relatively insignificant projects that administrative systems are overburdened. Furthermore, taking an overly bureaucratic approach can also hinder even environmentally responsible coastal development.

Most countries address this tension by adopting a dual approach. The first part of this approach involves listing those categories of activities that are assumed to have potentially negative environmental impacts and stipulating that EIAs must be provided when applying for permission to undertake any listed activity. The second aspect involves stipulating that even if a particular activity is not listed, an EIA must still be undertaken if the potential environmental damage exceeds a particular threshold. In some countries, such as Uruguay, a proposed project which does not fall within any of the listed categories may still require an EIA if the activity in question is likely to have a detrimental effect on the environment ${ }^{306}$. In some countries, further refinements to this basic system are introduced by provisions which allow for different categories of listed activities with more onerous procedures applying to those categories of activities which are seen as posing the greatest environmental risk. A particular project may be re-categorized on the basis of an initial study or scoping report.

306 Ley Nº 16-466 de Medio Ambiente, 1994, article 6(M). 
Within the European Union the Environmental Impact Assessment Directive $85 / 337 / \mathrm{EEC}^{307}$ requires the assessment of the potential environmental effects of a range of listed projects, before a decision is taken on whether or not to authorize them. An EIA is mandatory for projects listed in Annex I of the EIA Directive, while projects listed in Annex II add modification to projects listed in Annex I. The EIA is only necessary if the project is likely to have significant environmental effects. Many of the listed projects typically occur within coastal areas. For example, trading ports and wastewater treatment plants with a capacity exceeding 150000 population equivalent, are listed in Annex I. Annex II includes projects such as: intensive fish farming, reclamation of land from the sea, the construction of roads, harbours and port installations, including fishing harbours, where these are not covered by Annex I, and coastal works to combat erosion and maritime works capable of altering the coast through the construction of infrastructures such as dykes and sea defence works. The EIA must cover direct and indirect effects of a project on (1) human beings, fauna and flora, (2) soil, water, air, climate and the landscape, (3) the interaction between the factors mentioned, (4) material assets and the cultural heritage (article 3).

Importantly, the EIA Directive requires that environmental authorities and the public be given an opportunity to participate and comment before development consents are granted. Furthermore, other Member States must also be consulted where their environments are likely to be significantly affected in accordance with the Espoo Convention on Environmental Impact Assessment in the Transboundary Context.

In Indonesia, an environmental impact analysis of the impact on the environment, both physical and non-physical (including socio-cultural impacts) ${ }^{308}$, of any particular programme or project, must be undertaken during the planning stage of the programme or project. The trigger is similar to that of the EC directive: every plan of a business or activity "which would possibly give rise to a large an important impact on the environment" 309 .

307 Official Journal No. L175, 5 July 1985, p. 40.

308 Government Regulation No. 27 of 1999, article 3(1)(d).

309 Law No. 23/1997 on Environmental Management, article 15(1); Act concerning the Basic Provisions for the Management of the Environment (1982), article 15(1); see Government Regulation No. 27 of 1999, article 5. 


\section{Should there be a separate EIA procedure for coastal developments?}

In some countries there is a single EIA procedure which applies to developments throughout the country, whereas other countries have separate, coast-specific EIA procedures. It would appear that neither approach is inherently superior to the other and the most appropriate approach will depend on the circumstances in each country, particularly the nature and capacity of the institutions that will be required to implement the EIA system.

In countries in which there is a unified EIA system, it is nevertheless common to find specific coastal references which have the effect of requiring EIAs in respect of a particular activity only if it is to be situated near the coast or within a particular coastal area such as coastal waters, the foreshore, or within a protected coastal area of some kind.

In Sri Lanka, the granting of coastal permits is coupled with an EIA requirement. The 1981 Coast Conservation Act of Sri Lanka defines Environmental Impact Assessment as: "a written analysis of the predicted environmental consequences of a proposed development activity, and includes a description of the avoidable and unavoidable adverse environmental effects of the proposed development activity, a description of alternatives to the activity which might be less harmful to the environment of the Coastal Zone, together with the reasons why such alternatives were rejected, and a description of any irreversible or irretrievable commitments of resources required by the proposed development activity" 310 .

From the 1990 Coastal Zone Management Plan it appears that an EIA will be required by the CCD when a coastal permit is being applied for in case of development activities which are considered to have significant impacts on the coastal environment ${ }^{311}$. Every application for a coastal permit will be submitted to an initial review and site visit by the CCD staff in order to determine whether an EIA is required. If this is the case, the EIA will be reviewed by the CCD, the Advisory Council and the public. If the CCD considers an EIA not necessary, it will request observations from relevant agencies. The Plan gives general guidelines for the preparation of the EIA,

310 Article 42, 1981 Coast Conservation Act.

3111990 Coastal Zone Management Plan, p. 11. 
which, at a minimum, should comprise the following: description of proposed activity, site description, description of potential impacts, proposed mitigation measures, and additional requirements.

\section{The impacts to be considered}

It is interesting to note that there is evidence of a trend for the EIA approach to be expanded to deal with the assessment of socio-economic impacts and impacts on cultural heritage. For example, in South Africa the original EIA regime established by regulations made under the Environment Conservation Act No. 73 of 1989, was strengthened by the enactment by the National Environmental Management Act 107 of 1998. This established minimum conditions for EIAs, including requirements that the potential impacts, including cumulative effects, on the environment, socio-economic conditions and cultural heritage be evaluated ${ }^{312}$. This was followed by the enactment of the National Heritage Resources Act No. 25 of 1999 which requires the authorities responsible for national heritage to be notified before certain developments are authorized and the potential impacts of the proposed developments on national heritage to be assessed prior to deciding whether or not to authorize the development ${ }^{313}$.

From an ICM perspective, integrating the consideration of cumulative impacts, socio-economic impact and impacts on cultural heritage into decision-making processes relating to the use of the coastal zone is to be welcomed. This reflects recognition of coastal management as a process requiring interaction between human activities and the natural environment which should be understood as part of a wider system rather than being considered as separate components. The integration of cultural heritage considerations is also appropriate given the fact that many coastal areas contain an unusually high proportion of cultural artefacts (e.g. the ruins of ancient cities and shipwrecks) and of natural features and landscapes which have great cultural or religious significance. The protection of cultural heritage can also be useful in conveying to the public the importance of coastal areas to humanity throughout time, and of the need to consider future generations and to take a long-term approach to coastal management.

312 National Environmental Management Act, No. 107 of 1998, section 27(7)(b).

313 National Heritage Resources Act, No. 25 of 1999, section 38. 


\subsubsection{New Challenges for Coastal EIA Systems}

The growth of aquaculture in coastal areas in many parts of the world has created new challenges for coastal managers. One of the interesting aspects of aquaculture development from an ICM perspective is that it highlights many of the key issues which ICM seeks to address and provides a clear illustration of the importance of dealing with these issues in an integrated manner. Aquaculture is highly dependent on environmental quality and even a temporary deterioration in water quality can have severe impacts. The location of aquaculture operations is also critical. Many forms of mariculture and aquaculture can only occur in a few locations within the coastal zone, for which there may be intense competition from other users. Furthermore, for aquaculture to develop and flourish, investors usually require a reasonable degree of assurance that if they establish a facility at a particular site, the authorities will take the necessary measures to guarantee the environmental quality of the site. From a government's perspective, this may require long term planning to ensure that conflicts do not arise with other coastal users (e.g. no authorizations should be given for industries that will pollute the waters where the aquaculture is taking place) and the ability to exercise strict control over anyone causing environmental degradation in the area.

For these reasons, there is growing support for the idea of actively integrating the aquaculture sector into coastal area management ${ }^{314}$. In Belize the Coastal Zone Management Act, 1998, provides for the formulation of a coastal zone management plan that must include proposals for the reservation of land or water in the coastal zone for certain uses, or for the prohibition of certain activities in certain areas in the coastal zone, and for the monitoring of the environment, natural resources and various activities, including aquaculture ${ }^{315}$. The Philippines Fisheries Code of 1998 provides that it is state policy to "manage fisheries and aquatic resources, in a manner consistent with the concept of an integrated coastal area management in specific natural fishery management areas, appropriately reported by research, technical services and guidance provided by the state".

In many countries, an EIA is a precondition for obtaining an authorization to undertake aquaculture in coastal areas. For example, EIAs must be

314 See FAO Legislative Study No. 73, 2002, p. 189.

315 Rev. Laws, Cap. 329, section 23. 
undertaken as part of the process for obtaining an aquaculture authorization in the European Union, the Gambia (under the 1994 National Environmental Act), the Seychelles (under the 1994 Environment Protection Act); Mozambique (the 1997 Environment Protection Act); Sri Lanka (1996 Aquaculture Management Regulations as read with the National Environment Act); and Mauritius (1998 Fisheries and Marine Resources Act).

\section{Box 18}

EXAMPLES OF COASTAL ACTIVITIES IN RESPECT OF WHICH EIAS ARE REQUIRED

\section{Belize}

(Environmental Impact Assessment Regulations, 1995, made under the Environmental Protection Act, cap. 328 Rev. Laws.)

Full EIAs are mandatory for: major water works, dams, impoundments and alterations of river banks and shoreline, the construction of hospitals with outfalls into beachfronts used for recreational purposes (regulation 7 as read with Schedule I).

The following projects may require an EIA, depending on the location and size of the project: coastal reclamation involving an area of more than ten acres; the construction of fishing harbours, harbour expansions, land-based aquaculture projects accompanied by the clearing of mangrove forests and all large-scale aquaculture projects; the construction of coastal resort facilities or hotels; the development of tourist or recreational facilities on small islands; aquaculture activities; the reclamation of land from the sea; the construction of roads and harbours, canalization or flood relief works, yacht marina (regulation 8 as read with Schedule II).

Furthermore, the guidelines contained in Schedule II indicate that all applications for building in coastal areas should be referred to the Department to determine whether or not an EIA should be done in accordance with regulation 8 .

\subsubsection{Environmental Auditing of Existing Undertakings}

Assessing the environmental impacts of an existing operation in the coastal zone is no different in principle from assessing the impacts of an undertaking situated elsewhere. Consequently, any such provisions are usually included in general environmental legislation rather than in coastspecific legislation. However, if regulatory authorities do have the power to order an existing business to undertake a full assessment of the environmental impacts of the activities and then impose conditions on the future operations of that undertaking, this can be a powerful tool for ICM. 
Such provisions are particularly valuable in situations in which coastal environments are already degraded and the management challenge is to rehabilitate or restore them. Such powers can also be used as a useful means of gathering information on cumulative environmental impacts in a particular area in order to inform future ICM programmes.

\subsubsection{Strategic Environmental Assessment}

During the 1990s there was increasing recognition of the fact that one of the major causes of environmental harm in some cases was not any specific development project, but rather a public sector programme, policy or plan which encouraged environmentally harmful behaviour. Furthermore, different government ministries formulated plans for their sectors without necessarily considering the environmental implications of doing so. Consequently, it was recognized that it was important to evaluate consciously not only the financial or social implications of adopting a particular policy, plan or programme but also the environmental implications. This led to the birth of the strategic environmental assessment concept, which is usually applied only to defined categories of public programmes, policies and plans. Unlike EIA processes, which involve the site-specific evaluation of potential impacts based on reasonably detailed knowledge of the nature of the proposed development, SEAs require a more abstract assessment of the changes in human behaviour that the programme, policy or plan is likely to result in, and the environmental consequences of those, wherever they may occur.

In a sense, formulating an integrated coastal management plan which has environmental objectives, fulfils a similar function to an SEA in that it specifically addresses the environmental consequences of a range of human activities taking place within the coastal zone. However, from an ICM perspective, it is particularly important to ensure that coastal concerns are taken into account when other noncoastal programmes, policies and plans are being prepared. One of the ways of doing this is by ensuring that any legislation or administrative directive which requires the preparation of a strategic environmental assessment report indicates that the report should address the implications (if any) of the proposed policy, programme or plan for the coastal environment in general, and for the attainment of coastal management objectives in particular. In other words, SEA can be a useful tool for integrating coastal concerns into national development planning as a whole, which is essential since many of the impacts on the coastal zone originate from human activities that lie beyond the boundaries of the coastal area. 


\section{TECHNIQUES FOR PROMOTING THE SUSTAINABLE USE OF COASTAL RESOURCES}

\subsection{Introduction}

This Chapter focuses on the legal techniques that can be used to achieve the sustainable use of coastal resources. Many of these techniques are not specific to coastal management and are commonly used to regulate access to, and the use of, natural resources wherever they occur. Where this is the case, the technique will be dealt with relatively briefly and the focus will be on illustrating its relevance to coastal management and any adaptations that may be required to make it more effective in this context. The discussion of these techniques is also confined to the main regulatory tools and does not discuss the finer details of specialist management areas such as marine capture fisheries.

It is important to be aware from the outset that much ICM literature and legislation is based on the assumption that the primary role of humans in general and the public sector in particular, within coastal areas, is to manage a collection of resources in such a way that the economic and social benefits to humans are optimized. The danger in unquestioningly adopting such a strictly utilitarian approach is that it often obscures the reality that we humans are in fact part of, and dependent on, the natural environment, including the coastal environment. As we are part of the system, human wellbeing is dependent on the health of the system as a whole, and in the long term cannot be achieved except by ensuring that the system as a whole remains healthy. Furthermore, a mechanistic understanding of a coastal environment is both inaccurate and dangerous. The coastal environment is far too complex to be fully understood by human management systems and is shaped by natural forces beyond our control. This is not merely a philosophical quibble since this kind of misperception has led to a range of disastrous interventions. They range from the construction of costly sea defences designed to resist rather than work with the power of the sea, or the catastrophic over-exploitation of fisheries due to a misplaced faith in human abilities to accurately predict natural fluctuations in fish populations.

As mentioned in chapter 1 , even though much of the language of ICM revolves around references to the management of natural resources, the real focus must be on the governance of human activities within the coastal area. One of the key goals of such governance must be to govern humans in such 
a way that we work with rather than against natural forces and recognize that it is also important for humans to play a productive rather than a destructive role within coastal eco-systems.

The concept of "sustainability" also merits further scrutiny. As discussed in chapter 2, the international concept of "sustainable development" is notoriously imprecise and there are a wide range of views on what it actually means. For the purposes of national legislation it is more often referred to as an objective and other more precise legal terms have been developed in an attempt to formulate a concept which is precise enough to be enforced by the courts.

For example, Australia uses the concept of "ecologically sustainable development"316. The Coastal Protection and Management Act of Queensland, Australia, builds on this by defining "coastal management" as including "the protection, conservation, rehabilitation, management and ecologically sustainable development of the coastal zone"317.

Similarly, the New Zealand Resource Management Act states that the purpose of the Act is to promote the sustainable management of natural and physical resources (emphasis added). It then defines the term "sustainable management" to mean:

"managing the use, development, and protection of natural and physical resources in a way, or at a rate, which enables people and communities to provide for their social, economic, and cultural wellbeing and for their health and safety while -

(a) sustaining the potential of natural and physical resources (excluding minerals) to meet the reasonably foreseeable needs of future generations; and

(b) safeguarding the life-supporting capacity of air, water, soil and ecosystems; and

(c) avoiding, remedying, or mitigating any adverse effects on the environment"318.

316 Natural Heritage Trust of Australia Act, 1997, section 21 note (referring to 1992 decision of the Council of Australian Governments); Environmental Protection and Biodiversity Conservation Act, 1999, section 3A.

317 Coastal Protection and Management Act, 1995, section 11.

318 Resource Management Act, 1991, section 5. 
Many of the legal techniques discussed in Chapter 8 (Preserving the coast as public heritage) also play a role in achieving the complementary objective of ensuring that humans use coastal resources in a manner that is ecologically sustainable. In particular, the reinforcement or establishment of a public duty to act responsibly in relation to the coastal environment (discussed in section 8.2) and the defining of environmental quality objectives can play an important role in ensuring that coastal resources are used in a sustainable manner. The use of appropriate principles (discussed in Chapter 2) to guide planning and decision-making in relation to the use of coastal resources is also an important tool.

The primary legislative tools used to regulate the use of coastal resources can be categorized as:
(a) planning tools;
(b) authorization systems; and
(c) economic instruments such as resource user charges.

\subsection{Planning Instruments for Coastal Resource Management}

The main planning instrument for achieving the ecologically sustainable use of resources is the coastal management programme or plan (CMP) itself. Typically, the legislation that mandates the preparation of CMPs will require the programme or plan to address the issue of how to ensure that the use of coastal resources is sustainable. For example, in Barbados the Coastal Zone Management Act stipulates that the coastal zone management plan must "comprise policies, strategies and standards that provide for the management and conservation of coastal resources"319.

Similarly, the Queensland Coastal Protection and Management Act stipulates that state and regional coastal management plans must identify key coastal sites and coastal resources and plan for their long term protection and management ${ }^{320}$.

319 Coastal Zone Management Act, 1998, section 4.

320 Coastal Protection and Management Act, 1995, section 4. 
One of the challenges facing designers of ICM legislation is how to translate resource management objectives in a CMP into legally enforceable provisions. One of the ways in which this can be done is by using local CMPs to translate general resource management objectives into specific coastal management objectives or environmental quality standards for that particular area. A duty can then be imposed on a public body to take all necessary measures to ensure that the specified coastal management objectives are met.

Another useful technique is to require any public body issuing an authorization under any law for an activity which may impact on the attainment of a coastal management objective to refuse to authorize the activity if it would prejudice the attainment of the objective, or to authorize it subject to whatever conditions may be necessary to ensure that the coastal management objective is not compromised. In this way, the proactive planning inherent in developing the CMP (e.g. determining the maximum acceptable level of a particular pollutant in coastal waters) can be used to guide the exercise of administrative discretion in the granting of coastal authorizations so that the cumulative impact of many diverse activities can be managed in an integrated and coordinated manner than furthers the attainment of the overall goals of the ICM programme. (However, it should be borne in mind that the effectiveness of such an approach depends on the existence of an effective monitoring system to ascertain the extent to which the defined environmental quality objectives or coastal management objectives are being met.)

\subsection{Authorization Systems}

\subsubsection{Rationale for Authorization Systems}

One of the most familiar roles of legislation is to establish authorization systems to provide a mechanism for controlling human activities that may have socially or environmentally undesirable consequences. In the context of coastal management, the need to regulate the use of resources may arise in several ways. For example: where there is a demand to exploit a finite resource such as a mineral deposit; where the demand for a renewable natural resource like fish is so great that if unchecked the rate of harvesting will exceed the natural capacity of the population to maintain itself; or if some human activity is resulting in environmental pollution (either alone or in conjunction with other similar activities). 
In cases where the harm or risk of harm from a particular activity is considered to outweigh the social benefits of that activity, or where there are more acceptable alternative ways of achieving the same socially desirable goal, it may be appropriate to prohibit the activity entirely. For example, the London Dumping Convention prohibits the incineration of waste at sea as well as the deliberate dumping at sea of a range of listed pollutants and other wastes. Most countries that are party to that Convention have enacted provisions in their national laws to give effect to these prohibitions.

Authorization regimes are usually introduced where a particular activity (e.g. mining) is considered to be socially useful but to have undesirable consequences if the scale, frequency or manner of undertaking the activity in question is not limited. In these cases governments typically use legislation to prohibit the activity from being undertaken unless it is authorized by a permit, licence or other authorization and is conducted in accordance with the terms and conditions of that authorization. Most, if not all, countries have legislation which requires authorizations to be obtained for a range of activities related to the use of resources in coastal and other areas. These typically include requirements to obtain: fishing licences; aquaculture permits; leases to use coastal commons (e.g. the foreshore or offshore areas); mining licences; permissions for building and infrastructural development; permits to use vehicles on beaches, etc.

Coastal areas are typified by a coincidence of intense and diverse human usage of coastal areas which include particularly ecologically valuable areas, and the variety of different organs of state that have jurisdiction over aspects of these activities. In situations in which coastal management is not integrated, this usually means that a great number of authorizations must be obtained in order to undertake any significant new development in the coastal zone. Indeed it was frustration with the great number and variety of authorizations that had to be obtained in the Baltimore Harbour area of the USA which first led to early attempts at integrated management, and eventually to the ICM approach.

\subsubsection{Integrated Authorization Systems}

The key challenge facing legislative drafters who wish to establish authorization systems for the use of coastal resources within the wider context of ICM, is how to achieve an integrated approach to licensing. It is widely acknowledged that an integrated approach to licensing is desirable. It 
is likely to be less time-consuming, cheaper and more efficient for a coastal resource user to obtain fewer (or a single) authorizations to undertake an activity or to use resources in the coastal area, than to apply for many different authorizations from different agencies. Importantly, a single or integrated application process is likely to give coastal users greater certainty. The risks of different agencies' each with its own requirements, imposing contradictory requirements or making decisions that are at odds with one another will be reduced or eliminated and decision-making is likely to be more consistent, and hence predictable, in the long run.

From the state's perspective, it is desirable that all relevant factors be considered simultaneously when deciding whether or not a particular activity should be allowed to proceed. The potential for inter-agency conflict or litigation by disappointed applicants is likely to be reduced if all the relevant authorities are involved in a single decision-making process, and debate the issues among themselves before arriving at a decision. Integrated procedure should therefore produce a better quality of decision and also more comprehensive and mutually consistent conditions for any authorization. Perhaps most importantly, it is far easier to ensure that implementation of an ICM programme occurs consistently and in a manner that prioritizes the goals of the programme rather than sectoral goals of particular agencies, if the key implementation decisions, such as permitting, are taken in an integrated manner.

Another advantage is that it is far easier and cheaper to ensure effective public participation around a single decision (i.e. whether or not a specific development or use of coastal resources should be permitted) than in relation to a number of different decisions, each of which only deal with one aspect of the development. For example, if a new coastal resort is proposed, it makes little sense to the public to comment separately on issues such as whether or not there is sufficient water for the development, whether the site chosen is appropriate from a land-use planning perspective, whether the impacts on biodiversity are acceptable and whether it is appropriate for the developer in question to be given the necessary trading authorizations.

Despite the attractiveness of establishing integrated permitting systems, there are relatively few examples of well functioning systems. One of the reasons for this appears to be the difficulties in overcoming the inertia within governments that have long established sectoral permitting systems. From a perspective of an official within a particular government department it may seem like a 
retrogressive step to introduce a new integrated permitting system. Indeed, from the perspective of a decision-maker who previously made decisions within a sectoral context, the decision-making process may well be lengthened and become more complex as a result of the introduction of integrated permitting procedures. Instead of having to make narrow decisions (e.g. on the issuing of a licence to discharge effluent into a river) with reference only to well-known departmental guidelines, the official may now be obliged to consult with and meet a range of other parties, which may be time consuming. Furthermore, decision-making is likely to involve balancing a far greater range of interests and taking account of more criteria and principles. However, if the system is well designed, it should be considerably more user-friendly for the coastal user, and the total time taken to obtain all the necessary authorizations should be reduced. In short, if the new procedure replaces five different authorizations with a single integrated authorization, even if the time and effort involved in issuing that single authorization is considerably more than was required to issue any one of the previous five authorizations, the total expenditure of time and effort is still likely to be considerably less.

In order to establish integrated permitting systems it is necessary to identify a particular agency that will take the lead in each case (different agencies can be the lead agency in respect of different types of application) and to either co-ordinate existing authorization processes or abolish them and establish a new process. One of the difficulties commonly encountered in this regard is that the powers necessary to issue and enforce different authorizations are typically contained in different legislation (e.g. water permits may be issued under a water act, environmental authorizations under an environmental management act and waste management permits under local government legislation. This can be addressed in a number of ways, two of which are suggested below.

Firstly, new ICM legislation can be introduced which provides that a single agency may issue an integrated permit covering a range of issues, provided that each of the relevant sectoral agencies were involved in the decisionmaking process, and that enforcement powers in respect of the integrated permit may be given simultaneously to a number of agencies. In other words, officials from various different agencies may be empowered to enforce the conditions of the authorization, either using powers under new ICM legislation or granted under separate sectoral laws, but in practice each would tend to enforce only those conditions which were relevant to their ordinary area of jurisdiction. In other words, even though a single integrated permit might contain conditions dealing with discharges of effluent into fresh water 
and conditions relating to the preservation of indigenous vegetation, the former might be enforced by the agency responsible for managing water resources and the latter by a different agency responsible for the conservation of biological diversity. However, care must be taken to ensure that the legislation under which the integrated permits are issued is sufficiently broad in scope to enable permits covering a range of issues to be validly issued under it, and that all officials responsible for enforcing those conditions have the necessary legislative powers to do so.

Another way of approaching this issue is to provide an inter-agency forum where all the relevant issues can be discussed and a joint decision can be taken as to whether or not to authorize the development, and if so, the conditions that are to apply. Once this has been done, separate authorizations can be issued simultaneously using existing powers under the different sectoral legislation. In other words, one could still have a single application form and procedure, followed by inter-agency decision-making involving all relevant regulatory authorities, but multiple authorizations would still be issued, the main difference being that they should all be consistent with one another, and read together should have the same legal effect as a single integrated authorization.

Both of these options will require careful thought and legal analysis if they are to be effectively implemented. Legal issues such as how to provide for effective means of appeal against conditions imposed will have to be considered and overcome. Administrative procedures will have to be coordinated and harmonized and new protocols to guide inter-agency decisionmaking established, and new application forms and guidelines prepared. Despite the time and effort required to effect the transition, a properly designed integrated permitting system should yield significant dividends in terms of improved decision-making (and consequently less unforeseen wastage of, or damage to coastal resources) and increased efficiency, predictability and cost effectiveness.

\subsection{Economic Instruments for Sustainable Use}

Economic instruments such as charges for public resource use are powerful means of ensuring sustainable use, especially in conjunction with planning and authorization systems. Purely economic systems have the defect noted above that they tend to overvalue private profit and undervalue both future values and public benefit. Planning and authorization by themselves often lead to 
impossible decisional conflicts among roughly equally qualified candidates for the use of extremely valuable resources. When these are given away for free, there is an inevitably irrational quality to the process since there is at least the appearance that the successful candidate is getting something for nothing.

User charges cover a great range from simple licence fees and royalty payments to complex concession arrangements where fees are based on the land or sea area, the use made, the resources extracted and market and profit trends. There are entire libraries dedicated to forest fees, land taxation, fishing fees, mining royalties and development levies, all of which may be relevant to sustainable use of the coastal zone. It is not possible to go into detail about these, but some general points can be made.

In the ICM perspective, a fee that limits access to the coastal zone and its resources tends to reduce the pressure to over-exploit the zone. To contribute to integrated management, fees need to be structured with greater subtlety than simply to maximize revenue. Incentives to longer-term, stable and multiple uses need to be incorporated, which usually means that the level cannot be so high that it forces some users out or forces others to take wasteful, short-term practices in order to avoid bankruptcy. In the case of renewable resources such as mangroves and fisheries, the effect of fees needs to be carefully monitored to prevent distortions such as local overcutting or excessive by-catch. In general, care needs to be taken not to place excess emphasis on the advance payment element of fees, as that tends to encourage more rapid utilization than higher royalties or periodic payments.

The focus on economic instruments cannot be limited to fees, as property, sales and income taxes may have a greater weight on the resource user. There are endless examples of taxes and tax exemptions designed to achieve environmental and development goals. An obvious one is tax deductions for the cost of forest plantations. Because of the complexity of the coastal environment, the effect of the different tax and user-charge regimes is especially difficult to analyse but also especially important. For a brief summary of the complexity of the tax and incentive issues, see "Stewardship Incentives for Louisiana's Coastal Landowners"321.

321 Caffrey, R.H., Savoie, K. and Shirley, M. 2003. Stewardship Incentives for Louisiana's Coastal Landowners, Interpretative Topic Series on Coastal Wetland Restoration in Louisiana. 


\section{ENSURING COMPLIANCE}

\subsection{Introduction}

The best-drafted ICM law will have little effect in advancing ICM if it is not complied with. All too often compliance is seen as an issue to be dealt with by inspectors and other enforcement officers after the legislation has been drafted, enacted and brought into force. In fact the degree of compliance that is achieved can be affected significantly by the process used to develop the legislation and by the design of the legislation itself. These factors will also have an important impact on the amount of money and effort that will be required to implement the law. For example, if a legal rule is perceived as being unfair, and it is difficult or expensive to comply with it, one would anticipate a high degree of non-compliance unless very significant effort and money were expended to enforce the legislation. This means that it is wise to consider ways of improving compliance throughout the legislative reform process.

\subsection{Factors Affecting Compliance}

How a law functions is determined by the legal, political and socio-economic context in which it exists. There are many factors that affect levels of compliance and hence the effectiveness of legislation, and consequently it is impossible to develop an accurate formula for predicting the level of compliance that is likely to be achieved. However, an understanding of the inter-relationship between the key factors that influence compliance levels is helpful when designing or implementing a new law, or planning a strategy to improve compliance with an existing law.

In general terms, the degree of compliance with the legal rule will be affected by:

(a) the proportion of those affected who know about the rule;

(b) the incentives that they have to comply with the rule;

(c) the risks of non-compliance, and

(d) the disincentives to comply.

The relationship between these factors is illustrated graphically in the diagram in Box 19. As the diagram illustrates, one would expect the majority of people affected by a particular rule to comply with it if, in their perception, their incentives to comply with the rule (A), when taken together 
with the perceived legal, economic and social risks to them of not complying (B), exceeds what they understand to be their disincentives to complying.

Box 19

FACTORS AFFECTING COMPLIANCE WITH LAWS
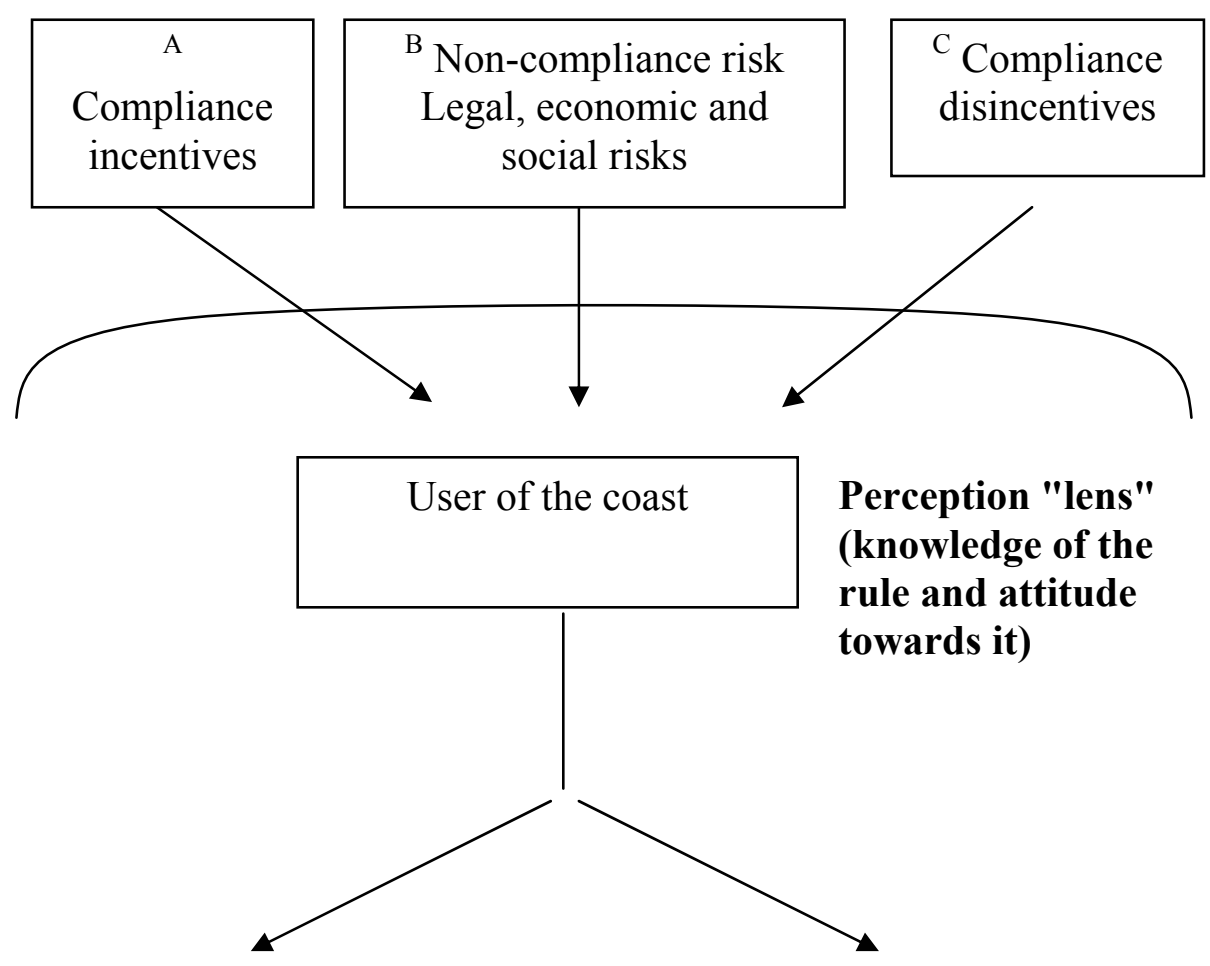

Perception "lens"

(knowledge of the

rule and attitude

towards it)

Non-compliance

(if $\mathbf{C}>\mathbf{A}+\mathbf{B})$
Compliance (if $\mathbf{A}+\mathbf{B}>\mathbf{C}$ )

The perception lens in the diagram indicates that the people affected by the rule (in this case, users of the coast) do not respond to the rule itself, but rather to a subjective view of the rule. Obviously only those who know about the rule are likely to consciously try to adapt their behaviour to comply with it or to circumvent it, so the lens and so the incentives and disincentives will only be relevant to this group. The attitude of those coastal user who know that 
the rule exists (particularly the extent to which they regard the rule as appropriate and fair), will also have a significant effect on how they respond to the other factors. If more of the group believe that the law should be complied with, this is likely to have a significant effect on compliance levels. This implies that measures to improve stakeholders' knowledge about the law, and to increase its legitimacy in their eyes (e.g. by involving stakeholders in the process of preparing the law) are like to significantly increase compliance levels.

Compliance incentives include all economic and other benefits to be gained by compliance. These may include access to natural resources and increased security.

Non-compliance risk means the total legal, economic and social risks to those affected if they do not comply. For example, the risks to a company that does not comply with a condition in a permit issued to it, may include: (i) being prosecuted and fined, (ii) being temporarily prevented from operating thereby causing significant economic losses, and (iii) damage the company's reputation. These risks are often related and the higher the total risk the more likely it is that those affected will comply.

Legal risk, in general terms, can be regarded as a risk of being punished (i.e. the probability of being caught and convicted of breaking a rule) multiplied by the penalty. One of the ways of increasing compliance is therefore to increase the legal risk. This can usually be done by increasing enforcement actions (e.g. the number and frequency of inspections, on the spot fines, and prosecutions) and by increasing the penalties or other sanctions. Innovative enforcement measures can sometimes be used to increase the legal risk but in many cases it will be necessary to spend more on enforcement in order to increase legal risk.

Economic risk is the risk of economic loss other than by fines or the like. For example, if non-compliance affects the reputation of the market participant it could result in economic losses in the long term.

Social risk is the risk that non-compliance would cause adverse social effects for the person in question. In the case of individuals, the fear of social rejection as a result of non-compliance with socially acceptable standards of behaviour can be a powerful factor inducing compliance. 
Compliance disincentives consist mainly of compliance costs. These include actual disbursements such as application fees, as well as the disincentive effect of having to spend considerable time and effort negotiating the intricacies of complex bureaucratic processes. This is a particular danger in ICM where the aims of legislation are particularly complex and in some cases contradictory. If this factor is sufficiently high it will outweigh the combined effects of the compliance incentives and the non-compliance risk, with the result that stakeholders are more likely to contravene the law than to comply with it. Reducing these disincentives will therefore increase the prospects of compliance.

\subsection{How to Increase Compliance}

Theoretically then, compliance levels can be increased by a combination of increasing knowledge about the relevant rule and stakeholder approval of it; increasing compliance incentives and the risk of non-compliance; and reducing disincentives to compliance.

\subsubsection{Changing Perceptions of the Law}

More positive perceptions regarding new legislation can be created by:

- involving stakeholders in the preparation of legislation;

- drafting clear laws that can be understood by lay people;

- increasing transparency by establishing clear criteria to guide the exercise of administrative discretion and providing rights of appeal in appropriate circumstances;

- ensuring that changes in the law are communicated clearly to all affected parties well before they are brought into effect; and

- ensuring that the implementation and enforcement of the law is consistent.

\subsubsection{Increasing Legal Risk}

Legislation can also be used to increase legal risk (and hence the risk of noncompliance) by increasing sanctions and penalties and by establishing effective enforcement mechanisms (e.g. by providing for the use of administrative orders). 


\section{Increasing the sanctions}

The Environmental Protection Act of Belize contains a number of provisions designed to increase the risk of non-compliance. In addition to the conventional fines and imprisonment which may be imposed for various offences under the Act, the court is given a wide discretion to make an order directing the offender:

(a) to refrain from doing anything that may result in the continuation, or a repetition, of the offence;

(b) to take appropriate action to remedy or avoid harm to the environment that results or may result from the offence;

(c) to publish facts relating to the conviction and to notify any person aggrieved or affected by the offence;

(d) to post a bond or pay an amount of money into court to ensure compliance with the order;

(e) to submit further information about its activities;

(f) to compensate the state, for the costs of any remedial or preventative action taken as a result of the offence;

(g) to perform community service;

(h) to comply with any other reasonable conditions which the court considers appropriate and just for securing the offender's good conduct and preventing the repetition of the offence by the offender ${ }^{322}$.

The court may also order an offender to pay an additional fine equivalent to the court's estimation of any monetary benefit that the offender may have acquired as a result of the commission of the offence ${ }^{323}$. Furthermore, if a person aggrieved by the offence, makes an appropriate application to the court, the court may order the offender to pay that person an amount by way of satisfaction or compensation for loss of, or damage to, property suffered by the person as a result of the commission of the offence ${ }^{324}$. Furthermore, if

322 Environmental Protection Act, Cap. 328, section 34.

323 Ibid., section 35.

324 Ibid., section 36. 
a person has suffered loss or damage as a result of any conduct that is contrary to the Act or Regulations, that person may recover from the responsible party an amount equal to the loss or damage suffered and an amount to compensate for the cost of any investigation of the matter and of the court proceedings. The injured party may also seek an injunction from the Supreme Court to prevent anyone causing loss or damage as a result of conduct contrary to the Act.

\section{Facilitating enforcement}

Another way of increasing legal risk and thereby compliance with ICM legislation is to make it easier and cheaper for the authorities to enforce the legislation. One of the ways of doing this is to empower the authorities to issue and enforce administrative orders without having to incur the high costs and long delays usually associated with court proceedings.

In the Australian state of Queensland, the Coastal Protection and Management Act empowers the Chief Executive to give several different kinds of notices and provides that any person to whom such a notice is addressed and who fails to comply with it, is liable to pay a penalty. For example, the Chief Executive can issue a coastal protection notice directing a person to take reasonable action stated in the notice to protect land, or to stop or refrain from starting an activity. Such a notice can be used, for example, to require a person to build or maintain structures or other works, to preserve indigenous vegetation, to refrain from altering the geographical features of land, or to restore land ${ }^{325}$. The Chief Executive may also give a tidal works notice requiring a person responsible for the works to repair it, or to remove it and restore the site as near as practicable to its former condition $^{326}$. Furthermore, if a person fails to comply with the coastal protection or tidal works notice the Chief Executive may take the required action and recover the cost and expenses reasonably incurred from the person to whom the notice was directed. If a coastal protection or tidal works notice is served on both the owner of the land and the person responsible for the works they are jointly and severally bound by the requirements of the notice. (The term "owner of land" includes the occupier of land.) Furthermore, if the owner of land or works in respect of which

325 Coastal Protection and Management Act, 1995, section 52.

326 Ibid., section 53. 
such a notice has been issued but not yet complied with, wishes to sell the land, the seller must advise the purchaser in writing about the undischarged notice and the buyer will then be bound by the notice.

\subsubsection{Reducing Disincentives to Compliance}

The disincentives to compliance can also be reduced in a variety of ways, including by:

- improving the communication of the law to those affected by it;

- streamlining bureaucratic processes, for example by reducing the number of authorizations required (particularly where a variety of authorizations have to be obtained from different government bodies);

- publicizing the criteria which will be used in deciding whether or not to grant an authorization; and

- in general, simplifying requirements, procedures and legislation drafting.

Therefore in designing integrated permitting systems it is important to ensure that the end result is to make it easier for applicants (and if possible, quicker and cheaper too) and thereby increase the likelihood of compliance. 


\section{INSTITUTIONAL ASPECTS}

\subsection{The Interdependence of Laws and Institutions}

As discussed in section 1.1, governance is at the heart of ICM. How the coast is governed is largely determined by the inter-relationship between coastal policies, programmes and plans, the legal framework within which these CMPs are formulated, and the institutions involved in formulating and implementing CMPs and enforcing the relevant legislation. Laws both shape and are shaped by, institutions. On the one hand, law plays a critical part in constituting public sector institutions and in defining their composition, powers and responsibilities. On the other hand, existing institutions typically play a significant role in shaping the design of any new ICM legislation or the amendment of existing legislation to achieve ICM objectives. Perhaps most importantly, the effect which any law has on the coastal management regime will depend on how, and to what extent, it is implemented. This depends on institutions.

As mentioned in Chapter 4, one of the critical steps in developing ICM legislation is analysing the existing institutional arrangements at the same time as reviewing and analysing the laws. In doing so, it is useful to bear in mind the key functions for which institutions are likely to be required in order to establish a fully functioning ICM governance system. For example, institutional mechanisms are likely to be required to perform most of the following functions:

(a) policy formulation, including mechanisms for formulating, reviewing and revising ICM programmes, for obtain expert advice, and for facilitating the participation of stakeholders in the policy formulation process;

(b) rule making (i.e. a legislative function);

(c) co-ordination of implementation of the CMP;

(d) implementation of the various aspects of the programme (often carried out by a range of different institutions, many of which may be oriented towards a particular sector);

(e) monitoring and reviewing functions to assess the effectiveness of the CMP and to ensure that it is updated and approved over time (this is essential as ICM is an iterative process); 
(f) funding and financial support;

(g) dispute resolution.

\subsection{Moving Towards More Integrated Institutional Arrangements}

The process of moving away from a strongly sectoral approach towards a more integrated institutional structure requires management and sustained effort and is not always successful. This section examines various routes taken by different countries in moving towards greater institutional integration as well as one initiative which resulted in a reversion to the sectoral approach.

Theoretically a country wishing to embark on this process is faced with a number of institutional options including:

- creating a new government agency with jurisdiction over the coastal zone, and with powers to enact, amend and complete a CMP and to prepare legislation;

- setting up an interdepartmental commission or a task force with authority to devise a coastal management plan, issue guidelines for the integration and co-ordination of existing policies and develop appropriate laws;

- appointing a lead agency from among the existing government departments with a mandate to prepare a coastal management plan, and with the power to direct the actions of other government agencies;

- setting up a non-executive advisory committee with members from several agencies and/or interest groups to study coastal issues and to advise the government on how best to address them; and

- setting up a framework for regular interdepartmental consultation, supported if necessary by the signature of a memorandum of understanding.

Sri Lanka and the British Virgin Islands (BVI) are examples of countries that chose to establish an entire new government agency with a broad mandate to develop a national CMP and to devise ICM legislation. The USA and China designated lead agencies while Thailand and the State of Victoria in Australia chose to set up non-executive advisory committees. 


\subsubsection{Creating New Agencies}

Sri Lanka began to move away from the sectoral approach in 1963 when a more comprehensive coastal zone management system was initiated by the establishment of the Sri Lankan Coast Protection Unit. In 1978 a Coast Conservation Division was set up in the Ministry of Fisheries, and upgraded to a Department in 1984. In 1981, the Coast Conservation Act was passed, providing for the establishment of an interdepartmental Coast Conservation Advisory Council. The Act was amended in 1988, and subsequently, a Coastal Zone Management Plan (CZMP) received the assent of the cabinet in 1990. The role of the Advisory Council is to advise the Minster of Ports and Shipping on all development activities in the coastal zone, to review the CZMP prepared by the Coast Conservation Department (CCD), to review certain EIAs, and other pertinent matters related to the coastal zone ${ }^{327}$.

The Sri Lankan CCD is charged with responsibility for coastal protection and coastal zone management. Policy integration is achieved through the mechanism of the CZMP formulated by the CCD. The plan; addresses well defined coastal management issues (coastal erosion, management of coastal habitats, loss and degradation of archaeological, historical, and cultural sites, management of recreational and scenic areas); sets out the regulatory framework for coastal permits; proposes changes to the legislative, administrative and financial framework for the coast; and stresses the need for more research, public awareness and education. An incremental approach has been adopted and it is envisaged that the plan will be modified, refined and developed on the basis of experience.

\subsubsection{Designating Lead Agencies}

Several countries have chosen to designate an existing government agency as the "lead agency" responsible for coastal management instead of establishing a new agency. This option appears is often preferred by countries that have an elaborate administrative system in place with established line agencies each handling a traditional sectoral portfolio. Rather then establishing a new bureaucracy, the legislator opts for devolving the authority for implementing the new coastal zone legislation to the entity that seems best suited for the task in the light of the dominant concerns and the management strategies

3271981 Coast Conservation Act, articles 6 ff. 
chosen in the legislation. For example, in the USA, the National Ocean and Atmospheric Administration (NOAA) was chosen as the lead agency to oversee the Coastal Zone Management Act. The NOAA has specialized offices such as the Office of Protected Species and Habitat Conservation, and the National Marine Fisheries Service.

\subsubsection{Advisory Councils Without Executive Powers (Victoria, Australia and Thailand)}

Although the option of establishing a commission, task force or agency endowed with advisory and policy making powers but without designating a single administration having ultimate jurisdiction over the coastal zone may be attractive to legislators and government agencies anxious to protect their existing roles, it is important to first consider the potential drawbacks. In particular, if there is a division between planning and policy on the one hand and implementation and enforcement on the other hand, good, progressive policies generated by the advisory commission or agency may be nullified by the reluctance of established bureaucracies to change their ways or to give up power.

An illustration of this is the Port Phillip Authority in Victoria, Australia. It was established in 1966 to deal with planning and management of the coastal fringe and nearshore waters of the Port Phillip Bay. An integrated approach was launched through the establishment of the Authority which included representatives of existing management agencies (Ports and Harbours Division, Soil Conservation Authority, Lands Department, Town and Country Planning Board), and through consultation mechanisms with other agencies and public interest groups.

The Authority devised an environmental study and a permit procedure for changes in utilization within its jurisdiction and had the right to consult with hinterland and offshore management agencies over problems such as nearshore pollution from rivers or discharges at sea. From the beginning, however, the Authority suffered from lack of adequate funding and unwillingness of established agencies to give up their decision-making powers to a coastal authority. The Authority was gradually reduced to a permit issuing agency and in 1980 a political decision was taken to disband it. Victoria now reportedly pursues a more divided strategy having assigned coastal management responsibility to a least three different state departments (the Ministry of Planning and Environment, the Department of 
Conservation, the Port of Melbourne Authority), and by encouraging other agencies and coastal municipalities to include coastal issues on their agenda $^{328}$.

Another drawback of making the implementation of ICM dependent on the approval of a non-executive advisory council or agency is that the ensuing planning and implementation process can be significantly slower as the experience of the Thai Office of the National Environment Board (ONEB) demonstrates.

ONEB is a government agency which analyses environmental issues from a broad perspective and makes recommendations to the Cabinet, the Parliament, and the Economic and Social Development. As a result of its work, coastal issues are on the national agenda in Thailand, having been identified since the mid-1970s as an area of concern.

ONEB has devised a national policy encompassing five national priority coastal resource issues in a policy development plan. As ONEB is merely a policy making agency, implementation and enforcement remains with separate state agencies ${ }^{329}$. The results have been mixed, at best, and the disadvantages of this approach are gradually being recognized, since the seventh development plan (1992-1996) emphasizes the need for more interagency collaboration, more participation by local government and nongovernment agencies, more public awareness, and better technical information provision ${ }^{330}$.

\subsection{Formulating the ICM Programme}

In order for coastal management to be integrated, it is essential that all the institutions responsible for managing different activities within the coastal

328 Bird E., 1991. Aspects of Integrated Coastal Zone Management, CAMPNET, p. 69.

329 For instance, the Department of Fisheries responsible for fisheries resources; the Royal Forestry Department responsible for mangrove areas, the Department of Mineral resources for oil and gas exploration and exploitation, the Tourism Authority for tourism policy, the Land Development Department for physical development and settlements. See Monthip Sriratana Tabucanon, 1990, pp. 582 and 583 , who complains that intersectoral cooperation is rarely achieved.

330 Ibid., p. 579. 
zone co-ordinate their activities with reference to a comprehensive, integrated and internally consistent coastal management policy, programme or plan (CMP). This CMP need not necessarily be contained in a single document, for example there may be a national coastal management policy, which is fleshed out in more detailed regional or local CMPs. However, the critical thing is that in any particular area of the coast, the different institutions with executive authority must be executing the same, or at least mutually consistent, plans, policies and programmes. If the system does not ensure that at any given time, all the relevant agencies are seeking to achieve the same set of policy objectives and priorities, integrated management will not result. This does not mean that each agency is required to pursue all the policy objectives, but only that the actions of all must be intended to give effect to the same vision, and that mutually incompatible policy objectives are not pursued.

Formulating a comprehensive, properly integrated CMP requires the involvement of those institutions that will be responsible for implementing it, stakeholders who will be affected by it, and experts who can contribute the necessary specialist knowledge to inform policy decisions. In most countries, this is achieved by giving a particular institution responsibility for formulating the plan or taking the lead in co-ordinating a multi-sectoral group of institutions to formulate the CMP. The other functions of achieving access to expert advice and involving stakeholders, are achieved in a number of ways in different countries. The institution mandated to prepare the CMP can include stakeholder representatives and experts, or may be mandated to consult them in the process of formulating the CMP, or a separate advisory body may be established on which stakeholders and experts are represented. In some countries, such as Belize, research institutes have also been established in order to generate the information required to formulate CMPs and to adapt and refine them over time.

\section{Belize}

In Belize, the Coastal Zone Management Act ${ }^{331}$ establishes a Coastal Zone Management Authority, an Advisory Council and a Coastal Zone Management Institute.

331 Rev. Laws, Cap. 329. 
The Coastal Zone Management Authority ("the Authority") has a number of functions including:

- advisory functions (e.g. it is required to advise the Minister on coastal matters and the formulation of policies and guidelines in relation to the coastal zone);

- executive functions (e.g. it has to assist in the development and implementation of coastal programmes and projects);

- oversight (monitoring and review) functions (e.g. it must review the coastal zone management plan and give recommendations on it to the Minister, and must maintain monitoring programmes in relation to issues such as coral reefs and coastal water quality);

- advocacy functions, for example, by promoting public awareness of the unique nature and importance of the Belize coastal zone.

A nine-member Board of Directors exercises oversight over the Authority. The Board of Directors consists of four permanent secretaries of relevant ministries, the President of the University College of Belize, a representative of NGOs, a representative of the private sector, and the Chief Executive Officer of the Authority and the Director of the Coastal Zone Management Institute (neither of whom has a vote). The Board is run on a day to day basis by the Chief Executive Officer who is answerable to the Board. One of the key tasks of the CEO is to prepare and submit to the Board a comprehensive coastal zone management plan prepared after consultation with all relevant stakeholders. Once approved by the board, the draft plan must be published in the Government Gazette for public comment and thereafter submitted to the Minister responsible for agriculture and fisheries for approval and subsequent tabling in the House of Representatives for approval by affirmative resolution.

The Advisory Council is appointed by the Authority primarily to provide it with the necessary advice to enable it to perform its functions. It must also play a role in formulating draft policies, plans and programmes, facilitating and encouraging the sharing of information among government agencies and other stakeholders, and assist in reviewing the coastal zone management plan.

The Coastal Zone Management Institute is established to stimulate and advance the conduct of marine scientific research and to promote a public understanding of, and appreciation for, the marine related environment. In 
addition to research functions, it must assist in the maintenance of a centre for information and research relating to the coastal zone; support the University and College of Belize, other educational institutions and government and nongovernmental agencies; facilitate the sharing of information on coastal resources among stakeholders; and play a regional role in the research, collection and dissemination of coast-related information.

\section{Barbados}

In Barbados, the Coastal Zone Management Act, 1998, requires the National Conservation Commission ${ }^{332}$ to prepare a draft coastal zone management plan and draft order delimiting a coastal zone management area for presentation to the Minister. The Minister is then required to hold a public inquiry at which these can be discussed. Thereafter the Minister may make appropriate modifications to take account of comments and then by order published in the Official Gazette establish the coastal management plan and coastal management area of Barbados.

In designing institutional mechanisms to produce integrated CMPs, it is important:

- to ensure that sufficient expertise and information will be available to those formulating the CMP;

- to structure the composition of the institutions or the procedures that must be followed in formulating the CMP to ensure that all the key stakeholders are sufficiently involved so that they "buy in" to the CMP and will support it at the implementation stage;

- to give effect to key principles of ICM including principles of effective public participation and the integration of environmental and development concerns;

- to have the necessary expertise within them, or available to them, to enable them to formulate appropriate policy responses, plans and programmes in relation to key coastal issues, including transboundary or global issues; and

332 Established by section 4 of the National Conservation Commission Act of 1982 (CAP. 393). 
- to have appropriate credibility in the eyes of the public in order to increase the legitimacy (and hence, effectiveness) of any CMP that it produces.

\subsection{Legislative (Rule-Making) Functions}

In order to implement a CMP it is necessary to prescribe certain standards of behaviour and norms which coastal users either must, or should, comply with. In most countries, mandatory rules enforceable by the courts must be contained in legislation, such as Acts of Parliament, ministerial regulations or orders, or municipal by-laws. In some countries, the CMP itself may include mandatory rules. For example, the Coastal Protection and Management Act, 1995, of the state of Queensland in Australia, provides for the establishment of a state coastal management plan and regional coastal management plans for particular parts of the coastal zone within the state. Both the state coastal management plan and the regional coastal management plans have the same legal status as regulations and may prescribe sentences and penalties (subject to a prescribed maximum) for contraventions of the plan.

In most countries, the Minister, national or state legislature, or municipal authority is simply empowered to use their existing legislative authority to make binding rules to implement the CMP. In other words, ICM legislation merely extends their existing legislative authority.

From an ICM perspective, prescribing legally enforceable rules by way of legislation is not always the best method of achieving ICM objectives. Legal rules, backed by sanctions, are most effective where it is possible to clearly define the limits of acceptable (or unacceptable) conduct. However, there are many situations in which management authorities may wish to encourage more responsible or appropriate conduct and it may be difficult to draw a clear distinction between exactly which conduct is acceptable and which is not. Furthermore, penalizing conduct that falls just short of a particular standard may undermine an objective of educating coastal users about best practice (for example, in relation to aquaculture) and encouraging them to adopt it voluntarily.

For these reasons, management bodies are often given the power to issue guidelines, codes of conduct or similar documents which recommend the adoption of particular practices without penalizing those who fail to do so. Since these documents do not prescribe legally enforceable standards, it may 
not be necessary for the relevant government agency to have specific legislative authority to issue them. However, there are advantages in providing for guidelines of this nature in legislation. In particular, legislation can be used to create incentives to comply with the guidelines. For example, if users of the coastal zone are required to take "reasonable measures" to ensure that they do not cause environmental damage, the law may provide that the operator of an aquaculture farm who complies with the provisions of official guidelines designed to minimize environmental impacts of aquaculture, will be presumed to have taken the necessary "reasonable measures", unless the contrary is proved. This then creates an incentive for aquaculture operators to comply with the code since doing so will substantially reduce the risk of their being convicted for failing to take adequate measures to protect the environment.

Another way of using legislation to create incentives to comply with voluntary codes of conduct is by providing that compliance with a particular code is a factor that will be taken into account in deciding whether or not to grant a licence or to determine eligibility for state funding.

\subsection{Executive Functions}

The success or otherwise of a CMP depends on the extent to which it is effectively implemented. The institutional arrangements for implementing CMPs are accordingly of central importance. The vast range of activities which occur within the coastal zone and which must be addressed in CMPs, mean that it is virtually inevitable that many different government agencies will be involved in implementation, even if one agency is given responsibility for the core coastal management functions. The implication of this is that institutional arrangements for implementing ICM must include:

- strong mechanisms for sharing information;

- means of co-ordinating action on projects or activities involving more than one agency;

- mechanisms to allow different agencies to negotiate about, and resolve differences of opinion or approach to issues; and

- means of monitoring and reviewing implementation and feeding back the information obtained to implementing agencies to enable them to adjust their conduct accordingly. 
In some circumstances, particularly where ICM is being implemented within a particular area of the coast, it may be most effective to create a new institution that is responsible for developing and implementing all coastal zone initiatives within that area. However, in most situations, the implementation of common ICM goals requires the co-ordination of many sectorally-oriented line ministries or other public sector bodies. This can be a difficult task in practice, as sectoral ministries are often highly protective of their core responsibilities, because these determine their powers, the amount of funding they receive, and ultimately employment opportunities within that organ of government.

In designing institutional mechanisms to ensure integrated implementation of CMPs, it is important to bear in mind that the activities of the various implementing agencies must be co-ordinated vertically, horizontally, and temporally. Vertical co-ordination involves ensuring that the action taken at each levels of government, from national down to local community level, is consistent. Horizontal co-ordination refers to co-ordination across different sectors at the same level within the hierarchy (e.g. local agencies responsible for fisheries, tourism and environmental protection must co-ordinate their activities, as must their counterparts at the national level). Temporal coordination requires ensuring that management interventions by different agencies are phased appropriately to ensure that they are mutually supportive.

In practice, it is important firstly, to mandate a particular state institution to ensure that the activities of other agencies are co-ordinated and to be responsible for improving co-ordination and the effectiveness of implementation, over time; and secondly, to impose a duty on all relevant institutions to co-operate and share information relevant to coastal management. Inevitably establishing a well-functioning system for coordinating the activities of different parts of government will require both a degree of trial and error and strong commitment to a common vision. Strong political support at the highest level is also likely to be necessary to overcome the initial resistance that is typically encountered when officials accustomed to working almost exclusively within their own organization are required to interact with, consult with and negotiate with other authorities. 
PART IV

GLOBAL DEVELOPMENT OF ICM LAW 


\section{CURRENT AND FUTURE TRENDS IN ICM LAW}

\subsection{The Future of ICM Law}

As indicated in the foreword, the field of ICM law has changed dramatically since the publication in 1994 of Legal and Institutional Aspects of Integrated Coastal Area Management and National Legislation. The field has continued to develop rapidly, driven by a number of factors, the most important of which are discussed in this publication and surveyed briefly below. However, despite the development of ICM as a practice, now supported in many countries by legislation, from a global perspective it has not yet had a sufficient impact to halt or reverse the deterioration of coastal areas. The urgency of establishing effective regulatory frameworks for ICM becomes even more important when one considers the observations in the Global Environment Outlook 3 (GEO-3) 333 which draws attention to the time lag between the changes in policies and observable impacts on the environment. In fact, it points out that most of the anticipated changes in the global environment over the next 30 years will be primarily determined by policy decisions that have already been taken.

Some of the key factors driving change are set out below.

\subsubsection{Continuing Deterioration of Coastal Environments}

The deterioration in the environmental quality of most coastal areas combined with the failure of the sectoral management approach to stem this destruction is probably the most powerful and obvious factor driving the introduction of ICM (see the foreword and section 1.5.). The main pressures on coastal environments are discussed in section 1.5.3.

\subsubsection{Emergence of New Challenges}

New challenges, such a threats posed by invasive alien species introduced via ships' ballast water, the reality of global sea level rise, and the rapid growth of the aquaculture sector, have exposed inadequacies in current governance systems. In each case, these new challenges have highlighted the importance

333 UNEP, 2002. 
of adopting a cross-sectoral, holistic approach to managing marine and coastal environments, that is, the ICM approach.

\subsubsection{International Endorsement of the ICM Approach}

In a 1995 study, Cicin-Sain, Knecht and Fisk compared five different coastal management guidelines and distilled a consensus set of integrated coastal management guidelines (see Box 2). This study indicated that there was consensus that ICM should be guided by the Rio principles. Since the Rio principles were formulated in 1992, the ICM approach has been endorsed by an increasing number of international instruments, particularly so-called "soft law" instruments (see section 3.3 and Annex 2). This virtually universal endorsement of the ICM approach has strengthened considerable over the past decade, has given it a greater legitimacy and has facilitated its uptake at the national level.

\subsubsection{Maturation of ICM as a Discipline}

At the time of the 1994 study, ICM as a discipline was already welldeveloped in countries such as the United States of America, but internationally it was still in its infancy. The field has expanded considerably since then as ICM is introduced in various countries and academic institutions have trained ICM practitioners. The application of the ICM approach in widely different areas and circumstances has also enriched the field. From an international perspective, ICM principles are better articulated and more widely understood than they were twelve years ago. For example, there is now greater recognition of the importance of adopting a mix of management techniques and adjusting these to take account of the diversity of local conditions that exist within coastal areas. In other words, once the principle that coastal areas were sufficiently different from other eco-systems to justify special treatment was accepted, attention shifted to the diversity which existed within coastal areas.

\subsubsection{Endorsement of ICM at the Regional Level}

The endorsement of ICM in a number of international instruments has also influenced its adoption in particular regions, which in turn makes it more likely that it will be adopted at the national level. For example, the European Union has not addressed coastal management until relatively recently, but the adoption of recommendations on integrated coastal management in Europe 
(see Box 4) is already beginning to have an effect at the national level. Perhaps the biggest effect of regional endorsements of the ICM approach is to encourage those countries that have been hesitant about embarking on the institutional and legal changes that will be required to introduce ICM to do so, and to strive to meet "best practice" within the region.

\subsubsection{Information Technology and the Availability of Information}

As discussed in section 7.5, the introduction of new information technologies such as VMS and GIS has expanded the planning, management, monitoring and enforcement capacity of coastal management institutions. These technologies have facilitated the gathering of considerably more data than were available in the past, and the dissemination of data and new ideas about ICM has been greatly facilitated by the internet. The global availability of significantly more information regarding ICM is likely to speed up its introduction and increase the rate of spread of innovative techniques throughout the world.

13.1.7. Maturation of International Law Concerning the Environment

The number of international instruments, both binding treaties and soft law instruments, dealing with the environment has increased exponentially over the past decade. There are now international and regional instruments dealing with most of the key issues of concern to ICM (see Box 5 and Box 6). As the international law system has become more developed, there has been recognition, particularly since the late 1990s, of the need to apply these instruments in a mutually supportive way (i.e. as a system rather than entirely separate instruments). This is reflected, for example, in increased cooperation between the Ramsar Secretariat and the Conference of the Parties of the Convention on Biological Diversity. It is also evident in the adoption and application of common principles and approaches, such as the precautionary principle, in a variety of different contacts (e.g. climate change, the protection of biological diversity and marine fisheries). These core principles and approaches are largely consistent with the ICM approach and as they filter down to the national level, often via different routes, they can be influential in convincing officials in different ministries of the necessity to adopt an integrated approach based on international accepted norms. 
13.1.8. Establishment and Strengthening of National Environmental Laws

In a significant number of the countries surveyed, the most important legal provisions supporting the ICM approach were contained in comprehensive laws designed to protect the environment as a whole and to advance ecologically sustainable development. In other words, in some countries the adoption at the national level of sustainable development or ecologically sustainable development, as an overarching national goal, has played an important role in promoting the integrated management of coastal areas (see, for example, the discussion in section 6.4).

\subsection{International Trends}

\subsubsection{Influence of International Instruments}

International law and non-binding international and regional instruments continue to exert a strong influence on the development of national ICM legislation. The consolidation of support for the ICM approach at the international level has strengthened this trend and it seems likely that the influence of internationally accepted legal principles and ICM management principles will strengthen. This trend is also likely to be fuelled by the increased availability of information.

\subsubsection{Overriding Importance of Maintaining Ecological Integrity}

Although integrated coastal management has always been based on an understanding that coastal areas need to be understood as an integrated whole and managed accordingly, there has been a perceptible shift towards recognizing the fundamental importance of maintaining the ecological integrity of the coast. This is reflected, for example, in the development of the so-called "ecosystem approach" developed by the Conference of the Parties of the Convention on Biological Diversity 334 , which defined twelve complementary and interlinked principles of the eco-system approach and explained the rationale for each (see Annex 1).

These include the principle that "conservation of ecosystem, structure and functioning, in order to maintain ecosystem services, should be a priority

334 See Decision V/6 adopted at the Fifth Conference of the parties, May 2000. 
target of the ecosystem approach" (principle 5) and "ecosystems must be managed within the limits of their functioning" (principle 6). This has fundamental implications for the design of laws for promoting ICM since it means that the main purpose of ICM must be to ensure that humans play a positive role within coastal ecosystems. In other words, legislators need to ensure that practical mechanisms are put in place for curbing human activities that undermine the ecological functioning of coastal ecosystems.

Although this may seem obvious to many people, much of the literature on coastal management still displays a failure to appreciate that the focus of coastal management ought to be on managing people and their impacts on the coastal environment and one another, rather than on managing the environment itself. In other words, there is growing recognition that what is required is not the balancing of the economic and social needs of various human stakeholders on the one hand with an acceptable degree of environmental protection on the other, but rather on improving the equity and efficiency of human uses of coastal environments within the limits established by nature. The decline of fisheries in European Union waters to the point where no cod quotas were issued for the 2003 fishing season, provides a clear illustration of the dangers inherent in consistently allocating higher quotas (for socio-economic and economic reasons) that exceeded the natural ability of the ecosystem to regenerate those fish stocks. One of the crucial challenges of the next decade will undoubtedly be to see the extent to which states are willing to severely restrict human uses of the coastal environment in order to ensure that ecological limits are not exceeded, even though this may be politically controversial in the short term.

\subsubsection{Integration with Oceans Management}

Much ICM literature and the focus of most ICM legislation has tended to be on the landward boundary of the coastal zone. There are good reasons for this, particularly from a legal perspective, since many of the difficulties inherent in implementing ICM legislation arise from defining the terrestrial boundaries of coastal areas, and imposing restrictions on human activities within these areas. However, in some countries more attention is now being given to oceans management, influenced partially by the development of international fisheries laws. It seems likely that during the next decade, ICM legislation may begin to place greater emphasis on the marine aspects. Indeed, Canada's Oceans Act already envisages a degree of integration between oceans management and the management of coastal areas. 


\subsubsection{Influence of ICM on Environmental Law}

The recognition of the importance of adopting a holistic and integrated approach to managing human activities within a particular area probably came to the fore first in relation to coastal areas because of the co-incidence of intense human activity and particularly important ecosystems. However, these key insights are also applicable to the management of human activities that impact on other environments. As environmental laws at the international, regional and national law levels develop, recognition of the importance of adopting a holistic and integrated approach that recognizes the inherent nature of ecosystems has emerged in different areas. One example is the ecosystem approach (see Annex 1). It is likely that the relatively well developed principles of ICM will in future influence the development of governance systems for other ecosystems such as the basin approach to the management of water courses.

\subsection{Overview and Conclusions}

This publication has advocated that countries that wish to establish or strengthen national legal frameworks for integrated coastal management, should:

1. take care to understand the issues thoroughly and the rationale for the ICM approach (chapter 1);

2. articulate the principles underlying the national ICM approach, and in doing so, take account of relevant international principles and the experience of other countries (chapters 2 and 3);

3. pay particular attention to the process used to introduce or reform the legal and institutional framework for ICM as this will have a profound effect on the outcome, including the extent to which ICM laws will be complied with (see chapter 4);

4. analyse the functioning of existing laws and institutions thoroughly before proposing changes (see section 4.4);

5. formulate the legal principles to support ICM and choose appropriate legal techniques to give effect to these principles by considering the inherent qualities of the coast (see Box 9), and with reference to the ICM principles that have been articulated (see sections 2.2, 4.3 and 7.2); allow for a combination of legal techniques to be used to 
achieve ICM objectives, and seek to establish a regulatory system that is flexible enough to deal with the diversity of circumstances found in coastal areas, and that is integrated, transparent and participatory); and

6. pay particular attention to ways of encouraging compliance with ICM legislation and facilitating enforcement (chapter 11) and give consideration to institutional issues, as these will have a decisive influence on the functioning of ICM legislation (see chapter 12).

It is not possible, nor desirable, to set out a generic approach that will be the optimal approach in each country. Accordingly, nothing in this publication should be regarded as prescriptive. The intention of the recommendations in this publication is to alert those involved in developing ICM legislation of issues that should be considered and to provide information about different ways in which these can be addressed. It is hoped that this will facilitate more informed decision-making and will make it easier for countries to establish and strengthen their legal and institutional frameworks for ICM. However, each system will be different and must be shaped by the particular circumstances of the country concerned. 
ANNEXES 


\section{ANNEX 1}

\section{THE ECOSYSTEM APPROACH}

(Decision V/6 of the $5^{\text {th }}$ meeting of the Conference of the Parties to the Convention on Biological Diversity)

\section{The Conference of the Parties,}

1. Endorses the description of the ecosystem approach and operational guidance contained in sections $\mathrm{A}$ and $\mathrm{C}$ of the Annex to the present decision, recommends the application of the principles contained in section $\mathrm{B}$ of the Annex, as reflecting the present level of common understanding, and encourages further conceptual elaboration, and practical verification;

\section{A. Description of the ecosystem approach}

1. The ecosystem approach is a strategy for the integrated management of land, water and living resources that promotes conservation and sustainable use in an equitable way. Thus, the application of the ecosystem approach will help to reach a balance of the three objectives of the Convention: conservation; sustainable use; and the fair and equitable sharing of the benefits arising out of the utilization of genetic resources.

2. An ecosystem approach is based on the application of appropriate scientific methodologies focused on levels of biological organization, which encompass the essential structure, processes, functions and interactions among organisms and their environment. It recognizes that humans, with their cultural diversity, are an integral component of many ecosystems.

3. This focus on structure, processes, functions and interactions is consistent with the definition of "ecosystem" provided in Article 2 of the Convention on Biological Diversity: "Ecosystem" means a dynamic complex of plant, animal and micro-organism communities and their non-living environment interacting as a functional unit." This definition does not specify any particular spatial unit or scale, in contrast to the Convention definition of "habitat". Thus, the term "ecosystem" does not, necessarily, correspond to the terms "biome" or "ecological zone", but can refer to any functioning unit at any scale. Indeed, the scale of analysis and action should be determined by the problem being addressed. It could, for example, be a grain of soil, a pond, a forest, a biome or the entire biosphere. 
4. The ecosystem approach requires adaptive management to deal with the complex and dynamic nature of ecosystems and the absence of complete knowledge or understanding of their functioning. Ecosystem processes are often non-linear, and the outcome of such processes often shows time-lags. The result is discontinuities, leading to surprise and uncertainty. Management must be adaptive in order to be able to respond to such uncertainties and contain elements of "learning-by-doing" or research feedback. Measures may need to be taken even when some cause-and-effect relationships are not yet fully established scientifically.

5. The ecosystem approach does not preclude other management and conservation approaches, such as biosphere reserves, protected areas, and single-species conservation programmes, as well as other approaches carried out under existing national policy and legislative frameworks, but could, rather, integrate all these approaches and other methodologies to deal with complex situations. There is no single way to implement the ecosystem approach, as it depends on local, provincial, national, regional or global conditions. Indeed, there are many ways in which ecosystem approaches may be used as the framework for delivering the objectives of the Convention in practice.

\section{B. Principles of the ecosystem approach}

The following 12 principles are complementary and interlinked:

Principle 1 - The objectives of management of land, water and living resources are a matter of societal choice.

Rationale: Different sectors of society view ecosystems in terms of their own economic, cultural and societal needs. Indigenous peoples and other local communities living on the land are important stakeholders and their rights and interests should be recognized. Both cultural and biological diversity are central components of the ecosystem approach, and management should take this into account. Societal choices should be expressed as clearly as possible. Ecosystems should be managed for their intrinsic values and for the tangible or intangible benefits for humans, in a fair and equitable way.

Principle 2 - Management should be decentralized to the lowest appropriate level.

Rationale: Decentralized systems may lead to greater efficiency, effectiveness and equity. Management should involve all stakeholders and 
balance local interests with the wider public interest. The closer management is to the ecosystem, the greater the responsibility, ownership, accountability, participation, and use of local knowledge.

Principle 3 - Ecosystem managers should consider the effects (actual or potential) of their activities on adjacent and other ecosystems.

Rationale: Management interventions in ecosystems often have unknown or unpredictable effects on other ecosystems; therefore, possible impacts need careful consideration and analysis. This may require new arrangements or ways of organization for institutions involved in decision-making to make, if necessary, appropriate compromises.

Principle 4 - Recognizing potential gains from management, there is usually a need to understand and manage the ecosystem in an economic context. Any such ecosystem-management programme should:

(a) Reduce those market distortions that adversely affect biological diversity;

(b) Align incentives to promote biodiversity conservation and sustainable use;

(c) Internalize costs and benefits in the given ecosystem to the extent feasible.

Rationale: The greatest threat to biological diversity lies in its replacement by alternative systems of land use. This often arises through market distortions, which undervalue natural systems and populations and provide perverse incentives and subsidies to favour the conversion of land to less diverse systems.

Often those who benefit from conservation do not pay the costs associated with conservation and, similarly, those who generate environmental costs (e.g. pollution) escape responsibility. Alignment of incentives allows those who control the resource to benefit and ensures that those who generate environmental costs will pay

Principle 5 - Conservation of ecosystem structure and functioning, in order to maintain ecosystem services, should be a priority target of the ecosystem approach.

Rationale: Ecosystem functioning and resilience depends on a dynamic relationship within species, among species and between species and their abiotic environment, as well as the physical and chemical interactions within 
the environment. The conservation and, where appropriate, restoration of these interactions and processes is of greater significance for the long-term maintenance of biological diversity than simply protection of species.

Principle 6 - Ecosystems must be managed within the limits of their functioning.

Rationale: In considering the likelihood or ease of attaining the management objectives, attention should be given to the environmental conditions that limit natural productivity, ecosystem structure, functioning and diversity. The limits to ecosystem functioning may be affected to different degrees by temporary, unpredictable or artificially maintained conditions and, accordingly, management should be appropriately cautious.

Principle 7 - The ecosystem approach should be undertaken at the appropriate spatial and temporal scales.

Rationale: The approach should be bounded by spatial and temporal scales that are appropriate to the objectives. Boundaries for management will be defined operationally by users, managers, scientists and indigenous and local peoples. Connectivity between areas should be promoted where necessary. The ecosystem approach is based upon the hierarchical nature of biological diversity characterized by the interaction and integration of genes, species and ecosystems.

Principle 8: Recognizing the varying temporal scales and lag-effects that characterize ecosystem processes, objectives for ecosystem management should be set for the long term.

Rationale: Ecosystem processes are characterized by varying temporal scales and lag-effects. This inherently conflicts with the tendency of humans to favour short-term gains and immediate benefits over future ones.

Principle 9 - Management must recognize that change is inevitable.

Rationale: Ecosystems change, including species composition and population abundance. Hence, management should adapt to the changes. Apart from their inherent dynamics of change, ecosystems are beset by a complex of uncertainties and potential "surprises" in the human, biological and environmental realms. Traditional disturbance regimes may be important for ecosystem structure and functioning, and may need to be maintained or restored. The ecosystem approach must utilize adaptive management in order to anticipate and cater for such changes and events and should be cautious in making any decision that may foreclose options, but, at the same 
time, consider mitigating actions to cope with long-term changes such as climate change

Principle 10 - The ecosystem approach should seek the appropriate balance between, and integration of, conservation and use of biological diversity.

Rationale: Biological diversity is critical both for its intrinsic value and because of the key role it plays in providing the ecosystem and other services upon which we all ultimately depend. There has been a tendency in the past to manage components of biological diversity either as protected or nonprotected. There is a need for a shift to more flexible situations, where conservation and use are seen in context and the full range of measures is applied in a continuum from strictly protected to human-made ecosystems.

Principle 11 - The ecosystem approach should consider all forms of relevant information, including scientific and indigenous and local knowledge, innovations and practices.

Rationale: Information from all sources is critical to arriving at effective ecosystem management strategies. A much better knowledge of ecosystem functions and the impact of human use is desirable. All relevant information from any concerned area should be shared with all stakeholders and actors, taking into account, inter alia, any decision to be taken under Article $8(\mathrm{j})$ of the Convention on Biological Diversity. Assumptions behind proposed management decisions should be made explicit and checked against available knowledge and views of stakeholders.

Principle 12 - The ecosystem approach should involve all relevant sectors of society and scientific disciplines.

Rationale: Most problems of biological-diversity management are complex, with many interactions, side-effects and implications, and therefore should involve the necessary expertise and stakeholders at the local, national, regional and international level, as appropriate.

\section{Operational guidance for application of the ecosystem approach}

In applying the 12 principles of the ecosystem approach, the following five points are proposed as operational guidance. 


\section{Focus on the functional relationships and processes within ecosystems}

The many components of biodiversity control the stores and flows of energy, water and nutrients within ecosystems, and provide resistance to major perturbations. A much better knowledge of ecosystem functions and structure, and the roles of the components of biological diversity in ecosystems, is required, especially to understand: (i) ecosystem resilience and the effects of biodiversity loss (species and genetic levels) and habitat fragmentation; (ii) underlying causes of biodiversity loss; and (iii) determinants of local biological diversity in management decisions. Functional biodiversity in ecosystems provides many goods and services of economic and social importance. While there is a need to accelerate efforts to gain new knowledge about functional biodiversity, ecosystem management has to be carried out even in the absence of such knowledge. The ecosystem approach can facilitate practical management by ecosystem managers (whether local communities or national policy makers).

\section{Enhance benefit-sharing}

Benefits that flow from the array of functions provided by biological diversity at the ecosystem level provide the basis of human environmental security and sustainability. The ecosystem approach seeks that the benefits derived from these functions are maintained or restored. In particular, these functions should benefit the stakeholders responsible for their production and management. This requires, inter alia: capacity-building, especially at the level of local communities managing biological diversity in ecosystems; the proper valuation of ecosystem goods and services; the removal of perverse incentives that devalue ecosystem goods and services; and, consistent with the provisions of the Convention on Biological Diversity, where appropriate, their replacement with local incentives for good management practices.

\section{Use adaptive management practices}

Ecosystem processes and functions are complex and variable. Their level of uncertainty is increased by the interaction with social constructs, which need to be better understood. Therefore, ecosystem management must involve a learning process, which helps to adapt methodologies and practices to the ways in which these systems are being managed and monitored. Implementation programmes should be designed to adjust to the unexpected, rather than to act on the basis of a belief in certainties. Ecosystem management needs to recognize the diversity of social and cultural factors affecting natural-resource use. Similarly, there is a need for 
flexibility in policy-making and implementation. Long-term, inflexible decisions are likely to be inadequate or even destructive. Ecosystem management should be envisaged as a long-term experiment that builds on its results as it progresses. This "learning-by-doing" will also serve as an important source of information to gain knowledge of how best to monitor the results of management and evaluate whether established goals are being attained. In this respect, it would be desirable to establish or strengthen capacities of Parties for monitoring.

4. Carry out management actions at the scale appropriate for the issue being addressed, with decentralization to lowest level, as appropriate

As noted in section A above, an ecosystem is a functioning unit that can operate at any scale, depending upon the problem or issue being addressed. This understanding should define the appropriate level for management decisions and actions. Often, this approach will imply decentralization to the level of local communities. Effective decentralization requires proper empowerment, which implies that the stakeholder both has the opportunity to assume responsibility and the capacity to carry out the appropriate action, and needs to be supported by enabling policy and legislative frameworks. Where common property resources are involved, the most appropriate scale for management decisions and actions would necessarily be large enough to encompass the effects of practices by all the relevant stakeholders. Appropriate institutions would be required for such decision-making and, where necessary, for conflict resolution. Some problems and issues may require action at still higher levels, through, for example, transboundary cooperation, or even cooperation at global levels.

\section{Ensure intersectoral cooperation}

As the primary framework of action to be taken under the Convention, the ecosystem approach should be fully taken into account in developing and reviewing national biodiversity strategies and action plans. There is also a need to integrate the ecosystem approach into agriculture, fisheries, forestry and other production systems that have an effect on biodiversity. Management of natural resources, according to the ecosystem approach, calls for increased intersectoral communication and cooperation at a range of levels (government ministries, management agencies, etc.). This might be promoted through, for example, the formation of inter-ministerial bodies within the Government or the creation of networks for sharing information and experience. 


\section{ANNEX 2 \\ SELECTED NON-BINDING INTERNATIONAL ENDORSEMENTS FOR THE NATIONAL ADOPTION OF ICM}

\section{Agenda 21 - Chapter 17 (1992)}

Article 17.1. "the protection and sustainable development of the marine and coastal environment and its resources ... requires new approaches to marine and coastal area management and development, at the national, subregional, regional and global levels, approaches that are integrated in content and precautionary and anticipatory in ambit, as reflected in the following programme areas:

Integrated management and sustainable development of coastal areas, including exclusive economic zones;"

A central objective expressed in Article 17.5 is that:

"Coastal States commit themselves to integrated management and sustainable development of coastal areas and the marine environment under their national jurisdiction."

In recommending activities to achieve this objective, Article 17.6 provides that:

"Each coastal State should consider establishing, or where necessary strengthening, appropriate coordinating mechanisms (such as a high-level policy planning body) for integrated management and sustainable development of coastal and marine areas and their resources, at both the local and national levels."

\section{The Jakarta Mandate}

(Decision II/10 of the Conference of the parties to the Convention on Biological Diversity: "Conservation and Sustainable Use of Marine and Coastal Biological Diversity")

"The conference of the Parties ...

encourages the use of integrated marine and coastal area management as the most suitable framework for addressing human impacts on marine and coastal biological diversity and for promoting conservation and sustainable use of this biodiversity;

encourages Parties to establish and/or strengthen, where appropriate, institutional, administrative and legislative arrangements for the development 
of integrated management of marine and coastal eco-systems, plans and strategies for marine and coastal areas, and their integration with national development plans;"

\section{Code of Conduct for Responsible Fisheries}

\section{Article 10.1 Institutional Framework}

"States should ensure that an appropriate policy, legal and institutional framework is adopted to achieve the sustainable and integrated use of the resources, taking into account the fragility of coastal ecosystems and the finite nature of their natural resources and the needs of coastal communities."

"10.1.3. States should develop, as appropriate, institutional and legal frameworks in order to determine the possible uses of coastal resources and to govern access to them, taking into account the rights of coastal fishing communities and their customary practices to the extent compatible with sustainable development."

Johannesburg Plan of Implementation (World Summit on Sustainable Development, 2002)

Paragraph 30 provides that:

"Ensuring the sustainable development of the oceans requires effective coordination and cooperation ... to: ...

(a) Promote the implementation of Chapter 17 of Agenda 21, which provides the programme of action for achieving the sustainable development of oceans, coastal areas and seas through its programme areas of integrated management and sustainable development of coastal areas, including exclusive economic zones; marine environmental protection; sustainable use and conservation of marine living resources; addressing critical uncertainties for the management of the marine environment and climate change; strengthening international, including regional, cooperation and coordination; and sustainable development of small islands;

$\cdots$

(c) Encourage the application by 2010 of the ecosystem approach, noting the Reykjavik Declaration on Responsible Fisheries in the Marine 
Ecosystem $^{335}$ and decision V/6 of the Conference of the Parties to the Convention on Biological Diversity; 336

(d) Promote integrated, multi-disciplinary and multi-sectoral coastal and ocean management at the national level and encourage and assist coastal States in developing ocean policies and mechanisms on integrated coastal management;

\section{$\cdots$}

(g) Assist developing countries in coordinating policies and programmes at the regional and sub-regional levels aimed at the conservation and sustainable management of fishery resources and implement integrated coastal area management plans, including through the promotion of sustainable coastal and small-scale fishing activities and, where appropriate, the development of related infrastructure ... "

Paragraph 32 provides that States should:

"(b) Implement the work programme arising from the Jakarta Mandate on the Conservation and Sustainable Use of Marine and Coastal Biological Diversity of the Convention on Biological Diversity, ${ }^{337}$ including through the urgent mobilization of financial resources and technological assistance and the development of human and institutional capacity, particularly in developing countries;

(d) Develop and facilitate the use of diverse approaches and tools, including the ecosystem approach, the elimination of destructive fishing practices, the establishment of marine protected areas consistent with international law and based on scientific information, including representative networks by 2012 and time/area closures for the protection of nursery grounds and periods, proper coastal land use and watershed planning and the integration of marine and coastal areas management into key sectors ..."

335 See Food and Agriculture Organization of the United Nations document C200/INF/25, Appendix I.

336 See UNEP/CBD/COP/5/23, Annex III.

337 See A/51/312 Annex II, Decision II/10. 


\section{ANNEX 3 \\ THE PROCESS OF DEVELOPING A CONSENSUS BASED COASTAL MANAGEMENT POLICY IN SOUTH AFRICA}

\section{Recognizing the need for a policy to control coastal development}

In 1982 a Council for the Environment was established to advise the Minister of Environmental Affairs on environmental matters. The council established a Committee for Coastal and Marine Systems (CCMS) comprised mainly of members from academia and government. The CCMS approached coastal management from the perspective of the natural sciences and developed principles, objectives and guidelines focussing on the need to avoid development in ecologically sensitive and high-risk coastal areas. However, little attention was given to the socio-economic and political dimensions of coastal management, there was little or no public participation in the policy formulation process and the emphasis was on "top down" regulatory mechanisms to control development.

\section{Shifting to a more holistic approach}

In the early 1990s a new approach to coastal management began to emerge in the environmental of political transition following the end of bans on organizations in 1990 and the lead up to the first democratic elections in 1994. It was recognized that a new approach to coastal management had to be based on real public participation and to address the political, social and economic realities of South Africa, as well as ecological issues. Consultants were appointed to advise on how to proceed with the new approach to policy formulation and the following key steps were identified in the process:

- identify coastal stakeholders;

- jointly design the policy formulation process with stakeholders and agree on the procedures and rules to be adopted in formulating a policy;

- create a climate that was conducive to effective and ongoing participation by stakeholders;

- collectively identify key issues, principles, goals and objectives for coastal management in order to develop a common understanding of coastal issues; 
- evaluate the financial, administrative and other implications of alternative options for implementing the policy; and

- agree on the optimal policy in the light of the assessment of the practical implications.

It was recognized that in order for this approach to succeed it would be necessary for the process to be an open voluntary one founded on democratic principles, that the process should be publicly accountable, be based on open, honest sharing of information and views amongst stakeholders, and result in a coastal policy that was capable of implementation and relevant to the needs of the coastal stakeholders. Based on the recommendations of the consultants, the Department of Environmental Affairs (DEA) decided to embark on a coastal management policy programme (CMPP) over a five-year period. During the first two years the focus was on securing support across the political spectrum (which was very volatile at the time). This was seen as of fundamental importance to securing public and political endorsement for the outcomes of the process. During this period a wide number of interest groups were consulted including national, provincial and local government bodies, organizations involved in the liberation struggle, trade unions, community based organizations, organized business groups, parastatals and environmental NGOs. The consultations during this period produced a consensus on a number of important issues related to the process to be followed.

It was agreed that a coastal policy was needed but that the process should focus initially on agreeing on an appropriate policy formulation process before discussing the substantive content of the policy.

The process must involve and build the capacity of public and coastal stakeholders.

The process should be overseen by an independent policy committee with representatives of both government and civil society that was accountable to the Minister responsible for environmental matters. The policy committee would have five government members (one from national government and one from each of the four coastal provinces); and five members of civil society representing business, labour, community-based organizations, environmental NGOs and the sport and recreational sector. There would be 
a neutral and independent chairperson and each of the members would have equal status and decisions should be made by consensus.

The policy formulation process must be followed by a phase of implementation.

After the Minister endorsed the process an interim project management team was put in place and the foundations for initiating the process (e.g. securing donor funding) were put in place. This was followed by an inception phase during which the policy committee was constituted as an independent nonprofit organization, and the policy committee then approved a project guide document which recorded the main agreements reached during the initial consultation process and established the fundamental principles by which the policy formulation process should be guided. The guiding principles and rules established in the project guide were then translated into a work programme and budget. The work programme and budget established four goals, identified as a series of stages to be followed, and identified the main activities of the programme while establishing the process for approving activities and expenditure.

The four goals were:

(1) to promote meaningful participation by coastal stakeholders and to create a commitment among them to the policy and its implementation;

(2) to develop a policy with scientific integrity;

(3) to promote integrated coastal management based on a partnership between government, civil society and the private sector; and

(4) to develop a practical policy that focussed on priority issues and the introduction of practical measures to implement the policy effectively.

These goals not only guided the CMPP process, but also provided a yardstick for evaluating its success and for identifying lessons to improve future practise.

Four key stages were identified:

(a) firstly, identifying coastal issues and defining a vision for the coast;

(b) generating policy options that identified a desired policy objective, the actors that would be involved in achieving it and the practical actions that would be required to address the issue of concern; 
(c) assessment of the implications of the different policy options; and

(d) selection of preferred policy options based on a consideration of the implications.

The stages in the formulation and adoption of the coastal policy were as follows:

- programme development;

- programme initiation (six months);

- identification of issues and visions for thirteen coastal regions (based on the results of 22 regional workshops);

- extensive interviews and capacity building session followed by a national workshop (four months);

- generation of policy options based on more than fifty workshops and meetings with sectoral interest groups (e.g. environmental NGOs, labour, etc.) in the regions (three months).

Glavovic draws attention to the fact that a critical shift in thinking occurred at this point, influenced by inputs from the international members of the team. Prior to that, the thinking had been heavily influenced by the historical focus on minimizing threats to coastal ecosystems by controlling development. The needs and issues expressed by stakeholders resulted in a shift towards what has been described as a more "people-centred strategic perspective" and the importance of considering the protection of coastal ecosystems not so much as a conservation issue, but rather as an integral part of the pursuit of sustainable development. It is also significant that at midpoint in the process the CMPP identified a number of factors which they considered to be critical to the successful outcome of the process. They concluded that the policy should include a national statement of political intent that committed participants to an integrated coastal management approach (securing evidence of the economic and political value of the coast was seen as crucial to securing the necessary political buy-in). Secondly, the policy must articulate a vision, principles, goals and objectives for coastal management in order to establish a normative framework. Thirdly, it was essential to prepare a plan of action that provided clear direction for taking measures to address priority issues that are uniquely coastal in nature (rather than addressing all issues of concern). During this phase, the specialist studies were concluded. 


\section{Policy option assessment (three months)}

This process is carried out primarily by the project management team assisted by specialists from the government, private sector, NGOs and CDOs. This process resulted in a government discussion paper (Green Paper) which not only assessed and presented policy options but was also intended to inform the public about the coast and coastal management issues.

\section{Selecting policy options (three months)}

Regional meetings and workshops with stakeholders were held during this period to identify preferred policy options. The response from stakeholders emphasized support for the central themes of the Green Paper and of the vision, principles, goals and objectives outlined in it. Interestingly, the Green Paper had presented three alternative institutional models for implementing the policy and had asked stakeholders to identify the model, or combination of models, that would be most appropriate. However, stakeholders responded by emphasising that rather than choosing a particular model for implementation, implementation should be seen as a process which would allow for incremental institutional change (which may vary in pace and nature between regions) with particular emphasis on a cooperative approach that fostered partnerships between government, the private sector and civil society. However, there was strong support for the introduction of a specific coastal management Act to address the shortcomings of exiting legal framework. Stakeholders also indicated a preference for a decentralised approach to coastal management.

\section{Preparation of draft Government Policy (White Paper)}

It had been envisaged that there would be a final round of regional and provincial workshops which would culminate in a national policy conference to determine coastal policy which was to be reflected in a draft White Paper to be presented to the government for endorsement. However, during this stage government strongly asserted its responsibility for finalising the White Paper and moving it through formal government channels in order for it to become official government policy. Public workshops were curtailed and the draft White Paper was prepared collaboratively between the CMPP team and officials from national and provincial government. During this period ownership of the policy effectively passed from the policy committee to the Department of Environmental Affairs and Tourism. The draft White Paper was then distributed and information sessions were held with stakeholders to 
Integrated coastal management, "ICM", is widely accepted throughout the world as the best approach to dealing with coastal issues. The 1990s saw a proliferation of legislative reform processes throughout the world. This aimed at supporting the implementation of ICM. Despite many international environmental treaties, declarations and other promises of action, the quality of coastal environments continues to deteriorate while the demand for coastal resources has increased in most of the world. This publication, in its practical guidance, will be especially valuable to anyone involved in the development, drafting or implementation of a legal or institutional framework to promote ICM. It is enhanced by illustrative examples of a range of countries throughout the world which are at various stages of developing and implementing legislation to promote ICM. 
explain and to encourage them to provide written feedback. These responses were then collated and taken into account in finalizing the White Paper. The cabinet approved the amended White Paper on 1 December 1999 and six months later the official White Paper was publicly released.

\section{Implementation}

Following the release of the White Paper, at the institutional level there was the formation and strengthening of provincial coastal committees and specialist studies were commissioned to identify appropriate legal reforms to facilitate the implementation of the White Paper. The government eventually decided to draft a framework Coastal Management Act that was consistent with the framework National Environmental Management Act. This repealed the 1926 Sea-shore Act and the Control of Dumping at Sea Act. No public participation was permitted during the preparation of drafts of the new Act on the grounds of efficiency and on the basis that it was simply implementing policy objectives arrived at through public consultation. However, there was consultation through existing structures with other central government departments and with provincial governments.

In any event, the Bill was not completed and according to its Web site, the Marine and Coastal Management Branch of the Department of Environmental Affairs and Tourism "is currently drafting legislation to manage our coastal zone in an integrated way" 338 A later posting lists the "Draft Coastal Zone Management Bill", but the text is not linked nor is its status indicated. 339

338 Available at www.mcm-deat.gov.za (30 June 2006).

339 Available at www.mcm-deat.gov.za (21 September 2006). 